\title{
Copyright
}

by

Ernesto Friedrich de Lima Amaral

2007 
The Dissertation Committee for Ernesto Friedrich de Lima Amaral certifies that this is the approved version of the following dissertation:

\section{Demographic Change and Economic Development at the Local Level in Brazil}

\section{Committee:}

Joseph E. Potter, Supervisor

Daniel S. Hamermesh

Thomas W. Pullum

Bryan R. Roberts

Andrés Villarreal 


\title{
Demographic Change and Economic Development at the Local Level in Brazil
}

by

Ernesto Friedrich de Lima Amaral, B.A.; M.A.

\author{
Dissertation \\ Presented to the Faculty of the Graduate School of \\ The University of Texas at Austin \\ in Partial Fulfillment \\ of the Requirements \\ for the Degree of
}

Doctor of Philosophy

The University of Texas at Austin

August 2007 


\section{Dedication}

To Mãe, Pai, Janaina, Camilo and Adriane. 


\section{Acknowledgements}

I gratefully acknowledge financial support from the Brazilian Ministry of Education (MEC) through the Coordination for the Improvement of Higher Education Personnel (CAPES), the John D. and Catherine T. MacArthur Foundation, the Population Reference Bureau, and the William and Flora Hewlett Foundation. Daniel Hamermesh, Joseph Potter, Starling Pullum, Thomas Pullum, Eduardo Rios-Neto, Bryan Roberts, Viviana Salinas, Eunice Vargas, Andrés Villarreal and participants at several conferences played an important role in the discussions that led up to this analysis. 


\title{
Demographic Change and Economic Development at the Local Level in Brazil
}

\author{
Publication No. \\ Ernesto Friedrich de Lima Amaral, Ph.D. \\ The University of Texas at Austin, 2007
}

Supervisor: Joseph E. Potter

In this analysis, I estimate the impact of the changing relative size of the adult male population, classified by age and education groups, on the earnings of employed males living in 502 Brazilian local labor markets during four time periods between 1970 and 2000. The effects of shifts in the age distribution of the working age population have been studied in relation to the effect of the baby-boom generation on the earnings of different cohorts in the United States. However, the question has received little attention in the context of the countries in Asia and Latin America, which are now experiencing substantial shifts in their age-education distributions. Taking advantage of the huge variation across Brazilian local labor markets, the models in this research suggest that age-education groups are not perfect substitutes, so that own-cohort-education size depresses earnings, as expected by the theory. Compositional shifts are influential, attesting that this approach represents a fruitful way of studying this central problem in economic development, going beyond the effects normally analyzed by formal labor market equations. 


\section{Table of Contents}

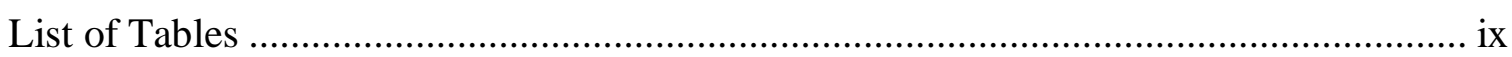

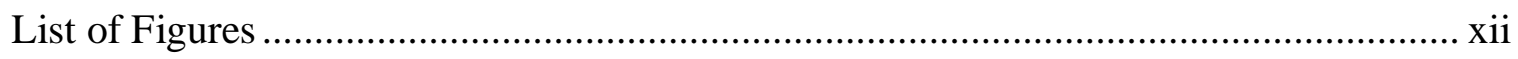

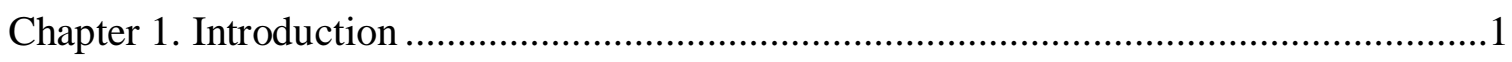

Chapter 2. Demographic dividends and labor demand ....................................................

Population growth and economic development .....................................................

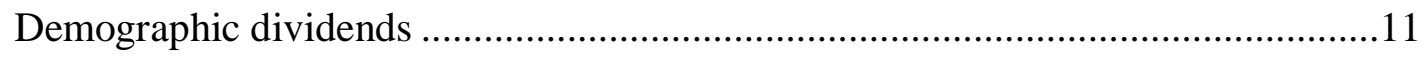

Influence of age, experience and cohort size on earnings .......................................14

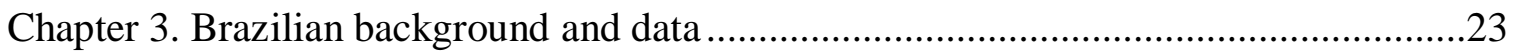

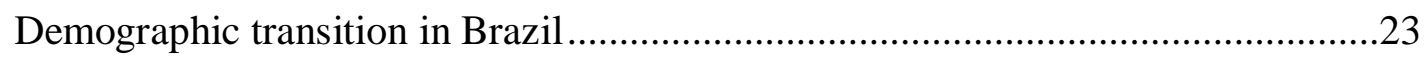

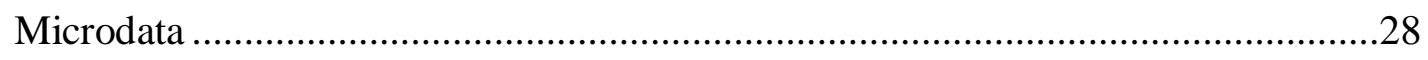

Creating aggregate-level data ..........................................................................

Chapter 4. Formulation of the research design .................................................................42

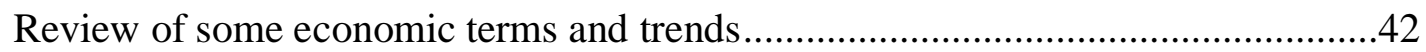

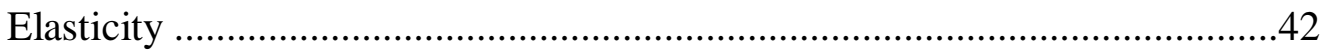

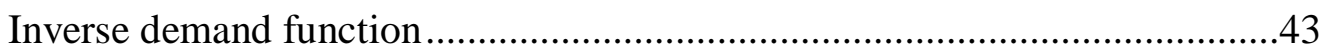

Own- and cross-price elasticities of labor demand \& own- and crossquantity elasticities of factor price ...........................................................45

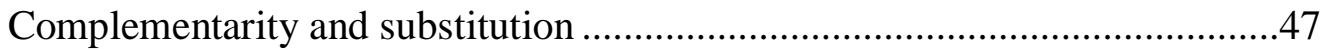

Effects of education and demographic shocks on elasticities of labor demand and factor price ........................................................................48

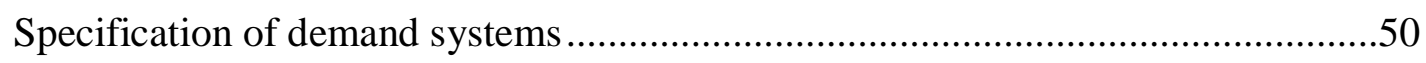

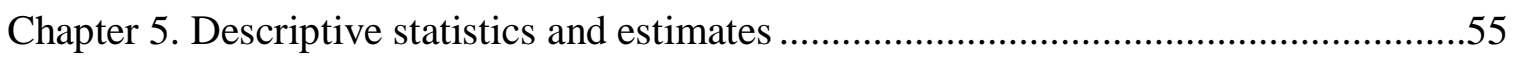

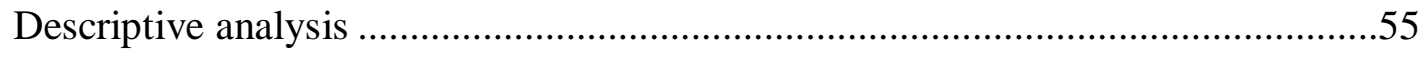

Estimating the effects on labor-market outcomes...................................................73

The influence of Brazilian major regions ...........................................................100

The issue of micro-region size ......................................................................110

Summary of models ...................................................................................122 
Chapter 6. Potential problems on estimated own-quantity elasticities

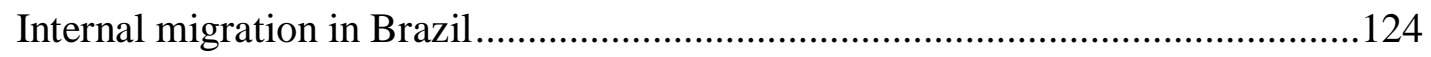

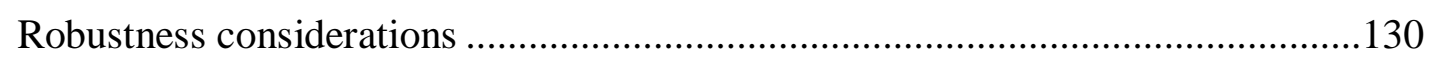

Chapter 7. Implications for public policies ..................................................................134

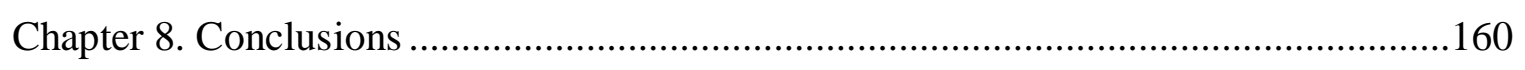

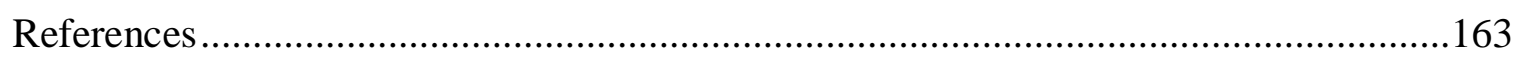

Vita 


\section{List of Tables}

Table 3.1. Total Fertility Rate, Infant Mortality Rate and Life Expectancy at Birth in

Brazil, 1950-2050........

Table 3.2. Distribution of Missing Values of Earnings by Age-Education Group and Year, and Total Number of Observations ${ }^{+}, 1970-2000$.

Table 3.3. Mean Real Monthly Earnings of Male Population by Year and AgeEducation Group, 1970-2000+.....

Table 5.1. Percent of Male Population by Year and Age-Education Group, 19602000

Table 5.2. Fixed-Effects Estimates Including Only Year and Age-Education Indicators, 1970-2000. Dependent Variable is $\log (\text { Monthly Earnings })^{+} \ldots . . .76$

Table 5.3. Fixed-Effects Estimates of Equation (1), 1970-2000. Dependent Variable is $\log (\text { Monthly Earnings })^{+}$ .78

Table 5.4. Fixed-Effects Estimates of Equation (1'), 1970-2000. Dependent Variable is $\log (\text { Monthly Earnings })^{+}$

Table 5.5. Elasticities for Estimates of Equation (1'), Based on the National Age-

Education Distribution of Table 5.1, 1970-2000. Dependent Variable is $\log (\text { Monthly Earnings })^{+}$.

Table 5.6. Fixed-Effects Estimates of Equation (2), 1970-2000. Dependent Variable is $\log (\text { Monthly Earnings })^{+}$

Table 5.7. Variation in Male Population Size Across the Micro-Regions by Year and Age-Education Group, Ages 15-34, 1970-2000+.

Table 5.8. Variation in Male Population Size Across the Micro-Regions by Year and Age-Education Group, Ages 35-64, 1970-2000+. 
Table 5.9. Summary of F-Statistics from the Model Only With Age-Education-Group and Year Indicators, from Equations (1), (1'), (2), (2'), and from Models Including Interactions With Micro-region Size and Region Indicators......123

Table 7.1. Effects of Age and Education Distributions on Predicted Earnings ${ }^{+}$from Equation (1) by Age-Education Groups, 1970 and 2000

Table 7.2. Effects of Age and Education Distributions on Predicted Earnings ${ }^{+}$from Equation (1') by Age-Education Groups, 1970 and 2000.

Table 7.3. Gini Coefficient Calculation Using Predicted National Earnings ${ }^{+}$from Equation (1) and National Age-Education Distribution, 1970.

Table 7.4. Gini Coefficient Calculation Using Predicted National Earnings ${ }^{+}$from Equation (1) and National Age-Education Distribution, 2000.

Table 7.5. Gini Coefficient Calculation Using Predicted National Earnings ${ }^{+}$from Equation (1) and National Age-Education Distribution, and Maintaining the 1970 Age Distribution Constant, 2000.

Table 7.6. Gini Coefficient Calculation Using Predicted National Earnings ${ }^{+}$from Equation (1) and National Age-Education Distribution, and Maintaining the 1970 Education Distribution Constant, 2000. 150

Table 7.7. Gini Coefficient Calculation Using Predicted National Earnings ${ }^{+}$from Equation (1') and National Age-Education Distribution, 1970.

Table 7.8. Gini Coefficient Calculation Using Predicted National Earnings ${ }^{+}$from Equation (1') and National Age-Education Distribution, 2000. 152

Table 7.9. Gini Coefficient Calculation Using Predicted National Earnings ${ }^{+}$from Equation (1') and National Age-Education Distribution, and Maintaining the 1970 Age Distribution Constant, 2000. 
Table 7.10. Gini Coefficient Calculation Using Predicted National Earnings ${ }^{+}$from Equation (1') and National Age-Education Distribution, and Maintaining the 1970 Education Distribution Constant, 2000.

Table 7.11. Summary of Gini Coefficients Using Predicted National Earnings from Equations (1) and (1') and National Age-Education Distributions, 1970 and 2000 .

Table 7.12. Percent of Male Population by Year, Race, and Age-Education Group, $1980-2000$

Table 7.13. Mean Real Monthly Earnings of Male Population by Year, Race, and Age-Education Group, 1980-2000+ 


\section{List of Figures}

Figure 3.1. Dependency Ratios in Brazil, 1950-2050.

Figure 5.1. Proportion of Men Ages 15-24 with 0-4 Years of Schooling in 502

Micro-regions, 1970-2000 .56

Figure 5.2. Proportion of Men Ages 15-24 with 5-8 Years of Schooling in 502

Micro-regions, 1970-2000

Figure 5.3. Proportion of Men Ages 15-24 with 9+ Years of Schooling in 502 Microregions, 1970-2000.

Figure 5.4. Proportion of Men Ages 25-34 with 0-4 Years of Schooling in 502

Micro-regions, 1970-2000

Figure 5.5. Proportion of Men Ages 25-34 with 5-8 Years of Schooling in 502

Micro-regions, 1970-2000

Figure 5.6. Proportion of Men Ages 25-34 with 9+ Years of Schooling in 502 Microregions, 1970-2000.

Figure 5.7. Proportion of Men Ages 35-49 with 0-4 Years of Schooling in 502

Micro-regions, 1970-2000

Figure 5.8. Proportion of Men Ages 35-49 with 5-8 Years of Schooling in 502

Micro-regions, 1970-2000

Figure 5.9. Proportion of Men Ages 35-49 with 9+ Years of Schooling in 502 Micro-

regions, 1970-2000.

Figure 5.10. Proportion of Men Ages 50-64 with 0-4 Years of Schooling in 502

Micro-regions, 1970-2000.

Figure 5.11. Proportion of Men Ages 50-64 with 5-8 Years of Schooling in 502

Micro-regions, 1970-2000. 
Figure 5.12. Proportion of Men Ages 50-64 with 9+ Years of Schooling in 502

Micro-regions, 1970-2000

Figure 5.13. Changes in the Age Distribution in Selected Micro-regions (Northeast), 1970 and 2000.

Figure 5.14. Changes in the Age Distribution in Selected Micro-regions (Southeast, South, Center-West), 1970 and 2000.

Figure 5.15. Changes in the Education Distribution in Selected Micro-regions

(Northeast), 1970 and 2000.

Figure 5.16. Changes in the Education Distribution in Selected Micro-regions (Southeast, South, Center-West), 1970 and 2000.

Figure 5.17. Predicted Earnings ${ }^{+}$from Equation (1) by Proportion of Men in AgeEducation Groups for 502 Micro-regions, Men 25-34 with 9+ Years of Schooling, and Men 35-49 with 0-4 Years of Schooling, 1970-2000. .......80

Figure 5.18. Ratios of Predicted Earnings from Equation (1) to Predicted Earnings from Table 5.2, using the National Age-Education Distribution, 19702000 .

Figure 5.19. Ratios of Predicted Earnings from Equation (1') to Predicted Earnings from Table 5.2, using the National Age-Education Distribution, 19702000 .

Figure 5.20. Ratios of Observed Earnings, of Predicted Earnings from Equation (1), and of Predicted Earnings from Equation (1'), to Predicted Earnings from Table 5.2, Males Ages 35-49 with 5-8 Years of Education, 19702000, Selected Micro-regions (Northeast). 
Figure 5.21. Ratios of Observed Earnings, of Predicted Earnings from Equation (1), and of Predicted Earnings from Equation (1'), to Predicted Earnings from Table 5.2, Males Ages 35-49 with 5-8 Years of Education, 19702000, Selected Micro-regions (Southeast, South, Center-West).

Figure 5.22. Ratios of Observed Earnings, of Predicted Earnings from Equation (1), and of Predicted Earnings from Equation (2), to Predicted Earnings from Table 5.2, Males Ages 35-49 with 5-8 Years of Education, 1970-2000, Selected Micro-regions (Northeast).

Figure 5.23. Ratios of Observed Earnings, of Predicted Earnings from Equation (1), and of Predicted Earnings from Equation (2), to Predicted Earnings from Table 5.2, Males Ages 35-49 with 5-8 Years of Education, 1970-2000, Selected Micro-regions (Southeast, South, Center-West).

Figure 5.24. Ratios of Observed Earnings, of Predicted Earnings from Equation (1'), and of Predicted Earnings from Equation (2'), to Predicted Earnings from Table 5.2, Males Ages 35-49 with 5-8 Years of Education, 19702000, Selected Micro-regions (Northeast).

Figure 5.25. Ratios of Observed Earnings, of Predicted Earnings from Equation (1'), and of Predicted Earnings from Equation (2'), to Predicted Earnings from Table 5.2, Males Ages 35-49 with 5-8 Years of Education, 19702000, Selected Micro-regions (Southeast, South, Center-West).

Figure 5.26. Ratios of Observed Earnings, of Predicted Earnings from Equation (2), and of Predicted Earnings from Equation (2'), to Predicted Earnings from Table 5.2, Males Ages 35-49 with 5-8 Years of Education, 19702000, Selected Micro-regions (Northeast). 
Figure 5.27. Ratios of Observed Earnings, of Predicted Earnings from Equation (2), and of Predicted Earnings from Equation (2'), to Predicted Earnings from Table 5.2, Males Ages 35-49 with 5-8 Years of Education, 19702000, Selected Micro-regions (Southeast, South, Center-West).

Figure 5.28. Ratios of Observed Earnings, of Predicted Earnings from Equation (1), and of Predicted Earnings from Equation (1) Including Interactions With Region Indicators, to Predicted Earnings from Table 5.2, Males Ages 35-49 with 5-8 Years of Education, 1970-2000, Selected Micro-regions (Northeast).

Figure 5.29. Ratios of Observed Earnings, of Predicted Earnings from Equation (1), and of Predicted Earnings from Equation (1) Including Interactions With Region Indicators, to Predicted Earnings from Table 5.2, Males Ages 35-49 with 5-8 Years of Education, 1970-2000, Selected Micro-regions (Southeast, South, Center-West).

Figure 5.30. Ratios of Observed Earnings, of Predicted Earnings from Equation (1'), and of Predicted Earnings from Equation (1') Including Interactions With Region Indicators, to Predicted Earnings from Table 5.2, Males Ages 35-49 with 5-8 Years of Education, 1970-2000, Selected Microregions (Northeast)

Figure 5.31. Ratios of Observed Earnings, of Predicted Earnings from Equation (1'), and of Predicted Earnings from Equation (1') Including Interactions With Region Indicators, to Predicted Earnings from Table 5.2, Males Ages 35-49 with 5-8 Years of Education, 1970-2000, Selected Microregions (Southeast, South, Center-West). 
Figure 5.32. Ratios of Observed Earnings, of Predicted Earnings from Equation (2), and of Predicted Earnings from Equation (2) Including Interactions With Region Indicators, to Predicted Earnings from Table 5.2, Males Ages 35-49 with 5-8 Years of Education, 1970-2000, Selected Micro-regions (Northeast).

Figure 5.33. Ratios of Observed Earnings, of Predicted Earnings from Equation (2), and of Predicted Earnings from Equation (2) Including Interactions With Region Indicators, to Predicted Earnings from Table 5.2, Males Ages 35-49 with 5-8 Years of Education, 1970-2000, Selected Micro-regions (Southeast, South, Center-West).

Figure 5.34. Ratios of Observed Earnings, of Predicted Earnings from Equation (2'), and of Predicted Earnings from Equation (2') Including Interactions With Region Indicators, to Predicted Earnings from Table 5.2, Males Ages 35-49 with 5-8 Years of Education, 1970-2000, Selected Microregions (Northeast). 108

Figure 5.35. Ratios of Observed Earnings, of Predicted Earnings from Equation (2'), and of Predicted Earnings from Equation (2') Including Interactions With Region Indicators, to Predicted Earnings from Table 5.2, Males Ages 35-49 with 5-8 Years of Education, 1970-2000, Selected Microregions (Southeast, South, Center-West).

Figure 5.36. Ratios of Observed Earnings, of Predicted Earnings from Equation (1), and of Predicted Earnings from Equation (1) Including Interactions With Micro-region Size, to Predicted Earnings from Table 5.2, Males Ages 35-49 with 5-8 Years of Education, 1970-2000, Selected Micro-regions (Northeast). 
Figure 5.37. Ratios of Observed Earnings, of Predicted Earnings from Equation (1), and of Predicted Earnings from Equation (1) Including Interactions With Micro-region Size, to Predicted Earnings from Table 5.2, Males Ages 35-49 with 5-8 Years of Education, 1970-2000, Selected Micro-regions (Southeast, South, Center-West).

Figure 5.38. Ratios of Observed Earnings, of Predicted Earnings from Equation (1'), and of Predicted Earnings from Equation (1') Including Interactions With Micro-region Size, to Predicted Earnings from Table 5.2, Males Ages 35-49 with 5-8 Years of Education, 1970-2000, Selected Microregions (Northeast).

Figure 5.39. Ratios of Observed Earnings, of Predicted Earnings from Equation (1'), and of Predicted Earnings from Equation (1') Including Interactions With Micro-region Size, to Predicted Earnings from Table 5.2, Males Ages 35-49 with 5-8 Years of Education, 1970-2000, Selected Microregions (Southeast, South, Center-West).

Figure 5.40. Ratios of Observed Earnings, of Predicted Earnings from Equation (2), and of Predicted Earnings from Equation (2) Including Interactions With Micro-region Size, to Predicted Earnings from Table 5.2, Males Ages 35-49 with 5-8 Years of Education, 1970-2000, Selected Micro-regions (Northeast).

Figure 5.41. Ratios of Observed Earnings, of Predicted Earnings from Equation (2), and of Predicted Earnings from Equation (2) Including Interactions With Micro-region Size, to Predicted Earnings from Table 5.2, Males Ages 35-49 with 5-8 Years of Education, 1970-2000, Selected Micro-regions (Southeast, South, Center-West). 
Figure 5.42. Ratios of Observed Earnings, of Predicted Earnings from Equation (2'), and of Predicted Earnings from Equation (2') Including Interactions With Micro-region Size, to Predicted Earnings from Table 5.2, Males Ages 35-49 with 5-8 Years of Education, 1970-2000, Selected Microregions (Northeast).

Figure 5.43. Ratios of Observed Earnings, of Predicted Earnings from Equation (2'), and of Predicted Earnings from Equation (2') Including Interactions With Micro-region Size, to Predicted Earnings from Table 5.2, Males Ages 35-49 with 5-8 Years of Education, 1970-2000, Selected Microregions (Southeast, South, Center-West).

Figure 7.1. Ratios of Predicted Earnings from Equation (1) to Predicted Earnings from Table 5.2, using the National Age-Education Distribution, and Maintaining the 1970 Age Distribution Constant, 1970-2000.

Figure 7.2. Ratios of Predicted Earnings from Equation (1) to Predicted Earnings from Table 5.2, using the National Age-Education Distribution, and Maintaining the 1970 Education Distribution Constant, 1970-2000.

Figure 7.3. Ratios of Predicted Earnings from Equation (1') to Predicted Earnings from Table 5.2, using the National Age-Education Distribution, and Maintaining the 1970 Age Distribution Constant, 1970-2000.

Figure 7.4. Ratios of Predicted Earnings from Equation (1') to Predicted Earnings from Table 5.2, using the National Age-Education Distribution, and Maintaining the 1970 Education Distribution Constant, 1970-2000. 145 


\section{Chapter 1. Introduction}

The substitution of one group of workers for another as their relative supplies change has received substantial attention in the literature on labor demand (Hamermesh 1993, chapter 3). This interest is justified by the importance of the potential effects on wage rates and earnings, and their role in such areas on which economic and social policy might focus; for example old-age assistance benefits, payroll taxes and overall labor productivity. The topic came to the forefront in wealthy countries generally (Bloom et al 1987), and in the United States in particular in the 1970s and 1980s as a result of concerns about the wages of young people after the baby boom of 1946-62 (Freeman 1979; Welch 1979; Berger 1985; Triest et al 2006).

While the impact of demographic change on the structure of wages was shown to be at least temporarily substantial in the United States; and while it has no doubt mattered (probably to a lesser extent) in other rich countries since 1945, wealthy countries may not be the best laboratories in which to examine these impacts. In the United States, the share of the male population ages 15-24 increased from 13.5 percent in 1960 to 19.5 percent in 1980. In Brazil, for example, the rise in longevity and the decline in fertility caused a similar percentage-point drop over two decades, from 37.0 percent in 1980 to 31.7 percent in 2000. Changes in the skill structure of the labor force may be even larger and more rapid: The largest decadal change in the percentage of American men with at least a college education was 6.6 percentage points, between 1970 and 1980. In Brazil between 1991 and 2000 , the percentage of adult men with nine or more years of schooling rose from 20.6 to 29.7 percent. These types of changes in the age and educational structure of the labor force in developing countries may thus provide a greater scope for identifying the impact of 
variations in relative supply on earnings than do the demographic shocks that have occurred in the past half century in richer economies.

Despite the importance of the topic for economic development, and the possible greater variability of the forcing variables in developing countries that would facilitate identification of earnings effects, no studies of developing countries have examined the role of these supply shocks in a formal model of labor demand. Careful research on the significance of changing education and age endowments on wage inequality has been conducted (Gindling and Robbins 2001), and labor demand by firms in Latin America has been examined (e.g., Roberts and Skoufias 1997; Saavedra and Torero 2004); but no study has considered the impact of demographic change in a complete model of labor demand. This study contributes to the literatures on the demographic dividend in developing countries, and to the general study of labor demand, by including cohort size and also the shifting structure of educational attainment in a standard model. Implicitly, the assumption throughout the analysis is that relative supplies of workers classified by age-education are exogenous to the firm, and that firms bid for workers based on their relative scarcity. Using the example of Brazil, the result is a set of estimates of factor-price elasticities by ageeducation group in an economy in which relative supplies of workers are changing rapidly. 


\section{Chapter 2. Demographic dividends and labor demand}

The topic addressed here is related to, but different in its focus from recent studies of the "demographic dividend" whereby the changing age structure in developing countries resulting from sustained and rapid fertility decline presents a temporary "window of opportunity" during which a reduced dependency ratio yields high rates of growth in income per capita. This positive impact on growth derives from the mechanical link between the size of the working age and total population, increases in labor supply due to

higher proportions of women becoming employed, higher savings rates, higher rates of human capital formation, and, possibly, from the impact of population aging on capital accumulation via capital deepening. That the decline in the dependency ratio, caused by rapid fertility decline, has substantially influenced economic development in East and Southeast Asia has been shown often (e.g., Bloom and Freeman 1986; Bloom et al 2003; Williamson 2003; Mason 2005; Mason and Feng 2005). These authors stress the transitory nature of the decrease in the dependency ratio, and as well conditional nature of the dividend: the drop in the dependency ratio will only result in economic growth in the right policy environment.

While the demographic dividend literature focuses on the ratio of the population of working age to the rest of the population, the analysis engaged in this study focuses on the changes in age structure within the population of working age that necessarily accompany the demographic transition, as well as the concurrent change in levels of education that normally accompanies and may even drive the demographic transition. Whereas in the dividend literature, the focus is mainly on aggregated outcomes, the concern is with the distribution of economic outcomes within the labor force and how these may be affected by its changing composition. 
Evidence from studies of the U.S. baby boom has suggested that increases in factor supplies led to the decline in wage rates of the expanding sub-aggregates, confirming the role of negative own-quantity elasticities of factor price. Similarly, one would expect that an increase in the supply of skilled labor will lead to a relative decline in its wage rate. In developed countries, however, this decline has not been observed, with the skill premium increasing along with the supply of educated workers (Katz and Murphy 1992; Autor et al 1998). The reasons may be skill-biased technical change, the role of international trade, or other factors; but the results require expanding the usual production-function framework.

Despite their difficulties in describing aggregate trends over the past three decades, studies of labor-labor substitution in rich countries illustrate the power of a formal factordemand framework. These studies also take advantage of the richness of combining age (experience) and schooling as basic labor inputs, thus driving variations in wage rates. While the technology-constant microeconomic findings are swamped at the macro level by trends arising from aggregate shocks, they support the basic tenets of production theory. Using data at the micro level from a developing country makes it possible to take a formal model and estimate more precisely how changing cohort size and skill alter relative wage differentials.

\section{POPULATION GROWTH AND ECONOMIC DEVELOPMENT}

The debate about the relationship between population growth and economic development has been occurring in the population and reproductive health arena since the 18th and 19th centuries. The first scientific study about the impact of population size on the quality of life was done by Malthus in the classic "An Essay on the Principle of Population" (Malthus 1798). The main idea was that rapid population growth would not be 
followed by an increase in food production, because of fixed resources for agriculture, and slow technical progress. The consequence would be the fall of available diet below subsistence level, to a point that population growth would be stopped by a high mortality rate.

Coale and Hoover (1958) investigated the influence of population changes on the economic development of low-income areas, more specifically India and Mexico. On one hand, this study emphasizes that the:

(...) classic Malthusian argument makes it all too clear that low death rates cannot be maintained long in the absence of profound changes either in the economy (...) or in the birth rate (...). If economic development does not precede the decline in mortality, it must still occur eventually if the decline is to be maintained (Coale and Hoover 1958, p.17).

On the other hand, this research goes beyond the analysis of population growth, highlighting that "the three demographic factors identified as basic in an analysis of the effects of population growth on economic development are population size, rate of population growth, and age-distribution effects." (Coale and Hoover 1958, p.25) In practical terms, the study analyzes the influence of population growth on Indian economic development, using projected populations between 1956 and 1986, and different hypotheses regarding fertility trends. Coale and Hoover indicate that the scenario with higher fertility would not generate a useful working force for Indian society, because "a faster growth rate might simply add to the already large pool of unemployed and underemployed (...) [and] the necessity for devoting much more time to child care would limit the participation of women in the labor force." (Coale and Hoover 1958, p.285)

Kelley (2003) indicates that the analysis of reports written by the United Nations in 1953 and 1973, and the National Academy of Science in 1971 and 1986, is a good source for understanding the debate of population growth and economic development. The author 
argues that the debate was mainly characterized by a division into two different groups, the "traditionalists" and the "revisionists." The first group suggested that population growth is a threat to society, because of the decrease of both the per capita income and the economic growth. These researchers tend to analyze the consequences of population growth using a short-term approach, emphasizing the negative demographic and socioeconomic outcomes that population growth generates. On the other hand, revisionists analyze population growth using a long-term approach. They tend to examine the positive and negative impacts of population growth on demographic and economic variables. Moreover, they analyze how economic and political feedback created by the society and government would influence population growth. Kelley indicates that during the 1950s the revisionist approach was more common in the reports about population growth. During the 1960s and 1970s, the traditionalist approach began to gain significance in those reports, and among the scientific community. However, since the 1980s, the analysis of population growth seems to have revisited the revisionist approach. The difference between those approaches is not directly related to whether population growth is positive or negative. Even revisionists agree that high levels of population growth are not desired by developing or developed countries. The main differences between the approaches of the traditionalists versus the revisionists involves the revisionists emphasis of a long-term analysis, positive and negative outcomes of change in age structure, and the importance of policies and practices implemented by different populations after this change.

Bloom et al (2003) also analyzed the relationship between population change and economic growth. They emphasized that economists and demographers have different interpretations of the subject. Researchers disagree on how economics might be influenced by the population growth, which could restrict, promote or even be independent of economic growth. After World War II, researchers that viewed population growth as a 
restriction to economic development were concerned about the limitations of food supplies and natural resources. Bloom et al indicate that this idea promoted the implementation of family planning programs in developing countries, as a way to control high fertility, and rapid population growth, and as a strategy to reduce the pressure on natural resources, thus improving economic development. This theory that emphasizes the restriction effects of population growth on economic development are based on the writings of Thomas Malthus, who is cited above. More than serving as a pressure on the fixed resources, population growth was also viewed as the source of a negative impact on capital intensity. Rapid population growth would cause reductions in capital per worker and lower living standards, because "when population growth is rapid, a large part of investment is used to supply the needs of the growing population rather than enabling an increase in the level of provision per capita." (Bloom et al 2003, p.13)

The pessimist theory lost its strength over the last 30 years, since the world population doubled and the per capita income increased by three times. Problems related to famines are due to the inequality within developing countries, rather than a shortage of food. Negative effects of population growth were not strongly verified because of improvements in technology, education, health services, and political participation. Because of these new trends, researchers started indicating the positive impacts of population growth, such as the tendency for decline of natural resource prices, due to technological progress. These researchers were not only focusing on the positive impacts of population growth. Their goal was to analyze a wide variety of factors responsible for the consequences of population growth. Bloom et al (2003) indicate that population growth started to be viewed as a phenomenon that could have either positive or negative economic consequences. This new analysis generated a broader discussion of population growth that led to population neutralism as the main line of debate within the demographic community. 
The group Kelley (2003) identifies as revisionist theorists is acknowledged by Bloom et al (2003) as the neutralists. This third theoretical view bases its conclusions on the small, but significant connection found between population growth and economic development:

(...) though countries with rapidly growing populations tend to have more slowly growing economies, this negative correlation typically disappears once other factors such as country size, openness to trade, educational attainment of the population, and the quality of civil and political institutions are taken into account. In other words, when controlling for other factors, there is little crosscountry evidence that population growth impedes or promotes economic growth (Bloom et al 2003, p.17).

Kelley (2003) suggests that at the end of the 1980s there was a consensus among economists about the revisionist theory concerning the relationship between population growth and economic development. Four main areas provide background on revisionist theory: (1) global resource exhaustion was not verified, because of responsiveness of conservation in the face of scarcity, as well as efficacy of markets and political process of distributing resources over time; (2) empirical research did not show a conclusive negative impact of population growth on savings, just as the decline of capital trends did not have a strong impact on economic growth; (3) population growth did not generate a shift in resources from productive physical capital formation to less-productive areas, such as education. The expansion of education enrollments was verified in the context of increases in public spending, reductions in per student expenditures, and efficiency gains in other areas; (4) renewable resource degradation, where property rights are difficult to maintain, was necessary in the face of the concern about population growth effects.

Bloom et al observe that all these theories have been focusing on the influence of population size and growth on economic development, but little attention has been given to the impact of the changing age structure, and how this structure changes when the 
population grows. Bloom et al point out the need to analyze changes in age structure and how it influences economic growth:

(...) economists have tended to focus on population growth, ignoring the changing age distribution within populations as they grow. Yet these changes are arguably as important as population growth. Each age group in a population behaves differently, with distinct economic consequences: The young require intensive investment in health and education, prime-age adults supply labor and savings, and the aged require health care and retirement income. When the relative size of each of these groups in a population changes, so does the relative intensity of these economic behaviors. This matters significantly to a country's income growth prospects. Policymakers with a broad view of development and the complex relation between economic and human development must factor these effects of changing age structure into decisions about their countries' future (Bloom et al 2003, p.20).

In developing countries, mortality and fertility rates started to fall at different levels after the 1950s, characterizing the demographic transition in those areas, where the people in working-age groups were growing proportionally to the dependent population. Because of these factors, those countries have the potential to observe an economic development. However, if the appropriate government policies are not applied, developing countries might experience unemployment, instability, and suffer tensions in the health services, education attainment, and social welfare systems. Developing countries with transitional advantages, such as Southeast Asia and Latin America, have to implement policies to deal with the aging population, as well as take advantage of the remaining years of low dependency ratios (Bloom et al 2003).

In the third chapter of the report presented by the World Bank (2004), the issue of how demographic change will affect the global economy is addressed. The intent is: (1) to identify the main demographic trends currently facing the world; (2) to assess how these trends may affect the global and regional economies; and (3) to discuss policy responses that should be implemented in order to face the challenges posed by demographic change. 
The report suggests that the fertility rate is declining, the life expectancy is improving, the rate of natural population increase is falling, and the elderly dependency ratio is increasing. All these trends indicate that global population growth will continue to slow, the world's population will continue to age, and the proportion of the labor-force population will fall in advanced countries, but increase in many developing countries. Most projected scenarios imply that the increase of the elderly population and the decline of the young population will have a significant impact on economies, specifically in regards to the public pension systems. The effect of demographic change on economics is then addressed by the report:

(...) specifically, per capita growth rates are likely to decline in advanced economies, but rise in those developing countries where the share of the workingage population is increasing. Saving and investment will be affected in all countries, but the countries that are aging faster - Japan and Europe - will experience a deterioration in their current account positions, which will be offset by improvements elsewhere (World Bank 2004, p.154).

Finally, in the discussion dealing with policy responses, the report indicates that in advanced countries the basic aim of these reforms should be to improve labor supply, savings, productivity, and government budget positions, as well as to reduce public debt as a reaction to the aging population. Some specific reforms could involve raising the retirement age and providing pension benefits depending on different levels of life expectancy within a designated area. In developing countries, the main priority is to establish a policy framework to ensure that the potential benefits from the growing working population are maximized, while setting the base for the eventual aging of the population. Governments will have to consolidate adequate and fiscally sustainable pension and health care systems in order to provide a safety net for the elderly. 


\section{DEMOGRAPHIC DIVIDENDS}

The decrease in the dependency ratio caused by rapid fertility decline has been shown to have influenced economic development in the countries of East and Southeast Asia (e.g., Bloom et al 2003; Bloom et al 2000; Bloom and Freeman 1986; Mason 2005; Mason and Feng 2005; Williamson 2003). The focus of those studies was on the shifting age distribution of the populations rather than the rate of population growth. The dependency ratio first increased after the mortality decline at the beginning of the demographic transition, but then fell after fertility began to decrease precipitously in those countries. This process has been called a "demographic dividend" whereby a changing age distribution allows for fewer investments in the youngest cohorts, enabling resources to be allocated for investments in economic development and family welfare. The higher proportion of people in adult age groups is a temporary effect since, after some decades, this population will age and the dependency ratio will again increase. Because of the temporary nature of the dependency ratio decrease, this process has also been called a "window of opportunity" for the implementation of specific policies to generate economic growth.

In the analysis of age structure dynamics and economic growth in Asia, Higgins and Williamson (1997) observe that much of the impressive rise in Asian saving rates since the 1960 s can be explained by the decline in the youth dependency ratio. Wherever the youth dependency burden has decreased dramatically, Asian countries have abandoned their dependence on foreign capital. Much of the contrast in the level of foreign capital dependency in South and East Asia can be explained by the level and trends of the youth dependency ratio.

Researchers deduce that the "window of opportunity" of changing age structure to generate economic development will be utilized in different ways by different countries. 
Some governments will apply polices needed to take advantage of this demographic phenomenon, and others will not. Those countries that do not apply coherent policies to achieve beneficial economic outcomes from this process, will later experience the dilemma of older populations with low socioeconomic status, in a context of high old-dependency ratio.

More than providing a higher proportion of working age population, this context creates the opportunity to improve the standard of living for children, since families have lower fertility, and the resources can be better allocated into the education of infants. At this point, women have greater opportunities to enter the job market, which establishes an increase in the status of women. Moreover, because of lower fertility, parents are better able to improve their savings, which increases the population's ability to generate industrial investments and a better standard of living once reaching older ages. Better health outcomes are also created at this point, because more resources can be applied to the health of infants and parents, including family planning services.

Bloom and Williamson (1998) examined how this process occurred in East Asia. Cross-national analyses were made to show that one third of the economic growth experienced by those countries in the most recent decades was due to the demographic dividend. These authors indicate that some policies had to be applied by governments to take advantage of this process of changing age structure. According to Bloom and Williamson, the education of the younger population has to be prioritized. These policies should include the future low-skilled working-age population that would be more likely to be unemployed. Therefore, public health services have to be made available to the population, addressing both infant care and women's health. Families with a higher income are more likely to be healthy, increasing the pattern of development and economic growth. 
Governments must also implement policies that would generate a diverse variety of jobs, which would allow for more extensive public and private savings within the population.

In a study about China's demographic changes, Mason and Feng (2005) analyze the consequences of new trends in mortality, fertility, population growth rate, age structure, migration and urbanization during the last two and a half decades. They also investigate whether China's economy experienced a "demographic dividend", as well as whether economic development is likely to happen due to future demographic factors. Finally, they identify several social outcomes of China's recent demographic changes. The discussion about the impact of demographic dividend on past, present and future economic trends is the main concept contributed to this specific discussion. Mason and Feng imply that China's first demographic dividend "materialized at the same time that China underwent its most radical economic transitions and faced the strongest unemployment pressures. The demographic factor thus was a favorable factor in China's economic growth during the last quarter century.” (Mason and Feng 2005, p.31)

The notion of a "second dividend" is then used to explain the demographic process that arises due to fluctuations in age structure, which results in an older population, and influences the processes that generate wealth. An initial possibility would be a rapid accumulation of capital, as a consequence of the aging population. The capital-intensity of the economy and the output per worker would rise. This analysis follows a standard neoclassical model that asserts the assumption that the saving rate remains constant.

However, Mason and Feng build their argument around the neo-classical model that considers saving and wealth to be endogenous. Under this assumption, the second possibility is that a rapid increase in the transfer of wealth, rather than capital, would be spawned by the aging population. In this case, wealth comes not with the accumulation of additional capital, but with the growth of transfer wealth. Future generations would provide 
old age support either via public pension plans or familial support systems. It is important to note that increases in capital influence economic growth, but boosts in transfer wealth do not. Lastly, there is a third possibility in which neither transfer nor capital is accumulated, generating even worse standards of livings among the older population.

The level of the second demographic dividend depends on the mechanisms to reallocate resources from surplus ages to deficit ages. Three different forms are available: (1) capital can be accumulated at surplus ages, and later in life the capital can be used at deficit ages; (2) current transfers can be made from surplus ages to deficit ages; (3) credit markets can be used to shift resources to individuals. Moreover, three different institutions are involved in reallocations. Generally, family is the main institution transferring resources across age groups. But the market and the state are also sources of relocating resources to individuals. Mason and Feng emphasize that:

(...) demographic transition has led to more rapid growth in output per capita in many East Asian countries where the demographic transition has been especially rapid. (...) Demographic change offers an opportunity for significantly more rapid economic growth, but only if the policy environment is supportive (Mason and Feng 2005, p.24).

\section{INFLUENCE OF AGE, EXPERIENCE AND COHORT SIZE ON EARNINGS}

The first demographic dividend is determined by the direct impact of the age structure (ratio of working-age population to total population) on per-capita income. Such as discussed above, the decline in the dependency ratio had positive impacts on the economic development of Asian countries that experienced rapid fertility decline. Since this literature is based on the influence of age and education compositions on economic outcomes, it is essential to highlight the contributions made by Mincer (1974) on the connections involving schooling, experience, and earnings. 
One of Mincer's objectives was to estimate the relation between accumulated investments in human capital of workers and their earnings. Moreover, the earnings function was used to determine how the individual differences of investments in human capital can influence inequality in the distribution of labor incomes. Finally, earnings functions helped the understanding of whether earnings structure can be comprehended in terms of human capital investment behavior.

Mincer was concerned about the estimation of earnings functions because previous studies solely utilized the linear impact of years of schooling on log earnings. The observed correlation between education and earnings was not strong in those models, because variations in earnings associated with age were not captured:

Though age can be viewed as an inherent depreciation phenomenon in the human capital terminology, the growth of earnings with age can ultimately be interpreted in the human capital model as being a consequence of net self-investment activities that are continued after the completion of schooling. The theory predicts that investments are concentrated at younger ages, but continue at a diminishing rate throughout much of the working life; because of increasing marginal costs, investments are not made all at once in a short period, but are staggered over time, and decline continuously, both because benefits decline as the payoff period shortens, and because opportunity costs are likely to rise with experience (Mincer 1974, p. 129).

Hence, to expand the schooling model into a more complete earnings function, the linear schooling term must be improved by the use of a nonlinear years-of-experience term:

This function can be applied in multiple regression analysis to earnings data of individuals who differ in both schooling and age. While age is not the same as work experience, the latter can be estimated as actual age minus estimated age at completion of schooling, though direct information on experience is preferable. Clearly, direct information on experience is necessary for specifying earnings functions of individuals whose attachment to the labor force is not continuous (Mincer 1974, p. 129).

The use of experience is most appropriate on studies of female earnings. Studies on male earnings would not be biased if age is used instead of experience, because this group 
is continuously attached to the labor force. The use of both years of schooling and experience as independent variables in earnings functions improve the results, with even better results when weeks worked during the year is included as an explanatory variable.

The choice of expressing earnings in dollars or in logs depends on how information concerning schooling and experience are expressed:

If dollar values are used, the investment variables (schooling and experience) must also be expressed in dollars. If log earnings are used, then the investment variables can be expressed in units of time - years of schooling and years of experience. The time measures of investment are far more readily available than the dollar ones. For both reasons then - interest in relative comparisons and data availability - the logarithmic formulation is preferred (Mincer 1974, p. 130).

Further studies indicate that not only the independent impact of age and education explain earnings, but also cohort size. In other words, the productivity factor (ratio of total income to employment) can be affected by a shift in the population's age structure, generating a second demographic dividend. The productivity component can be exogenously influenced by shifts in the age and educational structures, according to the shape of the labor demand curve for each age and educational labor factor. Studies about influences of changes in age structure on earnings usually focus only on the male labor force trends, partly because these exogenous changes in age structure (fertility decline) and in educational attainment are significantly associated to female labor force participation.

The significance of fertility swings and shifting age distribution on economic development was analyzed in studies of the influence of the "baby boom" on labor market outcomes in the United States (Easterlin 1978; Freeman 1979; Welch 1979). Cohorts born during the "baby boom" entered the American labor market between the end of the 1960s and the middle of the 1970s. The new labor force entrants had more schooling than earlier cohorts: (1) the number of persons with 5-8 years of schooling and with 1-3 years of high 
school fell considerably; (2) the number of high school graduates, and those with at least some college increased significantly.

Easterlin (1978) suggests that the increase in the ratio of younger to older adults after the 1940s in the United States had pervasive socioeconomic implications. Because of this increase, the relative economic position of young adults fell after the 1960s when they entered the labor market. The Easterlin hypothesis implies that these changes in birth rates and cohort size influence trends in demographic and social behavior. More than reducing the economic opportunities of the large cohorts of young adults, this phenomenon results in the decline of fertility rates, the postponement of marriage, higher divorce rates, higher levels of female labor force participation, increasing homicide, suicide and political alienation. As a consequence of a cycle process, the smaller cohorts introduced to the labor market in the 1990s will experience higher relative earnings than other groups, as well as more traditional family structures.

Pampel and Peters (1995) review several studies that tested the Easterlin hypothesis. They examine literature from diverse academic disciplines that offer evidence to support or contradict the different socioeconomic consequences of changing cohort size as suggested by Easterlin. Studies on European countries are also analyzed in order to provide comparative evidence to the U.S. findings, helping to identify the strengths and weaknesses of the theory. Because shifts in gender roles and values may have happened across time and may have changed the application of the theory on recent experiences in comparison to past decades, Pampel and Peters review studies with different temporal scopes. Finally, studies that used different methods are reviewed by the authors, in order to determine whether Easterlin's theory might have a better use in aggregate data or in individual-level studies. The main findings suggest that: 
(...) aggregate data support the hypothesis more than individual-level data, periodspecific or time-series data support the hypothesis more than cohort-specific data, experiences from 1945-1980 support the hypothesis more than the years since 1980, and trends in the United States support the hypothesis more than trends in European nations. Given these data qualifications, the predictions of the Easterlin effect best fit aggregate, period trends from 1945-1980 in the United States. The conceptual broadness of the phenomena potentially explained by the theory represents a strength, but the empirical evidence does not extend as far as the theory suggests (Pampel and Peters 1995, p.189).

As elucidated by Macunovich (1998), the extensive literature on fertility aspects of the Easterlin hypothesis gives support to the theory, but the relationship has been changing across countries and time periods. Macunovich observes that because of data limitations and individual interpretations of the hypothesis, many studies with opposite findings have been weakly related to the Easterlin hypothesis. Simplified interpretations of the hypothesis resulted in a tendency to abandon this theory. These inquiries centered the analysis around the relationship between relative cohort size and fertility, instead of on the relationship between relative income and fertility. Moreover, these interpretations of the Easterlin hypothesis only dealt with the factor of cohort size and did not include other elements that could have an effect on income and fertility trends. Summarizing her analysis, Macunovich indicates that:

In aggregate analyses, studies which find little or no support for the Easterlin hypothesis tend to be those which: [1] use variables which are not age-specific (This is particularly true of the European analyses: none of the aggregate studies of countries outside North America have used age-specific relative income measures); [2] use relative cohort size or relative income variables without any other controls; [3] attempt to fit the Easterlin model with older (age 30+) age groups; [4] treat family income and male earnings as interchangeable; [5] use relative cohort size rather than relative income as the independent variable (especially in later years). In microlevel analysis, studies which find little or no support for the Easterlin hypothesis tend to be those which: [1] treat family income and male earnings as interchangeable; [2] use only the husband's characteristics in formulating relative income variables, without information on his or his wife's parents; [3] focus the analysis only on women in intact first marriages with no 'unwanted' or 'unintended' births, and analyze fertility with 
age at marriage held constant; [4] with categorical rather than continuous measures of relative income, treat the second generation's minimum consumption threshold (i.e. the level of affluence required before they feel able to support a family) as equal to first generation income, rather than a function of it; [5] use expected or desired rather than actual fertility (Macunovich 1998, p.98).

Supportive analyses of the Easterlin hypothesis validate further work in this area. Freeman (1979) studied the effect of changes within the age structure of the workforce on age-earnings profiles in the United States. Because of the "baby boom" that followed World War II and peaked between 1955-1960, there was an especially significant change in the age structure of the U.S. workforce in the late 1960s and early 1970s. This timeframe was a period when the number of young persons increased very rapidly. The key finding was that the age-earnings profile of male workers appears to be significantly influenced by the age composition of the workforce. In prior studies, the age-earnings profile was usually viewed as a stable economic relationship determined by human capital investment decisions, assuming that earnings only rise with age and experience as a result of individual investment behavior. Freeman notes that from the late 1960s through the mid-1970s, when the number of young workers increased rapidly, the earnings of young male workers fell relative to the earnings of older male workers, altering male age-earnings profiles, particularly for college graduates.

Welch (1979) scrutinized the 1968-1976 March Current Population Surveys (CPS) in order to assess the impact of the change in age composition experienced by the United States. due to the entrance of the post-World War II baby boom cohorts into the job market. The main hypothesis was again that the changing age composition of the workforce affected earnings patterns. The key finding was that the pressure of a workforce whose average age is rapidly declining results in the reduction of the wages of new entrants. Welch points out that there is strong evidence that large cohorts do depress earnings, and that these effects increase with level of schooling. Moreover, most of the negative effect on earnings 
comes early in the individual's career, suggesting that negative effects rapidly diminish and reach a smaller permanent level at a relatively young age.

Berger (1985) suggests that the negative effects of cohort size on earnings do not diminish rapidly, contrary to what Welch observes. Cohort size also has a negative effect on early career earnings growth, which is in opposition to Welch's findings. The impact of cohort size on earnings may actually increase throughout the careers of individuals in large cohorts. These trends are explained by Berger, as follows:

(...) using data almost identical to those employed by Welch, the restrictions inherent in his empirical model are rejected in favor of a more general model, which involves separate earnings equations for older and younger worker subsamples. (...) Cohort size effects on earnings levels appear to widen with experience, suggesting a continually increasing cohort size earnings 'penalty' as workers in large cohorts move through their careers. This suggests that there will be no quick recovery of the earnings levels of workers in large entry cohorts as is implied by Welch's study. At the very least, the lower observed rates of earnings growth in large cohorts are consistent with slower speeds of transition between the learning and fully trained stages of the career (Berger 1985, p.572).

These cohort-size studies suggested that shifts in factor supply (the baby boom) led to a decline in wages, so that demand shifts did not explain all the wage variation. By the same token, an increase in the supply of skilled labor should lead to a relative decline in the wage of skilled relative to unskilled labor. In the context of a production function with a constant elasticity of substitution (CES) and downward-sloping demand for relative skill, an increase in the provision of skilled labor will lead to a decline in the skill premium (defined as the wage of skilled workers divided by that of unskilled). In developed countries, in contrast, the skill premium increased while the supply of educated workers has risen steadily. Katz and Murphy (1992) found that the relative supply of skilled labor combined with smoothly rising demand explains U.S. relative wage trends between 1967 and 1987. Autor et al (1998) used a longer time series to test the smooth rising demand 
hypothesis, and found some evidence that accelerating demand rationalized the U.S. wage premium shifts. An alternative justification for the rising wage premium is the role of trade, the U.S. engagement with countries in which skills are relatively scarce. An institutional explanation may also be suggested to the extent that the real minimum wage and the bargaining power of unions declined during this period.

Triest et al (2006) have conducted the most recent analysis of population aging and the structure of wages in the United States. Their research explores the effect of labor market experience, relative cohort size and real wage growth on real wages by level of education using the March Current Population Survey (CPS) from 1964 and 2004. Referring to the Census Bureau, the authors emphasize that the working population in the United States will increase by 13 percent between 2001 and 2025, but the population between 60 and 64 years of age will increase by 90 percent. This process shows that the cohorts of baby boomers are entering retirement ages, increasing the elderly dependency ratio, as well as decreasing the growth rate of the working age population. This demographic dynamic will have some influence on economics: "as a consequence, labor supply may grow at a slower rate than labor demand, putting upward pressure on wages and creating tight labor market conditions. Often overlooked, however, is the fact that the age distribution of the labor force will also be changing." (Triest et al 2006, p.1)

Triest et al's models indicate that: (1) increases in relative cohort size are associated with decreases in wages; (2) although real wages initially increase with labor market experience, there is a significant decrease in the rate of growth as experience increases; (3) there was a general increase in the economic return to educational attainment; (4) changes in the age and experience composition of the labor force will continue to have an important influence on the structure of wages; (5) the initial increase in the experience premium generated by the baby boom's entry into the labor market is now being reversed as the baby 
boom progresses through middle age and approaches retirement. More specifically, the authors stress that baby boomers born in 1950 encompassed a large fraction of the college educated labor force when they entered the labor market. At that time, their wages would have been 18 percent higher if their relative cohort size was the same as that of the 1970 cohort when entering the labor force. Large cohorts depress their own wages relative to those of other cohorts in the labor force at the same time. Triest et al imply that changes in the age and experience composition of the labor force will continue to have an important influence on the structure of wages.

While these studies all refer to the U.S. case, they illustrate the power of the supplydemand framework and the richness of combining age and schooling as basic labor inputs, thus driving wage variations. 


\section{Chapter 3. Brazilian background and data}

\section{DEMOGRAPHIC TRANSITION IN BRAZIL}

Martine et al (1994) observe that since the 1970s Brazilian society has been experiencing a significant reduction in fertility rates. This decline caused a significant reduction of the population growth rate, as well as a change in age structure in the country. They consider this change to be the most significant structural variation to have occurred in Brazil at the end of the 20th century. They estimated that the total fertility rate in the country fell from 6.5 in 1940, to 6.3 in 1950, 5.8 in 1970, and 4.3 in 1980. Projections for the following decades were also done, generating the following figures for the total fertility rate: 2.87 (1990-1995), 2.63 (1995-2000), 2.41 (2000-2005), 2.20 (2005-2010), 2.19 (2010-2015), and 2.19 (2015-2020). Some other estimates were also done by Potter et al (2002), referencing total fertility rates equal to 6.0 in $1960,6.0$ in $1970,4.8$ in 1980 , and 3.2 in 1991.

By observing this downward trend in fertility, Martine et al suggest that a social policy program should be considered for the medium and long term. In other words, they indicate the need for Brazilian society to be prepared for the new context of social demands that will be generated by aging population. This shift in the demographic pattern creates a positive environment to solve social problems inherent in the country. On one hand, the youth population is decreasing its proportional participation in the overall population. On the other hand, the older population is not growing as fast as the working population. Because of this trend, the country can improve its indicators in the attainment and quality of education for the youth, as well as in the social security system and health care of the

older age groups. The implications of these demographic changes on the labor market are not extensively debated. However, they suggest that the female participation in the labor 
market is increasing; the pressure of new cohorts on the market is not unbearably strong, because of the decline of people below 15 years of age; the improvement in years of schooling delays the search for jobs; and the occupation and income patterns are adapting from a rural into a more urban structure.

Moreira (2001) also emphasizes the important role of fertility decline in the transformation of Brazilian age structure. Analyzing the interrelationships between age groups, it is noticed that both the child dependency ratio and the aged dependency ratio determined the decline of the total dependency ratio. The projection shows that the total dependency ratio will reach the minimum values between 2010 and 2020. This period which will last until approximately 2025 was characterized as a "window of opportunity" by Carvalho and Wong (1999). Suggesting the same perspective as the studies developed about East-Asian countries, these authors indicate that the opportunity to improve socioeconomic resources to focus on the young population, and the possibility to plan policies in order to address the challenges of a growing elderly population are some of the beneficial assets that Brazil will face with the new age structure patterns.

Carvalho and Garcia (2003) analyze the process of aging relating to the Brazilian population. They stress that the proportional increase of older age groups is due to the fertility decline, rather than a mortality decline. The age distribution was constant until the 1960s, and was characterized by a young population, in which 52 percent were concentrated below 20 years of age, and less than three percent of the population was over 65 years of age. Following this period, mortality had a significant decline, mainly in the area of infant mortality. Estimations and projections made by the Brazilian Census Bureau indicate the decline of the infant mortality rate per thousand: 162.4 in 1930, 150.0 in 1940, 135.0 in $1950,124.0$ in $1960,115.0$ in $1970,82.8$ in $1980,48.3$ in 1990 (IBGE 1999a), 33.74 in 2000, 27.96 in 2010, and 27.11 in 2020 (IBGE 1999b). The life expectancy at 24 
birth increased over time: 41.2 in 1940, 43.6 in 1950, 53.7 in 1970, 59.9 in 1980 (Martine et al 1994), 66.03 in 1991, 68.55 in 2000, 70.08 in 2010, and 70.37 in 2020 (IBGE 1999b). Estimations and projections of the medium variant models from the United Nations are also included to show the trends of total fertility rate, infant mortality rate, life expectancy at birth, and dependency ratios in Brazil, between 1950 and 2050 (Table 3.1 and Figure 3.1). 
Table 3.1. Total Fertility Rate, Infant Mortality Rate and Life Expectancy at Birth in Brazil, 1950-2050.

\begin{tabular}{c|ccc}
\hline Period & $\begin{array}{c}\text { Total } \\
\text { Fertility Rate }\end{array}$ & $\begin{array}{c}\text { Infant Mortality } \\
\text { Rate (per 1,000 births) }\end{array}$ & $\begin{array}{c}\text { Life Expectancy } \\
\text { at Birth (years) }\end{array}$ \\
\hline $1950-1955$ & 6.15 & 134.7 & 50.9 \\
$1955-1960$ & 6.15 & 121.9 & 53.3 \\
$1960-1965$ & 6.15 & 109.4 & 55.7 \\
$1965-1970$ & 5.38 & 100.1 & 57.6 \\
$1970-1975$ & 4.72 & 90.5 & 59.5 \\
$1975-1980$ & 4.31 & 78.8 & 61.5 \\
$1980-1985$ & 3.8 & 63.3 & 63.1 \\
$1985-1990$ & 3.1 & 52.4 & 64.9 \\
$1990-1995$ & 2.6 & 42.5 & 66.6 \\
$1995-2000$ & 2.45 & 34.1 & 68.8 \\
$2000-2005$ & 2.35 & 27.4 & 70.3 \\
$2005-2010$ & 2.25 & 23.6 & 71.9 \\
$2010-2015$ & 2.15 & 20.3 & 72.9 \\
$2015-2020$ & 2.06 & 17.1 & 74.2 \\
$2020-2025$ & 1.98 & 14.3 & 75.2 \\
$2025-2030$ & 1.92 & 12.1 & 76.2 \\
$2030-2035$ & 1.86 & 10.3 & 77 \\
$2035-2040$ & 1.85 & 9.1 & 77.8 \\
$2040-2045$ & 1.85 & 8.1 & 78.5 \\
$2045-2050$ & 1.85 & 7.5 & 79.2 \\
\hline
\end{tabular}

Source: United Nations — http://esa.un.org/unpp (in August 16, 2006 — medium variant). 
Figure 3.1. Dependency Ratios in Brazil, 1950-2050.

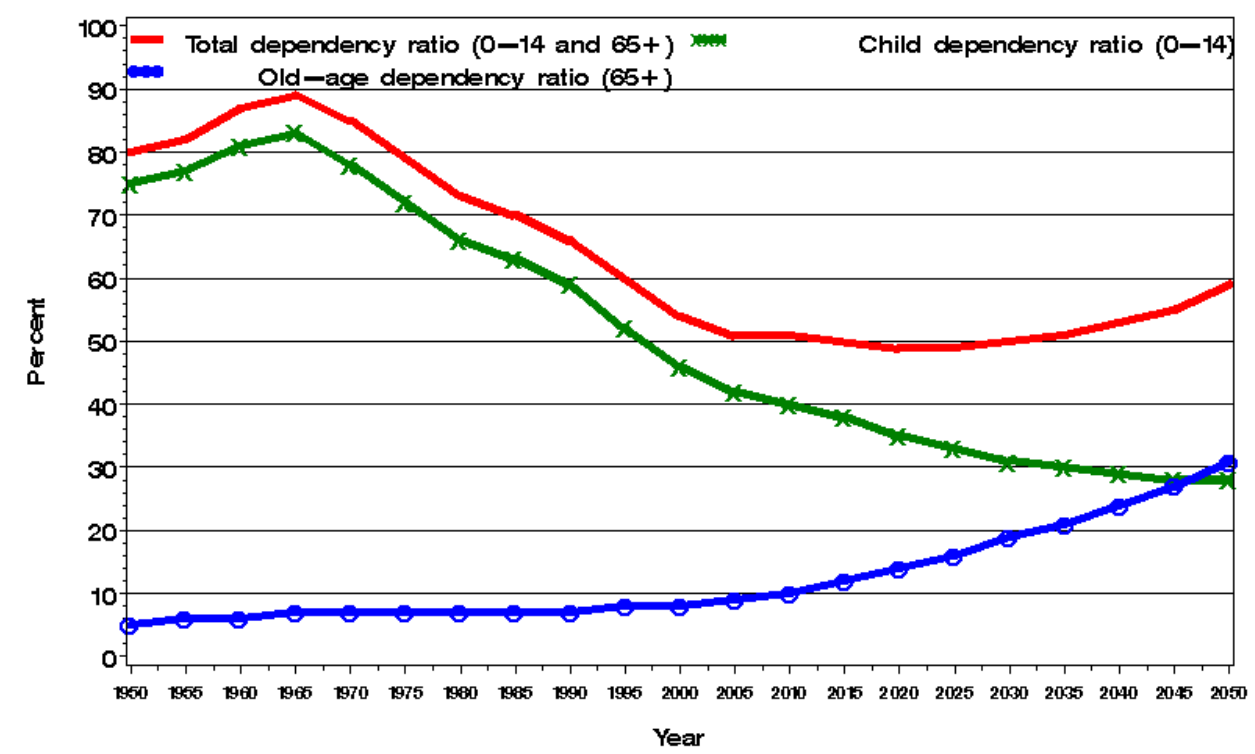

Source: United Nations — http://esa.un.org/unpp (in August 16, 2006 — medium variant).

By analyzing the United Nations data, Alves (2004) determines that the demographic transition can benefit the economic development of Brazil. However, this demographic bonus will result in economic growth only if the available labor force is absorbed by the market through the implementation of appropriate policies. Those policies should take into account the better health indicators, education, and habitation in order to promote the economic development. After 2030, the demographic conditions will not be as favorable for this advancement, which can be observed by the increased projections in the dependency ratios.

Wong and Carvalho (2005) also investigate the challenges Brazilian society will face as a result of the transition in age structure. The authors suggest that the window of opportunity experienced in Brazil will not result in the automatic solution of social problems. The new population dynamics should be taken into account in order to implement social policies. In their analysis, many of the demographic benefits have already 
been wasted because appropriate policies were not implemented. Labor force skills should be improved, in order to promote higher productivity. The working population is the group that will be forced to support the rapidly growing older population in the future. The elderly will drain resources through the use of the social security system and public health care. Wong and Carvalho conclude that the window of opportunity has a short duration, and it will go unutilized if reforms in policies for older people are not applied, and if funding programs for the younger population are not executed.

Rios-Neto (2005) emphasizes that the Brazilian demographic dynamic, related to its changing age structure, offers an opportunity for economic development. Moreover, the increase in maternal education might increase the demand for schooling, as well as improve the quality of the school system. The education attainment in the country increased, because the proportional reduction of the population under 15 years of age is decreasing the pressure on the school system. Finally, Rios-Neto concludes that numerous other factors, separate from the study of the demographic dividend, need to be addressed. Researchers should also investigate the intergenerational transfers within Brazilian society.

\section{MiCRODATA}

The shocks that generated subsequent changes in relative labor supply by cohort began some decades ago in Brazil, with data suggesting that fertility decline initiated in the 1940s in Porto Alegre, São Paulo, and Rio de Janeiro. In the early 1960s, the decline in fertility in the metropolitan areas of Rio de Janeiro, São Paulo, and Porto Alegre led to total fertility rates below five. From these locations the decline spread to the interior of these Southeastern states, and to the capital cities of states in the Central-West, North and Northeast, finally reaching the interior and rural areas of those regions in the 1980s. At the 
municipal level in 2000 there were a substantial number of entities with total fertility rates above four, while there were also many where fertility had fallen below replacement. The variation in the timing and speed of the fertility transition led to substantial differences in the age distribution across states and municipalities, as well as across different points in time (Potter et al 2002).

The longest series of data on age, education and earnings come from the Brazilian Censuses conducted in 1960, 1970, 1980, 1991, and 2000. Microdata from these Censuses are available from long-form questionnaires administered to 25-percent samples in 1960, 1970, and 1980. In 1991 and 2000 the sample sizes depended on the size of the municipality, with 10-percent samples from municipalities with more than 15,000 inhabitants, and 20-percent samples from all other municipalities. In all cases there are records for every individual in the sampled households, containing information on age, gender, marital status, educational attainment, enrollment in school, and, if employed, occupation and earnings. There are also questions on migration, including state of birth, previous residence, and residence five years before the Census.

The lowest level of geographic identifier on these records common to all Censuses is the município, since information on distritos, the sub-divisions of municípios, is not available in the Census microdata. In a previous work, Potter et al (2002) established minimum comparable areas that account for the changing definitions and divisions of municípios across the Census years, which is necessary since their number increased from approximately 2,300 in 1960 to 5,280 in 2000 . The authors were able to aggregate minimum comparable areas into 502 micro-regions across the five Censuses. It is important to note that these micro-regions differ from those defined by the Brazilian Institute of Geography and Statistics (IBGE) and those available in the Census microdata, but closely approximate those defined for the 1991 Census. It is thus possible to calculate various 
statistics summarizing the age distribution, labor-market outcomes and education indicators for each of these 502 consistently defined areas in each of the five Censuses. In the end, because the 1960 Census categorized earnings by bracket, this Census is excluded and the analyses are based on the Censuses beginning in 1970.

Since there is a very pronounced trend in the age distribution that has substantial variation across regions, states and municipalities, this study seeks to take advantage of this change at the micro-region level. Using these very small geographical units poses the question of internal migration, which has not been incorporated in most preceding analyses conducted at the national level. The migration component could be an important factor in this context, since the main population streams have been moving from areas with higher fertility to those with lower fertility. While such migration tends to lessen the differential in fertility between sending and receiving areas, the greater likelihood that migrants will be of working age actually increases the variation in dependency rates. Borjas et al (1997) develop a discussion of the role of internal migration on modifying the impacts of exogenous changes in relative supply on relative wage rates. This potential problem will be discussed in more detail later.

\section{Creating aggregate-Level data}

Census microdata were aggregated in such a way that for each micro-region there are 48 observations, since age was categorized into four groups, education into three groups, and four different Census years were used (1970, 1980, 1991, and 2000), as it will be explained below. A new age-education variable with twelve categories was developed. For each micro-region, age-education, and year cells, the mean income was calculated, 
accounting for currency changes and inflation. The distribution of males ages 15-64 in each age-education group was also calculated by micro-region in each Census year.

The decision to generate age and education groups in the analysis of earnings was based on previous labor market studies. Hamermesh (1993) indicates that it is difficult to know whether a particular aggregation of labor is appropriate, therefore studies generally aggregate workers that present similar characteristics in the labor market. The classification of workers by experience and/or age has been used in previous studies on human capital, emphasizing that this is a validated way to classify workers by skill in studies on labor demand. Suggesting that researchers have to aggregate workers based on intuition, Hamermesh states that:

(...) this aggregation almost always involves simply summing the number of workers, so that the even stronger assumption that the workers are equally productive is also implicit. It also implies that the individuals who are aggregated are separable from the other inputs. (...) Studies that create their own aggregates by examining substitution among very narrowly defined groups of workers, or even among individuals, are more believable than those that take published aggregates and analyze the demand for them (Hamermesh 1993, pp.65 and 67).

Welch (1979) found that workers in adjacent experience cells are more likely to influence each other's labor market opportunities (within educational attainment) than workers in different experience groups (between educational attainment groups). Taking into account Welch's findings, Borjas (2003) and Triest et al (2006) classified information on education attainment in different groups for the estimation of labor outcomes models. Borjas (2003) analyses the impact of immigrant share on labor market outcomes in the United States by different education groups. He utilized separate models for four education groups: high-school dropouts, high-school graduates, persons who have some college (between thirteen and fifteen years of schooling), and college graduates or more. Using the March Current Population Survey (CPS) from 1964 to 2004, Triest et al (2006) calculate 
the impact of labor market experience and relative cohort size on the level of real wages using five different levels of education: (1) less than high school (high school dropouts), (2) high school graduates, (3) individuals with some college, (4) college graduates, (5) individuals with post-college education (graduate education).

Borjas (2003) and Triest et al (2006) created variables for labor market experience based on information of the age and educational attainment of workers. Borjas:

(...) assume[s] that the age of entry into the labor market is 17 for the typical high school dropout, 19 for the typical high school graduate, 21 for the typical person with some college, and 23 for the typical college graduate. Let $A T$ be the assumed entry age for workers in a particular schooling group. The measure of work experience is then given by $(A g e-A T)$. I restrict the analysis to persons who have between 1 and 40 years of experience (Borjas 2003, p.1341).

Triest et al (2006) also constructed defined groups of work experience based on age and educational attainment: (Age - 17) for high school dropouts; (Age - 18) for high school graduates; (Age - 20) for people with some college; (Age - 22) for college graduates; and $($ Age - 24) for people with graduate education.

In this analysis, the labor force is categorized into four age groups: Youths (15-24), young adults (25-34), experienced adults (35-49) and older adults (50-64). The widths of the age categories are unequal in order to make the fractions in each category somewhat more equal. In light of the immense evidence on the role of education in defining subaggregates of labor (Hamermesh 1993, chapter 3; Borjas 2003), workers are crossclassified by their educational attainment based on Riani (2005).

Riani notes that by 2000 the majority of Brazilians between ages 7 and 14 were in school, and large fractions were completing elementary school. Moreover, she observes that there was a decrease in regional, racial and rural-urban differentials in elementary school attainment. On the other hand, although more people are attending secondary school, the proportion of people with between nine and 12 years of schooling is still small, 
and regional differences are still significant. Riani emphasizes that elementary education is spreading to the whole population. However, since completion of high school is still low, the differentials tend to increase because people with better socioeconomic status are the first ones to obtain more education. Taking into account the specifics of the Brazilian population, workers are classified by educational attainment into three main groups: Zero to four years, five to eight years, and at least nine years of schooling. The first group includes people who completed no further than the first phase of elementary school. The second group contains people who completed some or all of the second phase of elementary education. The third group is comprised of people with at least some secondary education.

Because of the differences in educational attainment by cohorts, using separate vectors of indicators for age and education would overlook the rapid change in educational attainment across cohorts, resulting in multicollinearity in the estimated factor-price elasticities. To obviate this difficulty, a full set of interactions of the four age indicators and the three education categories are generated. For each of the twelve cells, for each micro-region and each year, mean earnings and the proportion of males in each ageeducation group are calculated.

Jannuzzi (2003) summarizes all income variables available in the 1960-2000 Brazilian Censuses. For workers with fixed incomes, this information refers to gross earnings received in the month previous to the Census reference date (or the last worked month). For those with varying incomes (self-employed, employers, workers by commission, and others), earnings refer to the mean of monthly gains received in the previous 12 months before the Census date (or to the mean of monthly gains for the time worked, for those who worked less than 12 months), minus usual work costs. From 1960 to 1980 , the reference month in the Censuses was the one at the time of the interview. In 
1991, the Census reference month was August of that year. For 2000, July was the month of reference.

In the 1960 and 1970 Censuses, the information on earnings refers to the total of monthly income from all sources, for people with at least ten years of age. Earnings include only regular income, excluding gains from real estate, retirement pension, and insurance, for instance. However, Jannuzzi emphasizes that retirement pensions had a small value at that time, and the proportion of the population receiving retirement pensions was insignificant. Moreover, the inequality was extemely accentuated in the 1960s and 1970s, thus the number of people receiving income from real estate, interest rates or other sources was irrelevant. Therefore, the information on total monthly income can be taken as a proxy to the main occupation earnings. In reality, this information might even be sub-estimated in rural areas, for instance, due to the exclusion of products and groceries not included in the total earnings.

Jannuzzi indicates that information about earnings of the main occupation started to be collected in the 1980 Census. The various forms of earnings (main occupation, other occupations, retirement pension, real estate rental fee, donations, government benefits, and other sources) vary between the 1980 and 2000 Censuses. In general, these income variables allow a precise discrimination of earnings in the main occupation, for people with ten years of age or more, from other sources of earnings.

For the 1970 Census information on total earnings was used in this study. For the 1980-2000 Censuses, information on earnings of the main occupation was utilized. The 1960 Census was not included in this analysis because information for earnings is categorized in the microdata, and not continuous as in the other Censuses.

A concern that arises with the use of earnings variables is the amount of missing values in the database. Table 3.2 shows the distribution of missing values of the selected 
earnings variable in each year by age-education group, as well as the total number of males by age-education group from 1970 to 2000 . First, one can see that the percentage of missing values for the least educated group in all age groups increased through time. This might be an indication that the increase in education enrolment generates a reduction of the proportional amount of people joining the labor market while they are attending school. Moreover, data from the 1970 Census has a smaller percent of missing values compared to the other Censuses. The use of total earnings in 1970, which is the only variable available, might reduce the amount of missing variables. On the other hand, the use of earnings of the main occupation in the 1980-2000 Censuses is demonstrating that this variable has a greater proportion of missing values than the one in 1970. However, differences in the proportion of missing values across years, as well as across age-education groups, are controlled in the estimated regression models by the inclusion of indicator variables for each one of these groups and years. Furthermore, possible variation in the proportion of missing earnings across micro-regions is also controlled by the use of fixed-effects models, which estimate one coefficient for each one of these areas, as it will be explained below. 
Table 3.2. Distribution of Missing Values of Earnings by Age-Education Group and Year, and Total Number of Observations ${ }^{+}, 1970-2000$.

\begin{tabular}{|c|c|c|c|c|c|}
\hline Age-Education Group & 1970 & 1980 & 1991 & 2000 & Total \\
\hline $\begin{array}{c}15-24 \text { years } \\
0-4 \text { years of schooling }\end{array}$ & $\begin{array}{c}38.70 \\
(1,897,157)\end{array}$ & $\begin{array}{c}31.49 \\
(1,614,811)\end{array}$ & $\begin{array}{c}39.45 \\
(787,334)\end{array}$ & $\begin{array}{c}52.96 \\
(630,244)\end{array}$ & $\begin{array}{c}38.28 \\
(4,929,546)\end{array}$ \\
\hline $\begin{array}{c}15-24 \text { years } \\
5-8 \text { years of schooling }\end{array}$ & $\begin{array}{c}55.70 \\
(356,082)\end{array}$ & $\begin{array}{c}38.22 \\
(831,555)\end{array}$ & $\begin{array}{c}38.24 \\
(577,387)\end{array}$ & $\begin{array}{c}53.45 \\
(780,157)\end{array}$ & $\begin{array}{c}45.34 \\
(2,545,181)\end{array}$ \\
\hline $\begin{array}{c}15-24 \text { years } \\
9+\text { years of schooling }\end{array}$ & $\begin{array}{c}54.14 \\
(178,501)\end{array}$ & $\begin{array}{c}38.32 \\
(469,429)\end{array}$ & $\begin{array}{c}36.13 \\
(274,064)\end{array}$ & $\begin{array}{c}43.85 \\
(604,423) \\
\end{array}$ & $\begin{array}{c}41.97 \\
(1,526,417)\end{array}$ \\
\hline $\begin{array}{c}25-34 \text { years } \\
0-4 \text { years of schooling }\end{array}$ & $\begin{array}{c}7.65 \\
(1,351,534)\end{array}$ & $\begin{array}{c}8.77 \\
(1,370,213)\end{array}$ & $\begin{array}{c}11.14 \\
(645,030)\end{array}$ & $\begin{array}{c}25.88 \\
(596,157)\end{array}$ & $\begin{array}{c}11.35 \\
(3,962,934)\end{array}$ \\
\hline $\begin{array}{c}25-34 \text { years } \\
5-8 \text { years of schooling }\end{array}$ & $\begin{array}{c}6.22 \\
(132,772)\end{array}$ & $\begin{array}{c}5.16 \\
(319,702)\end{array}$ & $\begin{array}{c}8.95 \\
(324,439)\end{array}$ & $\begin{array}{c}17.25 \\
(461,042)\end{array}$ & $\begin{array}{c}10.77 \\
(1,237,955)\end{array}$ \\
\hline $\begin{array}{c}25-34 \text { years } \\
9+\text { years of schooling }\end{array}$ & $\begin{array}{c}8.66 \\
(133,061)\end{array}$ & $\begin{array}{c}6.18 \\
(390,430)\end{array}$ & $\begin{array}{c}7.63 \\
(336,992)\end{array}$ & $\begin{array}{c}12.27 \\
(463,498)\end{array}$ & $\begin{array}{c}8.93 \\
(1,323,981)\end{array}$ \\
\hline $\begin{array}{c}35-49 \text { years } \\
0-4 \text { years of schooling }\end{array}$ & $\begin{array}{c}4.62 \\
(1,544,672)\end{array}$ & $\begin{array}{c}10.13 \\
(1,533,000)\end{array}$ & $\begin{array}{c}9.22 \\
(898,240)\end{array}$ & $\begin{array}{c}23.97 \\
(901,348)\end{array}$ & $\begin{array}{c}10.77 \\
(4,877,260)\end{array}$ \\
\hline $\begin{array}{c}35-49 \text { years } \\
5-8 \text { years of schooling }\end{array}$ & $\begin{array}{c}2.85 \\
(108,556)\end{array}$ & $\begin{array}{c}6.60 \\
(194,614)\end{array}$ & $\begin{array}{c}8.06 \\
(170,897)\end{array}$ & $\begin{array}{c}16.96 \\
(404,879)\end{array}$ & $\begin{array}{c}11.20 \\
(878,946)\end{array}$ \\
\hline $\begin{array}{c}35-49 \text { years } \\
9+\text { years of schooling }\end{array}$ & $\begin{array}{c}3.40 \\
(106,324) \\
\end{array}$ & $\begin{array}{c}3.88 \\
(231,802) \\
\end{array}$ & $\begin{array}{c}5.58 \\
(250,225) \\
\end{array}$ & $\begin{array}{c}10.19 \\
(480,039)\end{array}$ & $\begin{array}{c}7.06 \\
(1,068,390) \\
\end{array}$ \\
\hline $\begin{array}{c}50-64 \text { years } \\
0-4 \text { years of schooling }\end{array}$ & $\begin{array}{c}7.89 \\
(879,083)\end{array}$ & $\begin{array}{c}25.09 \\
(965,822)\end{array}$ & $\begin{array}{c}24.54 \\
(598,336)\end{array}$ & $\begin{array}{c}39.12 \\
(690,787)\end{array}$ & $\begin{array}{c}23.25 \\
(3,134,028)\end{array}$ \\
\hline $\begin{array}{c}50-64 \text { years } \\
5-8 \text { years of schooling }\end{array}$ & $\begin{array}{c}4.10 \\
(43,587)\end{array}$ & $\begin{array}{c}29.26 \\
(76,734)\end{array}$ & $\begin{array}{c}33.88 \\
(53,033)\end{array}$ & $\begin{array}{c}37.03 \\
(116,799)\end{array}$ & $\begin{array}{c}29.45 \\
(290,153)\end{array}$ \\
\hline $\begin{array}{c}50-64 \text { years } \\
9+\text { years of schooling }\end{array}$ & $\begin{array}{c}5.05 \\
(41,680)\end{array}$ & $\begin{array}{c}20.34 \\
(85,628)\end{array}$ & $\begin{array}{c}31.09 \\
(76,381)\end{array}$ & $\begin{array}{c}32.06 \\
(157,873)\end{array}$ & $\begin{array}{c}25.97 \\
(361,562)\end{array}$ \\
\hline Total & $\begin{array}{c}19.25 \\
(6,773,009)\end{array}$ & $\begin{array}{c}20.12 \\
(8,083,740)\end{array}$ & $\begin{array}{c}21.16 \\
(4,992,358)\end{array}$ & $\begin{array}{c}31.88 \\
(6,287,246)\end{array}$ & $\begin{array}{c}22.92 \\
(26,136,353)\end{array}$ \\
\hline
\end{tabular}

${ }^{+}$Information between parentheses is the total number of observations un-weighted in the age-education group by year.

The other numbers refer to the percent of missing values in the total amount of observations of each table cell.

Source: 1970-2000 Brazilian Censuses.

All nominal amounts are calculated in the currency as of January 2002. To account for currency changes, wages in 1970 and 1980 were divided by 2,750,000,000,000; and in 1991, they were divided by 2,750,000, as suggested by Corseuil and Foguel (2002). This correction was followed by the use of deflators suggested by the same authors (wages were 
then divided by 0.00000000000026439 in $1970 ; 0.0000000000057782$ in 1980; 0.000067602304350 in 1991; and 0.902716061809642 in 2000). In 1960, wages would have been divided by 2,750,000,000,000,000 to account for currency changes; and by 0.0000000000000068879 for inflation correction. Both adjustments for currency changes and for deflation are done for convenience only. Taking logarithms of wages, using nominal or real wages, generates the same estimates of the crucial parameters.

Table 3.3 presents mean real monthly earnings of males by age-education group and year. The analysis of this table has to take into account that levels and patterns of mean earnings might be influenced by great variations among individuals, within each ageeducation group. Keeping this in mind, these mean earnings are still a useful instrument to have an initial idea of differences across groups over time. As expected, earnings are greater for better educated and older males. The increase in the means of earnings from 1970 to 1980 is justified by the great economic growth experienced in Brazil during the 1970s. Because of the economic recession in the 1980s, earnings dropped in 1991. From 1991 to 2000, mean earnings increased for the least educated males in all age groups, and for the highest educated males in the oldest group. For the other groups, earnings dropped slightly from 1991 to 2000, resulting in smaller disparities across education groups within each age group in 2000 .

Because of the great variation in income distribution in Brazil, the dependent variable in all models is the logarithm of mean real earnings in a group defined by microregion, age-education cell and year. In order to minimize potential problems of heteroskedasticity, cells containing fewer than 25 males receiving earnings are excluded from the regression analyses. Time refers to four different Censuses used in the study: 1970, 1980, 1991, and 2000. 
Table 3.3. Mean Real Monthly Earnings of Male Population by Year and Age-Education Group, 1970-2000+.

\begin{tabular}{|c|c|c|c|c|}
\hline $\begin{array}{c}\text { Age-education } \\
\text { Group }\end{array}$ & 1970 & 1980 & 1991 & 2000 \\
\hline $\begin{array}{c}15-24 \text { years } \\
0-4 \text { years of schooling }\end{array}$ & 158.54 & 276.29 & 196.05 & 213.23 \\
\hline $\begin{array}{c}15-24 \text { years } \\
5-8 \text { years of schooling }\end{array}$ & 285.87 & 359.01 & 261.94 & 250.15 \\
\hline $\begin{array}{c}15-24 \text { years } \\
9+\text { years of schooling }\end{array}$ & 530.31 & 641.81 & 428.00 & 361.56 \\
\hline $\begin{array}{c}25-34 \text { years } \\
0-4 \text { years of schooling }\end{array}$ & 227.16 & 439.51 & 289.52 & 303.49 \\
\hline $\begin{array}{c}25-34 \text { years } \\
5-8 \text { years of schooling }\end{array}$ & 585.02 & 818.99 & 472.21 & 459.94 \\
\hline $\begin{array}{c}25-34 \text { years } \\
9+\text { years of schooling }\end{array}$ & $1,183.87$ & $1,562.22$ & 894.31 & 834.13 \\
\hline $\begin{array}{c}35-49 \text { years } \\
0-4 \text { years of schooling }\end{array}$ & 273.56 & 551.83 & 381.59 & 394.58 \\
\hline $\begin{array}{c}35-49 \text { years } \\
5-8 \text { years of schooling }\end{array}$ & 845.03 & $1,316.54$ & 755.74 & 668.49 \\
\hline $\begin{array}{c}35-49 \text { years } \\
9+\text { years of schooling }\end{array}$ & $1,661.43$ & $2,348.69$ & $1,557.74$ & $1,482.51$ \\
\hline $\begin{array}{c}50-64 \text { years } \\
0-4 \text { years of schooling }\end{array}$ & 275.46 & 553.77 & 380.52 & 436.81 \\
\hline $\begin{array}{c}50-64 \text { years } \\
5-8 \text { years of schooling }\end{array}$ & 978.13 & $1,587.19$ & 918.25 & 913.82 \\
\hline $\begin{array}{c}50-64 \text { years } \\
9+\text { years of schooling }\end{array}$ & $1,724.94$ & $2,823.26$ & $1,826.73$ & $2,080.80$ \\
\hline Total & 711.47 & $1,093.98$ & 694.56 & 699.24 \\
\hline
\end{tabular}

This analysis was done using models in which there was a fixed-effect for each micro-region. These areas were first homogenized by Potter et al (2002) in 518 areas, in order to have comparable areas across the 1960, 1970, 1980, and 1991 Censuses. To 
incorporate the 2000 Census, micro-regions were redefined by the same authors into 502 comparable areas across Brazil. In Potter et al's study, the:

(...) model has 518 intercept terms (one per micro-region), and its slope coefficients $\beta$ represent the average fertility effects of unit changes in indicators, holding location constant. In essence, with the fixed-effects model, any persistent variability in fertility between micro-regions are net out, so that estimated coefficients reflect relationships within micro-regions over time. The fixed-effects model exploits the fact that identical locations are observed more than once and produces estimates that reflect observed, rather than 'synthetic,' changes in fertility and development indicators (Potter et al 2002, p.748).

In the case of the present research, fixed-effects models will determine how changes in the independent variables over time will alter local labor outcomes.

Throughout the estimation, I only use data on the male population. This is restrictive, but it concentrates on a group whose labor-force participation is relatively unresponsive to wages, and thus buttresses the treating quantities as exogenous. With this restriction (and, of course, with the exclusion of information on capital stocks by area), there is the implicit assumption of separability of the inputs of male workers of various types from other inputs. More specifically, Hamermesh explains that:

(...) the availability of data also dictates that many studies exclude measures of the stock of capital. For the same reason other studies concentrate on the demand for one or several types of workers and exclude much of the total input of labor from the estimation. (...) There is nothing inherently wrong with ignoring capital or some part of the work force, assuming problems of separability are resolved. Estimates of factor-demand or factor-price elasticities are readily interpretable, but they must be interpreted carefully. Otherwise, one will, for example, underestimate own-price demand elasticities and infer that two groups of labor are greater $p$-substitutes than they in fact are (Hamermesh 1993, pp.67-68).

In the case of own-quantity elasticities of factor price, the misleading interpretation would suppose that two groups of labor are greater $q$-complements than real trends. Greater $p$-substitutability and $q$-complementarity estimates would lead to uninteresting results, such as it will be explained in following sections. 
Although the calculation of all variables used in the models took into account sample weights available in the microdata, weights were not used in the fixed-effects estimates. In other words, because fixed-effects models reflect relationships within microregions over time, between-micro-region sample variations are excluded from the analysis.

In terms of this econometric matter, the appropriate weight to use in regression estimates should have been the square-root of the number of men with earnings in each micro-region, age, education, and year cell. Since the use of weights in a regression model is applied to all coefficients, including the constant, this would imply that the constant would vary for each micro-region over time. However, the use of weights is not allowed in fixed effects models, because the constant does not vary over time within the variable taken for fixed-effect estimates (in this case the micro-region).

A substantial problem might emerge in the regression models if the impacts of proportions of men by age-education groups on earnings change according to the population size of the micro-region. If the impacts do not vary for different sizes of population in the areas, the new estimates will be similar to the original models. In this case, the functions are homothetic, and interactions of proportions with micro-region-size indicators do not need to be included in the models. Shephard explains that "a production function of the independent factor variables $\mathrm{x}_{1}, \mathrm{x}_{2}, \ldots, \mathrm{x}_{\mathrm{n}}$ will be called Homothetic, if it can be written $\Phi\left(\sigma\left(\mathrm{x}_{1}, \mathrm{x}_{2}, \ldots, \mathrm{x}_{\mathrm{n}}\right)\right)$, where $\sigma$ is a homogeneous function of degree one and $\Phi$ is a continuous positive monotone increasing function of $\sigma . "$ (Shephard 1953, p.41) Thus, a function is homothetic in $\sigma$ if it can be decomposed into an inner function that is monotonically increasing in $\sigma$ and an outer function that is homogeneous of degree one in its argument.

As a strategy to take into account the influence of different population sizes of areas in the prediction of earnings, alternative models were also estimated using indicators for 
size of micro-regions. Micro-regions were divided into four groups, defined by the percentile distribution of their male population across Census years. The same microregion might have changed its classification over time due to changes in population. In order to take into account population increases over time, as well as different sample sizes across Censuses, this classification utilized the quartile distribution of males receiving earnings in the micro-regions for each one of the years: in 1970 (from 0 and less than 3,535; from 3,535 and less than 6,337; from 6,337 and less than 11,072; from 11,072 to 441,618); in 1980 (from 0 and less than 3,224; from 3,224 and less than 6,420; from 6,420 and less than 11,390; from 11,390 to 625,985); in 1991 (from 0 and less than 2,348; from 2,348 and less than 4,161; from 4,161 and less than 7,433; from 7,433 to 283,717); and in 2000 (from 0 and less than 2,326; from 2,326 and less than 4,337; from 4,337 and less than 8,050; from 8,050 to 291,405). Population sizes of micro-regions are smaller in the 1991 and 2000 Censuses, compared to the other ones, because of the different sample sizes ( 25 percent in 1970-1980; and 10 percent or 20 percent in 1991-2000). 


\section{Chapter 4. Formulation of the research design}

\section{REVIEW OF SOME ECONOMIC TERMS AND TRENDS}

\section{Elasticity}

In order to better understand the models estimated in this study, some basic economic terms will be explained within this section. One central term used to interpret models is elasticity, which is a tool that is used to describe the relationship between two variables. Elasticity is defined as the ratio of the percentage change in a dependent variable to a percentage change in an independent variable. For example, an elasticity of -2 means that an increase by one percent in the independent variable provokes a fall of two percent in the dependent variable. Elasticities can be estimated for price, income, prices of related products, and advertising expenditures. Elasticity is then a measure of responsiveness of one variable to another used in economics, and can be calculated for any two related variables

Own-price elasticity of factor demand curve measures how responsive the quantity demanded of good $X$ is to the price of good $X$. In other words, own-price elasticity is the ratio of the percentage change in quantity demanded to the percentage change in price. The own-price elasticity is negative (demand curves slope down) and can take on any value from 0 to $-\infty$. The demand curve is perfectly inelastic when the own-price elasticity is zero. Demand is price inelastic if a one-percent increase in price leads to less than a one percent drop in quantity demanded (between zero and -1). The demand curve is unit elastic when the own-price elasticity equals -1 . Demand is price elastic if a one-percent increase in price leads to more than one percent drop in quantity demanded (between -1 and $-\infty$ ). Finally, the demand curve is perfectly (or infinitely) elastic if the own-price elasticity is $-\infty$ (Perloff 2006, chapter 3). 
There are four basic elasticities used in principles of economics: (1) own-price elasticity of factor demand (also called own-price elasticity of labor demand or own-wage demand elasticity) is a measure of the percentage change in the quantity demanded caused by a percentage change in price. Because the demand function is an inverse relationship between price and quantity the coefficient of price elasticity is always negative; (2) crossprice elasticity of demand is a measure of how a change in the price of good $Y$ will change the quantity demanded of good $X$; (3) income elasticity of demand is the percentage by which the quantity demanded will change if the buyer's income rises by one percent; (4) elasticity of supply is a measure of the responsiveness of sellers to changes in the price of a good.

\section{Inverse demand function}

The equations estimated in this study (explained in detail in following sections) are essentially inverse demand functions, which are derivable from the production function. The first set of equations that will be estimated have only own-quantities, concerning the fraction of people in area $i$ at time $t$ in the particular age-education cell $c$. In other equations, cross-quantity effects are included, constituting in a vector of ten additional variables showing the fraction of workers in other age-education cells, with one cell left out as a reference (if own-effect is included). Thus, in this second equation there will be 11 variables in total. This equation then allows the wage of workers in group $c$ to depend not only on the fraction of workers in group $c$, but also on the distribution of workers across all the other groups. Thus a test of whether the distribution outside one's own group affects

one's wage is a test of the significance of the additional cross-quantity vector. There are restrictions on the sum of the coefficients across equations on each quantity, as well as 
restrictions on the sum within each equation. For example, if one increases the quantity of a particular type of labor by one percent, the effects are constrained by the sum of the shares (elasticity of complementary). In the case of the equation including cross-effects, if one is positive, the other must be negative. These equations can be estimated for each ageeducation group. However, if one includes the other age-education-groups' distributions, in a pooled form, this becomes a system of inverse demand equations.

In order to understand inverse demand functions, some previous studies can be used to elucidate it. The main point is that ordinary demand functions $q_{i}=q_{i}\left(p_{l, \ldots,}, p_{n}, Y\right)$ can be inverted to originate inverse demand functions $p_{i}=p_{i}\left(q_{l}, \ldots, q_{n}, Y\right)($ McKenzie 1977).

Some explanations are also made by Pearce (1964) who uses the following notations. The commodity vector $x$ is a set of quantities $\left(x_{1}, x_{2}, \ldots, x_{n}\right)$ of $n$ goods constituting a bundle to be consumed in a given time period. The price of the $i$ th individual good is symbolized by $p_{i}$. Moreover, because $y$ is a more familiar notation, when income $(y)$ and consumption $(C)$ are not distinguished, the symbol $y$ means $C$ (in this case, $C$ is the total estimated money spent in the time period, or $C_{n}$, also referred as the annual income). Current consumption of any commodity is dependent on all prices and total spending, rather than on current income. Pearce explains that:

(...) under market conditions the individual can choose a unique commodity bundle. This gives demand functions, i.e. a vector value function relating every commodity bundle to prices and spending, written: $x=f(p, y)$. By definition of $y$, this function is also subject to the budget condition $(p, x)=y(\ldots)$ the consumer, when faced with a set of prices, can and does select, with some degree of certainty, a particular commodity bundle (...) At this point it is usual to assume that the function $[x=f(p, y)]$ possesses an inverse. In other words, given any commodity bundle $x^{0}$ and some $y^{0}$, there is a unique set of prices $p^{0}$ which will just induce the consumer to buy $x^{0}$. (...) The attempt was made, therefore, to work backwards and to infer the existence of a quasi-utility function from the fact that individuals choose in the market. (...) The inverse of $[x=f(p, y)]$ will give us $p_{i}$ as a function of all $x$ 's and $y$, and there are good empirical reasons for suspecting this function to be homogeneous of order one in $y . p_{i} / y$ is a function of $x$ 's alone. Thus 
if we write the differential equation $\Sigma p_{i} d x_{i}=0$ we can, by multiplication by an appropriate factor, eliminate $y$ (Pearce 1964, pp.66-67).

Cahuc and Zylberberg (2004) also deal with the discussion about demand functions. They explain that the demand for a particular good depends on, among other things, the price at which a firm sells its products, which constitutes the demand function. However, in order to generate models that are easier to explain, economists estimate the inverse demand function, in which the price depends on the demand for a particular good.

\section{Own- and cross-price elasticities of labor demand \& own- and cross-quantity elasticities of factor price}

In some cases, labor demand does not affect wages — for example when all employment is unionized, or where the supply of labor to a sub-sector is perfectly elastic (the percentage change in quantity demanded is totally explained by the percentage change in price, i.e. factor prices are exogenous). In circumstances such as these, wage elasticities of labor demand allow the estimation of effects of exogenous changes of wage rates on the amount of labor employers demand to use. Then labor-demand-relations estimates provide own-price elasticities of labor demand (also known as own-wage factor-demand elasticities), which estimate the impact of changes in the price of one type of labor on its employment; as well as cross-price effects that estimate this impact on the employment of other types of labor (Hamermesh 1986).

In other cases, wages do not affect labor demand, i.e. the employment of workers of a particular type is constant, and determined by the completely inelastic supply of those workers to the market (the percentage change in the wage rate of workers is completely determined by the percentage change of their labor demanded, i.e. factor quantities are exogenous). In this way, quantity elasticities of factor price indicate the impact of exogenous changes of the demand for labor on wage rates. Then the shape of the labor- 
demand function provides own-quantity elasticities of factor price (also known as ownfactor-price elasticities) which estimate the impact of exogenous changes in supply (due to changes in the labor force demographic structure, or to changes in the preferences of workers for entering different occupations, for example) on the wage rate of these workers in the group whose supply has changed; as well as cross-quantity effects that estimate this impact on the wage of other groups (Hamermesh 1986).

The importance of analyzing the relationship between exogenous changes of wages and the determination of employment, as well as exogenous changes of inelastically supplied labor and the structure of relative wages, is described by Hamermesh:

The derivation of factor-demand relationships with more than two inputs is of general interest to economists and should be of particular interest to labor economists when labor is one of those inputs. In that case we can tell, for example, how employment or wages are affected when the price or quantity of any one of several other inputs changes. It is useful to labor economists when we disaggregate labor along some interesting dimension, for example, age, race, sex, education, immigrant status, skill, occupation. In that case the theory of production with several inputs allows us to infer how changes in the wage rate of one group of workers affect the demand for labor in other groups (following the first polar approach to studying demand, that factor prices are exogenous); or how changes in the supply of one group affect the returns to other types of workers (following the second approach, with factor quantities exogenous) (Hamermesh 1993, pp.33-34).

The own- and cross-partial elasticities of factor demand are symbolized by $\eta_{i j}=\delta \ln X_{i} / \delta \ln w_{j}$, with respect to a change in wage rate $w_{j}$. When $\eta_{i j}<0$ for $j \neq i$, "an increase in the wage rate of one group of workers with output constant might reduce employment of one or more other groups of workers as well as that of the workers whose wage rate has increased." (Hamermesh 1993, p.36)

The own- and cross-partial elasticities of factor price are characterized by $\varepsilon_{i j}=\delta \ln w_{i} / \delta \ln X_{j}$, with respect to a change in the quantity $X_{j}$. When $\varepsilon_{i j}<0$ for $j \neq i$ : 
(...) an exogenous increase in the quantity of input $j$ reduces the price of input $i$ at a constant marginal cost. For example, an influx of new immigrants into a labor market must raise the wage rate of at least one other group of workers, or increase the rate of return to capital; but it could lower the wage received by some other group of workers (presumably a group that competes for jobs with the new immigrants) (Hamermesh 1993, p.37).

\section{Complementarity and substitution}

To understand the complementarity and substitution between inputs, some considerations have to be made. In order to attain a given level of production, conditional demands are the quantities of each input that a firm wants to utilize. In order to maximize its profit, unconditional demands are the quantities of each input that a firm wants to use.

Such as proposed by Cahuc and Zylberberg (2004), let the production function of the firm be $F(K, L)$, where $K$ is capital, energy, and raw materials (referred below only as capital); and $L$ represents a single aggregate of labor. On one hand, if in a given level of output $(Y)$, capital and labor always have to be combined in the same proportion, capital and labor are complementary. In other words, the ratio $K / L$ remains a constant independent of $Y$. Labor and capital are gross complements if an increase in the price of a factor implies a reduction in the unconditional demand for both labor and capital. Two factors are $p$ complements if the conditional demand for one of them decreases if the cost of the other factor rises. On the other hand, if capital and labor can be combined in different proportions to reach a certain production level $(Y)$, then they are substitutable. Labor and capital are gross substitutes when an increase in the price of a factor leads the firm to reduce the unconditional demand for this factor and increase the demand for the other. Two factors are $p$-substitutes if the conditional demand for one of them increases when the cost of the other factor increases. If the production function has only two inputs, then they are inevitably p-substitutes. 
Using the partial elasticities of demand and of factor prices, as well as different terms based on whether factor prices $(p)$ or quantities $(q)$ are experiencing exogenous changes, the relationships within pairs of factor inputs can be classified. For partial elasticities of labor demand ( $\eta_{i j}$, factor price is exogenous), if $\eta_{i j}<0$, inputs $i$ and $j$ are $p$ complements; if $\eta_{i j}>0$, they are $p$-substitutes. All input pairs $(i, j)$ can be $p$-substitutes, but if one pair is p-complement, the problem is more interesting. For partial elasticities of factor

price ( $\varepsilon_{i j}$, quantity is exogenous), if $\varepsilon_{i j}>0$, inputs $i$ and $j$ are $q$-complements; if $\varepsilon_{i j}<0$, they are $q$-substitutes. All input pairs $(i, j)$ can be $q$-complements, but the motivation happens when at least one pair is q-substitute.

Some examples may help demonstrate the use of these definitions. If educated and uneducated workers are $p$-substitutes, one may infer that a rise in the cost to employers of employing the low-wage, uneducated labor, perhaps resulting from an increase in the minimum wage, will increase the fraction of educated workers used at each level of production. These two factors may also be $q$-complements. If so, an increase in the relative supply of educated workers (perhaps resulting from increased awareness of the non-pecuniary benefits of acquiring a college education) will raise the relative wage of uneducated workers by making them relatively more productive (Hamermesh 1993, p.38).

\section{Effects of education and demographic shocks on elasticities of labor demand and factor price}

Such as discussed by Hamermesh (1993, chapter 3) unskilled workers are easier to substitute for capital than skilled labor. In other words, own-price elasticities of labor demand are greater for unskilled than for skilled workers. In this way, capital and skill are p-complements, in which $p$-substitution for capital is greater for less-educated workers. On the other hand, own-quantity elasticities of factor-price are greater for highly educated workers.

Considering previous studies, Hamermesh indicates that: 
(...) it seems fairly safe to conclude that additional education reduces the degree of $p$-substitutability of labor with capital services and reduces the labor-demand elasticity. There is strong evidence for capital-skill $p$-complementarity (and relative $q$-substitutability). (...) [Moreover] both capital deepening and more rapid installation of newer capital equipment raise the share of more educated labor.

These suggest that educated labor is relatively more $q$-complementary with capital and with newer technology than unskilled labor (Hamermesh 1993, p.117).

Some studies have been considering the effects of how changes in population and the demographic structure of the labor force affect relative wages. The interest has been on evaluating the influence of increasing female labor-force participation, as well as changing the relative supply of young workers on their own wages and employment, and on that of other groups. Influences of minimum wage and other policies on the employment of younger workers have also been analyzed. Important studies in the United States have also been done on how alterations in immigration patterns affect the wages and employment of native workers (Hamermesh 1993).

An interesting aspect of the impact of exogenous changes in population structure on wage rates is the finding that changes in the relative supply of one group does not significantly affect wages of workers in other groups, as has been elucidated by small crosselasticities of complementarity in almost all pairs of groups. The implication of studies in the United States is that increases of female labor force participation, younger workers, or even skilled workers in the labor force do not have large effects on the relative wages of other groups (Hamermesh 1993). Finally, large changes in the labor-force cohort size significantly affect earnings of the cohort, but in a small manner, such as have been shown by weak own-quantity elasticities in previous studies (Welch 1979; Berger 1985).

Evaluating the impact of immigrants that entered the United States between 1980 and 2000 on wage, Borjas (2003) estimates factor-price elasticities that require information on factor shares, and hold marginal cost, capital stock and quantities of other factors constant. Borjas evaluates: (1) own-factor price elasticities, giving the wage impact of an 
increase in the supply of workers with education $i$ and experience $j$; (2) cross-factor price elasticities within an education group, giving the impact on the wage of group $(i, j)$ of an increase in the supply of group $\left(i, j^{\prime}\right)$, with $j \neq j j^{\prime}$; and (3) cross-factor price elasticities across education groups, giving the impact on the wage of group $(i, j)$ of an increase in the supply of group $\left(i^{\prime}, j^{\prime}\right)$, with $i \neq i$ ' and $j=(1, \ldots, j, \ldots 8)$. Borjas' main finding is that:

(...) the large immigrant influx of the 1980s and 1990s adversely affected the wage of most native workers, particularly those workers at the bottom and top of the education distribution. The wage fell by 8.9 percent for high school dropouts and by 4.9 percent for college graduates. In contrast, the wage of high school graduates fell by only 2.6 percent, while the wage of workers with some college was barely affected. Overall, the immigrant influx reduced the wage of the average native worker by 3.2 percent (Borjas 2003, p.1368).

This result is in opposition to previous ones, because it suggests that wage and labor supply of competing native labor force is affected by immigration flows.

\section{SPECIFICATION OF DEMAND SYSTEMS}

After aggregating the microdata by micro-region, age-education, and year cells, as well as getting information on mean income and number of men in each cell, and proportion of men in each age-education group by year and micro-region, fixed-effects models were generated using the following formulations.

Let $W$ be the logarithm of wages and $X$ be an independent variable or vector of independent variables. Let $i$ denote a micro-region, $t$ denote time (Census year), and $c$ denote a cell (an age-education group). The simplest model is:

(1) $W_{i t c}=\beta_{0 c}+\beta_{1} X_{i t c}+v_{i c}+\theta_{t c}+\varepsilon_{i t c}, i=1, \ldots, K ; t=1, \ldots, T$,

where $v_{i}$ is a vector of area fixed effects and $\theta_{t}$ is a vector of time fixed effects. $\beta_{1}$ estimates the impact of idiosyncratic variations in relative endowments of labor classified by age and education on wage rates. The formulation in (1) restricts each own-quantity 
effect (essentially an elasticity of factor prices) to be independent of variations in the relative sizes of the other eleven age-education groups. Equation (1) might be estimated as twelve different regressions, one for each age-education cell; instead, all twelve are pooled and estimated (1) in a single regression, including the proportions of people in each of the age-education groups, eleven indicators for age-education groups, and three for Census years. The reference group is workers ages 15-24 with zero to four years of schooling observed in the 1970 Census. An even simpler version of (1) would exclude both area and time fixed effects.

Model (1) is highly restrictive in setting all cross-quantity effects to zero. An approach that allows for cross-quantity effects, and thus accords more closely with theory by explicitly allowing labor-labor substitution (Hamermesh 1993, chapter 2), is:

(2) $W_{i t c}=\beta_{0}+\beta_{1} X_{i t c}+\beta_{2} X_{i t c^{\prime}}+v_{i}+\theta_{t}+\varepsilon i t c, i=1, \ldots, K ; t=1, \ldots, T$,

where $c$ ' refers to the other age-education cells. This formulation - a complete system of inverse labor-demand equations - allows for substitution parameters that indicate how a change in the fraction of the population in one cell alters the wage of people in any other cell. Equation (2) contains ten terms in $X_{i t c}$. A pooled version is estimated including all cross-proportions of people for each of the twelve age-education groups (11x12=132 coefficients), eleven indicators for age-education groups, and three indicators for Census years. Of course, one could estimate both (1) and (2) without the area and time fixed effects, but that restriction is not imposed anywhere in the material presented here.

Some of the restrictive assumptions in (1) and (2) can be relaxed still further. First, the production parameters can be allowed to vary over time. With this relaxation (1) becomes:

(1') $W_{i t c}=\beta_{0}+\beta_{1} X_{i t c}+\beta_{3} \theta_{t} X_{i t c}+v_{i}+\theta_{t}+\varepsilon_{i t c}, i=1, \ldots, K ; t=1, \ldots, T$. 
This specification interacts the $X$ variables with the time indicators and allows testing whether the own-elasticities of factor price are unchanged over time. As such, (1') nests the simpler specification (1). The pooled version of (1') has twelve proportions of people in each one of the age-education groups, eleven indicators for age-education groups, three for Census years, and interactions between proportions and year indicators $(12 \times 3=36$ coefficients).

A model analogous to (2) that allows all the substitution parameters to vary over time by adding both own-quantity interactions with the $T-1$ time indicators and interactions of the cross-quantity terms with those indicators is:

(2') $W_{i t c}=\beta_{0}+\beta_{1} X_{i t c}+\beta_{2} X_{i t c}{ }^{\prime}+\beta_{3} \theta_{t} X_{i t c}+\beta_{4} \theta_{t} X_{i t c}{ }^{\prime}+v_{i}+\theta_{t}+\varepsilon_{i t c}, i=1, \ldots, K ; t=1, \ldots, T$.

Note that (2') nests each of Equations (1), (2) and (1'). The pooled form of (2') can be estimated in a single regression, including all cross-proportions of workers for each ageeducation group and their interactions with the time indicators. In all four of these models one could expand the specifications still further by allowing for time-varying area fixed effects. This re-specification controls for changing area-specific effects. Re-estimates of all four equations suggest that this alternative did not affect the demand parameters on which this study is focused. The pooled equation of (2') includes all cross-proportions of people for each of the twelve age-education groups $(11 \times 12=132$ coefficients), eleven indicators for age-education groups, three for Census years, and interactions between crossproportions and year indicators $(132 \times 3=396$ coefficients $)$.

Less general formulations of Equations (1') and (2') would simply take a continuous time indicator, TIME, going from 1 to $T$, and interact it instead of each of the dummies $\theta_{t}$ with the $X_{i t c}$ in Equation (1) and with $X_{i t c}$ and $X_{i t c}$ in Equation (2). Those formulations implicitly allow for linear trends in the production parameters. 
The most general formulations that make sense would take Equations (1') and (2') and allow for the possibility of area-specific trends $\left(v_{i}\right)$ in the production parameters. Thus one might generalize still further and estimate:

(1") $W_{i t c}=\beta_{0}+\beta_{1} X_{i t c}+\beta_{3} T I M E_{t} X_{i t c}+\beta_{5 v_{i}} T I M E_{t} X_{i t c}+v_{i}+\theta_{t}+\varepsilon_{i t c}, i=1 \ldots K ; t=1 \ldots T$.

Here one might even like to allow for time-specific and area-specific production parameters by interacting the $X_{i t c}$ with the vector $\theta_{t}$ instead of with the continuous variable TIME in Equation (1"). That could be done; but such an extensive formulation means estimating separate production parameters for each area $\left(v_{i}\right)$ in each time period $\left(\theta_{t}\right)$, something that is not likely to be very productive. As it is, the formulation in Equation (1") implies that there are separate production parameters for each area, but that in each area the production parameter is characterized by a linear trend. Of course, one would use this and (1') to test for the significance of the $\beta 5$, the area-specific trends in the production parameters.

Finally, one can take the same track with the more general versions in Equations (2) and (2') and estimate:

(2') $W_{i t c}=\beta_{0}+\beta_{1} X_{i t c}+\beta_{2} X_{i t c}{ }^{\prime}+\beta_{3} T I M E_{t} X_{i t c}+\beta_{4} T I M E_{t} X_{i t c}{ }^{\prime}+\beta_{50 i} T I M E_{t} X_{i t c}+$ $\beta 6 v_{i} T_{I M E} X_{i t c}{ }^{\prime}+v_{i}+\theta_{t}+\varepsilon i t c, i=1 \ldots K ; t=1 \ldots T$.

This formulation allows for time trends in area-specific production parameters describing both own- and cross-substitution effects.

Throughout this series of specifications, the analysis has moved from the simplest formulation, Equation (1) excluding area or time fixed effects, to increasingly general formulations. Each complication allows us to test the validity of the restrictions imposed in earlier specifications. Even the most complex specification (2') is not as general as it could be were still better data available. There is no a priori reason to specify constant marginal cost, but it is implicit in the formulations here and is necessitated by the absence 
of any information on the scale of production in each area. Similarly, if there were measures of capital stocks available by area (Grant and Hamermesh 1981), the implicit assumption of separability of the examined inputs from capital could be removed by the inclusion of capital stocks information in the model. 


\section{Chapter 5. Descriptive statistics and estimates}

\section{DESCRIPTIVE ANALYSIS}

As discussed above, the age distribution of the population of Brazil has been changing rapidly. Figure 3.1, based on UN estimates and projections, shows the evolution of the child and old-age dependency ratios from 1950 to 2050 . The child dependency ratio has fallen dramatically, and will continue to decrease significantly in the next decades. However, the old-age dependency ratio has been increasing since 2000, and will increase even more in coming years. These patterns are related to the decline in the total fertility rate since the 1960s (Table 3.1). Since fertility declined so abruptly, the shares of younger age groups also declined.

Differences in the timing and speed of the fertility transition led to substantial temporal variations in the age distribution across regions, states and municipalities. Figures 5.1 to 5.12 illustrate the proportion of males in twelve age-education groups in all 502 Brazilian micro-regions for 1970-2000 Censuses. In order to calculate these proportions, only males ages 15-64 were considered in the denominator for each year and micro-region. For a better understanding of the figures, micro-regions are ordered by five Brazilian regions: North (NO), Northeast (NE), Southeast (SE), South (SO) and Center-West (CW).

Figures 5.1, 5.4, 5.7 and 5.10 demonstrate proportions of males in the lowest education group in four different age groups. In general, these figures show that the proportion of males with zero to four years of schooling has been decreasing in all microregions. This decline is greater for the youngest group (15-24), young adults (25-34) and adults (35-49), but also noticeable for mature adults (50-64). Areas in the Southeast and South of Brazil show a greater decrease in the proportion of men in low-educated groups than do the North and Northeast. 
Figures 5.2, 5.3, 5.5, 5.6, 5.8, 5.9, 5.11 and 5.12 demonstrate the proportion of males with five to eight years of schooling, and at least nine years of schooling. There is a clear increase over time in the proportion of males with higher educational attainment. At the same time, differences among micro-regions are pronounced and persistent. Higher proportions in these age-education groups are observed in the Southeastern, Southern, and Center-Western areas, compared to Northern and Northeastern areas.

Figure 5.1. Proportion of Men Ages 15-24 with 0-4 Years of Schooling in 502 Microregions, 1970-2000.
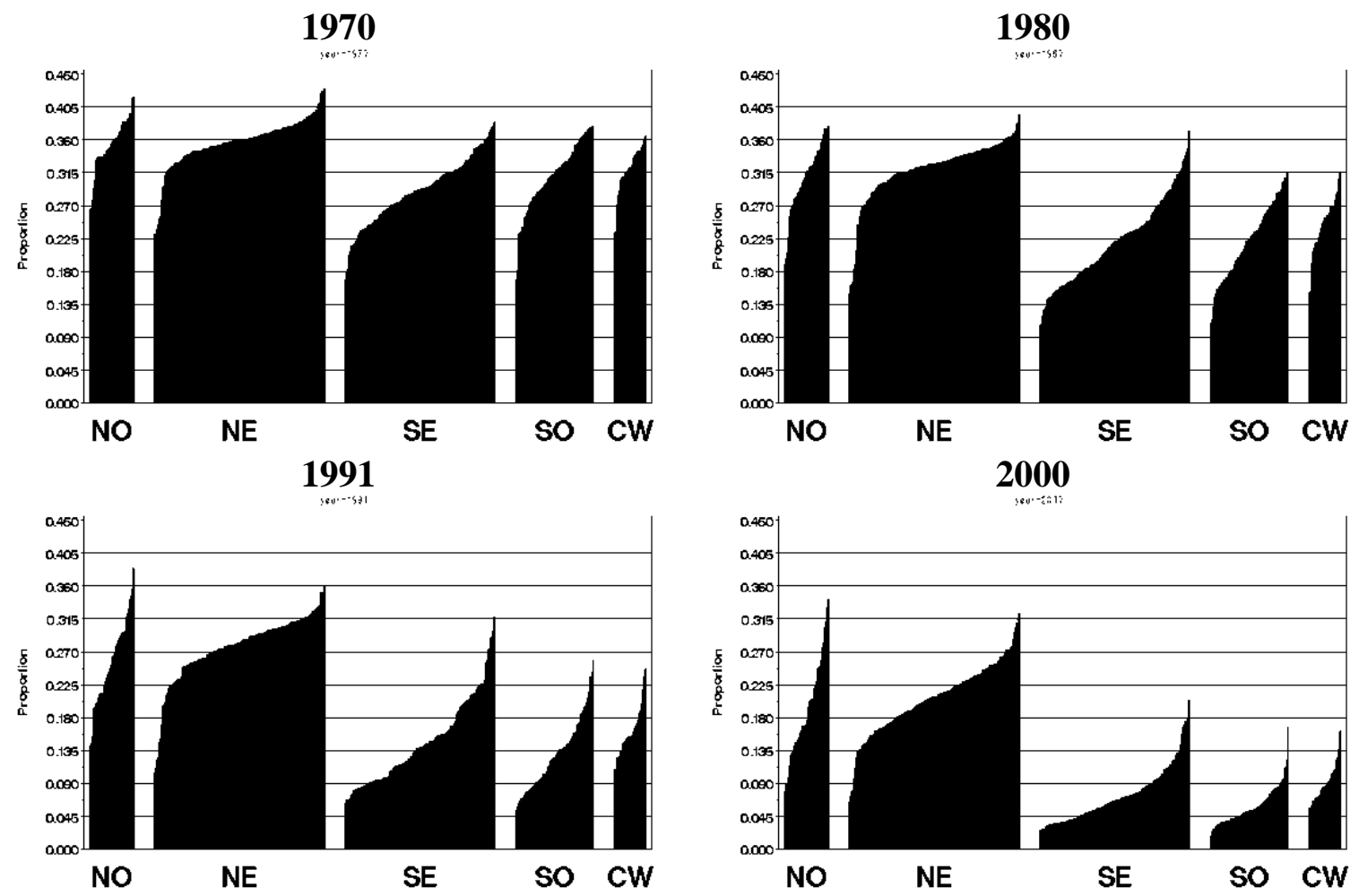

Source: 1970-2000 Brazilian Censuses. 
Figure 5.2. Proportion of Men Ages 15-24 with 5-8 Years of Schooling in 502 Microregions, 1970-2000.
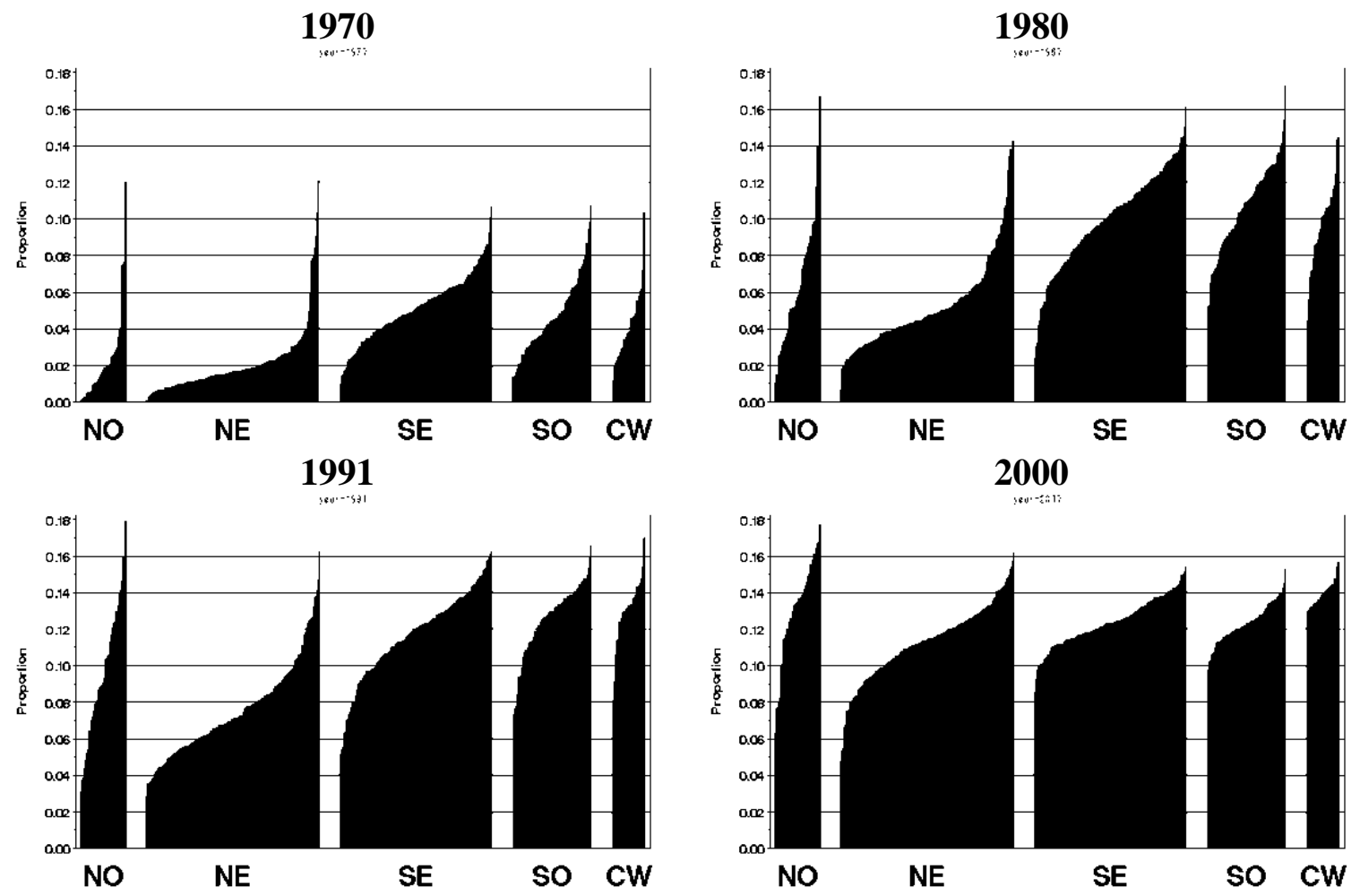

Source: 1970-2000 Brazilian Censuses.

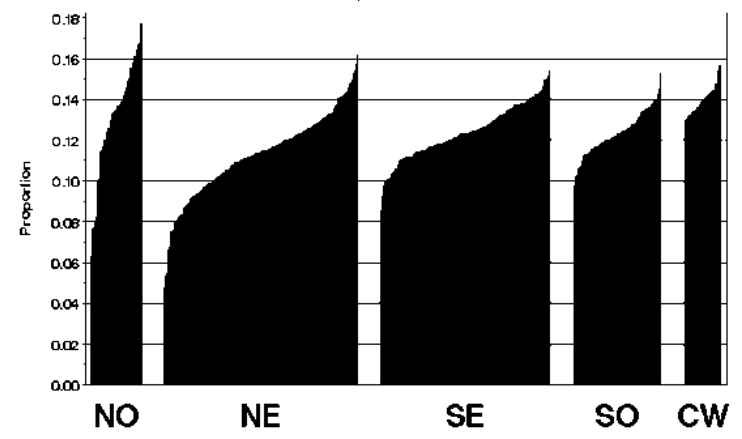


Figure 5.3. Proportion of Men Ages 15-24 with 9+ Years of Schooling in 502 Microregions, 1970-2000.
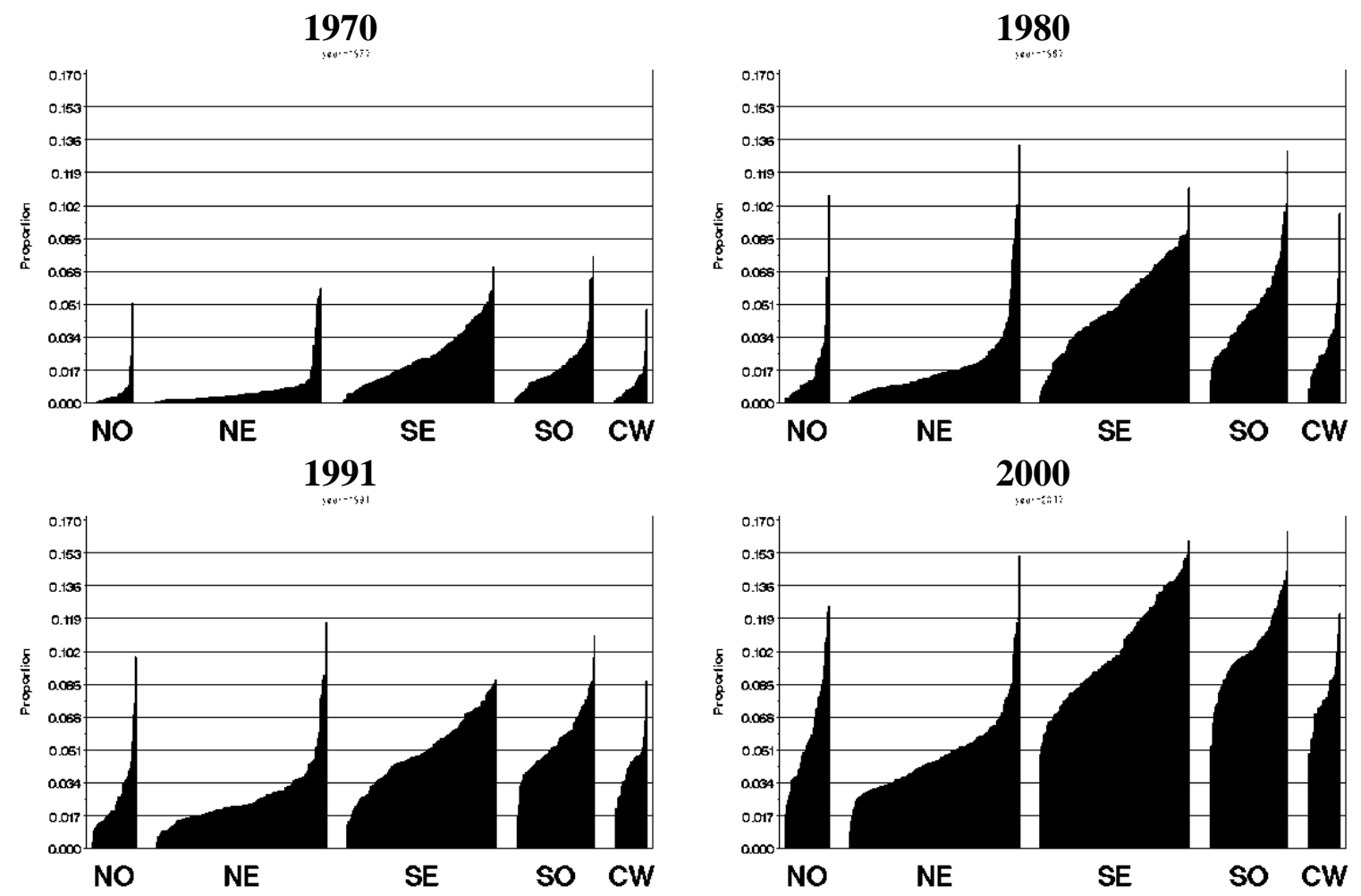

Source: 1970-2000 Brazilian Censuses.

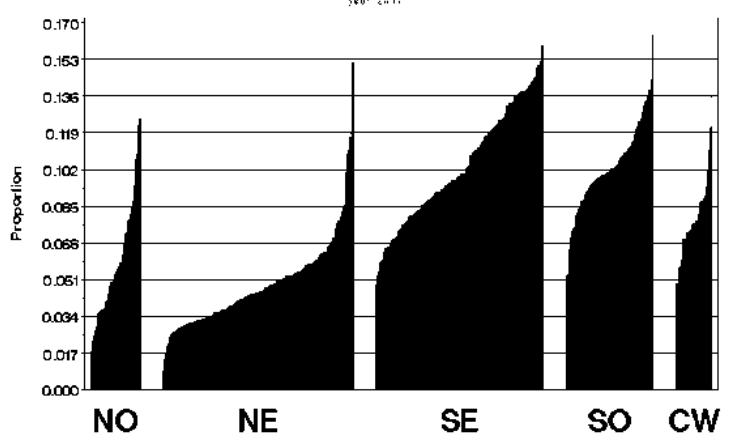


Figure 5.4. Proportion of Men Ages 25-34 with 0-4 Years of Schooling in 502 Microregions, 1970-2000.
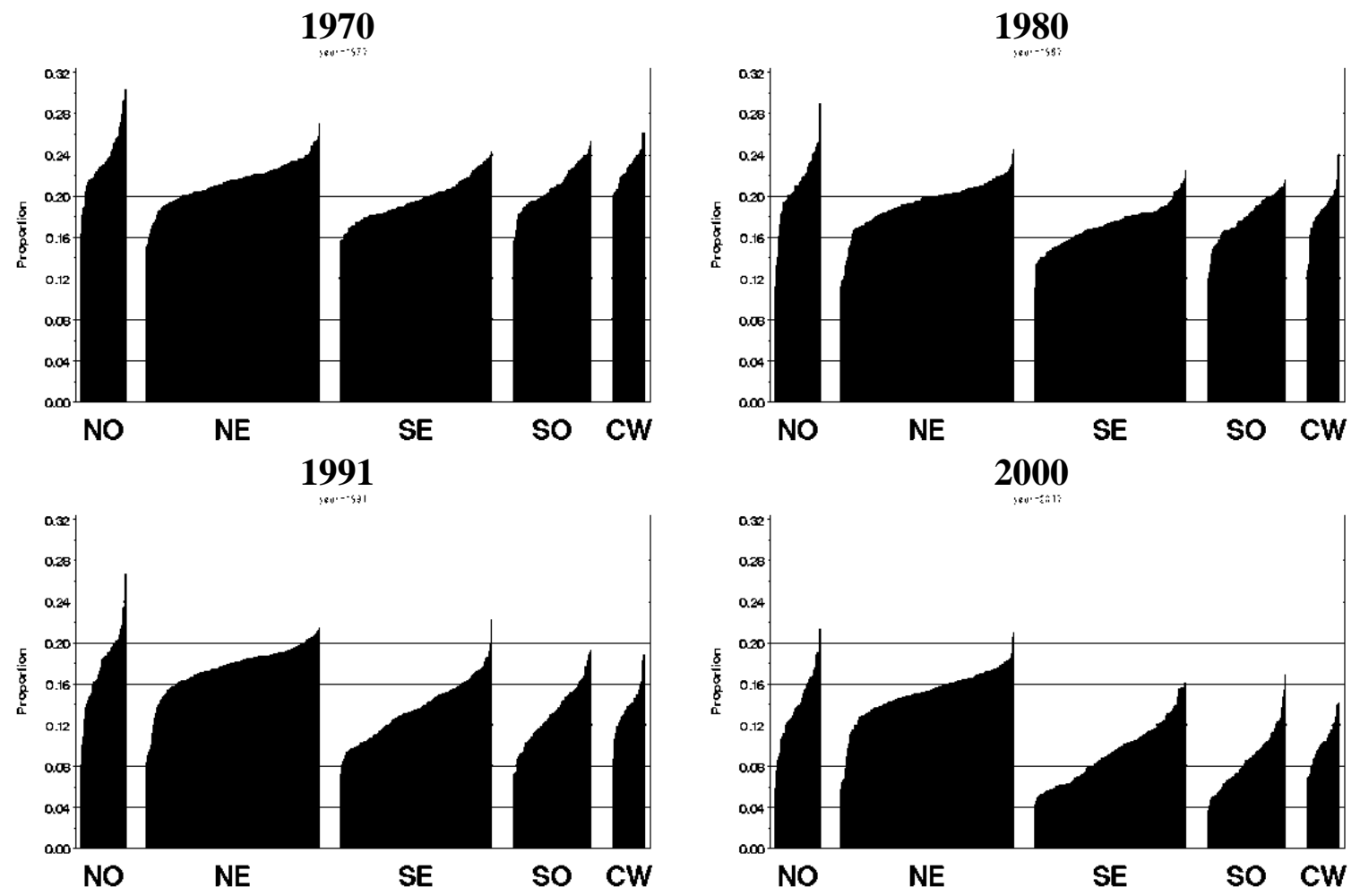

Source: 1970-2000 Brazilian Censuses. 
Figure 5.5. Proportion of Men Ages 25-34 with 5-8 Years of Schooling in 502 Microregions, 1970-2000.
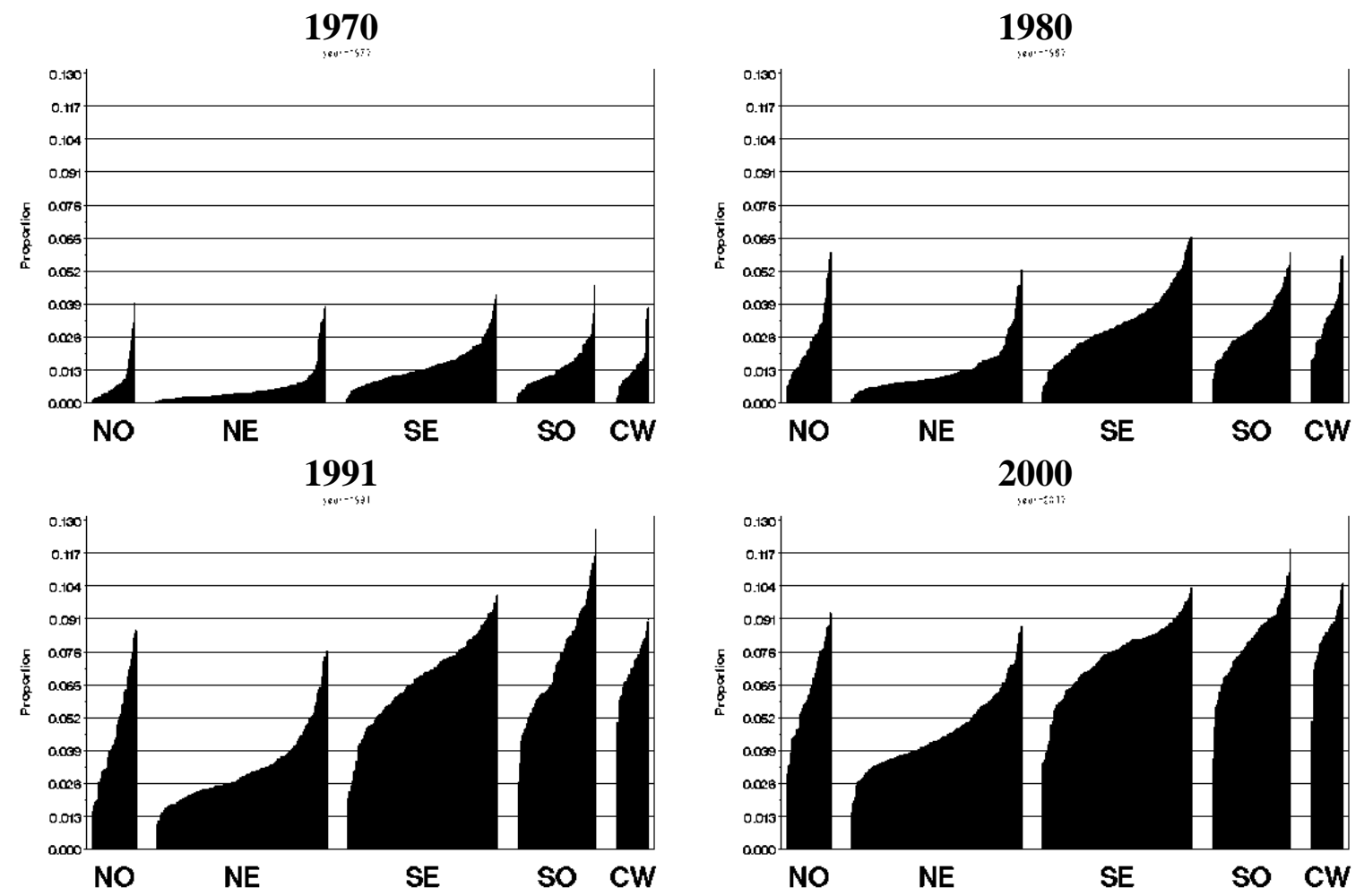

Source: 1970-2000 Brazilian Censuses.

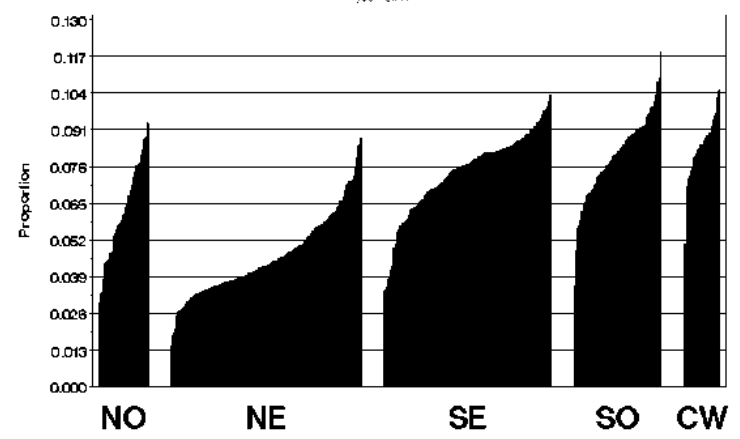


Figure 5.6. Proportion of Men Ages 25-34 with 9+ Years of Schooling in 502 Microregions, 1970-2000.
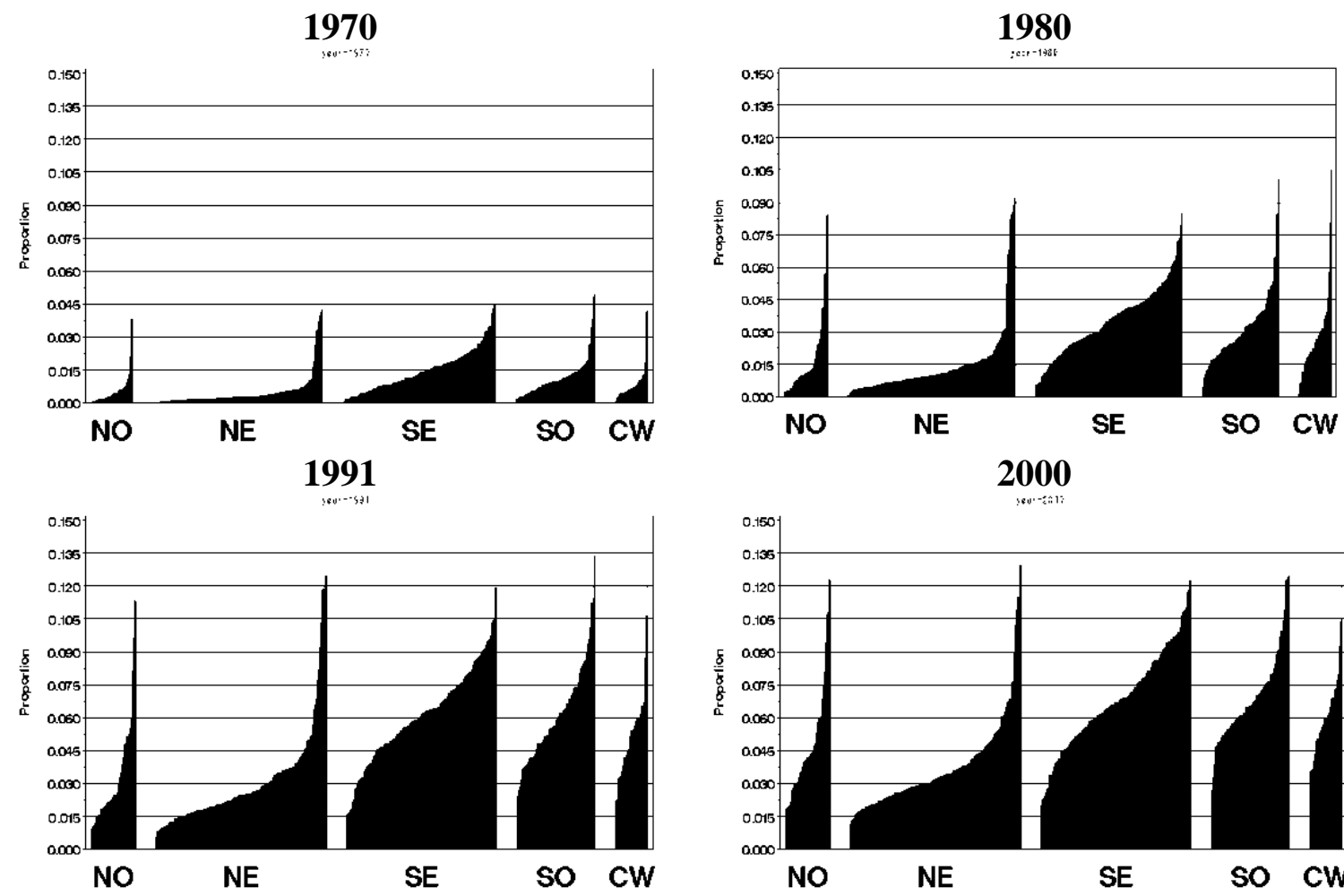

Source: 1970-2000 Brazilian Censuses.

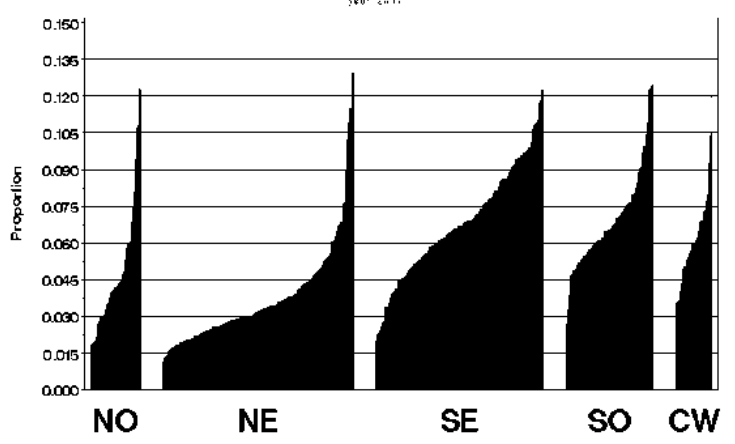


Figure 5.7. Proportion of Men Ages 35-49 with 0-4 Years of Schooling in 502 Microregions, 1970-2000.
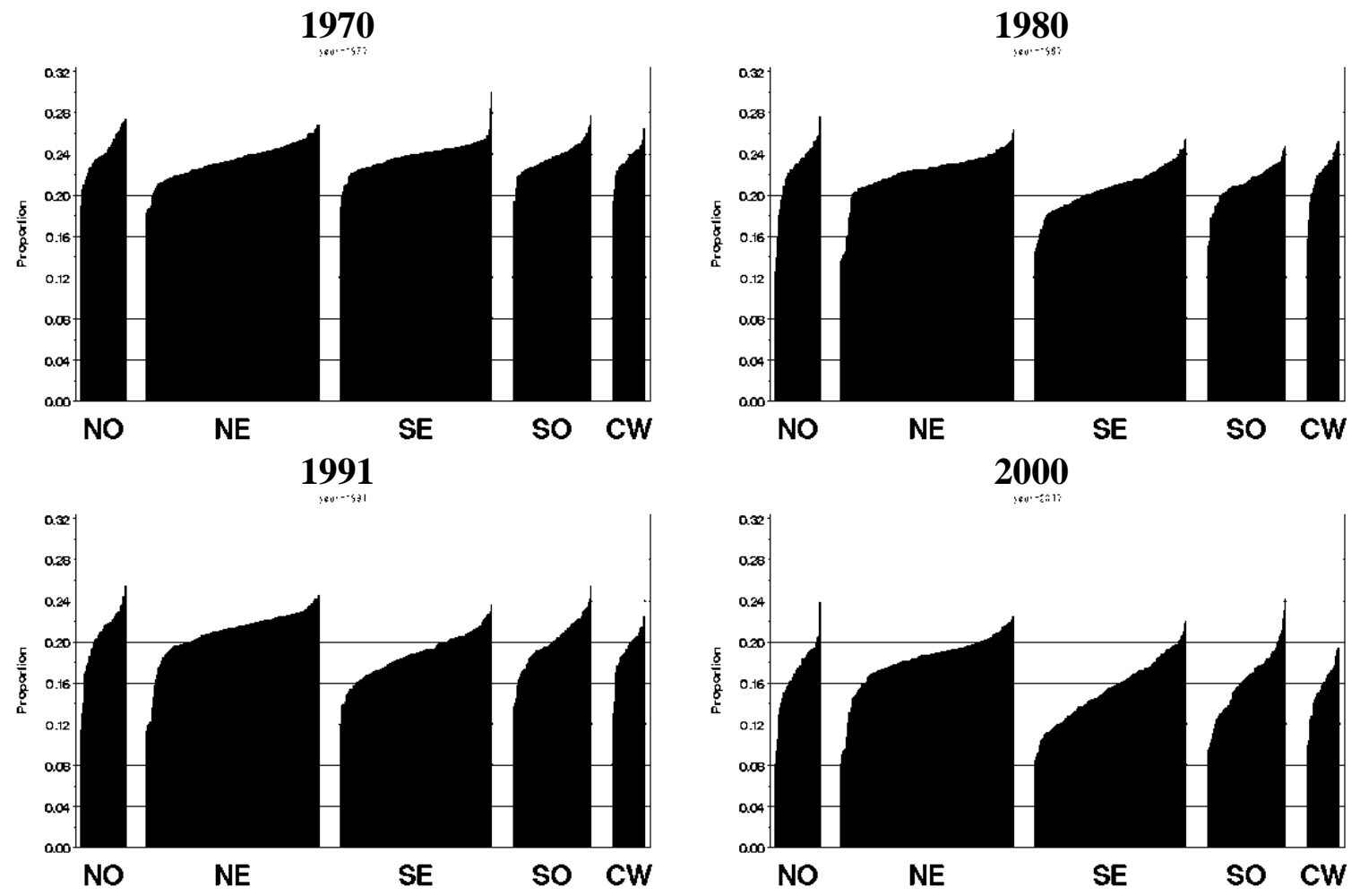

Source: 1970-2000 Brazilian Censuses. 
Figure 5.8. Proportion of Men Ages 35-49 with 5-8 Years of Schooling in 502 Microregions, 1970-2000.
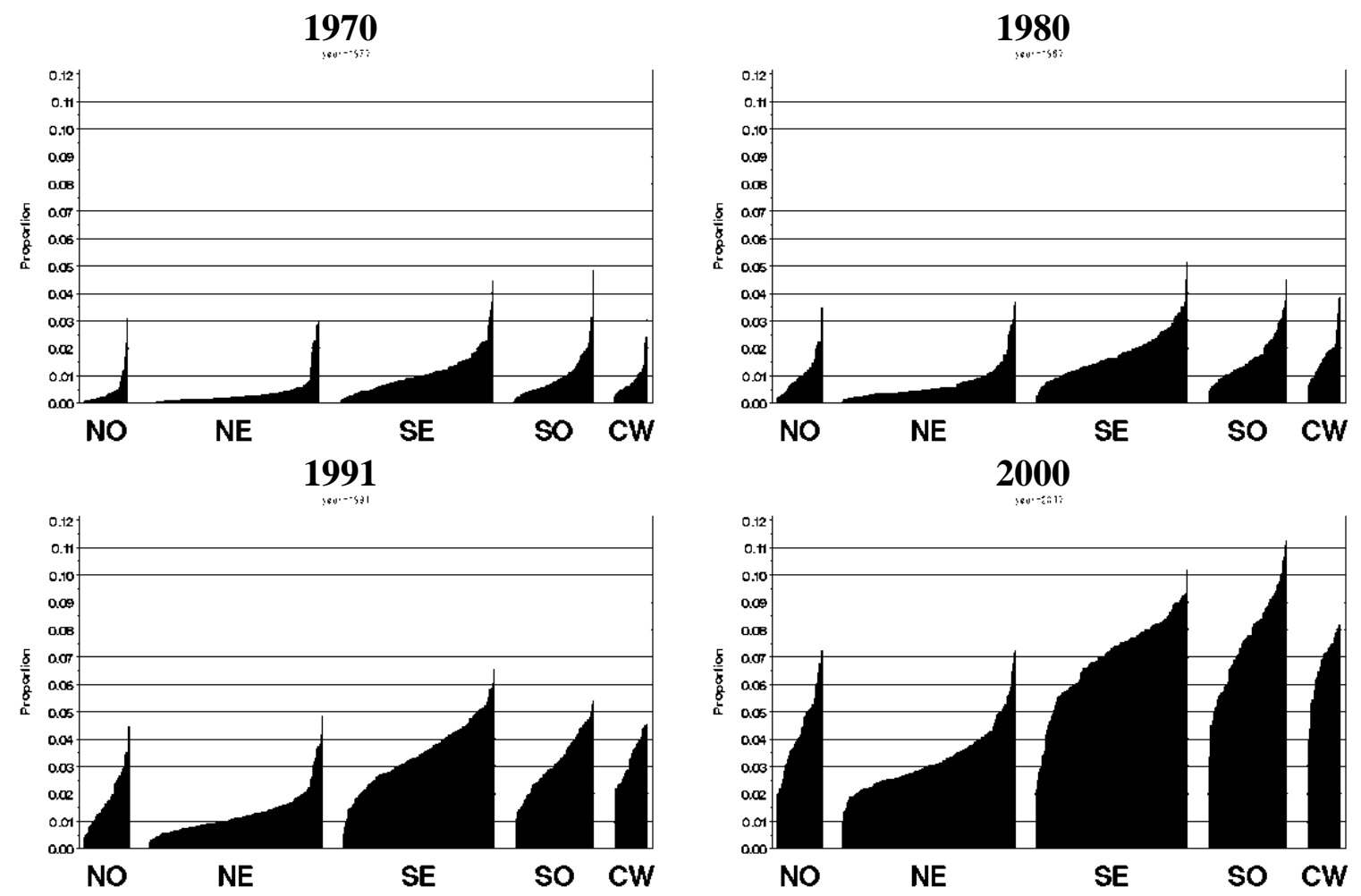

Source: 1970-2000 Brazilian Censuses.

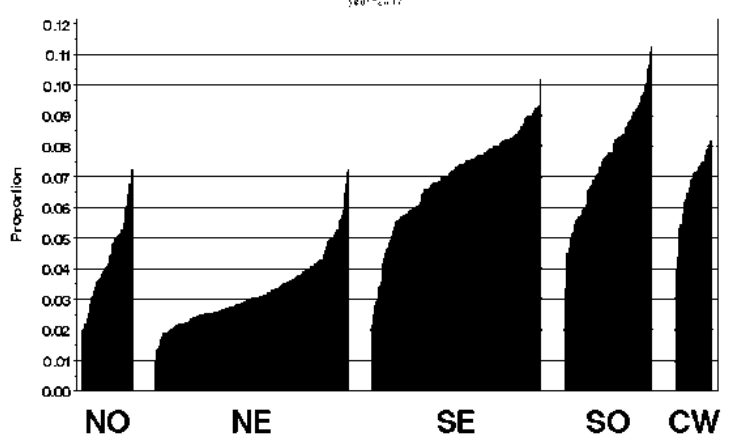


Figure 5.9. Proportion of Men Ages 35-49 with 9+ Years of Schooling in 502 Microregions, 1970-2000.
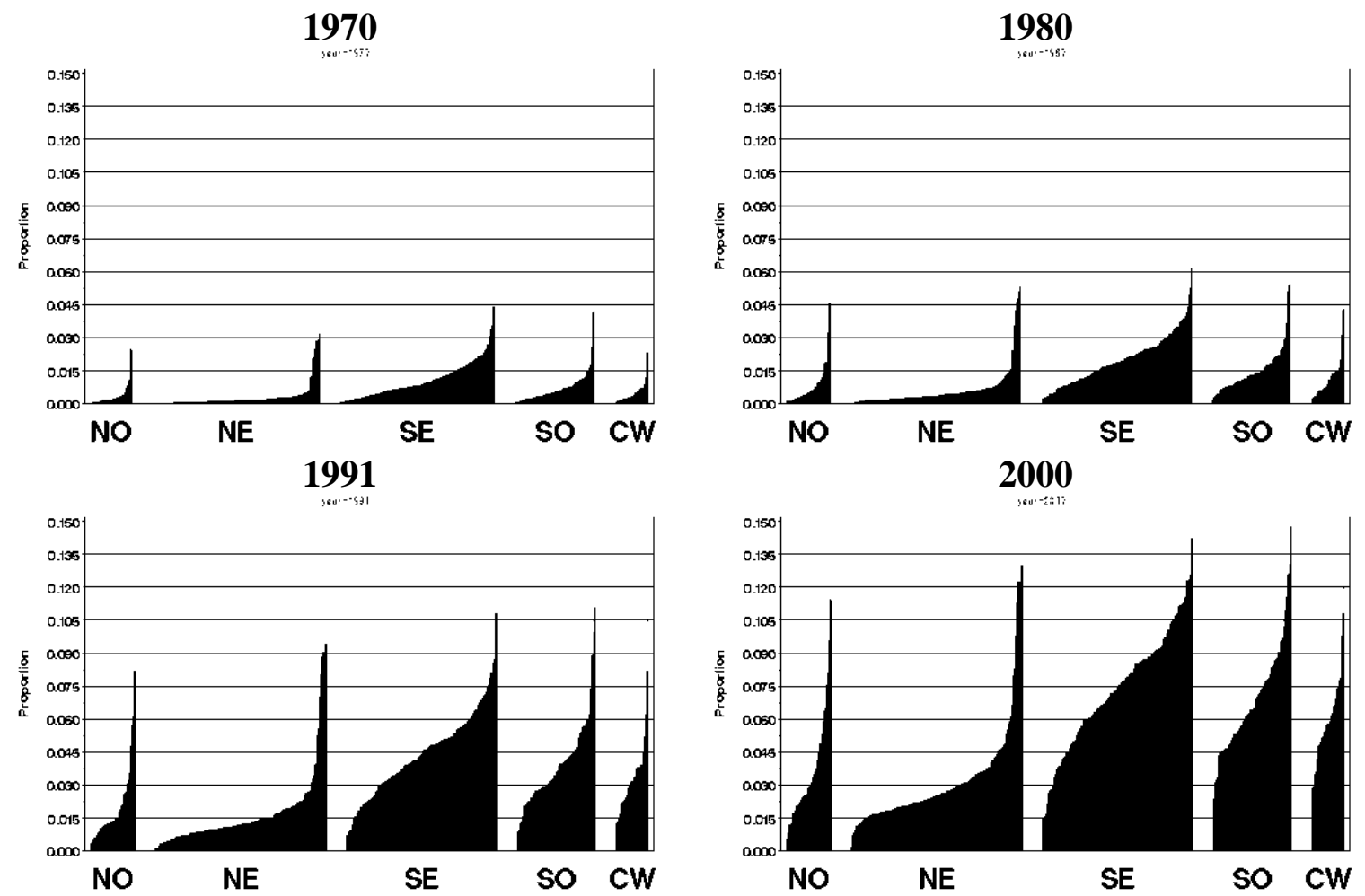

Source: 1970-2000 Brazilian Censuses.

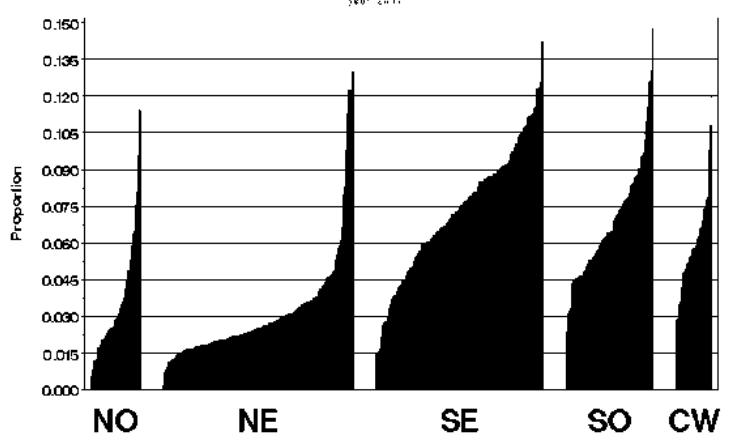


Figure 5.10. Proportion of Men Ages 50-64 with 0-4 Years of Schooling in 502 Microregions, 1970-2000.
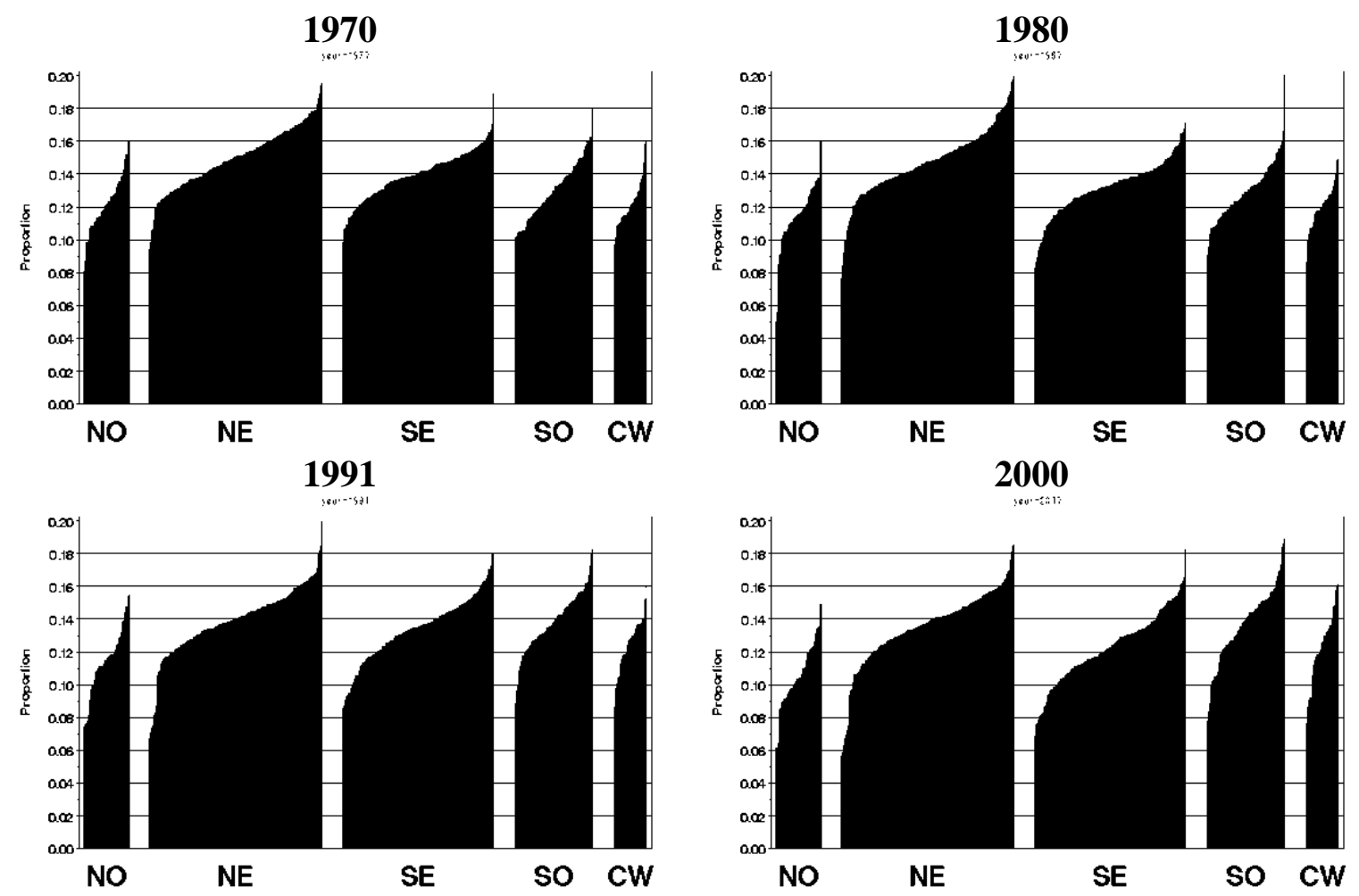

Source: 1970-2000 Brazilian Censuses. 
Figure 5.11. Proportion of Men Ages 50-64 with 5-8 Years of Schooling in 502 Microregions, 1970-2000.
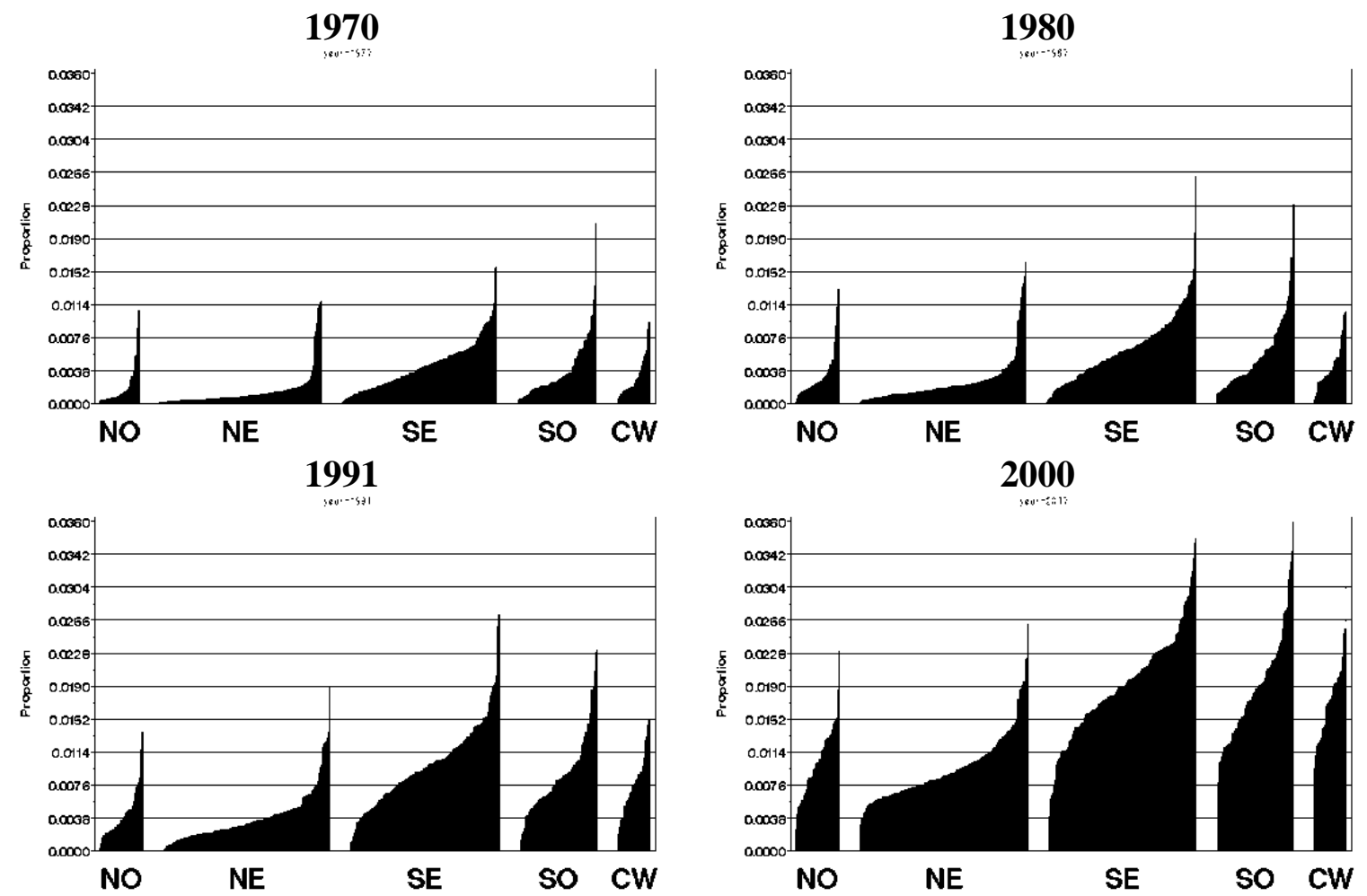

Source: 1970-2000 Brazilian Censuses.

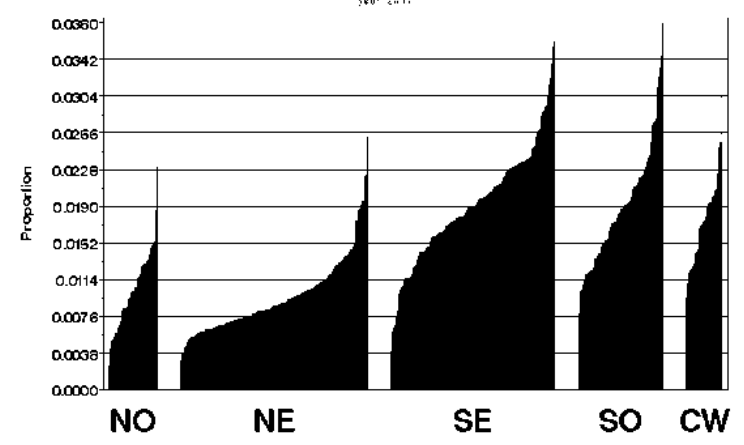


Figure 5.12. Proportion of Men Ages 50-64 with 9+ Years of Schooling in 502 Microregions, 1970-2000.
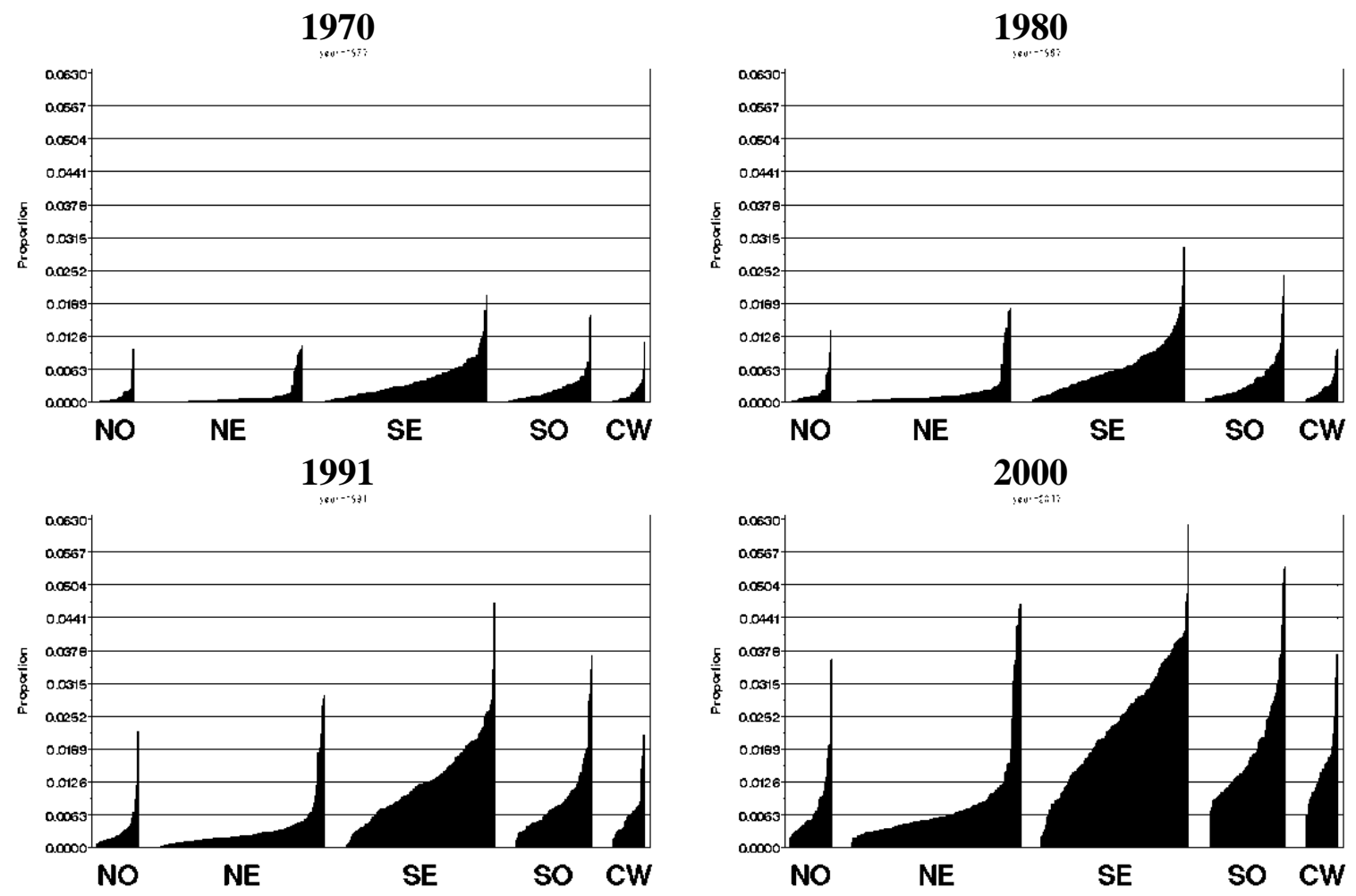

Source: 1970-2000 Brazilian Censuses.

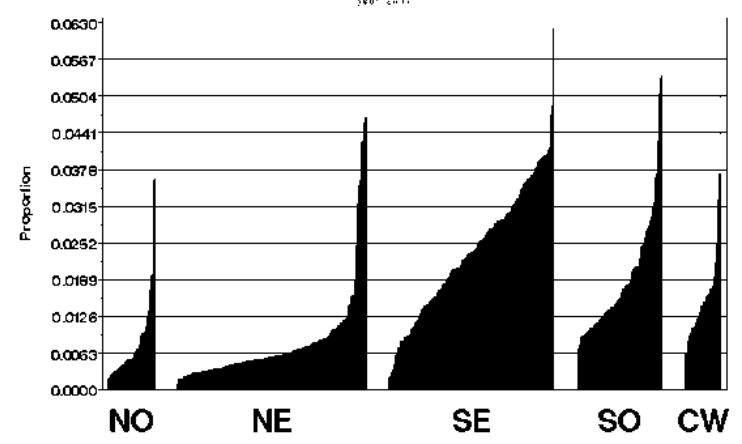


Figures 5.13 and 5.14 present the age distributions for 12 selected micro-regions in 1970 and 2000. (Data are shown only for these two years to allow a clearer picture of the changes.) The curves for the Northeastern micro-regions (in Piauí, Pernambuco, Ceará, Paraíba and Bahia) indicate that the age distributions in 1970 and 2000 were similar, unlike the Southeastern (Minas Gerais, Rio de Janeiro and São Paulo), the Southern (Paraná and Rio Grande do Sul) and the Center-Western (Goiás) micro-regions, where the proportions in the older age groups grew from 1970 to 2000.

Figure 5.15 and 5.16 illustrates the distribution of the male population by education for 1970 and 2000 for the same micro-regions. In general, the proportion of men with higher levels of schooling grew over the years. Furthermore, the Northeastern microregions have lower levels of education than the micro-regions in the South, Southeast and Center-West.

The changes in the distribution of educational attainment between the 1970 and 2000 Brazilian Censuses were substantial in all regions. Changes in the age distribution were also observed in the same period, at least in areas in the Southeast, South and CenterWest of the country. The crucial point is not only that there were profound demographic changes in Brazil over this period in both the age structure and educational attainment, but also that these proceeded at different rates in different parts of the country. These variations allow us to identify the labor-demand parameters, and thus to expand the study of the labormarket effects of the demographic dividend. Also, the persistent differences in levels suggest the need to use models that account for specific local factors through the use of fixed effects for micro-regions. 
Figure 5.13. Changes in the Age Distribution in Selected Micro-regions (Northeast), 1970 and 2000.
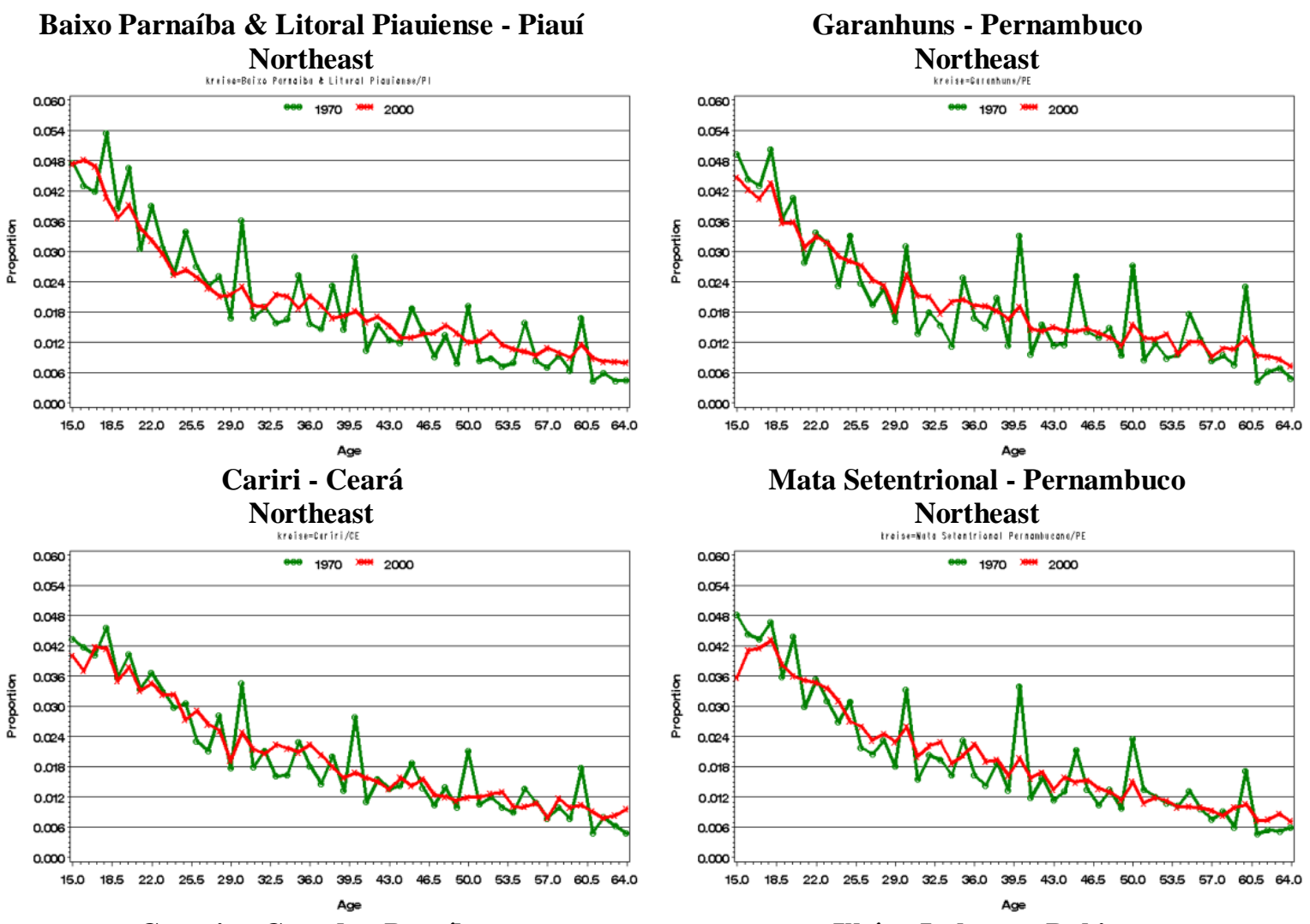

Campina Grande - Paraíba

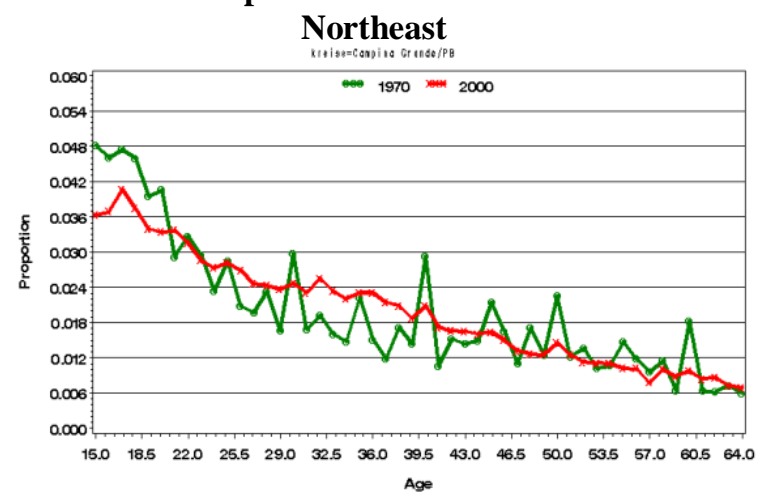

Ilhéus-Itabuna - Bahia

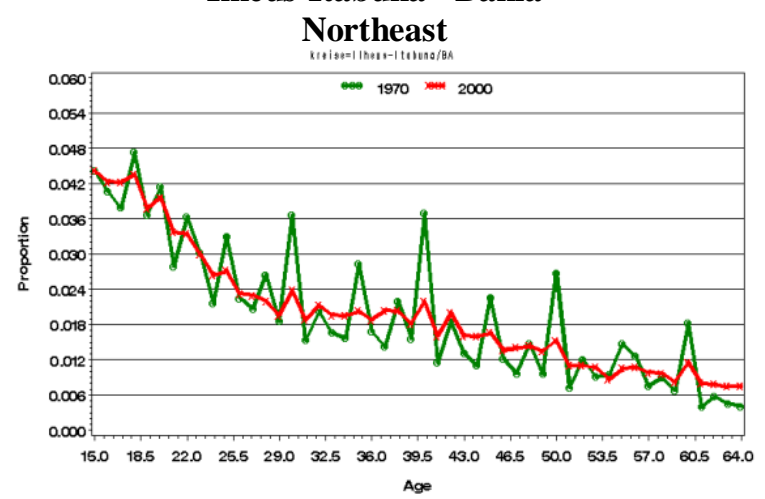

Source: 1970 and 2000 Brazilian Censuses. 
Figure 5.14. Changes in the Age Distribution in Selected Micro-regions (Southeast, South, Center-West), 1970 and 2000.

Uberlândia - Minas Gerais

Southeast

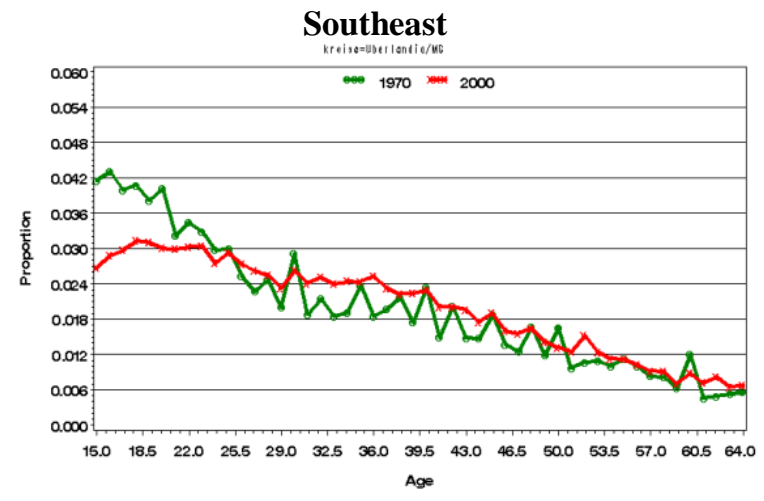

Volta Redonda - Rio de Janeiro

Southeast

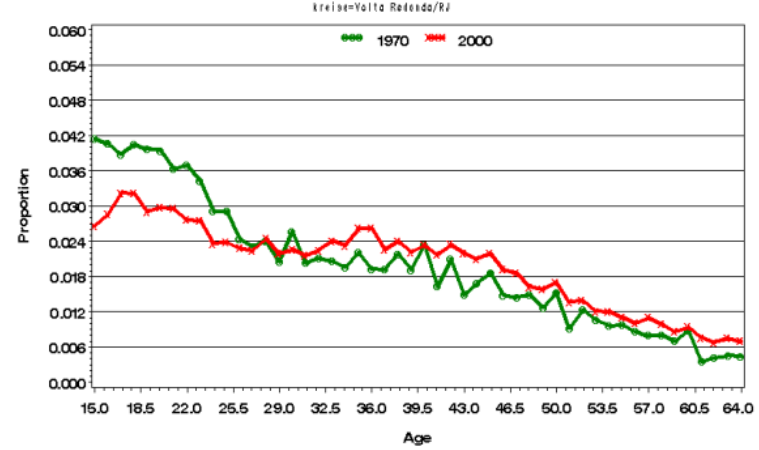

São José do Rio Preto - São Paulo Southeast

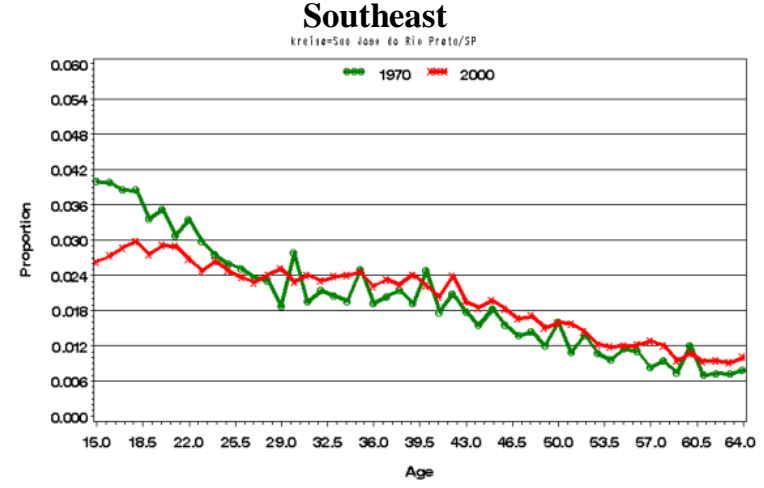

Source: 1970 and 2000 Brazilian Censuses.
Maringá - Paraná

South

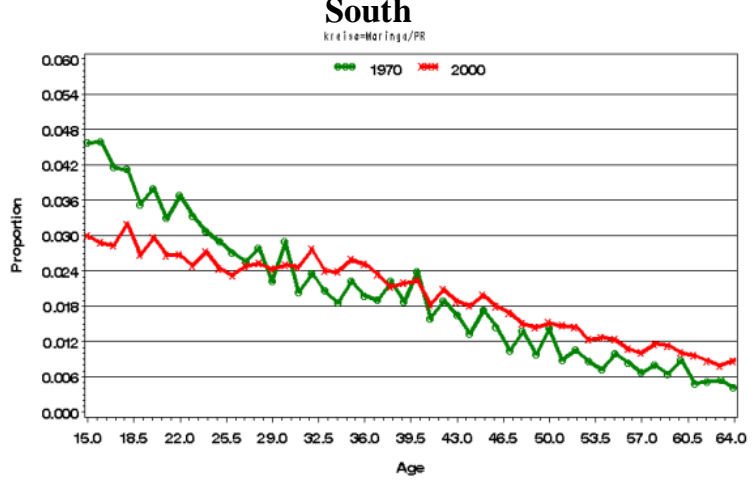

Porto Alegre - Rio Grande do Sul

South

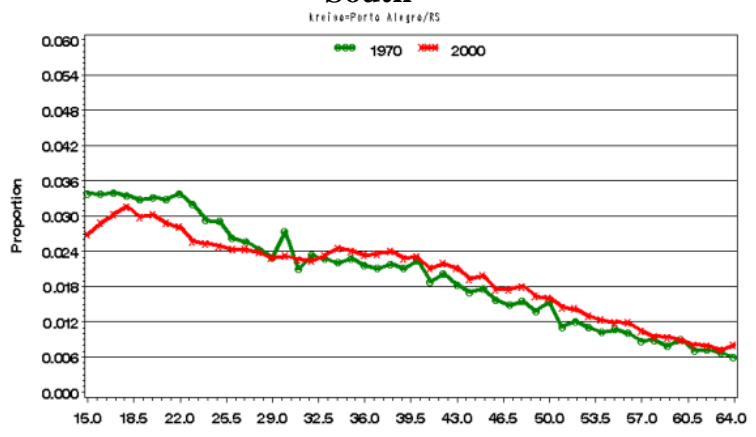

Age

Anápolis - Goiás Center-West

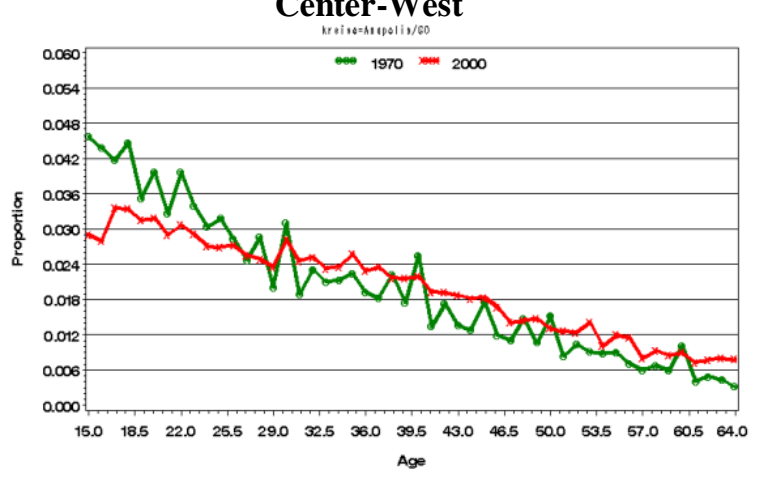


Figure 5.15. Changes in the Education Distribution in Selected Micro-regions (Northeast), 1970 and 2000.
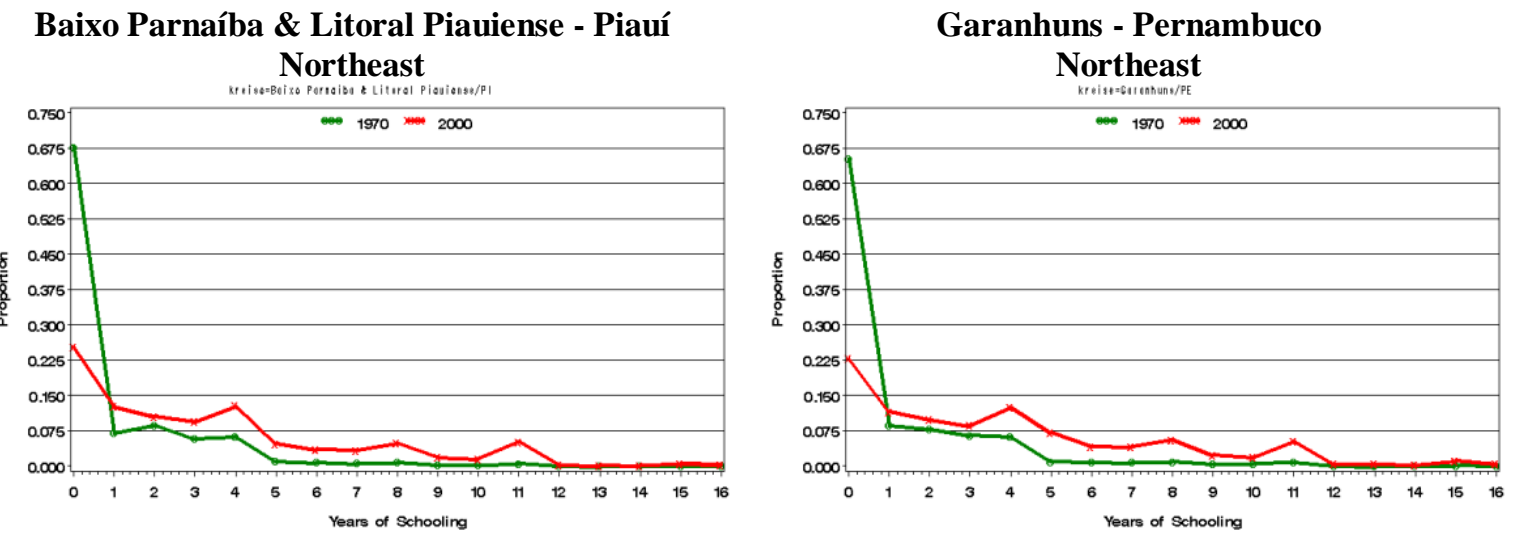

Cariri - Ceará

Northeast

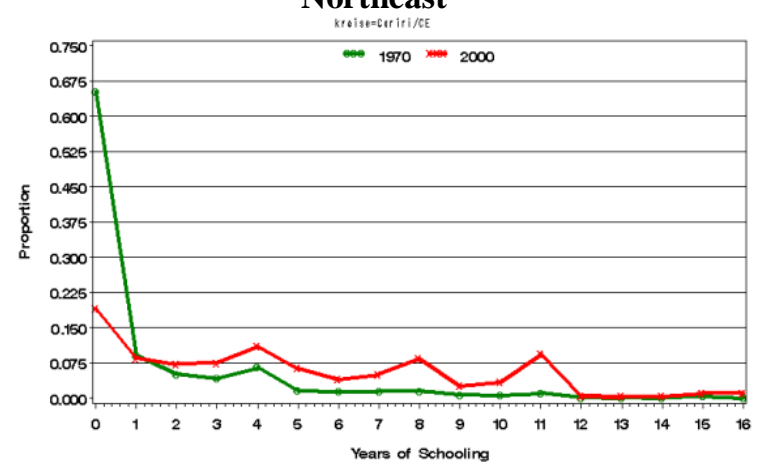

Mata Setentrional - Pernambuco

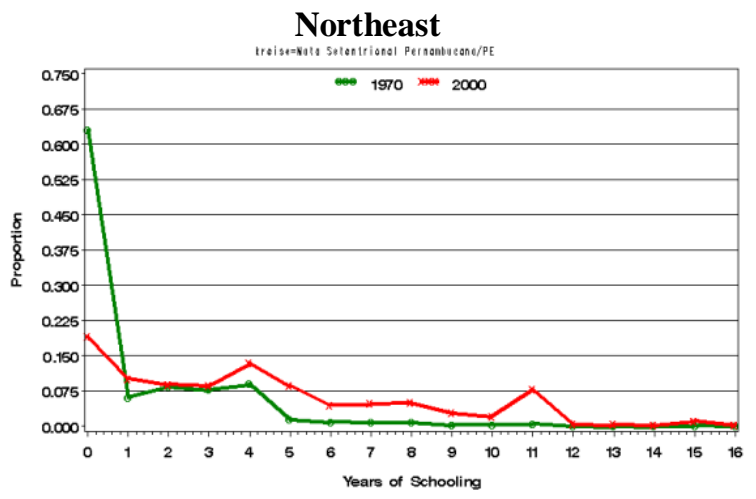

Campina Grande - Paraíba

Northeast

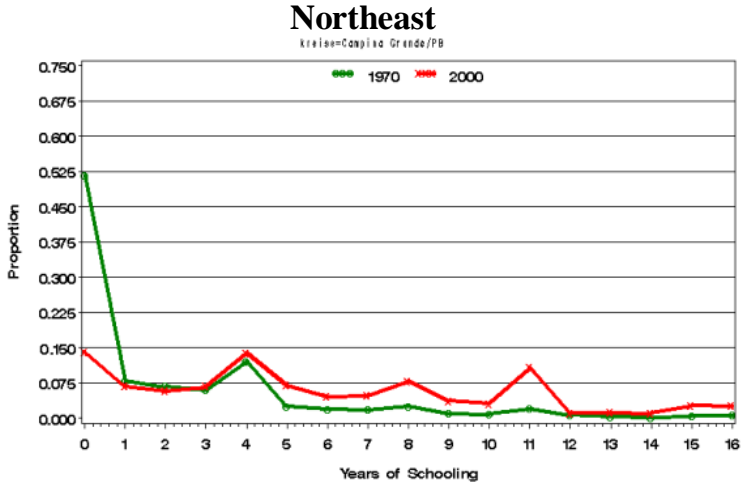

Ilhéus-Itabuna - Bahia

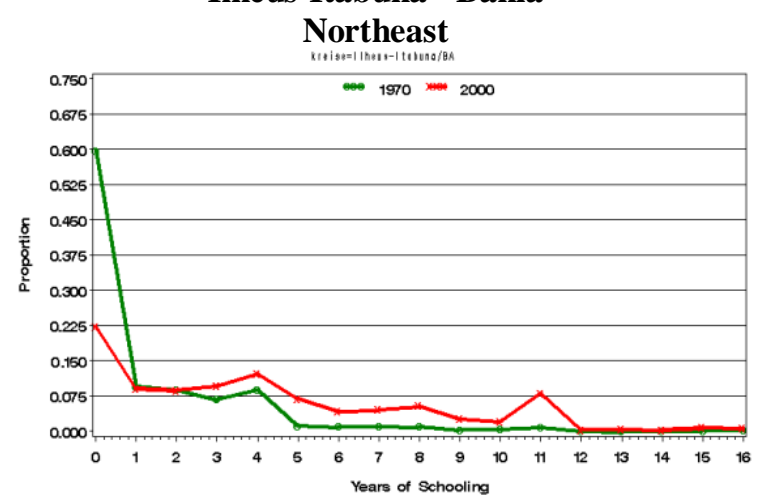

Source: 1970 and 2000 Brazilian Censuses. 
Figure 5.16. Changes in the Education Distribution in Selected Micro-regions (Southeast, South, Center-West), 1970 and 2000.

\section{Uberlândia - Minas Gerais}

Southeast

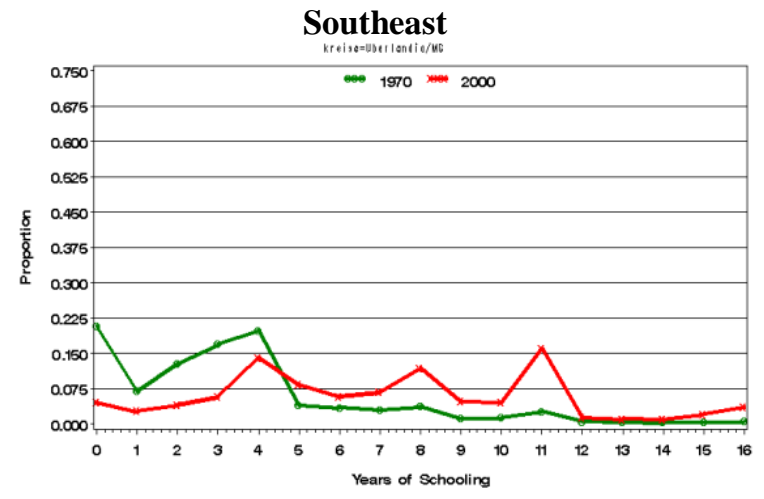

Volta Redonda - Rio de Janeiro

Southeast

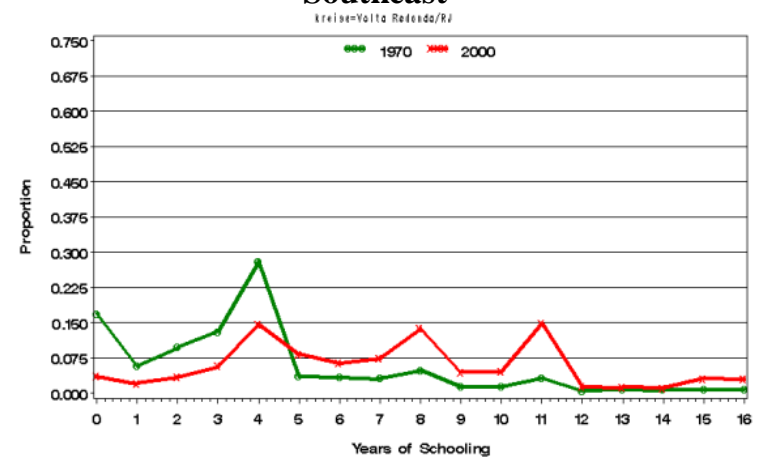

São José do Rio Preto - São Paulo Southeast

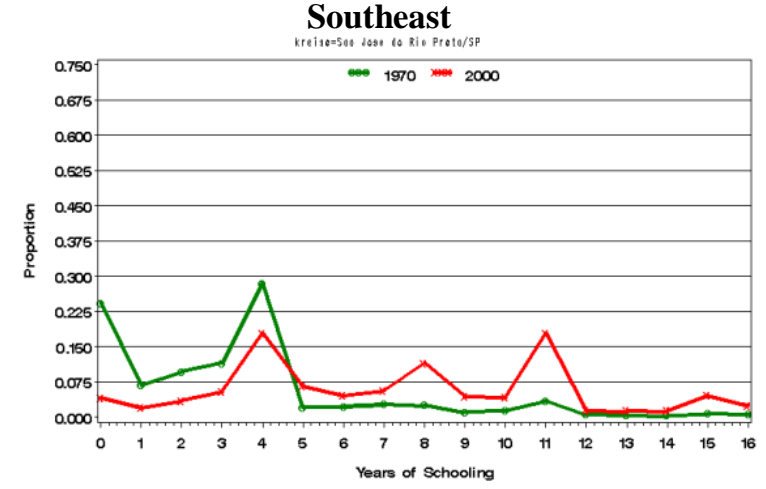

Source: 1970 and 2000 Brazilian Censuses.
Maringá - Paraná South

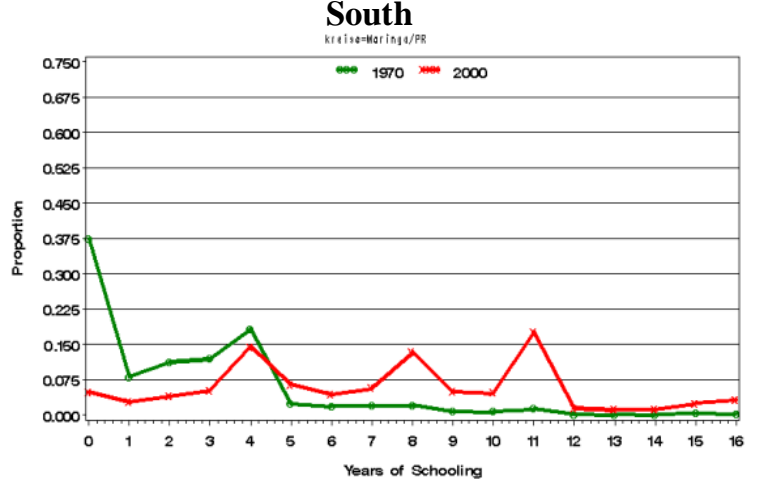

Porto Alegre - Rio Grande do Sul

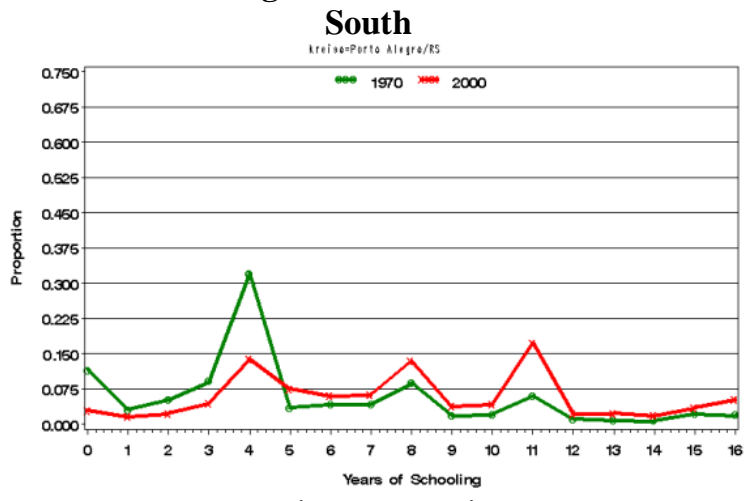

Anápolis - Goiás Center-West

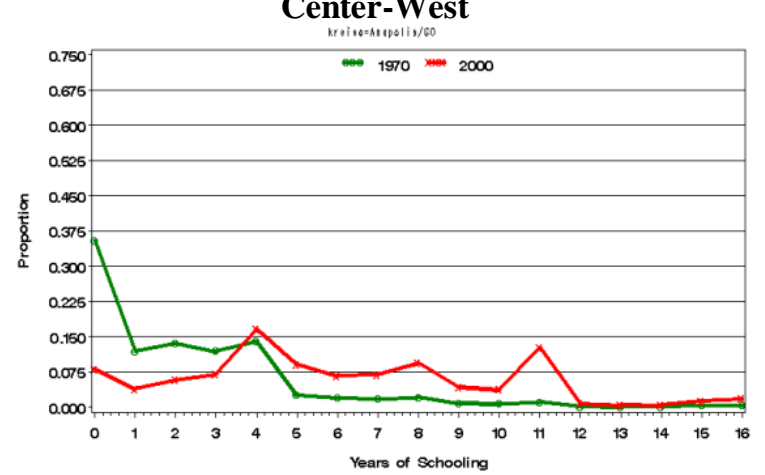




\section{ESTIMATING THE EFFECTS ON LABOR-MARKET OUTCOMES}

Since there are 502 micro-regions, 12 age-education groups and four Censuses, the maximum number of possible observations in the regressions is 24,096 . However, the requirement that there be at least 25 men with earnings in a micro-region in a cell, results in the exclusion of 4,369 observations, so that there are 19,727 observations throughout.

Table 5.1 shows the percent of male population by year and age-education groups in Brazil. In general, the numbers indicate that the proportion of people with zero to four years of schooling fell from 1960 to 2000 . For example, the proportion of people between 15-24 years of age, and 0-4 years of schooling dropped considerably from 30.8 percent in 1960 to 9.0 percent in 2000, a decrease of more than three times. Moreover, proportions of people with five to eight years of schooling, as well as those with at least nine years of schooling increased during the period. The highest increases in proportion of men with at least nine years of education were the ones for individuals with 15-24 years, from 1.1

percent in 1960 to 10.2 percent in 2000, and for those with $35-49$ years of age, from 0.9 to 8.5 , increases of more than nine times in forty years. 
Table 5.1. Percent of Male Population by Year and Age-Education Group, 1960-2000.

\begin{tabular}{|c|c|c|c|c|c|}
\hline $\begin{array}{c}\text { Age-education } \\
\text { Group }\end{array}$ & 1960 & 1970 & 1980 & 1991 & 2000 \\
\hline $\begin{array}{c}15-24 \text { years } \\
0-4 \text { years of schooling }\end{array}$ & 30.84 & 28.19 & 20.59 & 14.61 & 9.04 \\
\hline $\begin{array}{c}15-24 \text { years } \\
5-8 \text { years of schooling }\end{array}$ & 2.63 & 5.38 & 10.53 & 12.09 & 12.46 \\
\hline $\begin{array}{c}15-24 \text { years } \\
9+\text { years of schooling }\end{array}$ & 1.08 & 2.74 & 5.87 & 5.97 & 10.24 \\
\hline $\begin{array}{c}25-34 \text { years } \\
0-4 \text { years of schooling }\end{array}$ & 22.66 & 19.71 & 16.39 & 12.41 & 8.82 \\
\hline $\begin{array}{c}25-34 \text { years } \\
5-8 \text { years of schooling }\end{array}$ & 1.18 & 1.98 & 3.90 & 6.82 & 7.63 \\
\hline $\begin{array}{c}25-34 \text { years } \\
9+\text { years of schooling }\end{array}$ & 1.19 & 2.00 & 4.77 & 7.40 & 8.12 \\
\hline $\begin{array}{c}35-49 \text { years } \\
0-4 \text { years of schooling }\end{array}$ & 24.47 & 22.66 & 19.02 & 17.11 & 13.32 \\
\hline $\begin{array}{c}35-49 \text { years } \\
5-8 \text { years of schooling }\end{array}$ & 0.98 & 1.62 & 2.39 & 3.67 & 6.73 \\
\hline $\begin{array}{c}35-49 \text { years } \\
9+\text { years of schooling }\end{array}$ & 0.91 & 1.59 & 2.84 & 5.54 & 8.46 \\
\hline $\begin{array}{c}50-64 \text { years } \\
0-4 \text { years of schooling }\end{array}$ & 13.21 & 12.84 & 11.72 & 11.49 & 10.36 \\
\hline $\begin{array}{c}50-64 \text { years } \\
5-8 \text { years of schooling }\end{array}$ & 0.43 & 0.65 & 0.94 & 1.16 & 1.99 \\
\hline $\begin{array}{c}50-64 \text { years } \\
9+\text { years of schooling }\end{array}$ & 0.40 & 0.62 & 1.05 & 1.72 & 2.84 \\
\hline Total & $4,039,107^{+}$ & $25,760,600$ & $32,613,947$ & $43,434,534$ & $53,177,963$ \\
\hline
\end{tabular}

Table 5.2 shows estimates of a model that includes only indicators for ageeducation group. This model calculates changes in relative earnings in line with a Mincerian equation, which estimates the influence of years of schooling and experience on the earnings function. This is an extremely restrictive model, because it does not take into account the effects of changes in the size of each group on its earnings. The indicator 
variables for age-education groups show that within each age category earnings are higher for those people with more schooling. For instance, men ages 25-34 with zero to four years of schooling earn 1.46 times $[\exp (0.38)]$ what men ages $15-24$ with same education (the reference category) earn. Young adults (25-34) with at least nine years of schooling earn 5.05 times more $[\exp (1.62)]$. The estimates are thus consistent with what is known about age-earnings profiles and the impact of education on them. 
Table 5.2. Fixed-Effects Estimates Including Only Year and Age-Education Indicators, 1970-2000. Dependent Variable is $\log \left(\right.$ Monthly Earnings) ${ }^{+}$.

\begin{tabular}{|c|c|}
\hline Variables & Coefficients \\
\hline Constant & $5.15^{* * *}$ \\
\hline 1970 & - \\
\hline 1980 & $0.51 * * *$ \\
\hline 1991 & $0.08 * * *$ \\
\hline 2000 & $0.08 * * *$ \\
\hline \multicolumn{2}{|l|}{ Age-education Indicators } \\
\hline 15-24 years; $0-4$ years of schooling & - \\
\hline 15-24 years; 5-8 years of schooling & $0.31 * * *$ \\
\hline $15-24$ years; $9+$ years of schooling & $0.76^{* * * *}$ \\
\hline 25-34 years; 0-4 years of schooling & $0.38 * * *$ \\
\hline $25-34$ years; $5-8$ years of schooling & $0.99 * * *$ \\
\hline 25-34 years; 9+ years of schooling & $1.62 * * *$ \\
\hline 35-49 years; $0-4$ years of schooling & $0.61 * * *$ \\
\hline 35-49 years; 5-8 years of schooling & $1.40 * * *$ \\
\hline 35-49 years; $9+$ years of schooling & $2.11 * * *$ \\
\hline 50-64 years; 0-4 years of schooling & $0.63 * * *$ \\
\hline 50-64 years; 5-8 years of schooling & $1.58 * * *$ \\
\hline 50-64 years; $9+$ years of schooling & $2.29 * * *$ \\
\hline $\mathrm{N}$ observations & 19,727 \\
\hline $\mathrm{N}$ groups & 502 \\
\hline Rho: Fraction of variance due to the $v_{\mathrm{i}}$ & 0.66 \\
\hline $\mathrm{F}(14 ; 19,211):$ All coefficients $=0$ & $12,941.99 * * *$ \\
\hline $\mathrm{F}(501 ; 19,211):$ Area fixed effects $=0$ & $65.13 * * *$ \\
\hline
\end{tabular}

Table 5.3 presents estimates of Equation (1). The age-education indicators follow the same pattern of Table 5.2. The improvement from the last results is the inclusion of coefficients that take into account the effects of changes in the size of age-education groups on their earnings. The estimated coefficients of the proportions of men in each ageeducation group (the $\beta_{1}$ ) generally suggest greater negative impacts as the amount of education embodied in a worker increases. In order to interpret these coefficients, it is 
necessary to calculate elasticities, because the proportions of men vary across ageeducation groups over time (Table 5.1). These elasticities are presented in the final columns of Table 5.3. The results show that the elasticities of factor price are more negative among age-education groups with more education (five to eight years of schooling, and at least nine years of schooling). Moreover, the negative impacts increase over time among the more educated groups, while the elasticities for groups with the lowest educational attainment show decreases over time in the negative impact on earnings.

As observed in Table 5.3, an increase of ten percent in the number of people with five to eight years of schooling and between 15 and 24 years of age reduces their earnings by 1.8 percent (-0.179) in 1970 and 4.1 percent in 2000. Among young adults (25-34) in the same education group, the impact of the same shock also increases over time, from a reduction of 1.2 percent in 1970 to 4.6 percent in 2000. The same happens for adults (3549 ) and older adults (50-64) with five to eight years of schooling. The elasticities in the highest education groups also demonstrate significant negative impacts on earnings. Older adults (50-64) with at least nine years of schooling, however, and even adults (35-49) in this education group, see smaller negative impacts on earnings. 
Table 5.3. Fixed-Effects Estimates of Equation (1), 1970-2000. Dependent Variable is $\log$ (Monthly Earnings) ${ }^{+}$.

\begin{tabular}{|c|c|c|c|c|c|}
\hline Variables & Coefficients & & & & \\
\hline Constant & $5.11 * * *$ & & & & \\
\hline 1970 & - & & & & \\
\hline 1980 & $0.54 * * *$ & & & & \\
\hline 1991 & $0.15^{* * *}$ & & & & \\
\hline 2000 & $0.20 * * *$ & & & & \\
\hline \multicolumn{6}{|l|}{ Age-education Indicators } \\
\hline 15-24 years; $0-4$ years of schooling & - & & & & \\
\hline $15-24$ years; 5-8 years of schooling & $0.59 * * *$ & & & & \\
\hline $15-24$ years; $9+$ years of schooling & $0.97 * * *$ & & & & \\
\hline $25-34$ years; $0-4$ years of schooling & $0.42 * * *$ & & & & \\
\hline $25-34$ years; 5-8 years of schooling & $1.22 * * *$ & & & & \\
\hline $25-34$ years; $9+$ years of schooling & $1.80 * * *$ & & & & \\
\hline $35-49$ years; $0-4$ years of schooling & $0.83 * * *$ & & & & \\
\hline $35-49$ years; 5-8 years of schooling & $1.58 * * *$ & & & & \\
\hline $35-49$ years; $9+$ years of schooling & $2.17 * * *$ & & & & \\
\hline 50-64 years; 0-4 years of schooling & $0.83 * * *$ & & & & \\
\hline 50-64 years; 5-8 years of schooling & $1.70 * * *$ & & & & \\
\hline $50-64$ years; $9+$ years of schooling & $2.24 * * *$ & $\begin{array}{r}\text { (ba } \\
\text { di }\end{array}$ & $\begin{array}{l}\text { d on the } \\
\text { ribution }\end{array}$ & $\begin{array}{l}\text { age-edu } \\
\text { of Table }\end{array}$ & $\begin{array}{l}\text { ation } \\
\text { 5.1) }\end{array}$ \\
\hline Proportions of Men in Age-education Groups & & 1970 & 1980 & 1991 & 2000 \\
\hline Ages $15-24$ years; $0-4$ years of schooling & -0.08 & -0.023 & -0.016 & -0.012 & -0.007 \\
\hline Ages $15-24$ years; $5-8$ years of schooling & $-3.32 * * *$ & -0.179 & -0.350 & -0.401 & -0.414 \\
\hline Ages $15-24$ years; $9+$ years of schooling & $-4.81 * * *$ & -0.132 & -0.282 & -0.287 & -0.492 \\
\hline Ages $25-34$ years; $0-4$ years of schooling & $-0.37 * *$ & -0.073 & -0.061 & -0.046 & -0.033 \\
\hline Ages $25-34$ years; $5-8$ years of schooling & $-6.00 * * *$ & -0.119 & -0.234 & -0.409 & -0.458 \\
\hline Ages $25-34$ years; $9+$ years of schooling & $-5.37 * * *$ & -0.107 & -0.256 & -0.398 & -0.436 \\
\hline Ages 35-49 years; $0-4$ years of schooling & $-1.19 * * *$ & -0.270 & -0.226 & -0.204 & -0.159 \\
\hline Ages $35-49$ years; $5-8$ years of schooling & $-7.23 * * *$ & -0.117 & -0.173 & -0.265 & -0.486 \\
\hline Ages $35-49$ years; $9+$ years of schooling & $-3.08 * * *$ & -0.049 & -0.087 & -0.171 & -0.260 \\
\hline Ages $50-64$ years; $0-4$ years of schooling & $-1.66 * * *$ & -0.213 & -0.195 & -0.191 & -0.172 \\
\hline Ages $50-64$ years; $5-8$ years of schooling & $-16.12 * * *$ & -0.105 & -0.151 & -0.187 & -0.321 \\
\hline Ages $50-64$ years; $9+$ years of schooling & -0.25 & -0.002 & -0.003 & -0.004 & -0.007 \\
\hline $\mathrm{N}$ observations & 19,727 & & & & \\
\hline $\mathrm{N}$ groups & 502 & & & & \\
\hline Rho: Fraction of variance due to the $v_{i}$ & 0.73 & & & & \\
\hline F $(26 ; 19,199):$ All coefficients $=0$ & $8,506.08 * * *$ & & & & \\
\hline $\mathrm{F}(501 ; 19,199):$ Area fixed effects $=0$ & $57.02 * * *$ & & & & \\
\hline
\end{tabular}


Overall, the results show that an identical percentage-point increase in the proportion of people with more schooling generates larger negative impacts on earnings. This result is consistent with the substantial evidence from industrialized economies that own-price elasticities of labor demand fall with educational attainment and with the sparser evidence for those economies that elasticities of factor price rise with education (Hamermesh 1993, chapter 3). Moreover, that the factor-price elasticities have been increasing over time, except among the least-educated group, suggests either that a given amount of education implies that more skill is embodied in a group of workers now than in 1970, or that the Brazilian labor market has become more rigid.

The estimates permit the comparison of the predicted mean monthly real earnings among different age-education groups over the range of the actual proportions of people in these groups in Brazilian micro-regions. Figure 5.17 exhibits predicted earnings for young men (25-34) with at least nine years of schooling, and for men (35-49) with zero to four years of schooling. Most importantly, these figures illustrate that earnings are lower among men who live in micro-regions with higher proportions of male workers in their own ageeducation group. The negative impact on earnings of a higher proportion of people in one's own group is greater for young adults with 9+ years of education, as can be discerned by the steeper curves for them, compared to those for adults with less education.

Moreover, as was expressed in Figures 5.6 and 5.7, proportions of males ages 2534 with at least nine years of schooling are increasing over time, while males ages 35-49 with zero to four years of schooling show decreasing proportions from 1970 to 2000 . As a result of the changing age-education distribution, as well as the greater negative impact of group size on earnings for better educated workers, the difference in real earnings between these two groups in Figure 5.17 is decreasing over time. 
Figure 5.17. Predicted Earnings ${ }^{+}$from Equation (1) by Proportion of Men in AgeEducation Groups for 502 Micro-regions, Men 25-34 with 9+ Years of Schooling, and Men 35-49 with 0-4 Years of Schooling, 1970-2000.
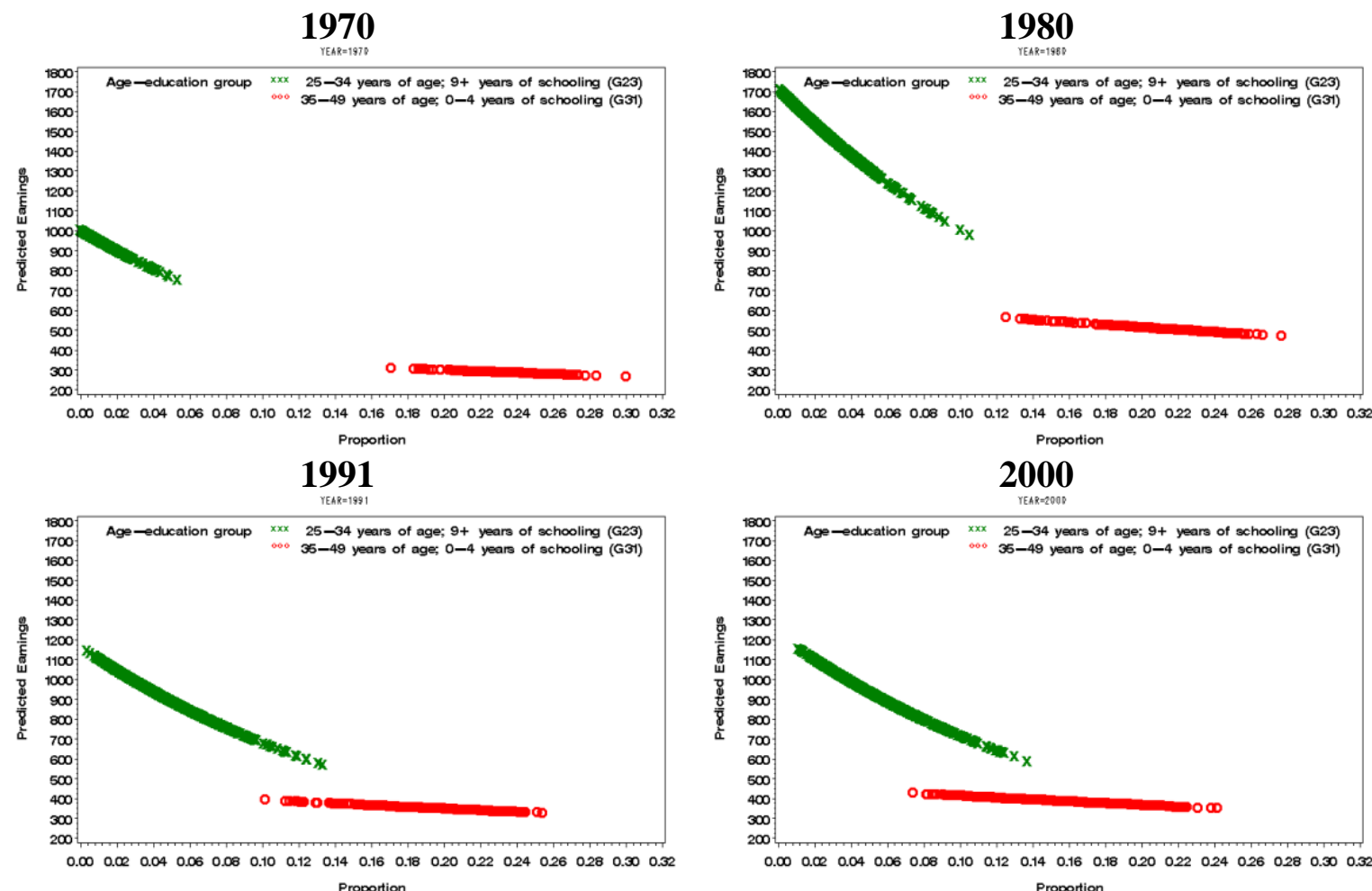

+ Nominal income was converted to base 1 in January 2002, taking into account changes in currency, and inflation. Source: 1970-2000 Brazilian Censuses.

Table 5.4 presents estimates of Equation (1'), which allows own-quantity effects to vary over time directly. Interactions with year indicators illustrate that the negative impacts of the changing distributions of workers across micro-regions have been decreasing. This is observed mainly for 1991 and 2000 for the least educated and the oldest group of workers. Among them the positive coefficients on the interaction terms essentially offset the negative coefficients on the main effect terms. Between the other groups, particularly the highest-educated and prime-age workers, the impacts of increasing shares of the work force remain negative throughout. 
Table 5.4. Fixed-Effects Estimates of Equation (1'), 1970-2000. Dependent Variable is $\log$ (Monthly Earnings) ${ }^{+}$.

\begin{tabular}{|c|c|c|c|c|}
\hline Variables & \multicolumn{4}{|c|}{ Coefficients } \\
\hline Constant & \multicolumn{4}{|l|}{$5.30 * * *$} \\
\hline 1970 & - & & & \\
\hline 1980 & $0.45^{* * *}$ & & & \\
\hline 1991 & $-0.06 * * *$ & & & \\
\hline 2000 & $-0.05 * * *$ & & & \\
\hline \multicolumn{5}{|l|}{ Age-education Indicators } \\
\hline 15-24 years; $0-4$ years of schooling & - & & & \\
\hline $15-24$ years; $5-8$ years of schooling & $0.52 * * *$ & & & \\
\hline $15-24$ years; $9+$ years of schooling & $0.90 * * *$ & & & \\
\hline $25-34$ years; $0-4$ years of schooling & $0.44 * * *$ & & & \\
\hline $25-34$ years; $5-8$ years of schooling & $1.12 * * *$ & & & \\
\hline $25-34$ years; $9+$ years of schooling & $1.68 * * *$ & & & \\
\hline $35-49$ years; $0-4$ years of schooling & $0.75 * * *$ & & & \\
\hline $35-49$ years; $5-8$ years of schooling & $1.51 * * *$ & & & \\
\hline $35-49$ years; $9+$ years of schooling & $2.11 * * *$ & & & \\
\hline 50-64 years; $0-4$ years of schooling & $0.77 * * *$ & & & \\
\hline $50-64$ years; 5-8 years of schooling & $1.61 * * *$ & & & \\
\hline $50-64$ years; $9+$ years of schooling & $2.23 * * *$ & & & \\
\hline & & \multicolumn{3}{|c|}{ Interactions with Year } \\
\hline \multicolumn{2}{|c|}{ Proportions of Men in Age-education Groups } & 1980 & 1991 & 2000 \\
\hline Ages $15-24$ years; $0-4$ years of schooling & $-0.77 * * *$ & $0.34 * * *$ & $0.90 * * *$ & $1.32 * * *$ \\
\hline Ages $15-24$ years; $5-8$ years of schooling & $-5.08 * * *$ & $0.71 *$ & $3.20 * * *$ & $3.06 * * *$ \\
\hline Ages $15-24$ years; $9+$ years of schooling & $-4.82 * * *$ & $-1.18^{*}$ & $2.07 * * *$ & $1.68 * *$ \\
\hline Ages $25-34$ years; $0-4$ years of schooling & $-1.60 * * *$ & $0.98 * * *$ & $1.31 * * *$ & $1.63 * * *$ \\
\hline Ages $25-34$ years; 5-8 years of schooling & $-6.81 * * *$ & 0.20 & $2.87 * *$ & $3.20 * * *$ \\
\hline Ages $25-34$ years; $9+$ years of schooling & -1.43 & $-2.39 * *$ & -0.93 & $-1.94 *$ \\
\hline Ages 35-49 years; $0-4$ years of schooling & $-1.98 * * *$ & $1.00 * * *$ & $1.56 * * *$ & $1.66 * * *$ \\
\hline Ages $35-49$ years; $5-8$ years of schooling & $-8.67 * * *$ & 0.74 & $2.72 *$ & $3.92 * * *$ \\
\hline Ages $35-49$ years; $9+$ years of schooling & $-4.63 * * *$ & -1.04 & $3.67 * *$ & $3.35^{* *}$ \\
\hline Ages 50-64 years; 0-4 years of schooling & $-3.44 * * *$ & $1.68 * * *$ & $2.67 * * *$ & $3.55 * * *$ \\
\hline Ages $50-64$ years; $5-8$ years of schooling & $-8.66^{* *}$ & -2.38 & -1.30 & 1.48 \\
\hline Ages 50-64 years; $9+$ years of schooling & $-15.98 * * *$ & 1.58 & $17.85^{* * *}$ & $19.39 * * *$ \\
\hline N observations & 19,727 & & & \\
\hline $\mathrm{N}$ groups & 502 & & & \\
\hline Rho: Fraction of variance due to the $v_{i}$ & 0.74 & & & \\
\hline $\mathrm{F}(62 ; 19,163):$ All coefficients $=0$ & $3,957.16 * * *$ & & & \\
\hline $\mathrm{F}(501 ; 19,163):$ Area fixed effects $=0$ & $53.20 * * *$ & & & \\
\hline
\end{tabular}


In one respect, results of Equation (1') in Table 5.4 show that interaction terms only slightly offset the main negative effect for least educated workers. For men with zero to four years of schooling, the sum of the interaction term in 2000 to the main effect equals $0.55(-0.77+1.32)$ for ages $15-24 ; 0.03$ for ages $25-34 ;-0.32$ for ages $35-49$; and 0.11 for ages 50-64. The only interaction term that generates a great positive impact on earnings is the one for the oldest workers with at least nine years of education, creating a final impact of $3.41(-15.98+19.39)$ in 2000 . In other words, the decrease in proportion of workers with low levels of education does not have a large, beneficial impact on their earnings.

In another respect, these results illustrate that the negative effect of increasing shares on earnings for higher educated workers is still evident in 2000. Adding the main effect to the interaction term in 2000, workers with five to eight years of schooling present a negative effect of $-2.02(-5.08+3.06)$ for ages $15-24 ;-3.61$ for ages $25-34 ;-4.75$ for ages 35-49; and -7.18 for ages 50-64. These large negative effects are also observed by the highest-educated workers, excluding the oldest group, such as mentioned above.

To better understand the coefficients in Table 5.4, elasticities of factor price were estimated, taking into account the main own-share coefficient, the year interactions, and the national age-education distribution. These elasticities are shown in Table 5.5 and, such as the elasticities in Table 5.3, they imply that negative effects of the own-share proportions are more negative among groups with more education. Among the lowest educated groups, the elasticities present values even closer to zero over time than elasticities of Table 5.3. Results in Table 5.5 suggest that the proportions of least-skilled groups are becoming so small in the population that the supply side pressure on earnings no longer matters. 
Table 5.5. Elasticities for Estimates of Equation (1'), Based on the National AgeEducation Distribution of Table 5.1, 1970-2000. Dependent Variable is $\log (\text { Monthly Earnings })^{+}$.

\begin{tabular}{l|cccc} 
Proportions of Men in Age-education Groups & \multicolumn{4}{|c}{ Elasticity } \\
& $\mathbf{1 9 7 0}$ & $\mathbf{1 9 8 0}$ & $\mathbf{1 9 9 1}$ & $\mathbf{2 0 0 0}$ \\
\hline Ages 15-24 years; 0-4 years of schooling & -0.217 & -0.089 & 0.019 & 0.050 \\
Ages 15-24 years; 5-8 years of schooling & -0.273 & -0.460 & -0.227 & -0.252 \\
Ages 15-24 years; 9+ years of schooling & -0.132 & -0.352 & -0.164 & -0.321 \\
\hline Ages 25-34 years; 0-4 years of schooling & -0.315 & -0.102 & -0.077 & 0.003 \\
Ages 25-34 years; 5-8 years of schooling & -0.135 & -0.258 & -0.451 & -0.275 \\
Ages 25-34 years; 9+ years of schooling & -0.029 & -0.182 & -0.283 & -0.274 \\
\hline Ages 35-49 years; 0-4 years of schooling & -0.449 & -0.186 & -0.168 & -0.043 \\
Ages 35-49 years; 5-8 years of schooling & -0.141 & -0.189 & -0.291 & -0.320 \\
Ages 35-49 years; 9+ years of schooling & -0.074 & -0.161 & -0.314 & -0.108 \\
\hline Ages 50-64 years; 0-4 years of schooling & -0.442 & -0.206 & -0.202 & 0.011 \\
Ages 50-64 years; 5-8 years of schooling & -0.056 & -0.104 & -0.128 & -0.143 \\
Ages 50-64 years; 9+ years of schooling & -0.100 & -0.151 & -0.247 & 0.097 \\
\hline
\end{tabular}

${ }^{+}$Nominal income was converted to base 1 in January 2002, taking into account changes in currency and inflation. Source: 1970-2000 Brazilian Censuses.

Different from the findings in estimates of Table 5.3, elasticities in Table 5.5 suggest that the negative impacts among the more educated groups do not have a smooth increasing trend over time. More specifically, negative impacts increase over time in those groups, but with eventual decreases from 1980 to 1991, and from 1991 to 2000.

These findings are in line with previous analysis that even lower educated groups might have been competing with other groups, as shown by small positive impacts on earnings, even with year interaction. Moreover, this might be evidence that the labor market is now demanding higher levels of skill and education from workers, generating greater negative impacts of shares on earnings for groups with higher levels of education.

Another way to view the implications of the estimates of the own-effects model (as well as own-effects interacted with year indicators) is to consider how the changing national distribution of males by age-education group from 1970 to 2000 affects predicted earnings within the group (Figures 5.18 and 5.19). In order to accomplish this exercise, 
national proportions of males by age-education group and Census year (Table 5.1) were used to forecast earnings, applying the coefficients from Tables 5.3 and 5.4. The figures show that groups with declining proportions experience gains in earnings, and vice-versa for groups whose representation is growing.

Figure 5.18. Ratios of Predicted Earnings from Equation (1) to Predicted Earnings from Table 5.2, using the National Age-Education Distribution, 1970-2000.

Men 15-24

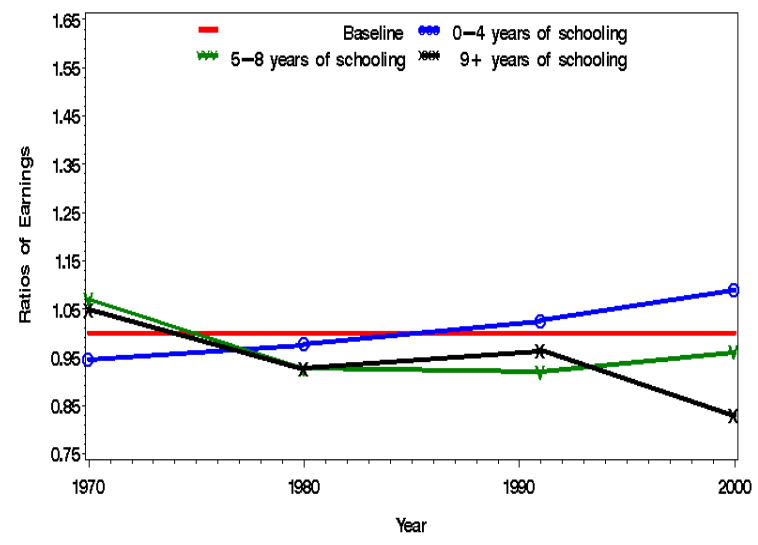

Men 35-49

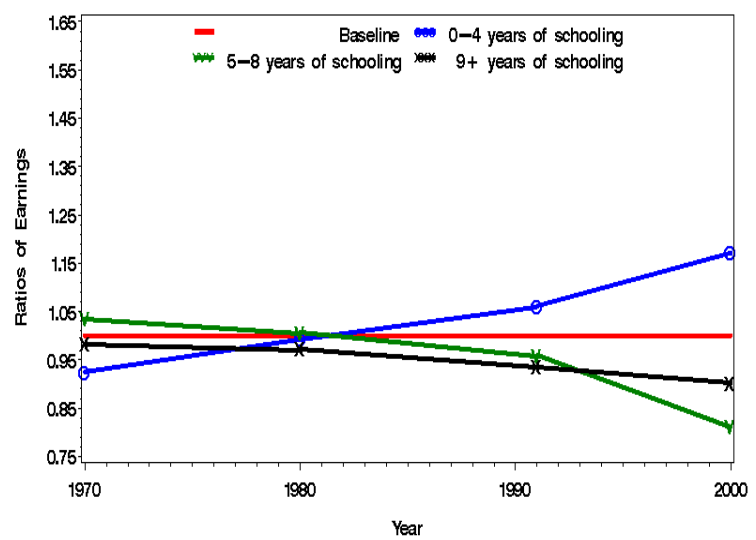

Men 25-34
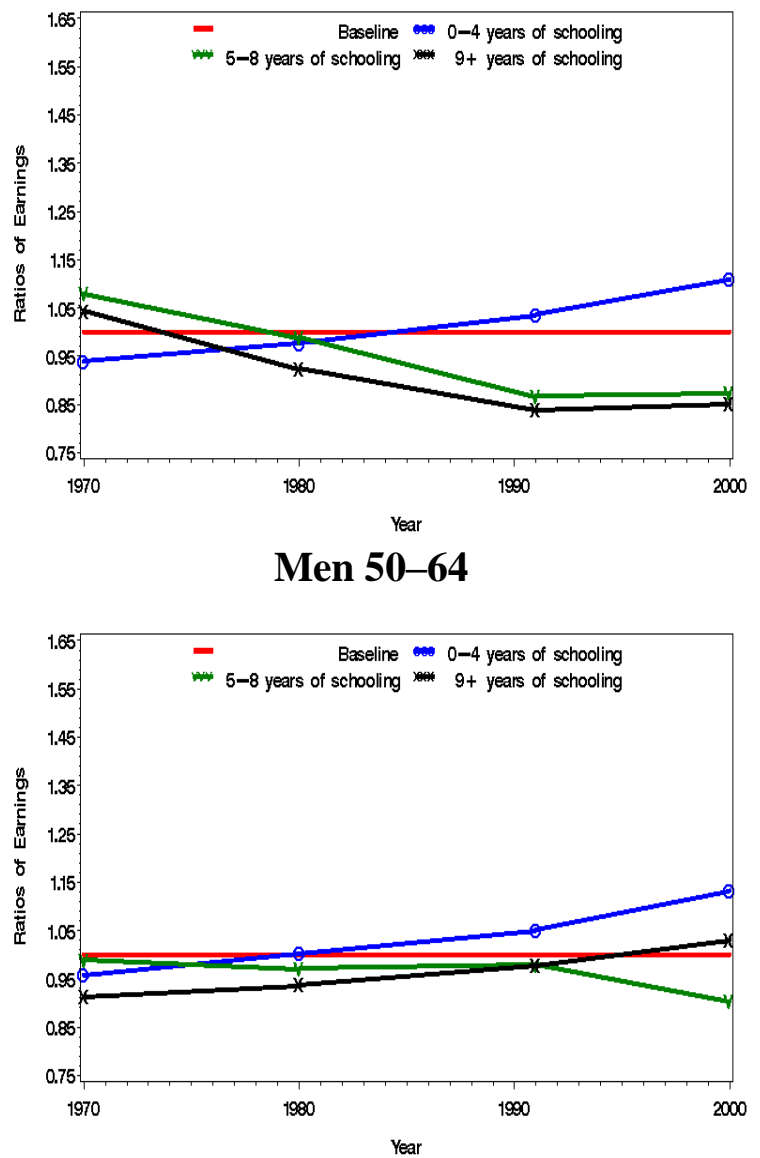

Note: The scale in the vertical axis is the same in Figures 5.18, 5.19, 7.1, 7.2, 7.3, and 7.4 for comparison purposes. Source: 1970-2000 Brazilian Censuses. 
Figure 5.19. Ratios of Predicted Earnings from Equation (1') to Predicted Earnings from Table 5.2, using the National Age-Education Distribution, 1970-2000.

Men 15-24

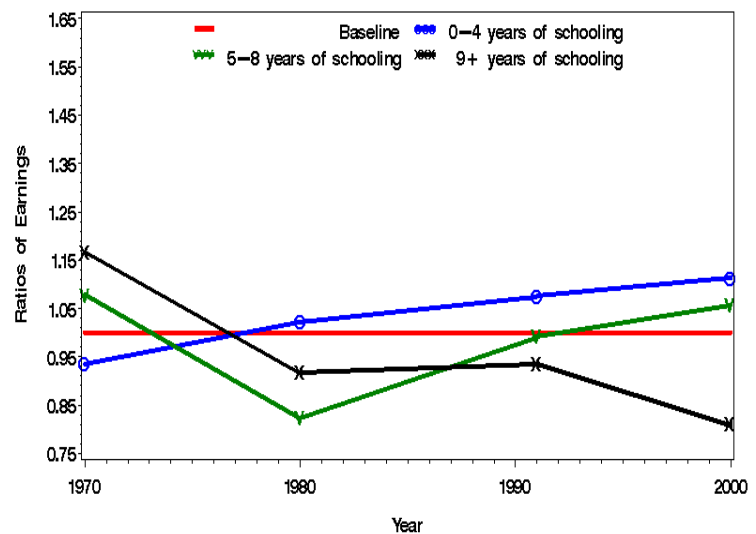

Men 35-49

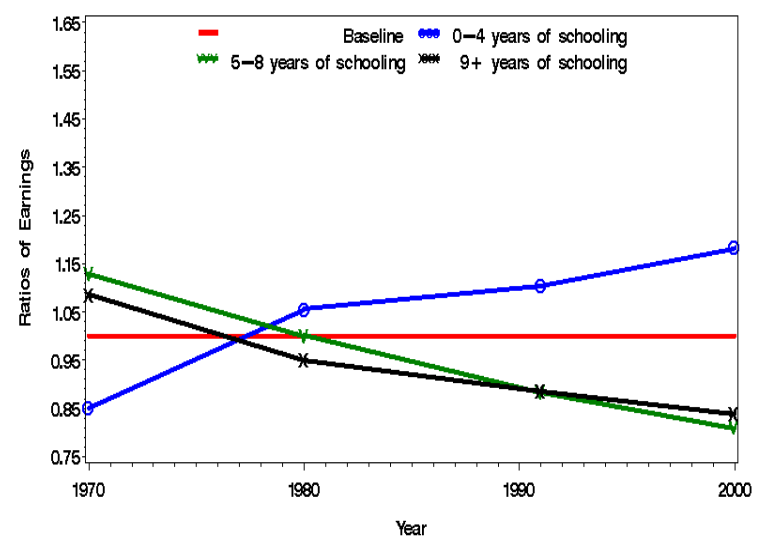

Men 25-34

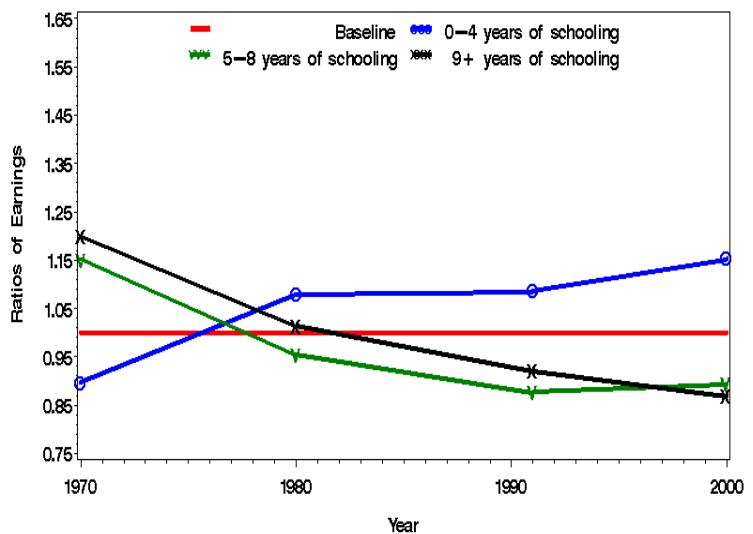

Men 50-64

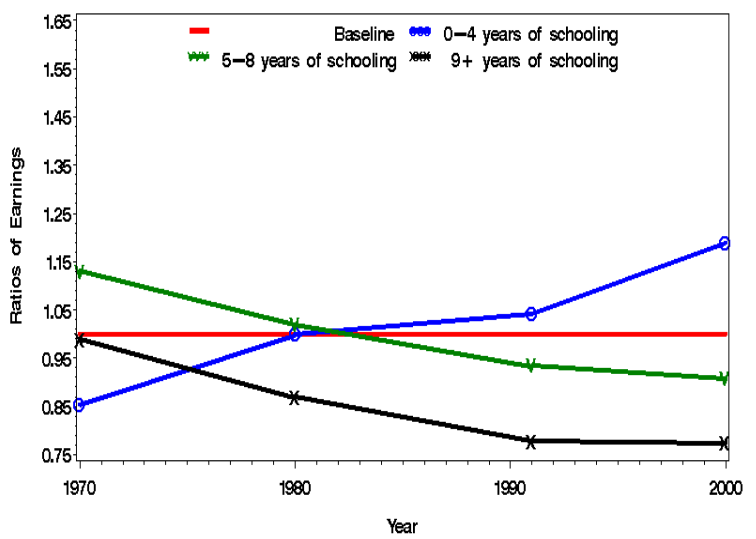

Note: The scale in the vertical axis is the same in Figures 5.18, 5.19, 7.1, 7.2, 7.3, and 7.4 for comparison purposes. Source: 1970-2000 Brazilian Censuses.

The graphs plot the ratio of predicted earnings from the own-effects model (Table 5.3, Figure 5.18), and from the own-effects model interacted with year (Table 5.4, Figure 5.19), to predicted earnings from the model that includes only indicators for age-education groups and years (Table 5.2). Figures 5.18 and 5.19 illustrate the curves for all three education groups within each age group. The horizontal line shows baseline predicted values from the model that includes only age-education and year indicators, i.e., the model 
that excludes the proportions in each age-education group (Table 5.2) is set to be equal to one. Comparing the curves in Figures 5.18 and 5.19 to the baseline predictions, one can see that the low-education group (zero to four years of schooling) has predicted earnings from the own-effects models (and own-effects interacted with year) that are increasing over time. These changes make it absolutely clear that it is insufficient to look simply at changes in relative earnings; rather, the effects of changes in the size of each group on its earnings help make the prediction of earnings changes more accurate.

A substantial difference in trends between Figures 5.18 and 5.19 is for the oldest age group with at least nine years of schooling. In Figure 5.18, this group experienced gains in earnings even with an increase on its proportion from 1.7 percent in 1991 to 2.8 percent in 2000 (Table 5.1). This happened because the negative impact of the own-share $(-0.25$ in Table 5.3) is too small to offset the direct impact of age and education (2.24 in Table 5.3) on earnings. In Figure 5.19, the negative impact of the own-share (-15.98 in Table 5.4) has to be added to the year interactions (1.58 for 1980 ; 17.85 for 1991 ; and 19.39 for 2000 in Table 5.4). Even with greater negative impacts in 1970 and 1980 compared to 1991 and 2000 , the increase in the proportion of this group over time ( 0.6 percent in $1970 ; 1.1$ percent in 1980; 1.7 percent in 1991; and 2.8 percent in 2000 in Table 5.1) was strong enough to offset the direct impact of age and education (2.23 in Table 5.4) on earnings. These changes generated a downward curve between 1970 and 1991, and a constant trend from 1991 to 2000.

Moreover, the youngest group with five to eight years of schooling presented an increase in earnings from 1991 to 2000 in Figure 5.18, and from 1980 to 2000 in Figure 5.19, even with an increase from 10.5 percent in 1980 to 12.5 in 2000 (Table 5.1). This result shows that the small increase in the share of this young group during the period was insufficient in offsetting the direct gains on earnings provided by education. 
For each of the 12 selected micro-regions (the same as those examined in Figures 5.13, 5.14, 5.15 and 5.16), Figures 5.20 and 5.21 address the ratio between predicted mean earnings from the simple model (Equation (1)) that restricted own-quantity effects to not vary over time (Table 5.3), and the predicted earnings from the baseline regression that only includes the age-education-group and year indicators (Table 5.2). This figure is designed to show the differences in estimated earnings between a model that takes into account age and education structures (proportions of people by age-education groups) and a model of that considers only the direct impact of age and education on earnings. A second set of ratios in Figures 5.20 and 5.21 compares predicted earnings from the model that includes own-quantity effects that vary over time directly (Equation (1'), Table 5.4), and the baseline model that only incorporates the age-education-group and year indicators (Table 5.2). The dashed line indicates the ratio between observed and predicted earnings from the model that only includes age-education indicators; it demonstrates how well the predictions fit the data in the selected areas. The baseline consists of predicted values from the model that includes only age-education indicators (Table 5.2), and they equal to one for comparison reasons. Ratios presented for 1970 to 2000 in Figures 5.20 and 5.21 are for males ages 35-49 between five and eight years of schooling.

The curves in Figures 5.20 and 5.21 demonstrate that the slopes of predicted earnings from Equations (1) and (1') accord fairly well with the slopes actually found in the data, all in relation to predicted earnings based on a model without group-size effects. Note, however, that the curves are flatter in the Northeastern areas (Figure 5.20) than in the areas from the Southeast, South and Center-West (Figure 5.21), due to the greater shift in the proportions in this group found in the latter areas. The calculations presented in these figures show that the observed variations over time have patterns that are more similar to 
those in predicted earnings from the Equation ( $\left.1^{\prime}\right)$, than from the more restrictive model that excludes interaction with time (Equation (1)). 
Figure 5.20. Ratios of Observed Earnings, of Predicted Earnings from Equation (1), and of Predicted Earnings from Equation (1'), to Predicted Earnings from Table 5.2, Males Ages 35-49 with 5-8 Years of Education, 1970-2000, Selected Micro-regions (Northeast).
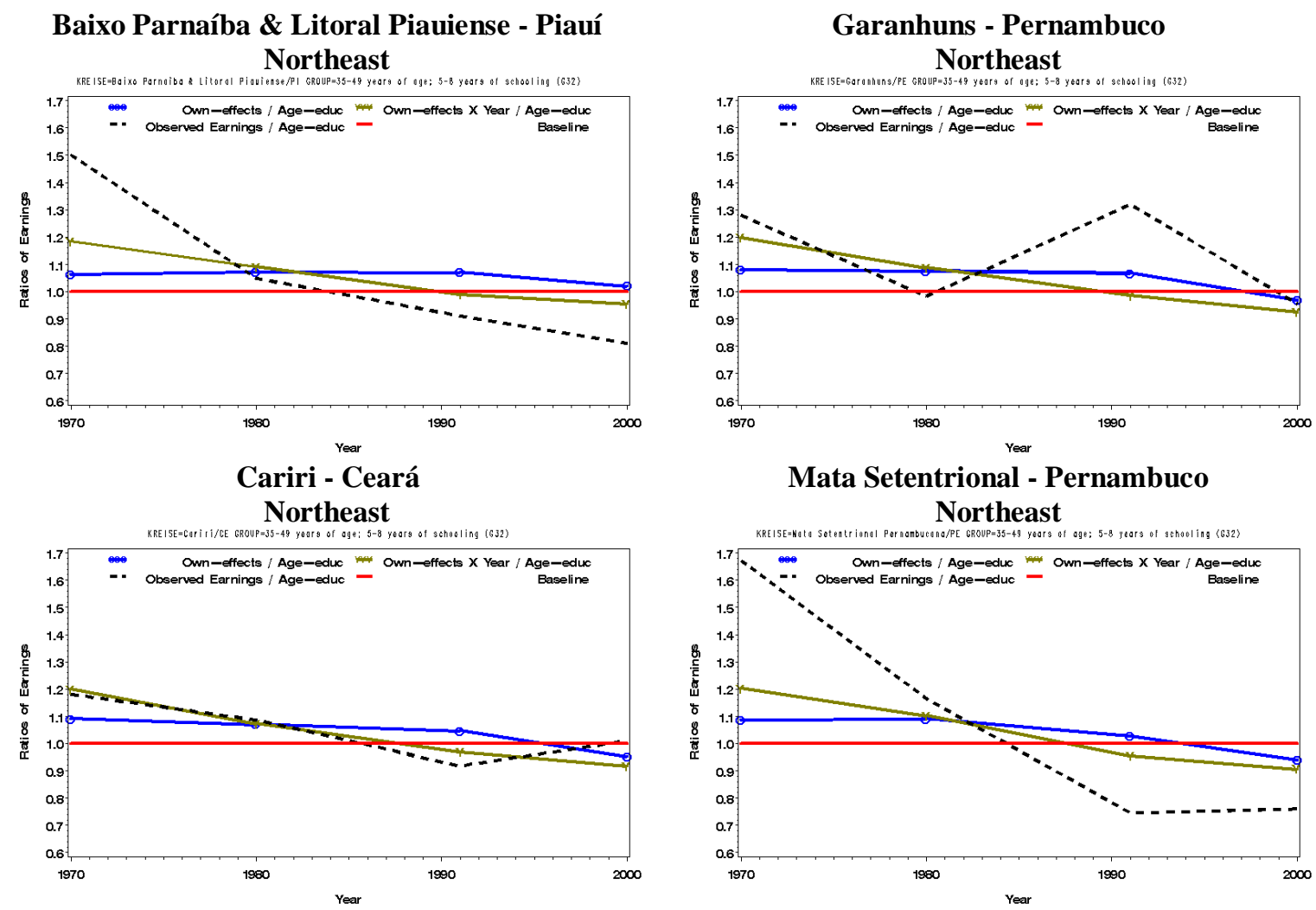

Campina Grande - Paraíba Northeast

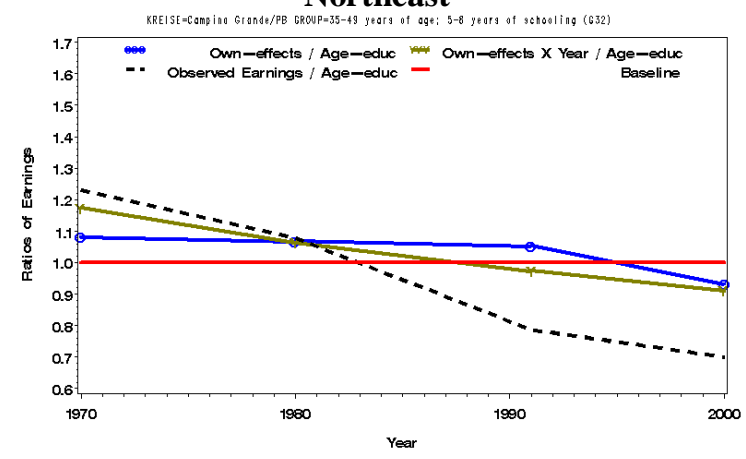

Mata Setentrional - Pernambuco Northeast

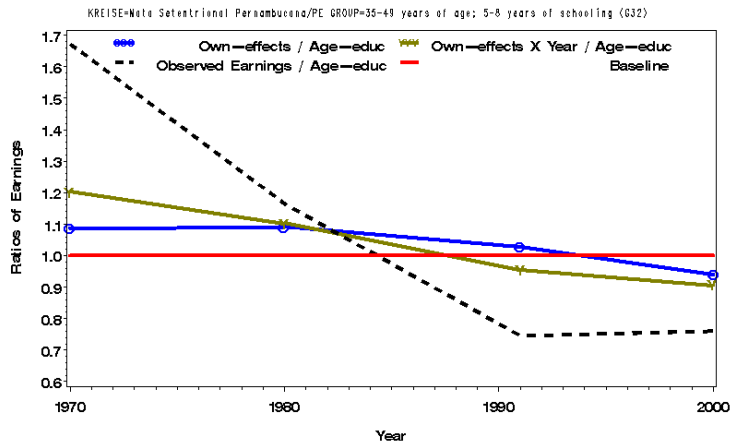

Ilhéus-Itabuna - Bahia

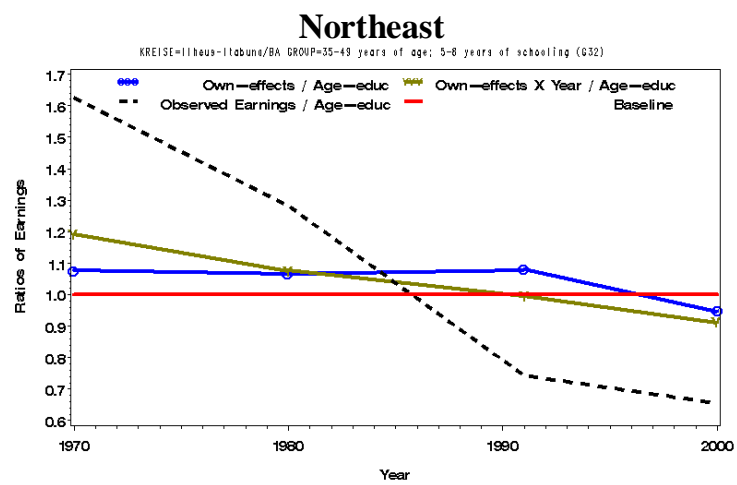

Source: 1970-2000 Brazilian Censuses. 
Figure 5.21. Ratios of Observed Earnings, of Predicted Earnings from Equation (1), and of Predicted Earnings from Equation (1'), to Predicted Earnings from Table 5.2, Males Ages 35-49 with 5-8 Years of Education, 1970-2000, Selected Micro-regions (Southeast, South, Center-West).
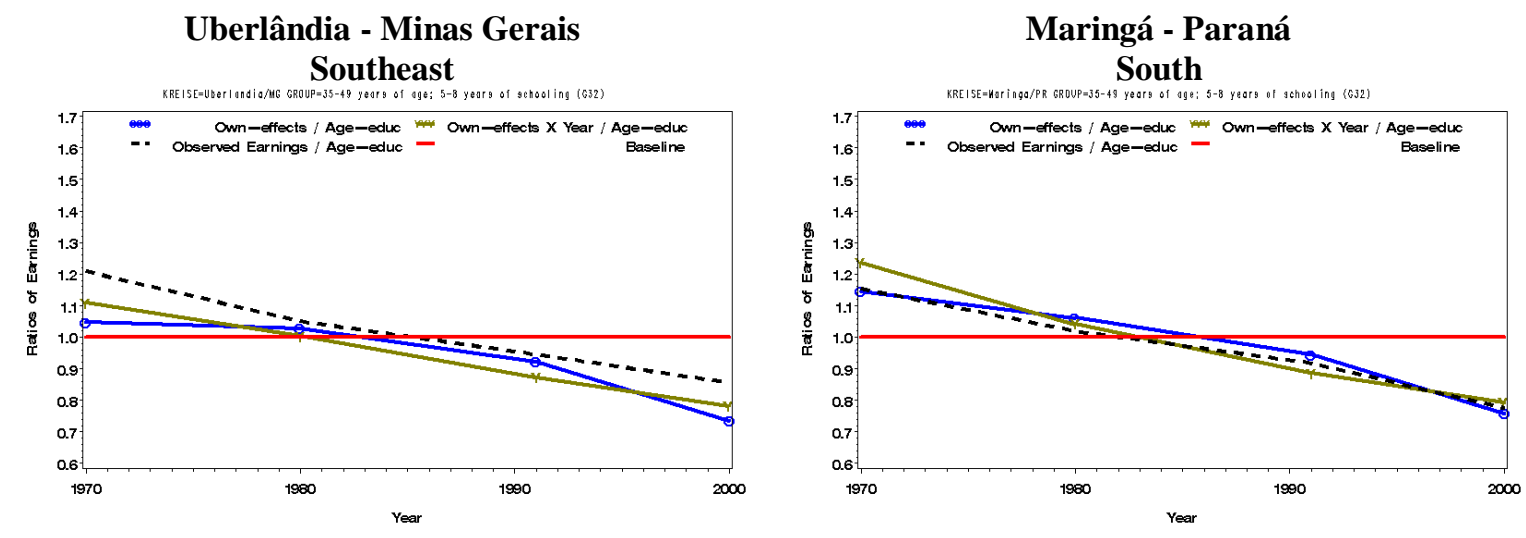

Volta Redonda - Rio de Janeiro Southeast

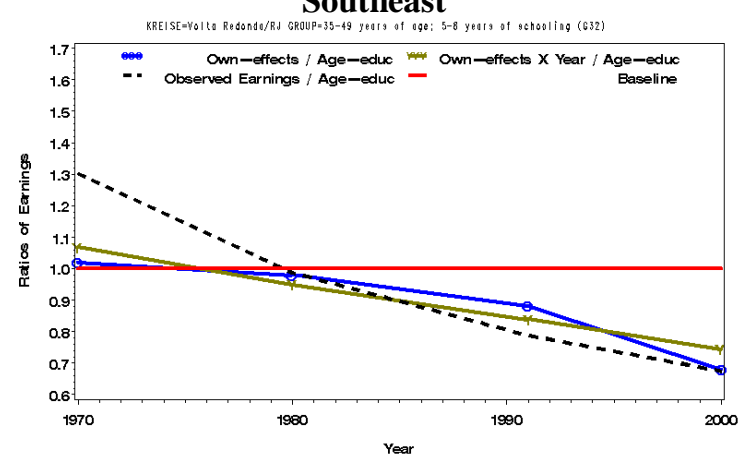

São José do Rio Preto - São Paulo Southeast
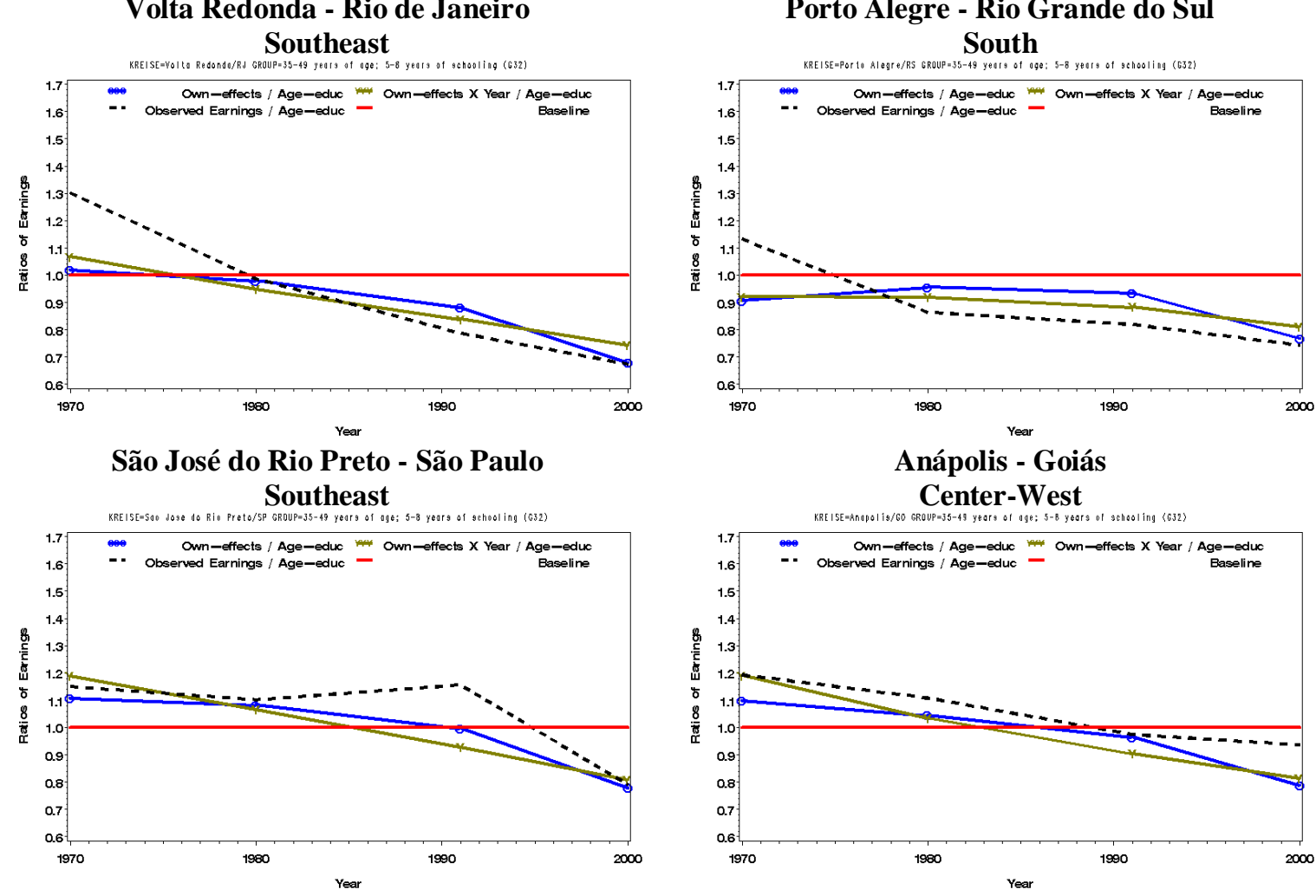

Anápolis - Goiás

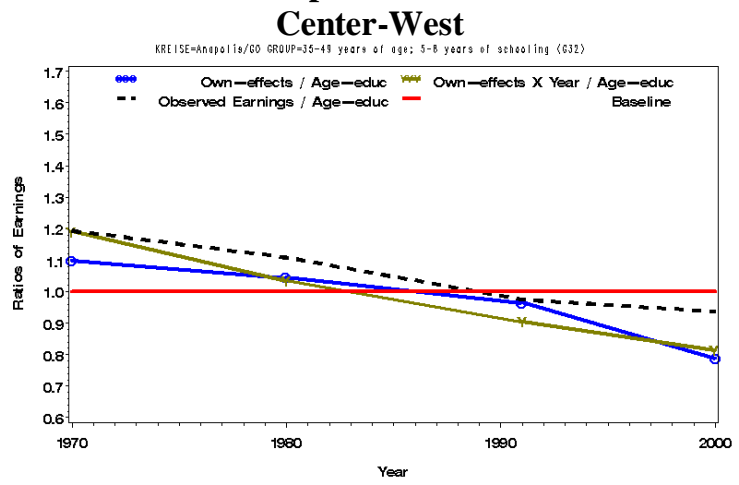

Source: 1970-2000 Brazilian Censuses. 
Table 5.6 presents estimates of Equation (2) that includes cross-quantity effects. The number of coefficients (147 in total) is daunting and makes it hard to interpret the results. In order to understand the estimates, Figures 5.22 and 5.23 can be analyzed by comparing estimates of Equations (1) and (2), such as it was done above for Equations (1) and (1').

More than illustrating the ratio between observed and predicted earnings from the model that only includes age-education indicators, as well as the baseline predicted values, Figures 5.22 and 5.23 demonstrate two sets of ratios: (1) the ratio of predicted earnings from the own-effects model (Equation (1), Table 5.3), that restricted cross-quantity effects to be zero, to predicted earnings from the baseline regression that only involves ageeducation-group and year indicators; (2) the ratio of predicted earnings from the model that includes cross-effects (Equation (2), Table 5.6) to predicted earnings from the baseline model that only encompasses age-education-group and year indicators.

Ratios presented in Figures 5.22 and 5.23 show that the observed variations over time have patterns that are more similar to those in predicted earnings from the crosseffects model than from the more restrictive model that excludes them. This finding is clearest for the micro-regions in the Southeastern, Southern, and Center-Western regions (Figure 5.23); but additional calculations for all regions suggest that this result is general, and thus that cross-effects are important. 
Table 5.6. Fixed-Effects Estimates of Equation (2), 1970-2000. Dependent Variable is $\log$ (Monthly Earnings) ${ }^{+}$.

\begin{tabular}{|c|c|c|c|c|c|c|c|c|c|c|c|c|}
\hline \multirow{2}{*}{$\begin{array}{l}\text { Variables } \\
\text { Constant }\end{array}$} & \multicolumn{12}{|c|}{ Coefficients } \\
\hline & $4.26 * * *$ & & & & & & & & & & & \\
\hline 1970 & - & & & & & & & & & & & \\
\hline 1980 & $0.50^{* * *}$ & & & & & & & & & & & \\
\hline 1991 & $0.05 * * *$ & & & & & & & & & & & \\
\hline 2000 & 0.02 & & & & & & & & & & & \\
\hline \multicolumn{13}{|l|}{ Age-education Indicators } \\
\hline $15-24$ years; $0-4$ years of schooling & - & & & & & & & & & & & \\
\hline $15-24$ years; $5-8$ years of schooling & $-1.11^{* * *}$ & & & & & & & & & & & \\
\hline 15-24 years; 9+ years of schooling & $-1.82 * * *$ & & & & & & & & & & & \\
\hline $25-34$ years; 0-4 years of schooling & $2.47^{* * *}$ & & & & & & & & & & & \\
\hline $25-34$ years; $5-8$ years of schooling & 0.89 & & & & & & & & & & & \\
\hline 25-34 years; 9+ years of schooling & $3.02 * * *$ & & & & & & & & & & & \\
\hline $35-49$ years; $0-4$ years of schooling & $2.90^{* * *}$ & & & & & & & & & & & \\
\hline $35-49$ years; $5-8$ years of schooling & $3.20 * *$ & & & & & & & & & & & \\
\hline 35-49 years; $9+$ years of schooling & $5.94 * * *$ & & & & & & & & & & & \\
\hline $50-64$ years; $0-4$ years of schooling & 0.08 & & & & & & & & & & & \\
\hline 50-64 years; 5-8 years of schooling & $9.71 * *$ & & & & & & & & & & & \\
\hline 50-64 years; $9+$ years of schooling & -3.35 & & & & & & & & & & & \\
\hline $\begin{array}{l}\text { Effects of Proportions of Men in the } \\
\text { Following Age-Education Groups } \\
\text { on Groups in Columns: }\end{array}$ & G11 & G12 & G13 & G21 & G22 & G23 & G31 & G32 & G33 & G41 & G42 & G43 \\
\hline 15-24 years; 0-4 years of schooling (G11) & - & $2.81 * * *$ & $4.66^{* * *}$ & $-2.45^{* * * *}$ & 0.72 & -0.31 & $-2.63^{* * * *}$ & -1.16 & $-2.43 *$ & 0.15 & $-7.67 * *$ & $7.75^{* *}$ \\
\hline 15-24 years; 5-8 years of schooling (G12) & $1.64 * * *$ & - & $1.63^{*}$ & 0.38 & -0.16 & $-2.51 * *$ & 0.13 & -1.48 & $-3.71 * *$ & $3.22 * * *$ & $-8.65 * *$ & $7.16^{* *}$ \\
\hline 15-24 years; 9+ years of schooling (G13) & $0.91 *$ & 0.68 & - & -0.68 & $1.51 *$ & -1.27 & -0.55 & -0.52 & $-2.69 *$ & $2.87 * * *$ & $-5.67 *$ & $5.27 *$ \\
\hline $25-34$ years; 0-4 years of schooling (G21) & $2.31 * * *$ & $2.79 * * *$ & $2.37 * * *$ & - & 1.42 & -1.25 & $-1.07^{*}$ & -1.73 & $-3.35^{* *}$ & $1.54 * * *$ & $-9.29 * *$ & 4.03 \\
\hline 25-34 years; 5-8 years of schooling (G22) & $2.47^{* * *}$ & $7.26^{* * *}$ & $5.45^{* * *}$ & -0.95 & - & $-1.81^{*}$ & -0.08 & -2.11 & -1.81 & $1.92 * *$ & $-9.43 * *$ & 4.82 \\
\hline 25-34 years; 9+ years of schooling (G23) & $-3.02 * * *$ & -0.51 & $4.53^{* * * *}$ & $-3.04 * * *$ & -1.81 & - & $-2.42 * *$ & -1.44 & $-4.98 * *$ & -1.02 & $-7.30 *$ & $5.51 *$ \\
\hline $35-49$ years; $0-4$ years of schooling $(\mathrm{G} 31)$ & $0.82^{*}$ & $1.77 * * *$ & $4.70^{* * * *}$ & -0.46 & $2.50 * *$ & $2.31 * *$ & - & 1.94 & -2.21 & $2.93^{* * * *}$ & -3.90 & $7.14 * *$ \\
\hline 35-49 years; 5-8 years of schooling (G32) & $4.60 * * *$ & $3.95 * * *$ & $6.21 * * *$ & 1.47 & $4.37 * *$ & 1.56 & 0.15 & - & $-3.72 *$ & $3.07^{* *}$ & $-8.64 *$ & $9.34 * * *$ \\
\hline 35-49 years; 9+ years of schooling (G33) & $3.84 * * *$ & $6.06 * * *$ & $5.95^{* * * *}$ & -0.33 & $3.07^{*}$ & 0.58 & -0.19 & -0.55 & - & $3.50 * *$ & -5.25 & $12.53^{* * * *}$ \\
\hline 50-64 years; 0-4 years of schooling (G41) & 0.23 & $2.61 * * *$ & $2.23 * * *$ & $-2.50 * * *$ & 0.03 & $-2.65 * *$ & $-2.89 * * *$ & $-2.39 *$ & $-3.78 * *$ & - & $-7.44 * *$ & $6.51^{* *}$ \\
\hline 50-64 years; 5-8 years of schooling (G42) & $-8.90^{* * *}$ & -0.67 & -1.50 & $-11.23 * * *$ & $-7.52 * *$ & 1.47 & $-10.95^{* * *}$ & $-7.67 * *$ & -4.29 & -2.25 & - & 3.33 \\
\hline 50-64 years; $9+$ years of schooling $(\mathrm{G} 43)$ & 0.73 & -1.39 & 2.75 & -0.54 & -0.81 & 0.75 & $-4.39 *$ & -3.57 & -3.16 & -2.06 & $-17.79 * * *$ & - \\
\hline $\mathrm{N}$ observations & 19,727 & & & & & & & & & & & \\
\hline $\mathrm{N}$ groups & 502 & & & & & & & & & & & \\
\hline Rho: Fraction of variance due to the $v_{i}$ & 0.68 & & & & & & & & & & & \\
\hline $\mathrm{F}(146 ; 19,079):$ All coefficients $=0$ & $1,808.52 * * *$ & & & & & & & & & & & \\
\hline $\mathrm{F}(501 ; 19,079)$ : Area fixed effects $=0$ & $20.82 * * *$ & & & & & & & & & & & \\
\hline
\end{tabular}

${ }^{*}$ Significant at $\mathrm{p}<.05 ;{ }^{* *}$ Significant at $\mathrm{p}<.01 ;{ }^{* * *}$ Significant at $\mathrm{p}<.001$.

${ }^{+}$Nominal income was converted to base 1 in January 2002, taking into account changes in currency and inflation.

Source: 1970-2000 Brazilian Censuses. 
Figure 5.22. Ratios of Observed Earnings, of Predicted Earnings from Equation (1), and of Predicted Earnings from Equation (2), to Predicted Earnings from Table 5.2, Males Ages 35-49 with 5-8 Years of Education, 1970-2000, Selected Micro-regions (Northeast).
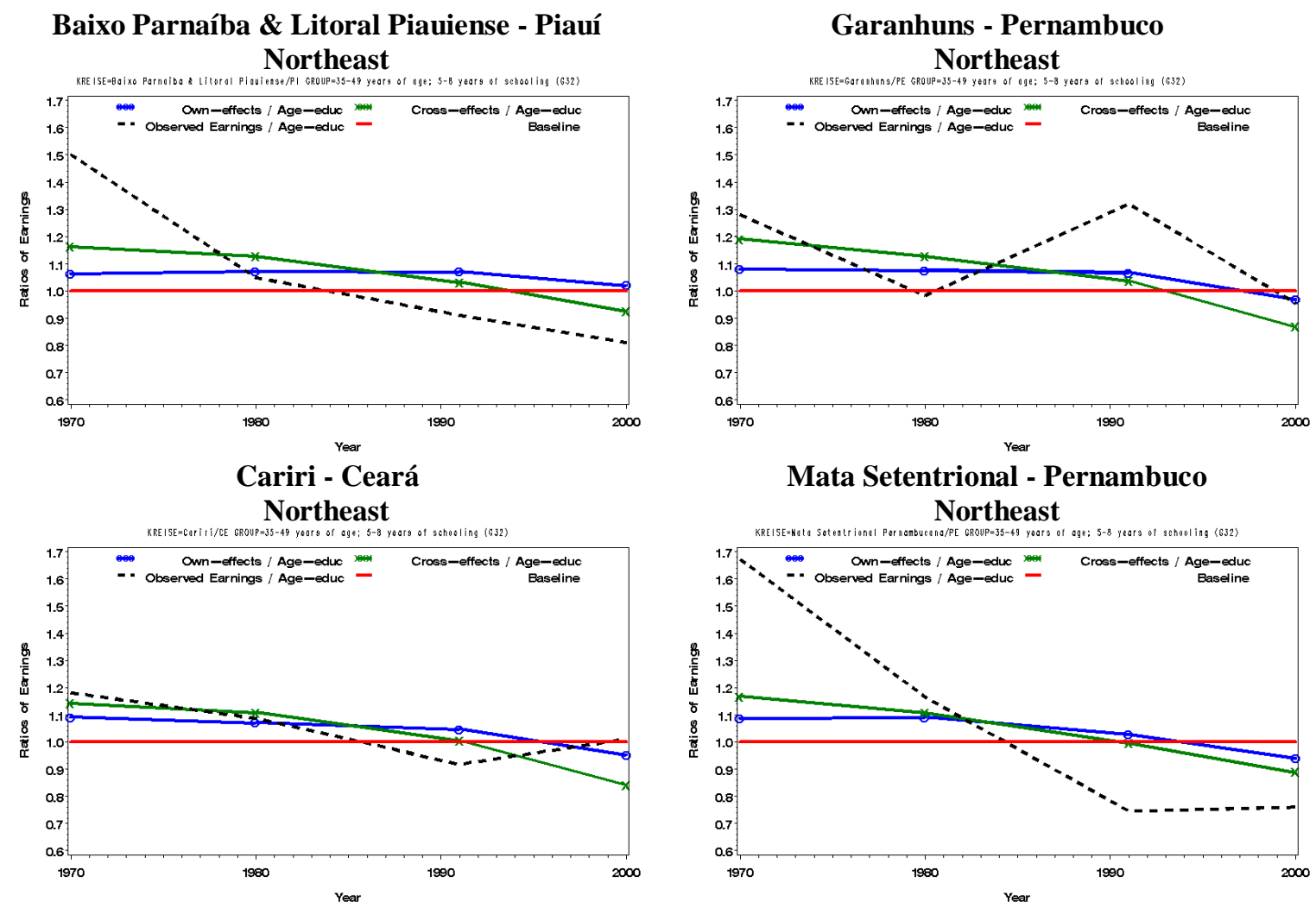

Campina Grande - Paraíba Northeast
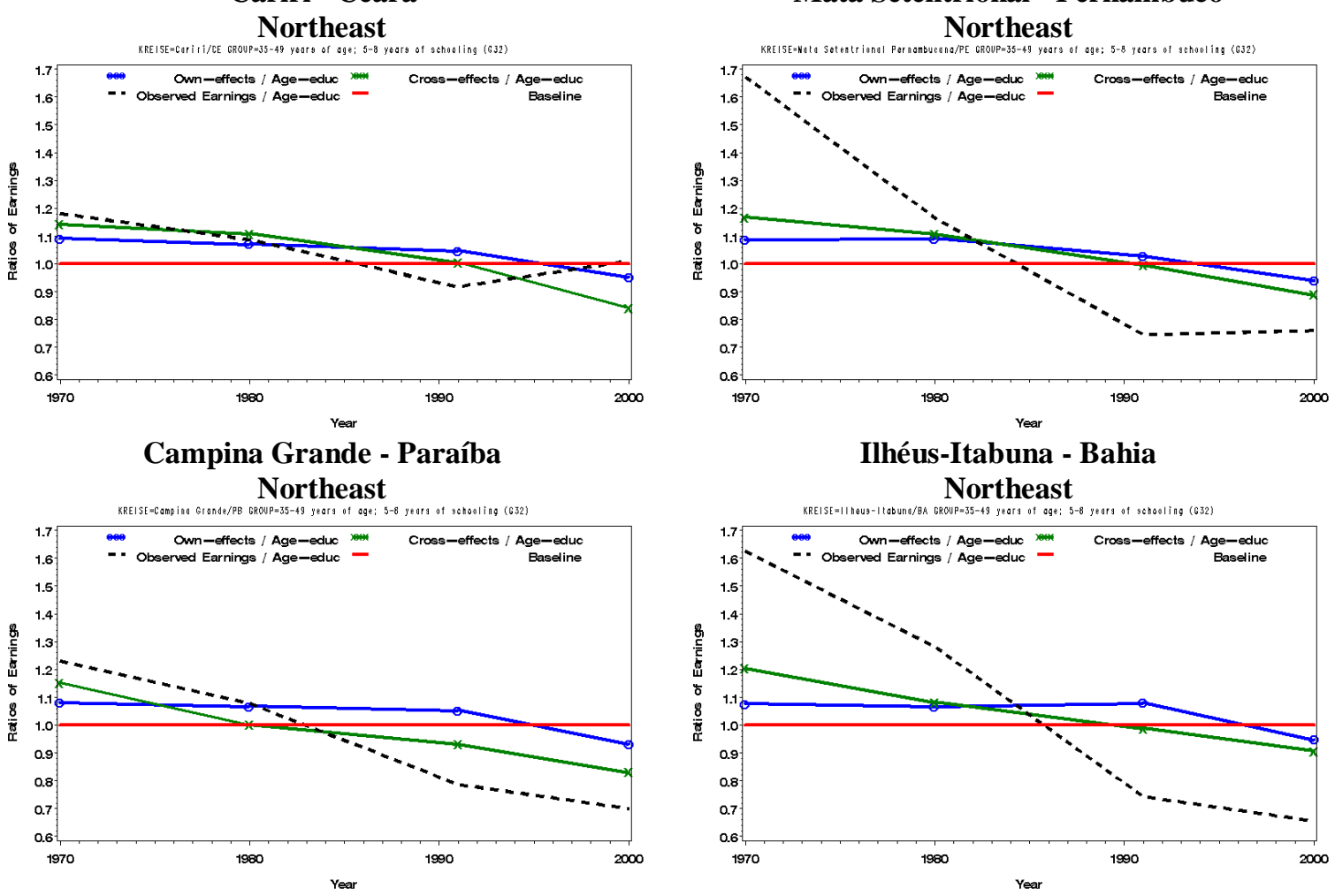

Source: 1970-2000 Brazilian Censuses. 
Figure 5.23. Ratios of Observed Earnings, of Predicted Earnings from Equation (1), and of Predicted Earnings from Equation (2), to Predicted Earnings from Table 5.2, Males Ages 35-49 with 5-8 Years of Education, 1970-2000, Selected Micro-regions (Southeast, South, Center-West).
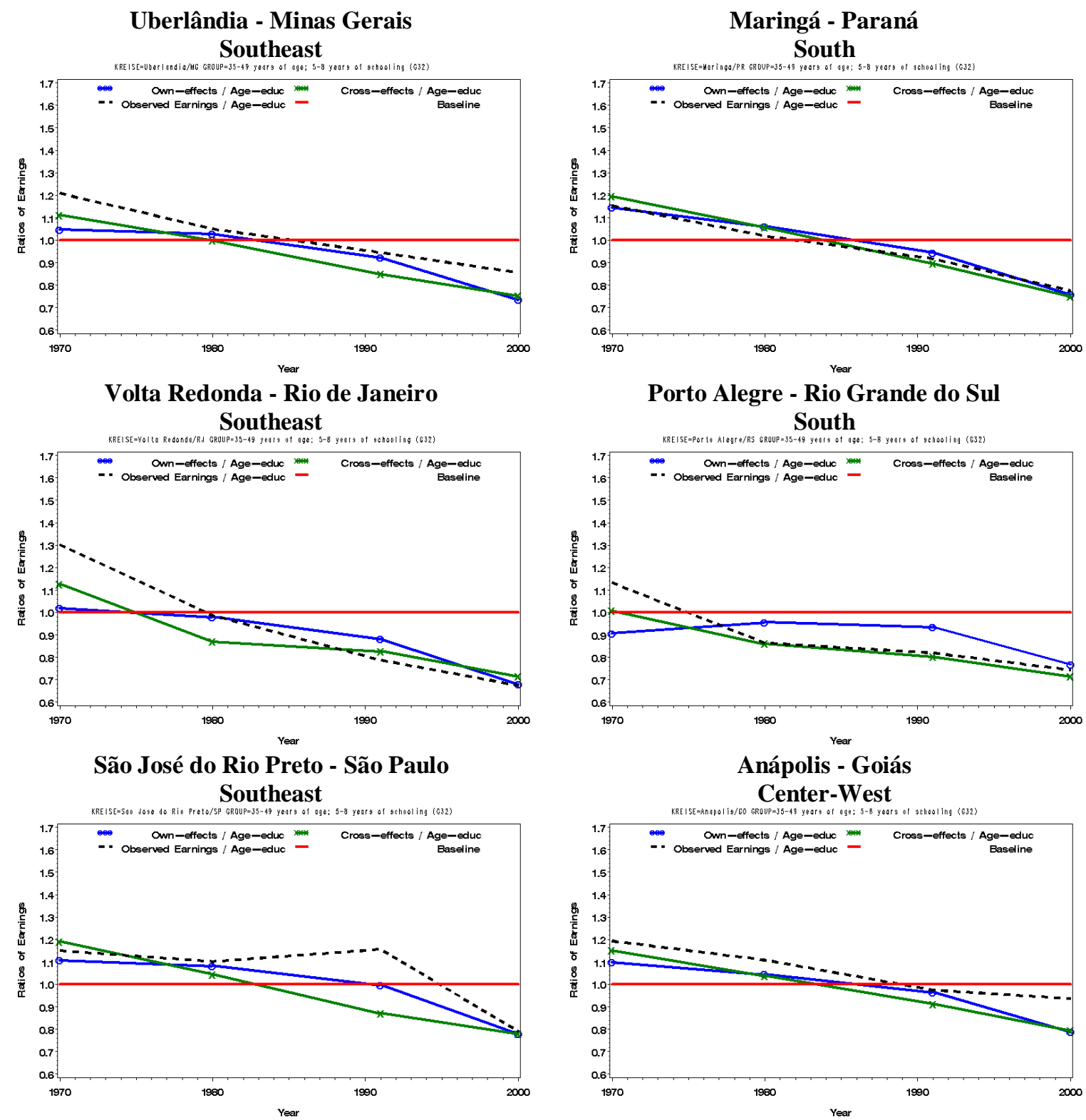

Source: 1970-2000 Brazilian Censuses. 
Estimates of the coefficients in Equation (2') are not presented in tabular format because the excessive number of coefficients (543 in total) makes it too complicated to interpret the results. An interpretation of estimates of Equation (2') can be done in comparison to estimates of Equation (1') in Figures 5.24 and 5.25, such as was done in previous figures.

In general, as before, observed variations in earnings over time have patterns that are more similar to those predicted from the cross-effects model interacted with time (Equation (2')) than those from the more restrictive own-effect model, also including interactions with time (Equation (1')). The predicted values better fit the observed values for the Southeastern, Southern and Center-Western regions (Figure 5.25), as observed above.

The same set of ratios of Equation (2') can be compared with those originating from estimates of Equation (2) in Figures 5.26 and 5.27. The inclusion of interactions between Censuses year and cross-effects generated predicted earnings that better fit the observed data.

However, it is noticeable that the predicted earnings of all these models have a more similar pattern to the observed variations in the Southeastern, Southern and Center-Western regions, which experienced greater demographic and educational transitions compared to the Northeastern regions. A way to control for this variation, and get predicted earnings that better fit the observed values, would be through the inclusion of interactions between region indicators (North, Northeast, Southeast, South and Center-West) and the aforementioned proportions: $\beta_{1}$ (own-effects), $\beta_{2}$ (cross-effects), $\beta_{3}$ (interactions of owneffects with time indicators), and $\beta_{4}$ (interactions of cross-effects with time indicators). 
Figure 5.24. Ratios of Observed Earnings, of Predicted Earnings from Equation (1'), and of Predicted Earnings from Equation (2'), to Predicted Earnings from Table 5.2, Males Ages 35-49 with 5-8 Years of Education, 1970-2000, Selected Micro-regions (Northeast).
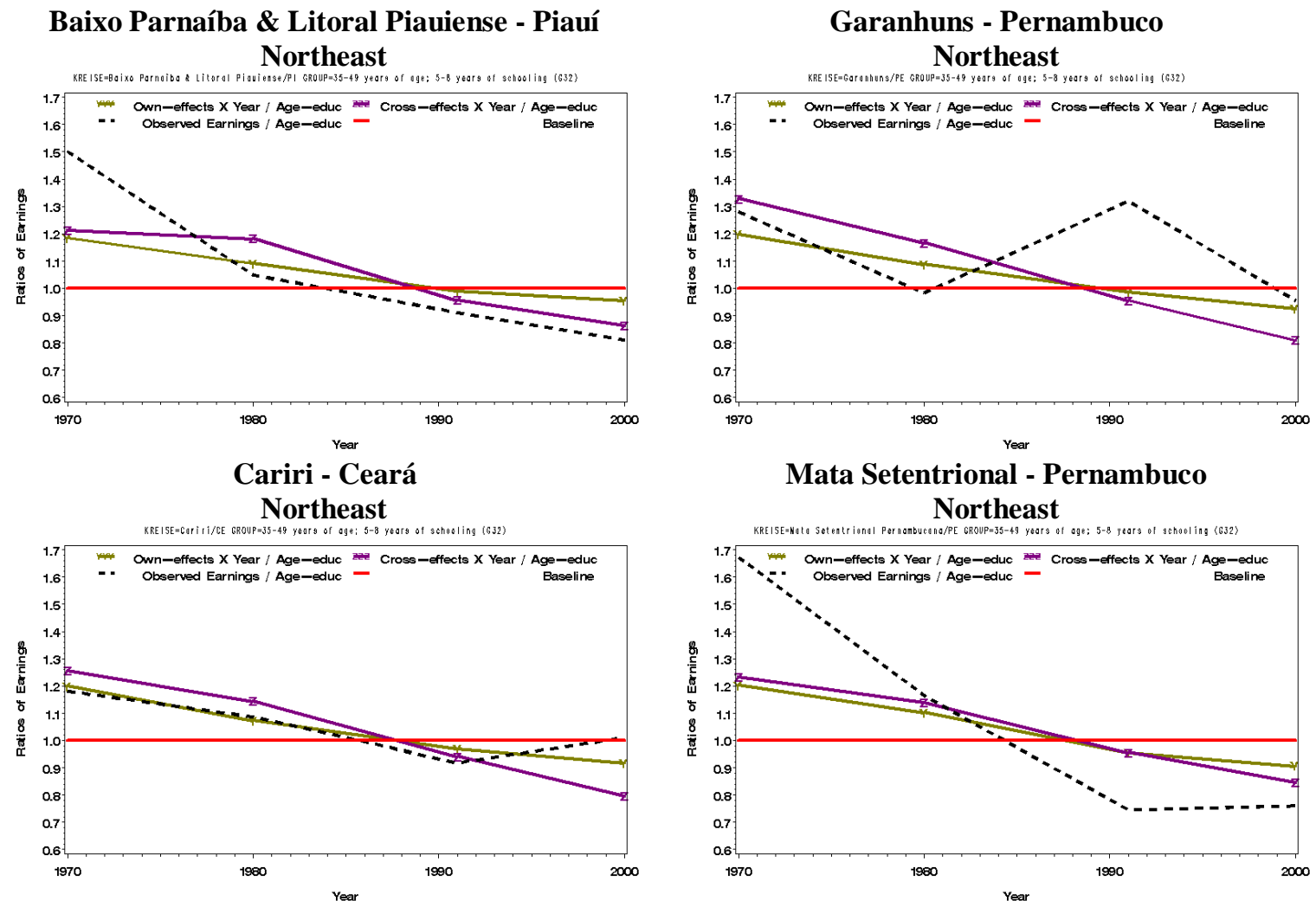

Campina Grande - Paraíba

Northeast

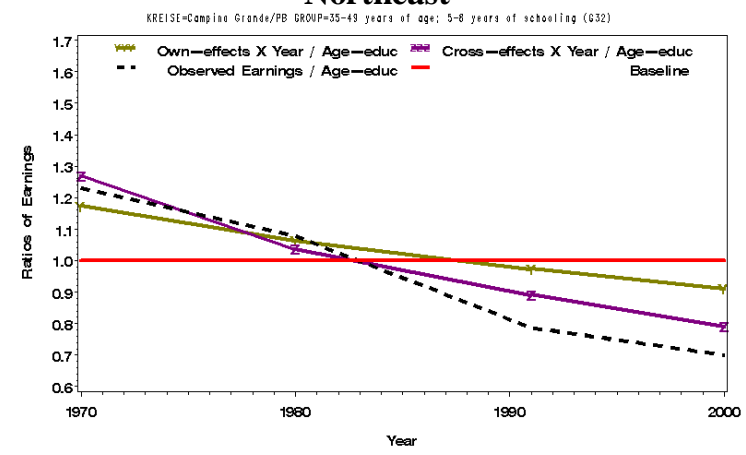

Mata Setentrional - Pernambuco Northeast

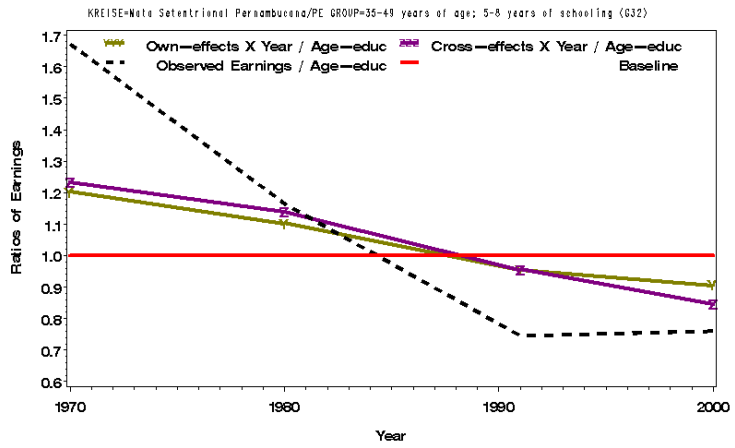

Ilhéus-Itabuna - Bahia Northeast

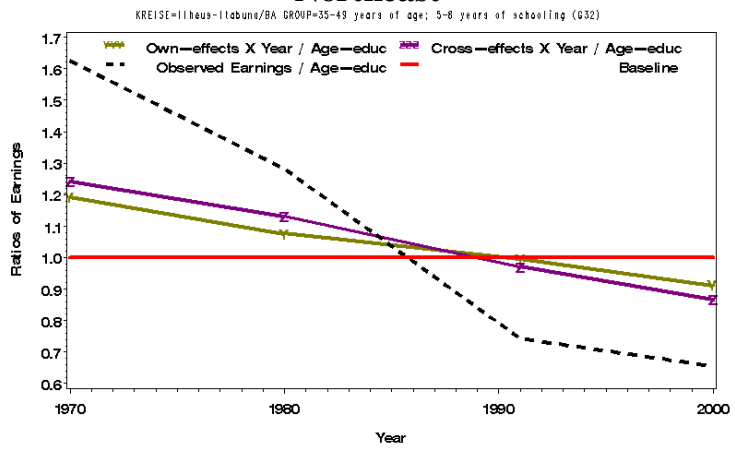

Source: 1970-2000 Brazilian Censuses. 
Figure 5.25. Ratios of Observed Earnings, of Predicted Earnings from Equation (1'), and of Predicted Earnings from Equation (2'), to Predicted Earnings from Table 5.2, Males Ages 35-49 with 5-8 Years of Education, 1970-2000, Selected Micro-regions (Southeast, South, Center-West).
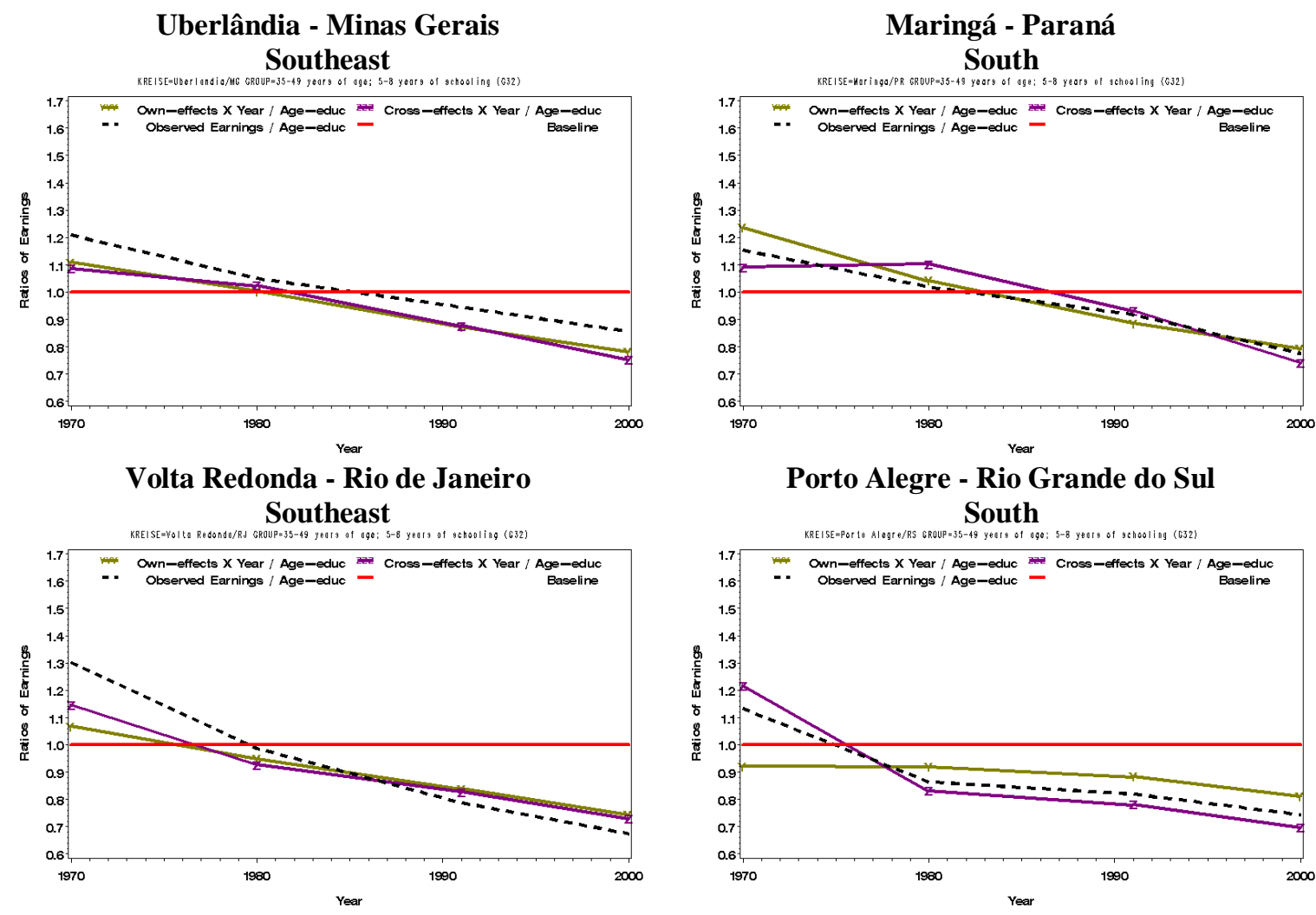

São José do Rio Preto - São Paulo Southeast

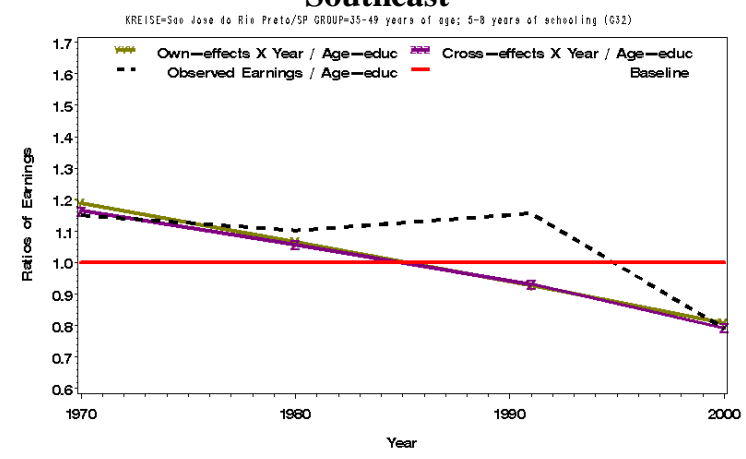

Anápolis - Goiás Center-West

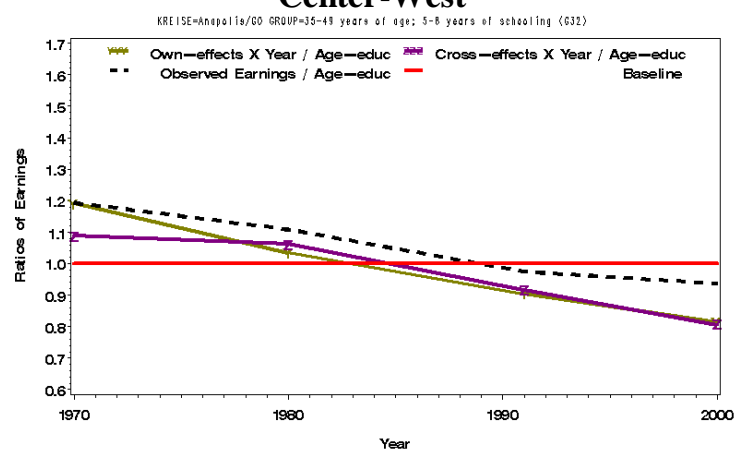

Source: 1970-2000 Brazilian Censuses. 
Figure 5.26. Ratios of Observed Earnings, of Predicted Earnings from Equation (2), and of Predicted Earnings from Equation (2'), to Predicted Earnings from Table 5.2, Males Ages 35-49 with 5-8 Years of Education, 1970-2000, Selected Micro-regions (Northeast).
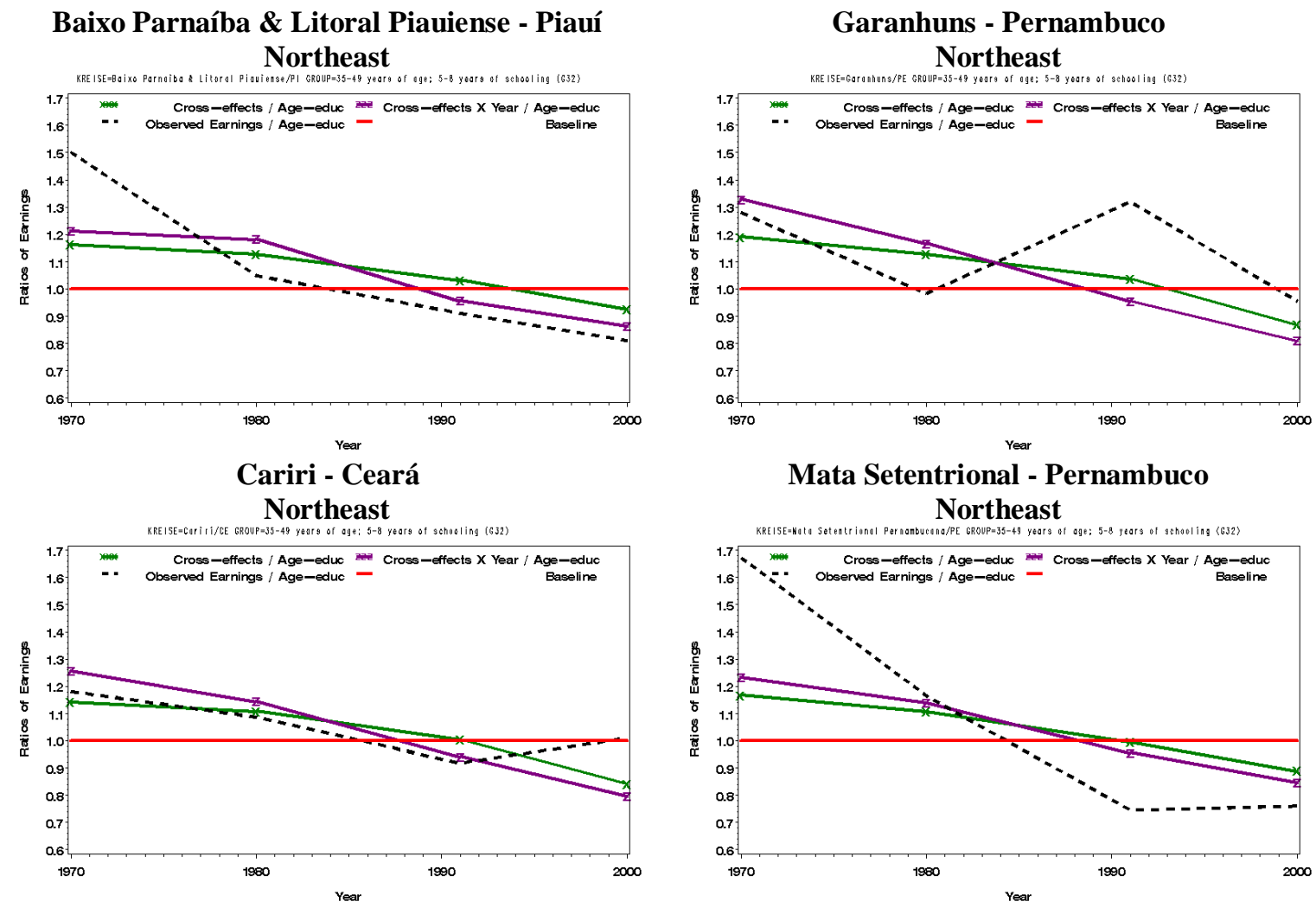

Campina Grande - Paraíba

Northeast

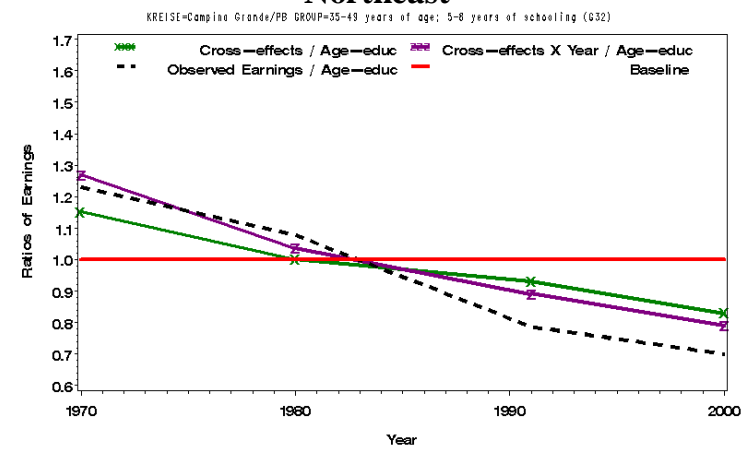

Mata Setentrional - Pernambuco Northeast

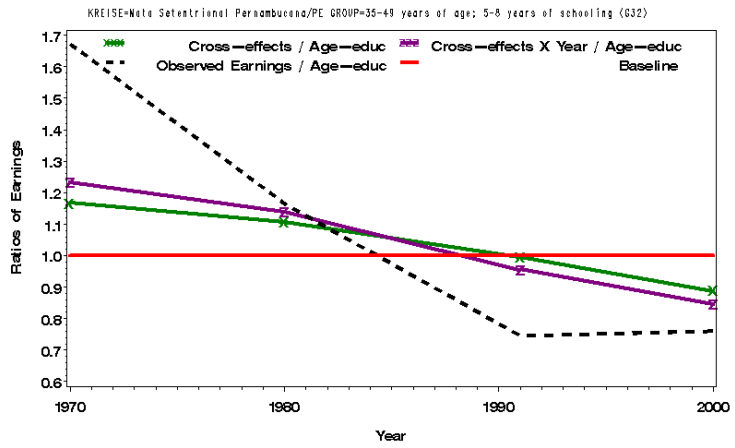

Ilhéus-Itabuna - Bahia Northeast

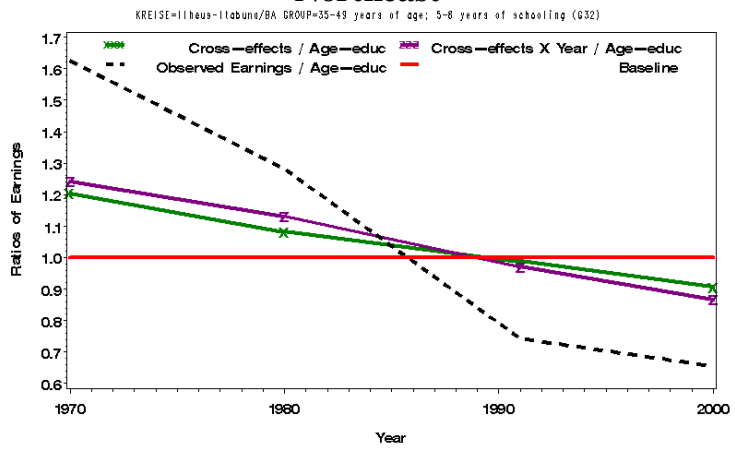

Source: 1970-2000 Brazilian Censuses. 
Figure 5.27. Ratios of Observed Earnings, of Predicted Earnings from Equation (2), and of Predicted Earnings from Equation (2'), to Predicted Earnings from Table 5.2, Males Ages 35-49 with 5-8 Years of Education, 1970-2000, Selected Micro-regions (Southeast, South, Center-West).
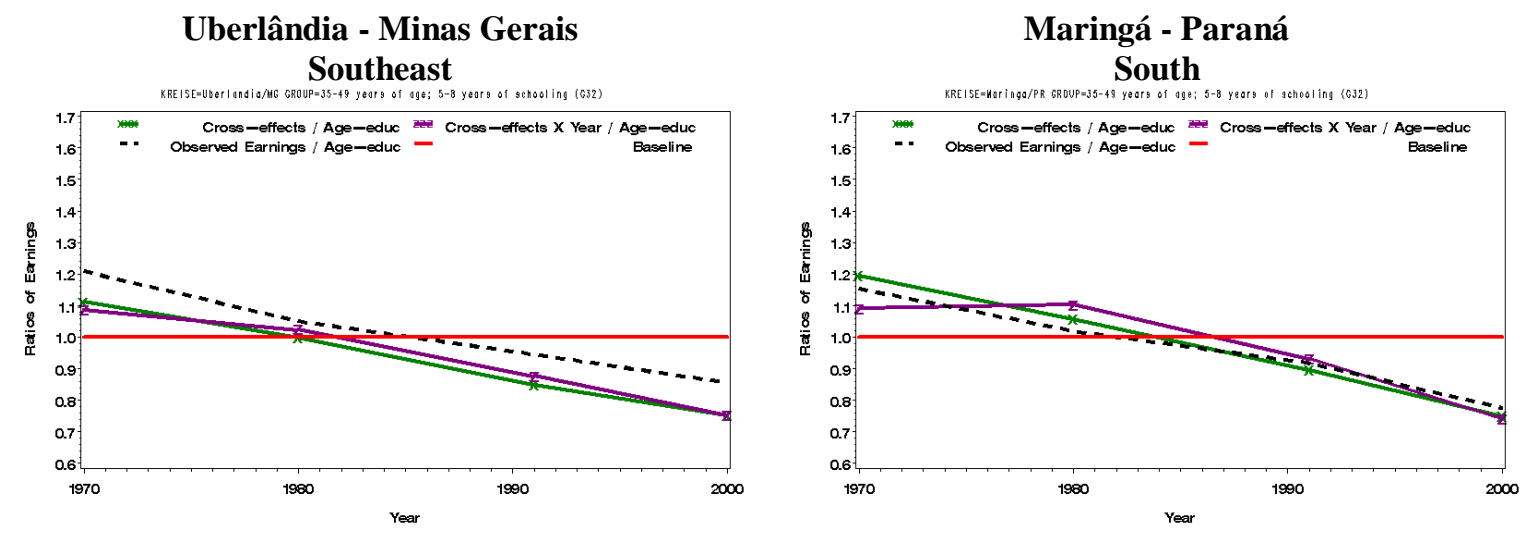

Volta Redonda - Rio de Janeiro Southeast

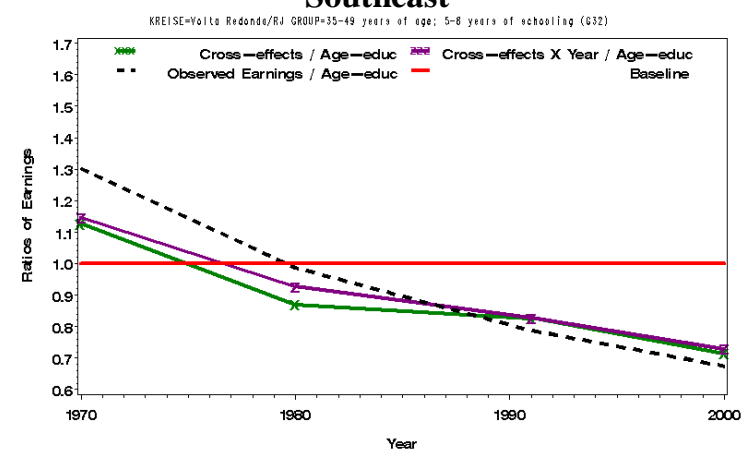

São José do Rio Preto - São Paulo Southeast
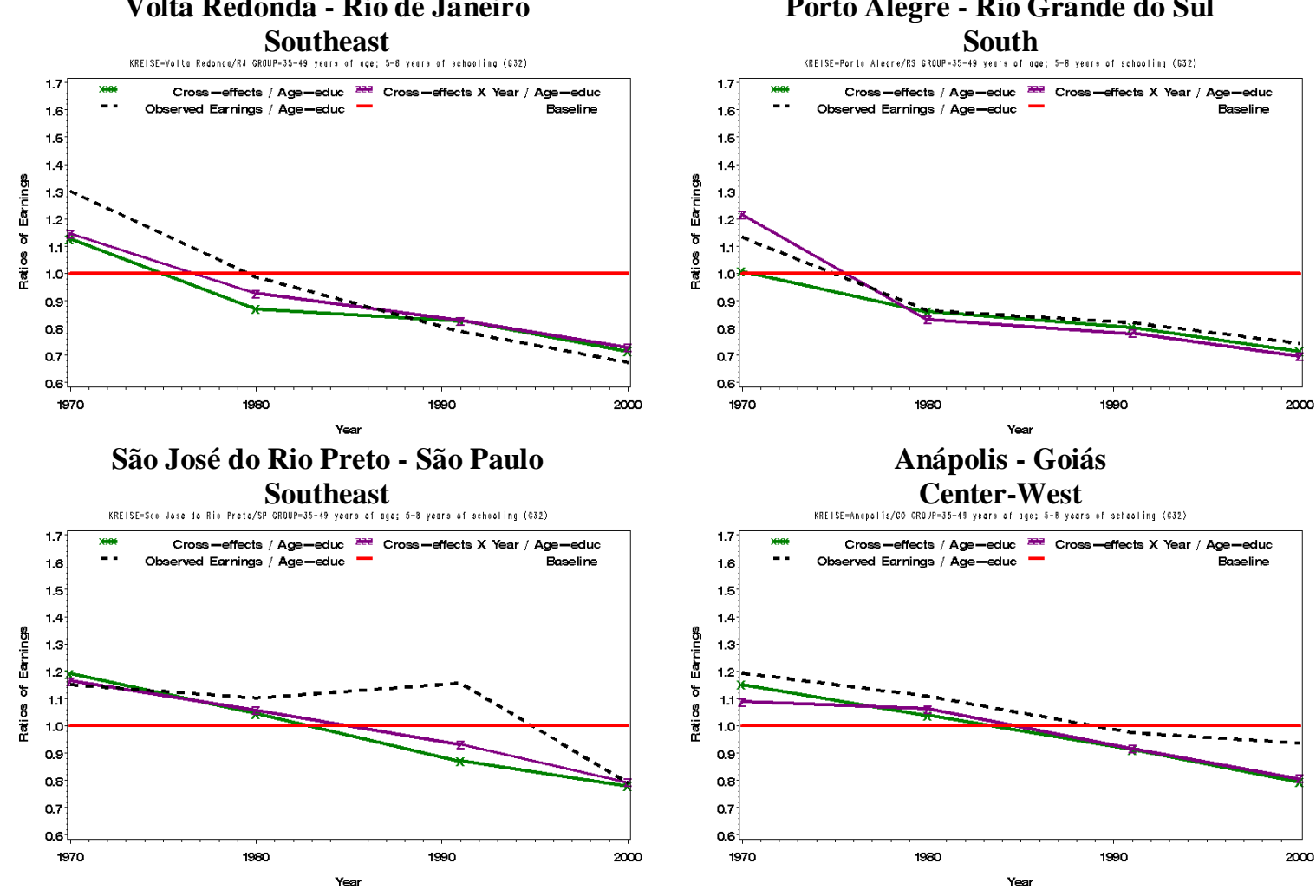

Anápolis - Goiás

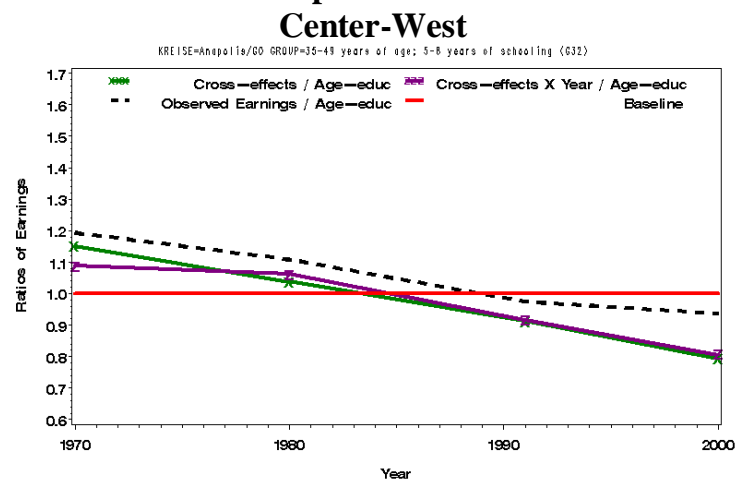

Source: 1970-2000 Brazilian Censuses. 


\section{THE INFLUENCE OF BRAZILIAN MAJOR REGIONS}

Equations (1), (1'), (2) and (2') were re-estimated including interactions of the quantity terms with five region indicators: North, Northeast, Southeast, South and CenterWest (one is taken as reference). The number of coefficients in these new equations is very large. The new estimates generate a total of 67 coefficients in Equation (1) after the addition of interactions with region indicators; 211 in Equation (1') including the new interactions; 547 in Equation (2); and 2,131 in Equation (2'). Because of the difficulty of interpreting them, the estimates will be shown in graphical format only, and not in tabular format.

Figures 5.28 and 5.29 illustrate: (1) the ratio between observed and predicted earnings from the model that only includes age-education indicators; (2) the baseline predicted values from the model that only includes age-education indicators (Table 5.2); (3) the ratio of predicted earnings from the own-effects model (Equation (1), Table 5.3) to the predicted earnings from the baseline regression; (2) the ratio of predicted earnings from the model that includes own-effects interacted with region indicators to predicted earnings from the baseline. Estimates of the model incorporating interactions with region indicators show a slightly better fit to the observed variations than estimates of Equation (1).

Figures 5.30 and 5.31 demonstrate interesting results for ratios of Equation (1') (Table 5.4) and Equation (1') including interactions with region indicators. The new estimates show that predicted earnings from the model that includes own-effects interacted with year and region indicators, have patterns that follow much more closely with the ones of observed earnings. The improvement in prediction is clear for the Northeastern areas (Figure 5.30), in which predicted values now have more similar patterns to those in observed earnings at the beginning of the period (1970). 
Figure 5.28. Ratios of Observed Earnings, of Predicted Earnings from Equation (1), and of Predicted Earnings from Equation (1) Including Interactions With Region Indicators, to Predicted Earnings from Table 5.2, Males Ages 35-49 with 58 Years of Education, 1970-2000, Selected Micro-regions (Northeast).
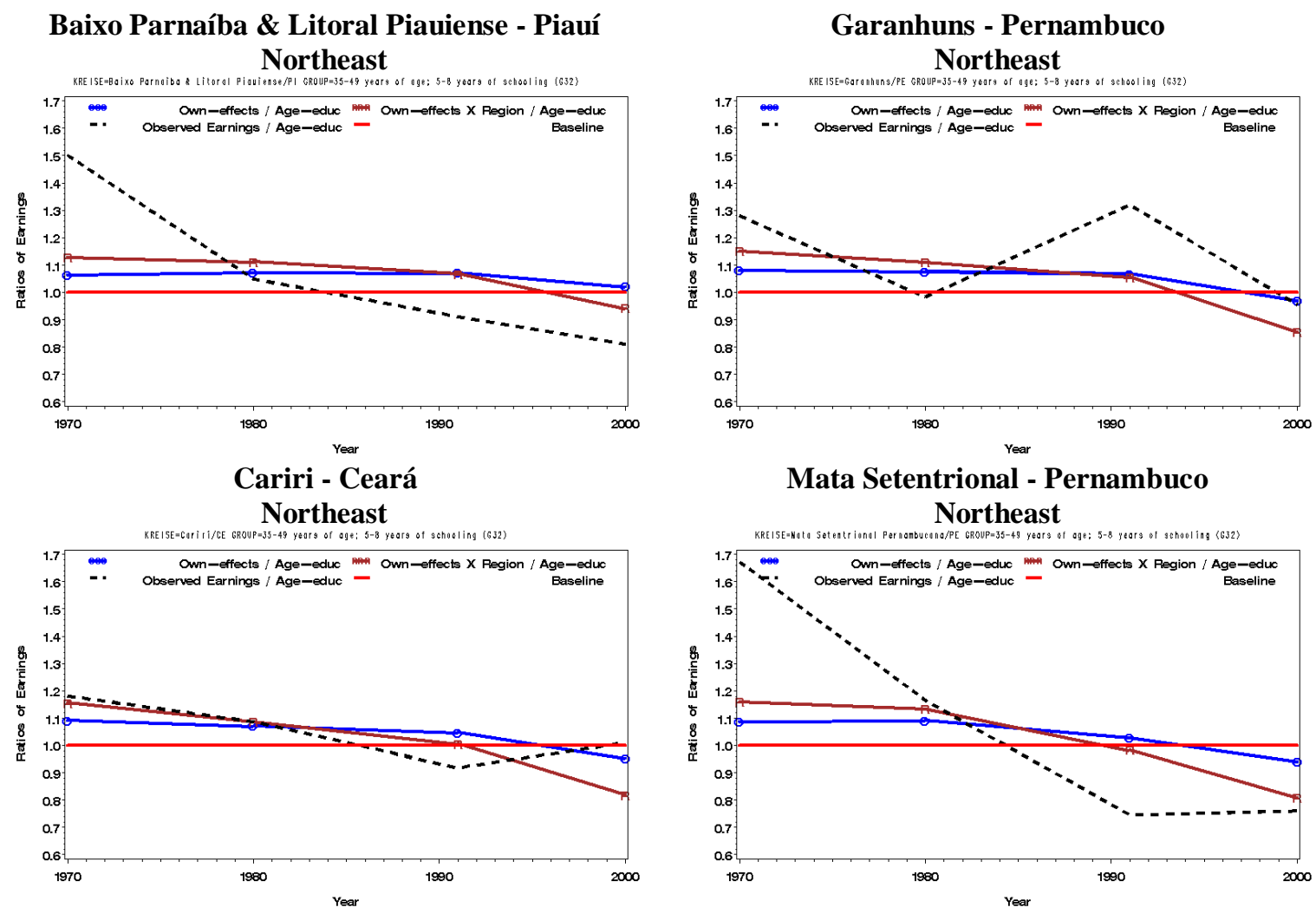

Campina Grande - Paraíba

Northeast

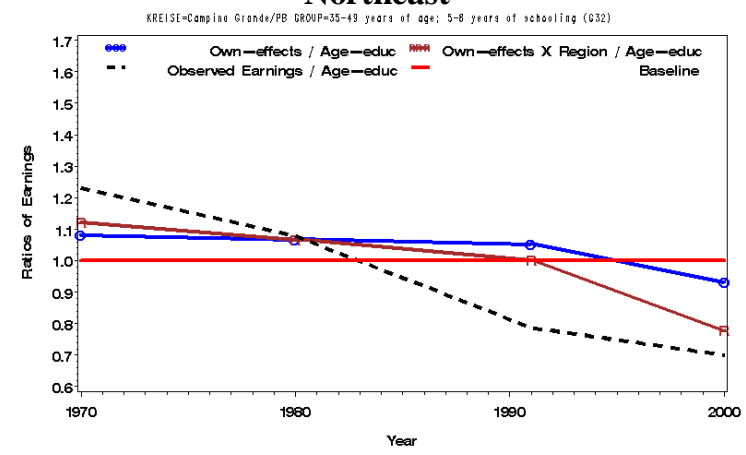

Mata Setentrional - Pernambuco Northeast

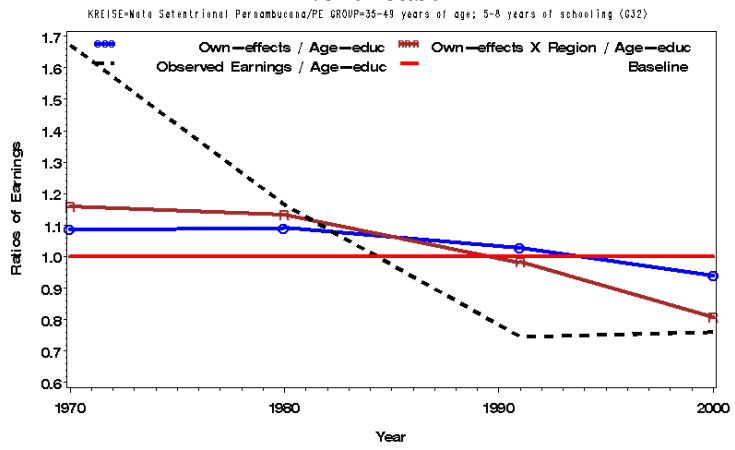

Ilhéus-Itabuna - Bahia

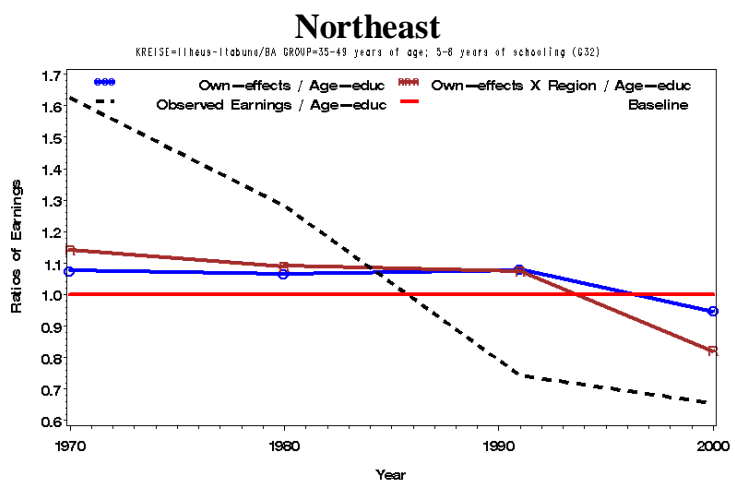

Source: 1970-2000 Brazilian Censuses. 
Figure 5.29. Ratios of Observed Earnings, of Predicted Earnings from Equation (1), and of Predicted Earnings from Equation (1) Including Interactions With Region Indicators, to Predicted Earnings from Table 5.2, Males Ages 35-49 with 58 Years of Education, 1970-2000, Selected Micro-regions (Southeast, South, Center-West).
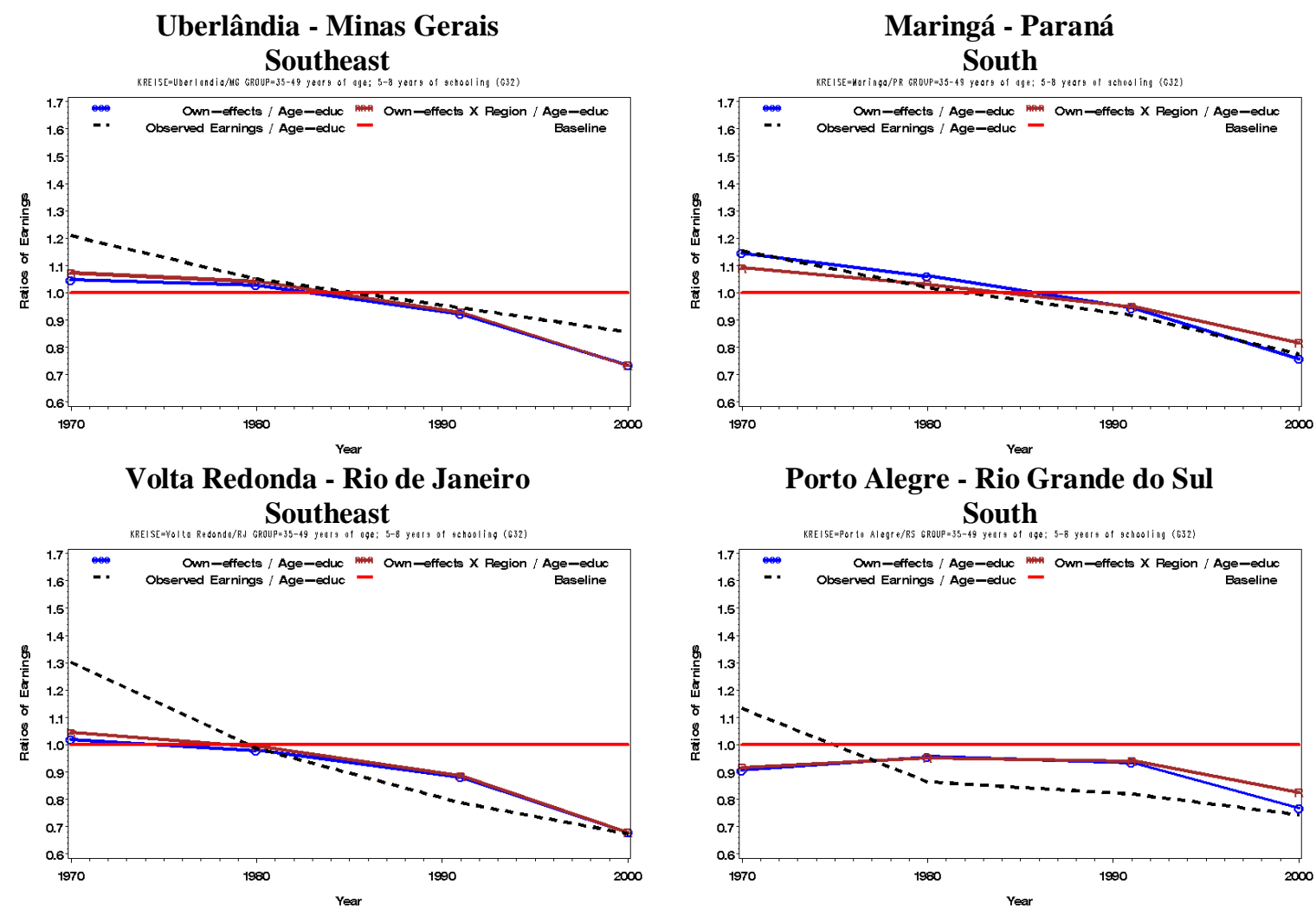

São José do Rio Preto - São Paulo Southeast
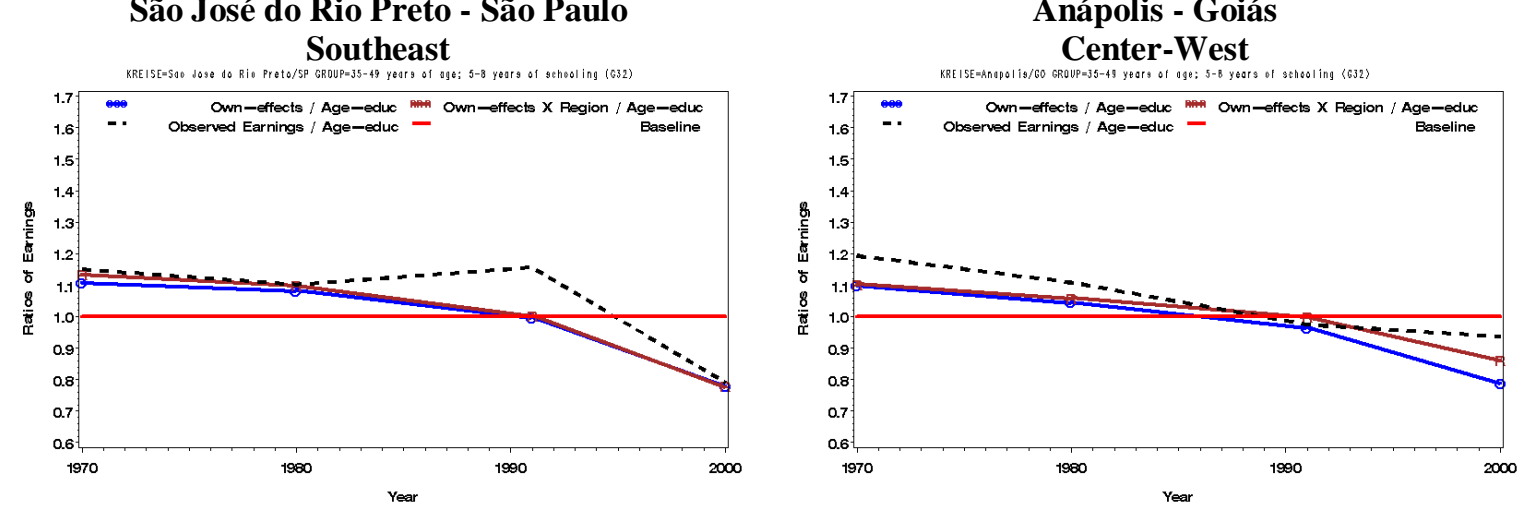

Source: 1970-2000 Brazilian Censuses. 
Figure 5.30. Ratios of Observed Earnings, of Predicted Earnings from Equation (1'), and of Predicted Earnings from Equation (1') Including Interactions With Region Indicators, to Predicted Earnings from Table 5.2, Males Ages 35-49 with 5-8 Years of Education, 1970-2000, Selected Micro-regions (Northeast).

\section{Baixo Parnaíba \& Litoral Piauiense - Piauí} Northeast

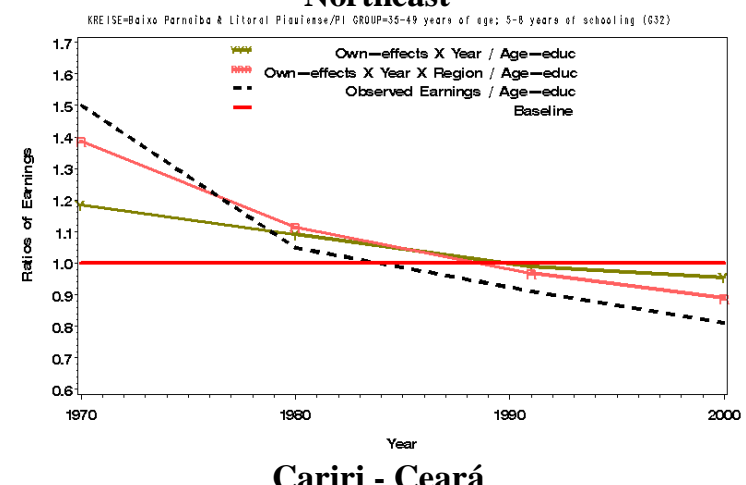

Cariri - Ceará

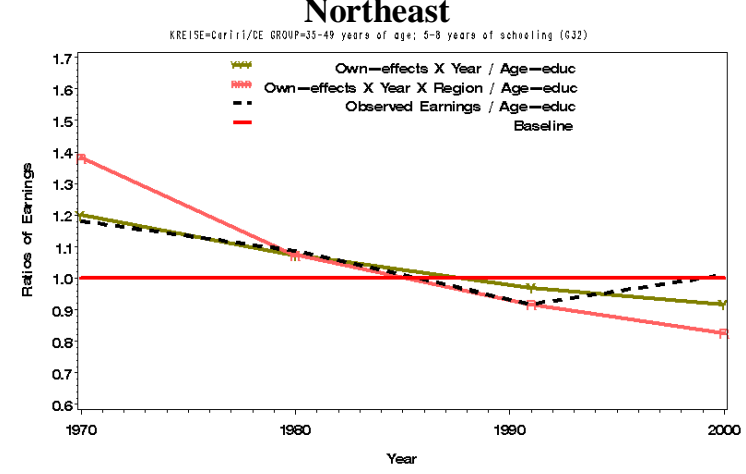

Campina Grande - Paraíba

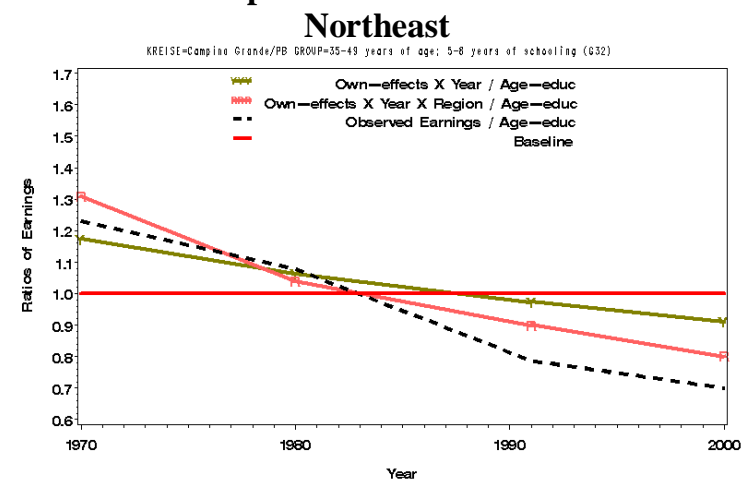

Source: 1970-2000 Brazilian Censuses.

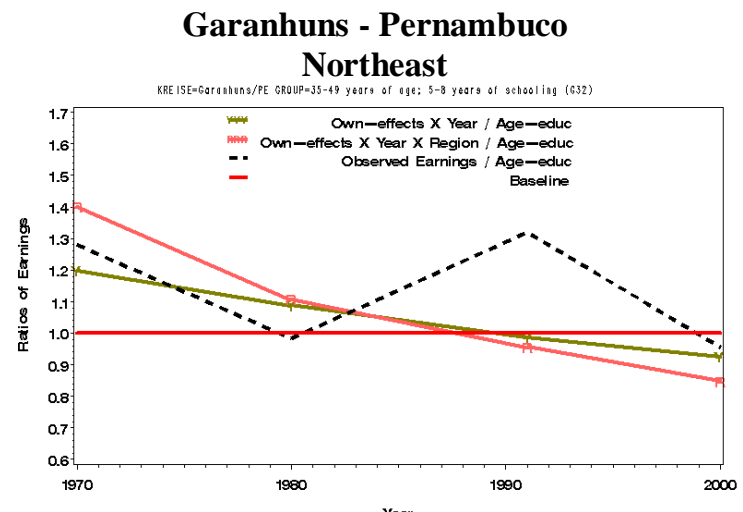

Mata Setentrional - Pernambuco

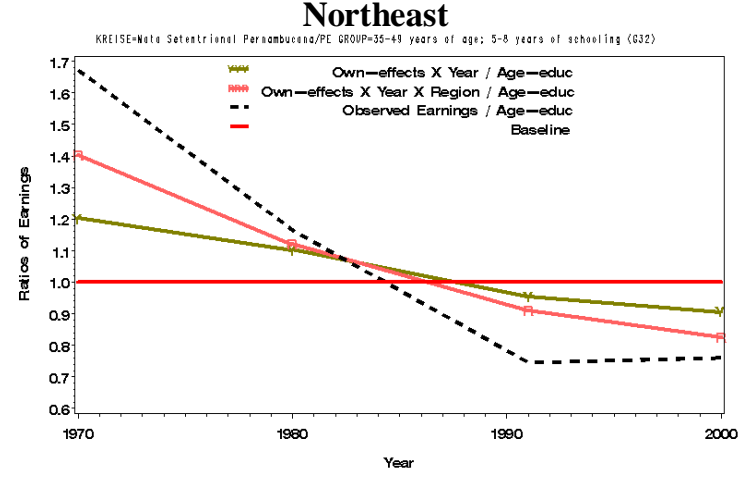

Ilhéus-Itabuna - Bahia

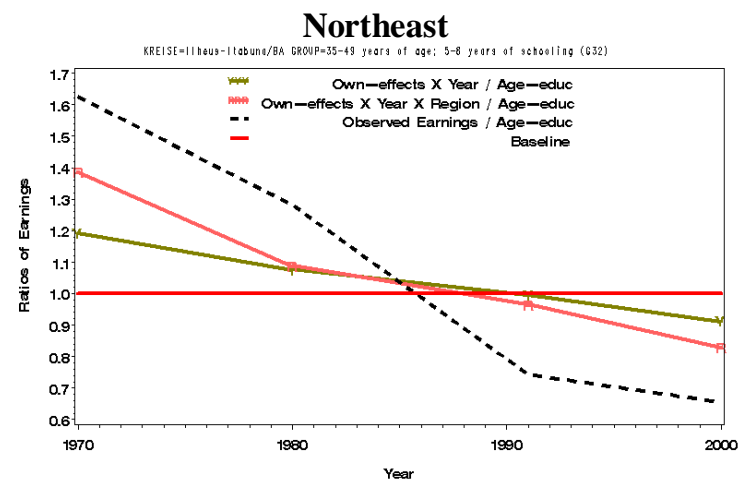


Figure 5.31. Ratios of Observed Earnings, of Predicted Earnings from Equation (1'), and of Predicted Earnings from Equation (1') Including Interactions With Region Indicators, to Predicted Earnings from Table 5.2, Males Ages 35-49 with 5-8 Years of Education, 1970-2000, Selected Micro-regions (Southeast, South, Center-West).
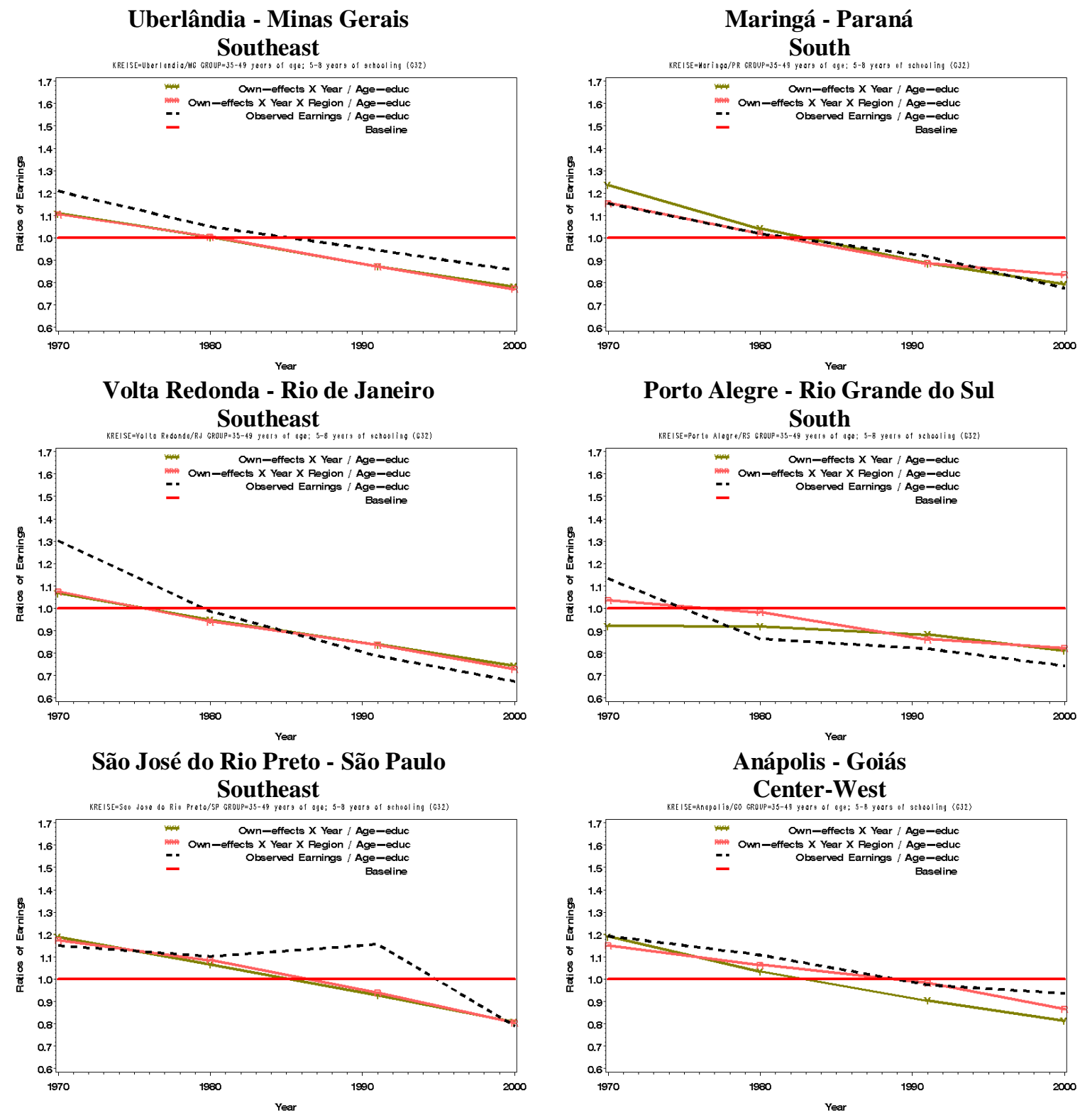

Source: 1970-2000 Brazilian Censuses. 
Figures 5.32 and 5.33 illustrate: (1) ratios of predicted earnings from the crosseffects model (Equation (2), Table 5.6) to the predicted earnings from the model that includes only age-education and year indicators; (2) ratios of predicted earnings from the model that includes cross-effects interacted with region indicators to predicted earnings from the baseline model; (3) ratios of observed earnings to the baseline model; and (4) the baseline for comparison reasons. The new estimates of the model including interactions with region indicators do not improve significantly the fit to the observed variations when comparing to estimates of Equation (2). The fit observed by the new estimates of owneffects interacted with year and region indicators in Figures 5.30 and 5.31 indicate that a better fit might be observed if cross-quantity terms are allowed to vary both over regions and time.

Figures 5.34 and 5.35 show ratios of estimates from Equation (2') and Equation (2') including interaction with region indicators to estimates from the baseline model. The interesting result is that micro-regions located in the Northeast region, which has been experiencing slower demographic and educational transitions compared to the Southeastern and Southern regions, have predicted earnings that better fit the data from the model that only includes own-effects interacted with region (Figure 5.30) than from the model that has cross-effects interacted with region (Figure 5.34). This is in line with previous studies that estimated small cross-elasticities of complementarity, meaning that exogenous changes in the demographic structure of the labor force do not have large effects on the relative wages of other groups (Hamermesh 1993, chapter 3). Even with statistically significant cross-effects observed in Equations (2) and (2'), it seems that these effects do not have a great impact on earnings, generating predictions that do not better fit the data in comparison to those of own-effects models. 
Figure 5.32. Ratios of Observed Earnings, of Predicted Earnings from Equation (2), and of Predicted Earnings from Equation (2) Including Interactions With Region Indicators, to Predicted Earnings from Table 5.2, Males Ages 35-49 with 58 Years of Education, 1970-2000, Selected Micro-regions (Northeast).
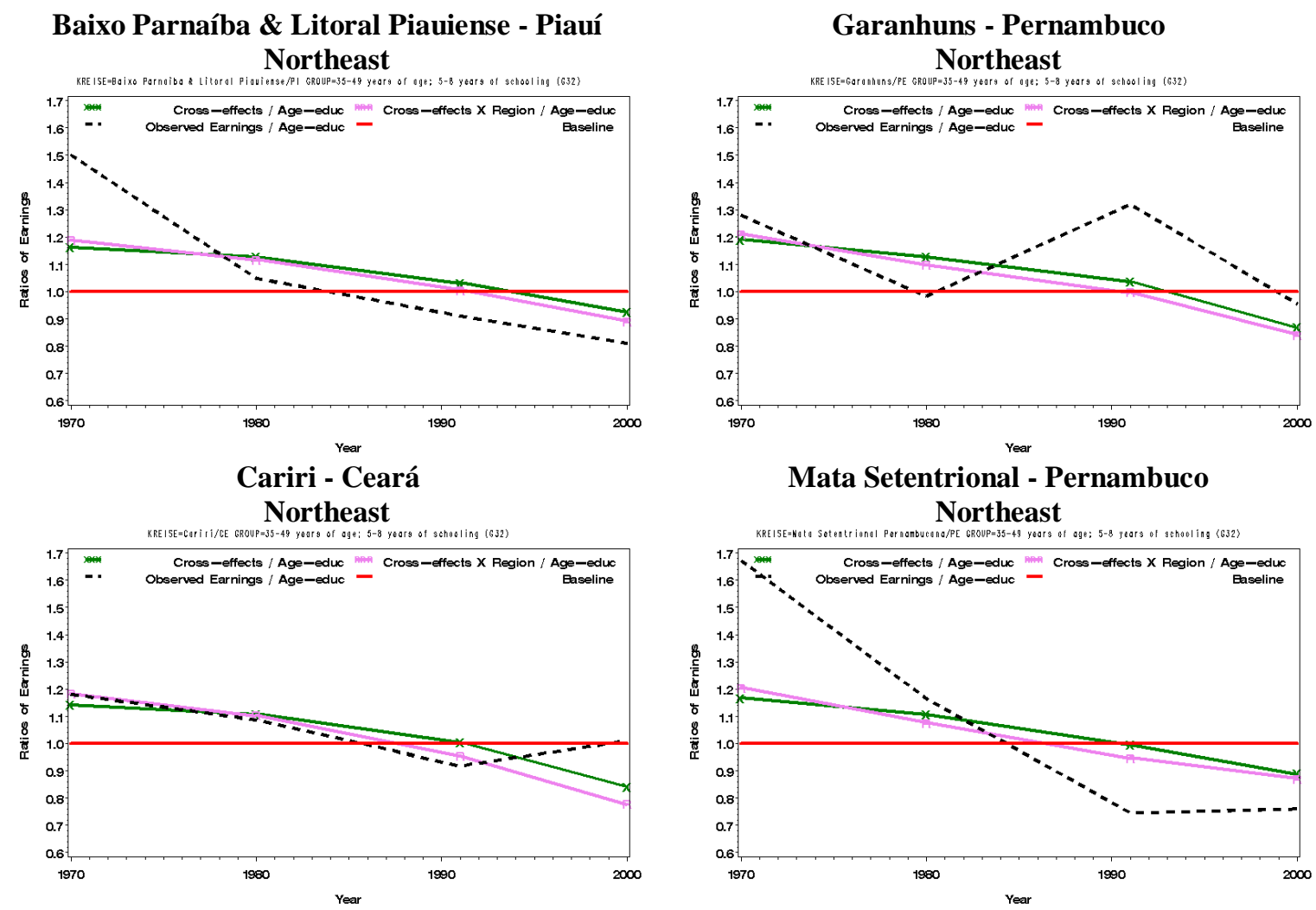

Campina Grande - Paraíba

Northeast

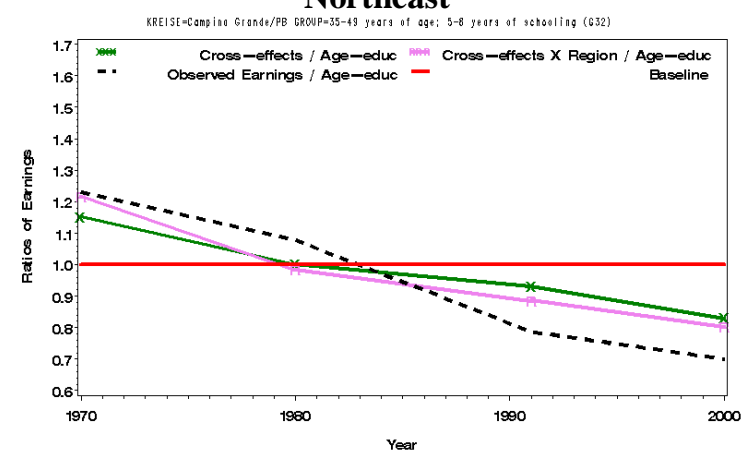

Mata Setentrional - Pernambuco Northeast

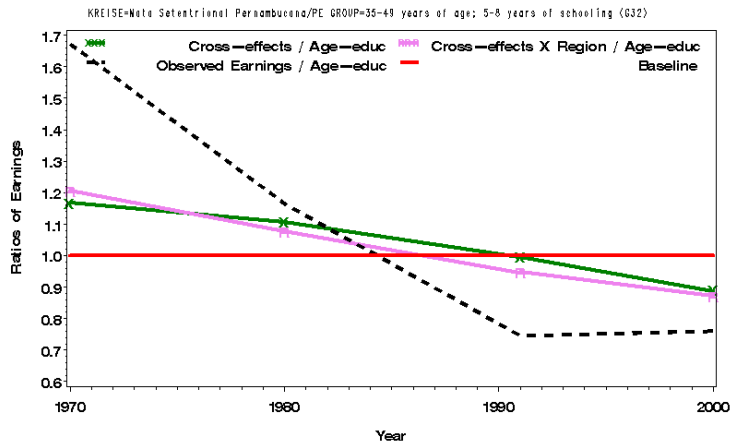

Ilhéus-Itabuna - Bahia Northeast

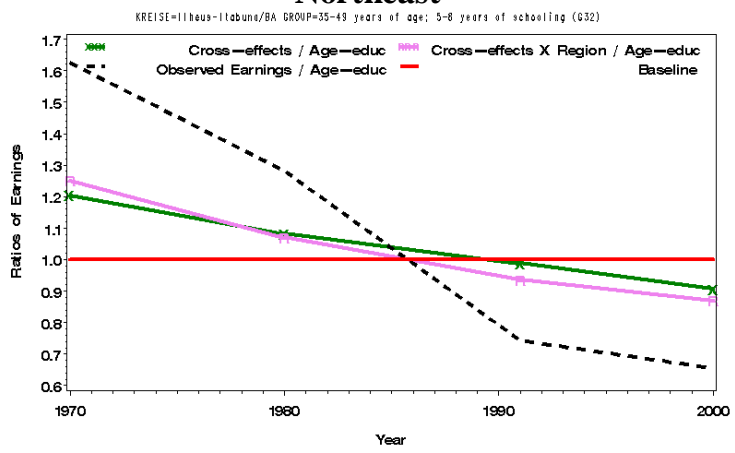

Source: 1970-2000 Brazilian Censuses. 
Figure 5.33. Ratios of Observed Earnings, of Predicted Earnings from Equation (2), and of Predicted Earnings from Equation (2) Including Interactions With Region Indicators, to Predicted Earnings from Table 5.2, Males Ages 35-49 with 58 Years of Education, 1970-2000, Selected Micro-regions (Southeast, South, Center-West).
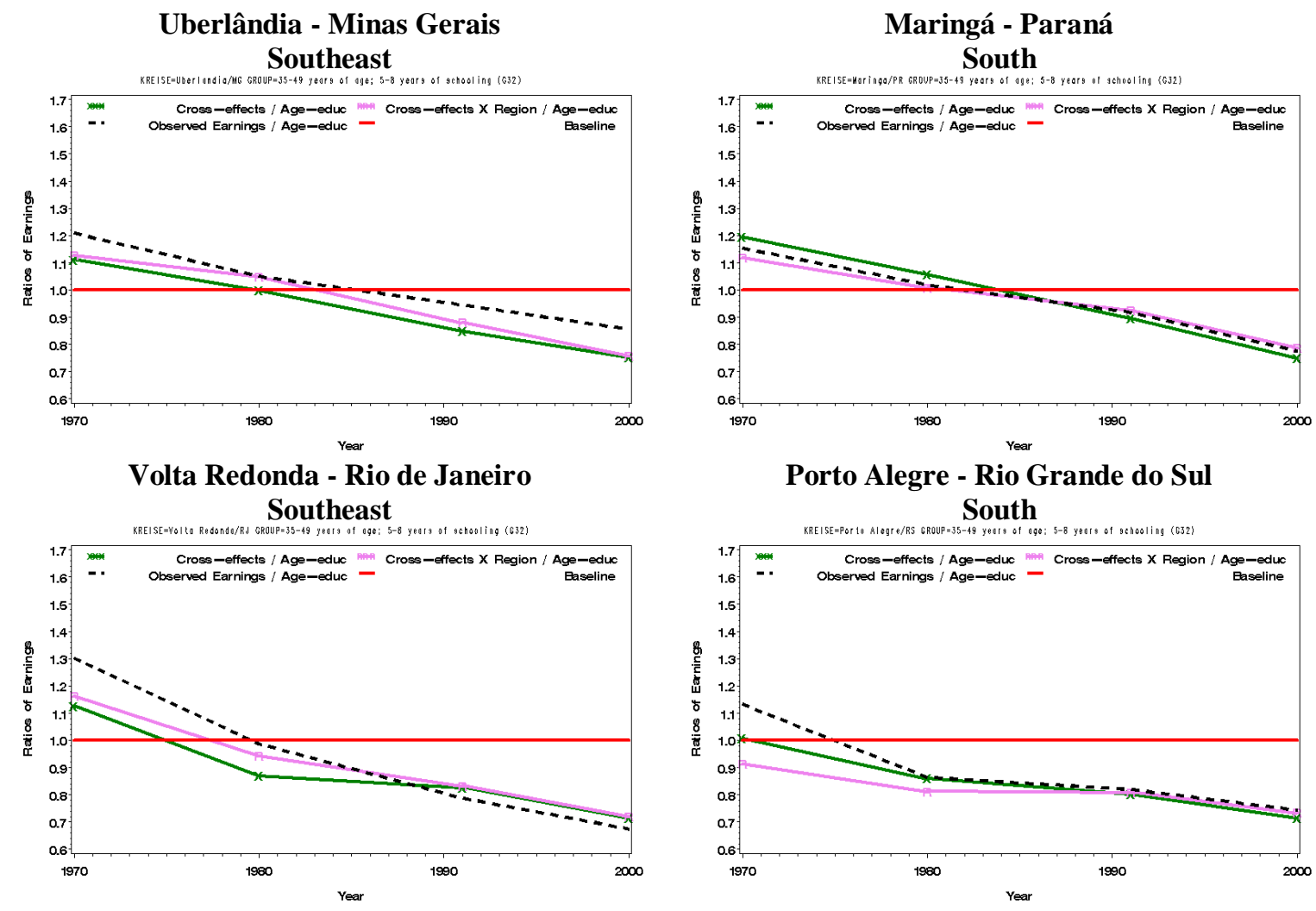

São José do Rio Preto - São Paulo Southeast
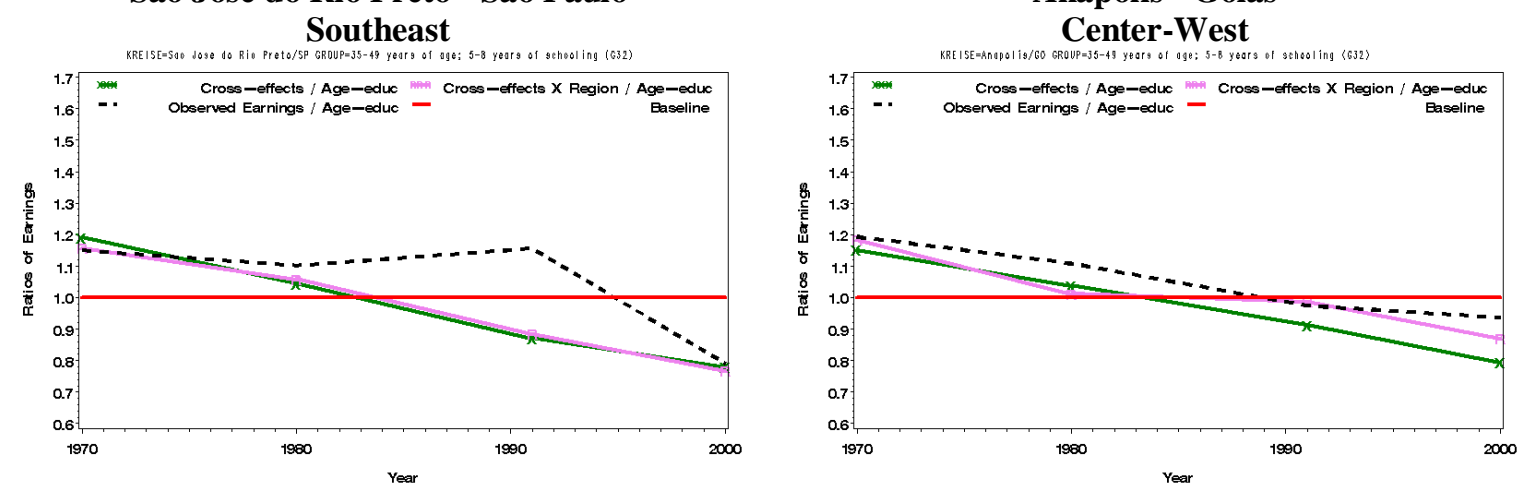

Source: 1970-2000 Brazilian Censuses. 
Figure 5.34. Ratios of Observed Earnings, of Predicted Earnings from Equation (2'), and of Predicted Earnings from Equation (2') Including Interactions With Region Indicators, to Predicted Earnings from Table 5.2, Males Ages 35-49 with 5-8 Years of Education, 1970-2000, Selected Micro-regions (Northeast).

\section{Baixo Parnaíba \& Litoral Piauiense - Piauí} Northeast

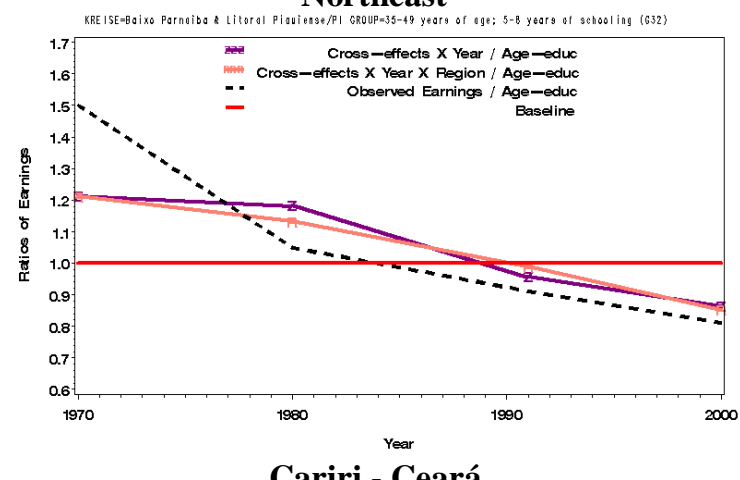

Cariri - Ceará

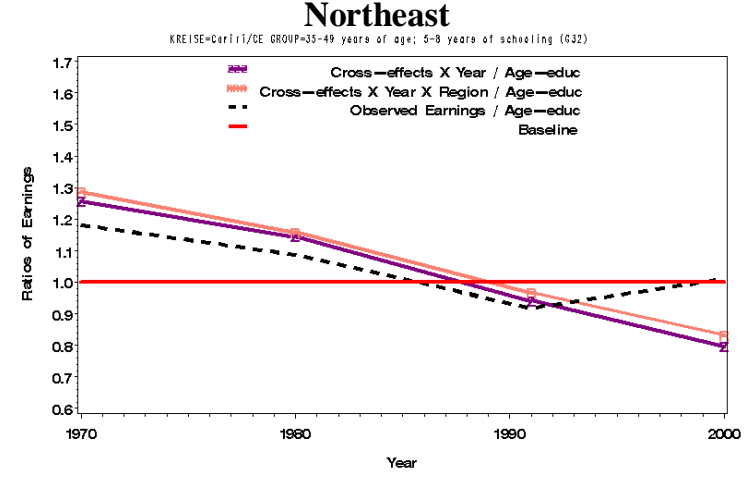

Campina Grande - Paraíba

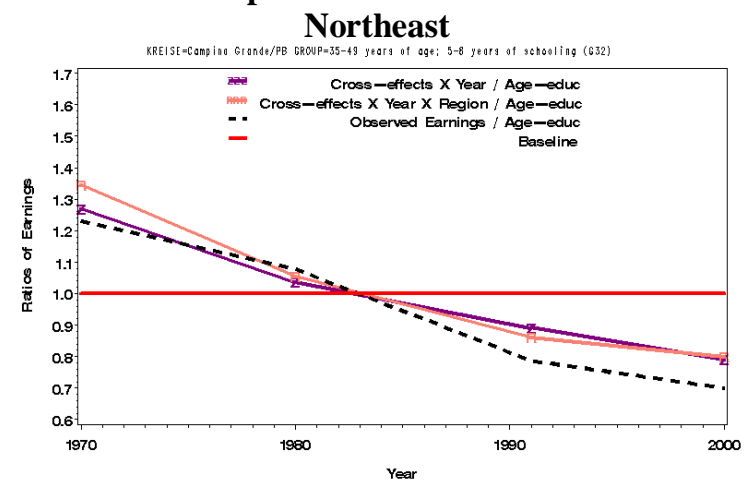

Source: 1970-2000 Brazilian Censuses.

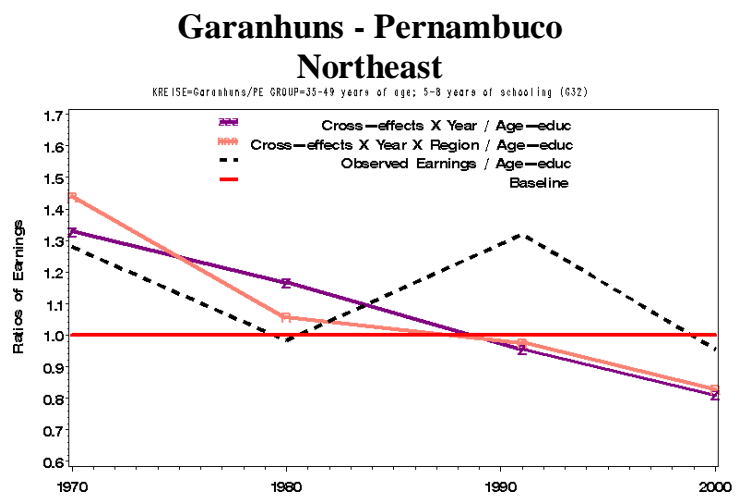

Mata Setentrional - Pernambuco

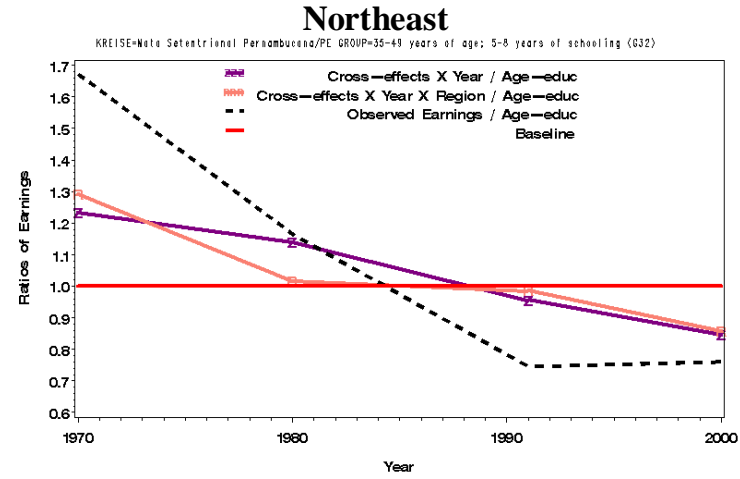

Ilhéus-Itabuna - Bahia

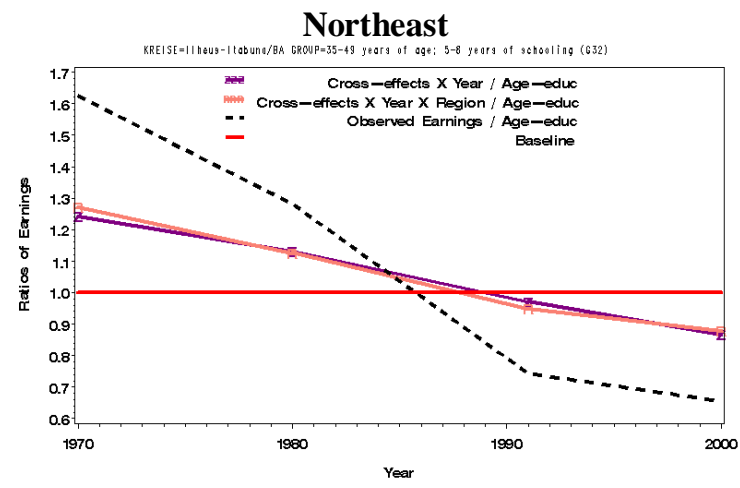


Figure 5.35. Ratios of Observed Earnings, of Predicted Earnings from Equation (2'), and of Predicted Earnings from Equation (2') Including Interactions With Region Indicators, to Predicted Earnings from Table 5.2, Males Ages 35-49 with 5-8 Years of Education, 1970-2000, Selected Micro-regions (Southeast, South, Center-West).
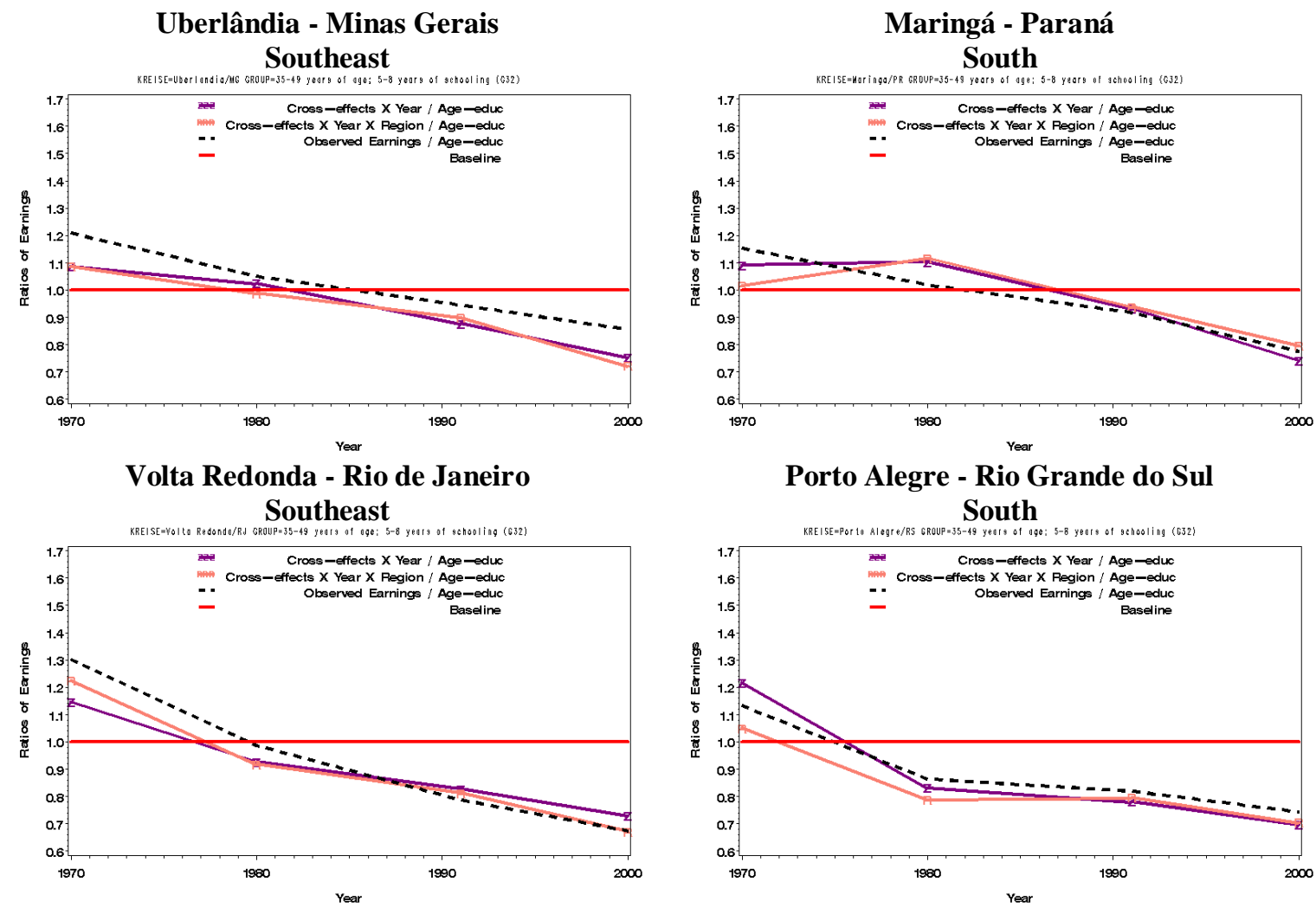

São José do Rio Preto - São Paulo
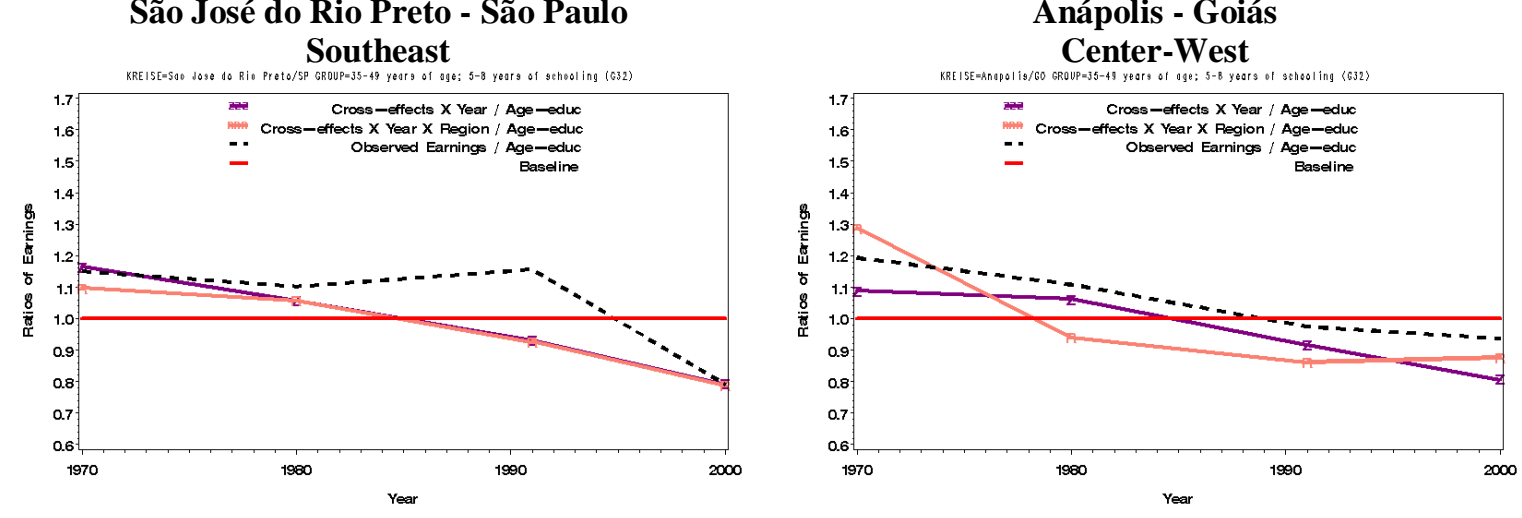

Source: 1970-2000 Brazilian Censuses. 


\section{THE ISSUE OF MICRO-REGION SIZE}

As a strategy to take into account the influence of different population sizes of micro-regions in the prediction of earnings, indicators for size of micro-regions were included in the models, in the same way that region indicators were included above. Microregions were divided into four groups defined by the quartile distribution of the male population receiving earnings for each year, as specified in Chapter 3.

Tables 5.7 and 5.8 illustrate the variation in the male population size across the micro-regions by year and age-education group. Information on the quartiles (25-percent, 50-percent, 75-percent), 10th percentile, 90th percentile, as well as the smallest and largest size of the male population in micro-regions are included in the tables. Only un-weighted cells with at least 25 men in the micro-region by year and age-education group were included in the calculations to generate these tables, in order to have the same criteria used in the regression models.

For age groups 15-24 and 25-34 (Table 5.7), and groups 35-49 and 50-64 (Table 5.8), the statistics for the lowest-education group have been decreasing over time, indicating that this group is becoming scarce in the population. On the other hand, groups with higher education (five to eight years of schooling, and at least nine years of schooling) have an increasing trend in the statistics over time. Even with smaller samples in 1991 and 2000, the number of observations in the better educated groups is bigger than in 1970 and 1980. 
Table 5.7. Variation in Male Population Size Across the Micro-Regions by Year and Age-Education Group, Ages 15-34, 1970-2000.

\begin{tabular}{|c|c|c|c|c|c|c|c|c|}
\hline \multirow[b]{2}{*}{$\begin{array}{l}\text { Age-education } \\
\text { Group }\end{array}$} & \multicolumn{2}{|c|}{1970} & \multicolumn{2}{|c|}{1980} & \multicolumn{2}{|c|}{1991} & \multicolumn{2}{|c|}{2000} \\
\hline & $\begin{array}{c}25 \% \\
\text { (Median) } \\
75 \%\end{array}$ & $\begin{array}{c}\text { (Smallest) } \\
10 \% \\
90 \% \\
\text { (Largest) }\end{array}$ & $\begin{array}{c}25 \% \\
\text { (Median) } \\
75 \%\end{array}$ & $\begin{array}{c}\text { (Smallest) } \\
10 \% \\
90 \% \\
\text { (Largest) }\end{array}$ & $\begin{array}{c}25 \% \\
\text { (Median) } \\
75 \%\end{array}$ & $\begin{array}{c}\text { (Smallest) } \\
10 \% \\
90 \% \\
\text { (Largest) }\end{array}$ & $\begin{array}{c}25 \% \\
\text { (Median) } \\
75 \%\end{array}$ & $\begin{array}{c}\text { (Smallest) } \\
10 \% \\
90 \% \\
\text { (Largest) }\end{array}$ \\
\hline $\begin{array}{c}15-24 \text { years } \\
0-4 \text { years of schooling }\end{array}$ & $\begin{array}{c}817 \\
(1,484.5) \\
2,525\end{array}$ & $\begin{array}{c}(36) \\
418 \\
4,318 \\
(72,362) \\
\end{array}$ & $\begin{array}{c}715 \\
(1,302) \\
2,385\end{array}$ & $\begin{array}{c}(35) \\
366 \\
4,026 \\
(71,885) \\
\end{array}$ & $\begin{array}{c}363 \\
(650) \\
1,146\end{array}$ & $\begin{array}{c}(30) \\
223 \\
1,720 \\
(16,468) \\
\end{array}$ & $\begin{array}{c}215 \\
(397) \\
722\end{array}$ & $\begin{array}{c}(26) \\
132 \\
1,129 \\
(7,894) \\
\end{array}$ \\
\hline $\begin{array}{c}15-24 \text { years } \\
5-8 \text { years of schooling }\end{array}$ & $\begin{array}{c}57.5 \\
(131) \\
317\end{array}$ & $\begin{array}{c}(25) \\
34 \\
728 \\
(24,825) \\
\end{array}$ & $\begin{array}{c}115 \\
(317) \\
727\end{array}$ & $\begin{array}{c}(25) \\
57 \\
1,866 \\
(70,745) \\
\end{array}$ & $\begin{array}{c}125 \\
(296) \\
618\end{array}$ & $\begin{array}{c}(25) \\
62 \\
1,398.5 \\
(32,205) \\
\end{array}$ & $\begin{array}{c}182 \\
(383.5) \\
706\end{array}$ & $\begin{array}{c}(27) \\
87 \\
1,405 \\
(20,514) \\
\end{array}$ \\
\hline $\begin{array}{c}15-24 \text { years } \\
9+\text { years of schooling }\end{array}$ & $\begin{array}{c}48.5 \\
(89) \\
217.5\end{array}$ & $\begin{array}{c}(25) \\
31 \\
492.5 \\
(13,867)\end{array}$ & $\begin{array}{c}74 \\
(177) \\
444\end{array}$ & $\begin{array}{c}(25) \\
38 \\
1,256 \\
(42,891) \\
\end{array}$ & $\begin{array}{c}62 \\
(138) \\
288\end{array}$ & $\begin{array}{c}(25) \\
37 \\
684.5 \\
(20,967) \\
\end{array}$ & $\begin{array}{c}109.5 \\
(269.5) \\
585\end{array}$ & $\begin{array}{c}(26) \\
55.5 \\
1,268 \\
(35,327)\end{array}$ \\
\hline $\begin{array}{c}25-34 \text { years } \\
0-4 \text { years of schooling }\end{array}$ & $\begin{array}{c}840 \\
(1,496.5) \\
4,460\end{array}$ & $\begin{array}{c}(35) \\
440 \\
4,460 \\
(88,004) \\
\end{array}$ & $\begin{array}{c}750 \\
(1,371) \\
2,457\end{array}$ & $\begin{array}{c}(60) \\
389 \\
4,554 \\
(104,801) \\
\end{array}$ & $\begin{array}{c}430 \\
(744) \\
1,277\end{array}$ & $\begin{array}{c}(44) \\
269 \\
1,993 \\
(27,794) \\
\end{array}$ & $\begin{array}{c}331 \\
(582) \\
1,001\end{array}$ & $\begin{array}{c}(25) \\
199 \\
1,634 \\
(17,777) \\
\end{array}$ \\
\hline $\begin{array}{c}25-34 \text { years } \\
5-8 \text { years of schooling }\end{array}$ & $\begin{array}{l}46 \\
(93) \\
203\end{array}$ & $\begin{array}{c}(25) \\
34 \\
514 \\
(21,530) \\
\end{array}$ & $\begin{array}{c}73 \\
(178) \\
403.5\end{array}$ & $\begin{array}{c}(25) \\
41 \\
1,097 \\
(42,963) \\
\end{array}$ & $\begin{array}{c}100 \\
(220) \\
495\end{array}$ & $\begin{array}{c}(26) \\
50 \\
1,185 \\
(26,065) \\
\end{array}$ & $\begin{array}{c}163 \\
(332) \\
676\end{array}$ & $\begin{array}{c}(29) \\
74 \\
1,440 \\
(27,369) \\
\end{array}$ \\
\hline $\begin{array}{c}25-34 \text { years } \\
9+\text { years of schooling }\end{array}$ & $\begin{array}{c}31 \\
(102) \\
584\end{array}$ & $\begin{array}{c}(25) \\
31 \\
584 \\
(21,181) \\
\end{array}$ & $\begin{array}{c}75.5 \\
(186.5) \\
466\end{array}$ & $\begin{array}{c}(25) \\
43 \\
1,348 \\
(55,992) \\
\end{array}$ & $\begin{array}{c}86 \\
(198) \\
423\end{array}$ & $\begin{array}{c}(25) \\
47 \\
1,125 \\
(35,948) \\
\end{array}$ & $\begin{array}{c}120 \\
(255) \\
583\end{array}$ & $\begin{array}{c}(25) \\
61 \\
1,447 \\
(43,571) \\
\end{array}$ \\
\hline $\begin{array}{c}\text { Total for all } 12 \\
\text { age-education groups }\end{array}$ & $\begin{array}{c}87 \\
(434.5) \\
1,519\end{array}$ & $\begin{array}{c}(\mathbf{2 5}) \\
39 \\
2,970 \\
(\mathbf{1 0 2 , 5 7 1 )}\end{array}$ & $\begin{array}{c}107 \\
(410) \\
1,301\end{array}$ & $\begin{array}{c}(25) \\
47 \\
2,746 \\
(104,819)\end{array}$ & $\begin{array}{c}105 \\
(329) \\
806\end{array}$ & $\begin{array}{c}(25) \\
48 \\
1,603 \\
(43,761) \\
\end{array}$ & $\begin{array}{c}139 \\
(347) \\
756\end{array}$ & $\begin{array}{c}(25) \\
61 \\
1,496 \\
(46,068) \\
\end{array}$ \\
\hline
\end{tabular}

${ }^{+}$Only un-weighted cells with at least 25 men in the micro-region by year and age-education group were included in these calculations.

Source: 1970-2000 Brazilian Censuses. 
Table 5.8. Variation in Male Population Size Across the Micro-Regions by Year and Age-Education Group, Ages 35-64, 1970-2000.

\begin{tabular}{|c|c|c|c|c|c|c|c|c|}
\hline \multirow[b]{2}{*}{$\begin{array}{l}\text { Age-education } \\
\text { Group }\end{array}$} & \multicolumn{2}{|c|}{1970} & \multicolumn{2}{|c|}{1980} & \multicolumn{2}{|c|}{1991} & \multicolumn{2}{|c|}{2000} \\
\hline & $\begin{array}{c}25 \% \\
\text { (Median) } \\
75 \%\end{array}$ & $\begin{array}{c}\text { (Smallest) } \\
10 \% \\
90 \% \\
\text { (Largest) }\end{array}$ & $\begin{array}{c}25 \% \\
\text { (Median) } \\
75 \%\end{array}$ & $\begin{array}{c}\text { (Smallest) } \\
10 \% \\
90 \% \\
\text { (Largest) }\end{array}$ & $\begin{array}{c}25 \% \\
\text { (Median) } \\
75 \%\end{array}$ & $\begin{array}{c}\text { (Smallest) } \\
10 \% \\
90 \% \\
\text { (Largest) }\end{array}$ & $\begin{array}{c}25 \% \\
\text { (Median) } \\
75 \%\end{array}$ & $\begin{array}{c}\text { (Smallest) } \\
10 \% \\
90 \% \\
\text { (Largest) }\end{array}$ \\
\hline $\begin{array}{c}35-49 \text { years } \\
0-4 \text { years of schooling }\end{array}$ & $\begin{array}{c}972 \\
(1,831.5) \\
3,088\end{array}$ & $\begin{array}{c}(55) \\
502 \\
5,405 \\
(102,571) \\
\end{array}$ & $\begin{array}{c}814 \\
(1,535.5) \\
2,741\end{array}$ & $\begin{array}{c}(33) \\
394 \\
5,032 \\
(104,819) \\
\end{array}$ & $\begin{array}{c}588 \\
(1,026.5) \\
1,755\end{array}$ & $\begin{array}{c}(39) \\
356 \\
2,811 \\
(43,761) \\
\end{array}$ & $\begin{array}{c}488 \\
(883) \\
1,534\end{array}$ & $\begin{array}{c}(41) \\
282 \\
2,646 \\
(28,386)\end{array}$ \\
\hline $\begin{array}{c}35-49 \text { years } \\
5-8 \text { years of schooling }\end{array}$ & $\begin{array}{c}41 \\
(84) \\
179\end{array}$ & $\begin{array}{c}(25) \\
32 \\
455 \\
(22,975) \\
\end{array}$ & $\begin{array}{c}55 \\
(118) \\
275\end{array}$ & $\begin{array}{c}(25) \\
36 \\
735 \\
(30,926) \\
\end{array}$ & $\begin{array}{c}57 \\
(129) \\
285\end{array}$ & $\begin{array}{c}(25) \\
37 \\
663 \\
(17,364) \\
\end{array}$ & $\begin{array}{c}120 \\
(279) \\
599\end{array}$ & $\begin{array}{c}(25) \\
62 \\
1,290 \\
(26,742) \\
\end{array}$ \\
\hline $\begin{array}{c}35-49 \text { years } \\
9+\text { years of schooling }\end{array}$ & $\begin{array}{l}48 \\
(93) \\
221\end{array}$ & $\begin{array}{c}(25) \\
30 \\
510 \\
(22,399)\end{array}$ & $\begin{array}{c}54 \\
(124.5) \\
306\end{array}$ & $\begin{array}{c}(25) \\
33 \\
937.5 \\
(38,416)\end{array}$ & $\begin{array}{c}64 \\
(148) \\
349\end{array}$ & $\begin{array}{c}(25) \\
39 \\
926 \\
(30,008)\end{array}$ & $\begin{array}{c}107 \\
(250) \\
602\end{array}$ & $\begin{array}{c}(26) \\
54 \\
1,454 \\
(46,068)\end{array}$ \\
\hline $\begin{array}{c}50-64 \text { years } \\
0-4 \text { years of schooling }\end{array}$ & $\begin{array}{c}573 \\
(1,026.5) \\
1,763\end{array}$ & $\begin{array}{c}(33) \\
293 \\
2,861 \\
(53,336) \\
\end{array}$ & $\begin{array}{c}475 \\
(861) \\
1,555\end{array}$ & $\begin{array}{c}(47) \\
259 \\
2,661 \\
(45,990) \\
\end{array}$ & $\begin{array}{c}332 \\
(599) \\
1,002\end{array}$ & $\begin{array}{c}(25) \\
203 \\
1,661 \\
(20,505) \\
\end{array}$ & $\begin{array}{l}301.5 \\
(553) \\
933.5\end{array}$ & $\begin{array}{c}(37) \\
179 \\
1,633 \\
(16,911) \\
\end{array}$ \\
\hline $\begin{array}{c}50-64 \text { years } \\
5-8 \text { years of schooling }\end{array}$ & $\begin{array}{c}35 \\
(53) \\
121\end{array}$ & $\begin{array}{c}(25) \\
28 \\
284 \\
(10,222) \\
\end{array}$ & $\begin{array}{c}39 \\
(62.5) \\
138\end{array}$ & $\begin{array}{c}(25) \\
28 \\
300 \\
(11,269) \\
\end{array}$ & $\begin{array}{c}35 \\
(54) \\
98\end{array}$ & $\begin{array}{c}(25) \\
28 \\
210 \\
(4,708) \\
\end{array}$ & $\begin{array}{c}46 \\
(75) \\
156\end{array}$ & $\begin{array}{c}(25) \\
33 \\
319 \\
(6,884) \\
\end{array}$ \\
\hline $\begin{array}{c}50-64 \text { years } \\
9+\text { years of schooling }\end{array}$ & $\begin{array}{c}36 \\
(60) \\
135\end{array}$ & $\begin{array}{c}(25) \\
29 \\
343 \\
(10,278) \\
\end{array}$ & $\begin{array}{c}44 \\
(71) \\
182\end{array}$ & $\begin{array}{c}(25) \\
32 \\
438 \\
(14,764) \\
\end{array}$ & $\begin{array}{c}39 \\
(64) \\
145\end{array}$ & $\begin{array}{c}(25) \\
30 \\
335 \\
(8,650) \\
\end{array}$ & $\begin{array}{c}50 \\
(99.5) \\
197\end{array}$ & $\begin{array}{c}(25) \\
32 \\
585 \\
(14,147) \\
\end{array}$ \\
\hline $\begin{array}{c}\text { Total for all } 12 \\
\text { age-education groups }\end{array}$ & $\begin{array}{c}87 \\
(434.5) \\
1,519\end{array}$ & $\begin{array}{c}(\mathbf{2 5}) \\
39 \\
2,970 \\
(\mathbf{1 0 2 , 5 7 1 )}\end{array}$ & $\begin{array}{c}107 \\
(410) \\
1,301\end{array}$ & $\begin{array}{c}(\mathbf{2 5}) \\
47 \\
2,746 \\
(\mathbf{1 0 4 , 8 1 9 )}\end{array}$ & $\begin{array}{c}105 \\
(329) \\
806\end{array}$ & $\begin{array}{c}(25) \\
48 \\
1,603 \\
(43,761) \\
\end{array}$ & $\begin{array}{c}139 \\
(347) \\
756\end{array}$ & $\begin{array}{c}(25) \\
61 \\
1,496 \\
(46,068) \\
\end{array}$ \\
\hline
\end{tabular}

${ }^{+}$Only un-weighted cells with at least 25 men in the micro-region by year and age-education group were included in these calculations.

Source: 1970-2000 Brazilian Censuses.

Results of estimates in Equations (1), (1'), (2) and (2'), including interactions of proportions of males in age-education groups with indicators of population size of microregions, are illustrated in Figures 5.36 to 5.43. Tabular format of these new estimates are 
not shown, because of the large amount of coefficients generated. As anticipated, results suggest that the bigger the micro-region, the greater the earnings. However, the new estimates suggest that predicted earnings do not change significantly from original Equations (1), (1'), (2) and (2') after the inclusion of interactions with micro-region size. This finding might be a sign that original estimates presented above fit the observed data well, even not controlling for population size of micro-regions. These re-estimates indicate that the functions are not heterothetic, thus different population sizes of micro-regions do not alter the impact of the age-education-group proportions on earnings. This result is in agreement with the assumption of homotheticity. 
Figure 5.36. Ratios of Observed Earnings, of Predicted Earnings from Equation (1), and of Predicted Earnings from Equation (1) Including Interactions With Microregion Size, to Predicted Earnings from Table 5.2, Males Ages 35-49 with 5-8 Years of Education, 1970-2000, Selected Micro-regions (Northeast).
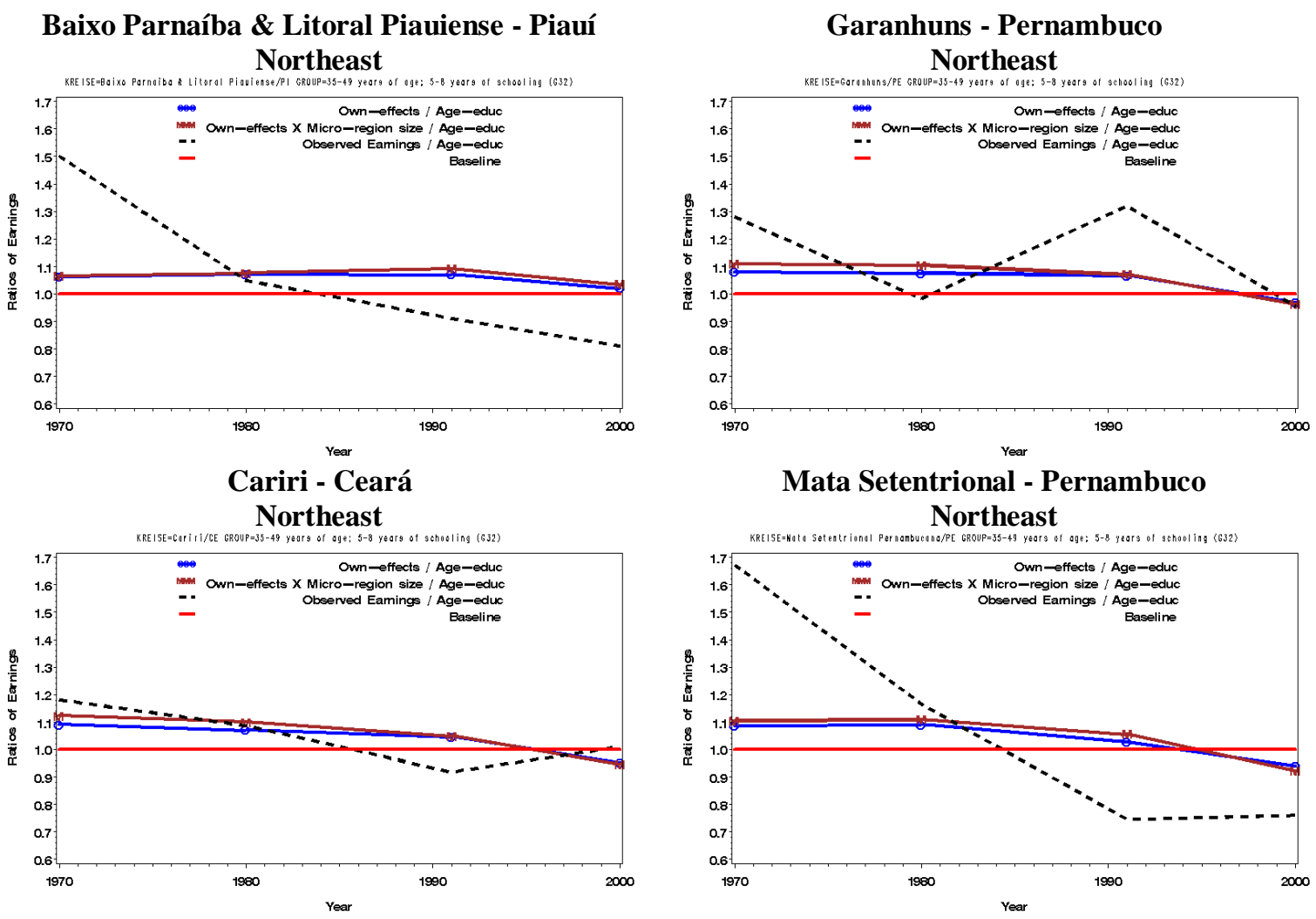

Mata Setentrional - Pernambuco

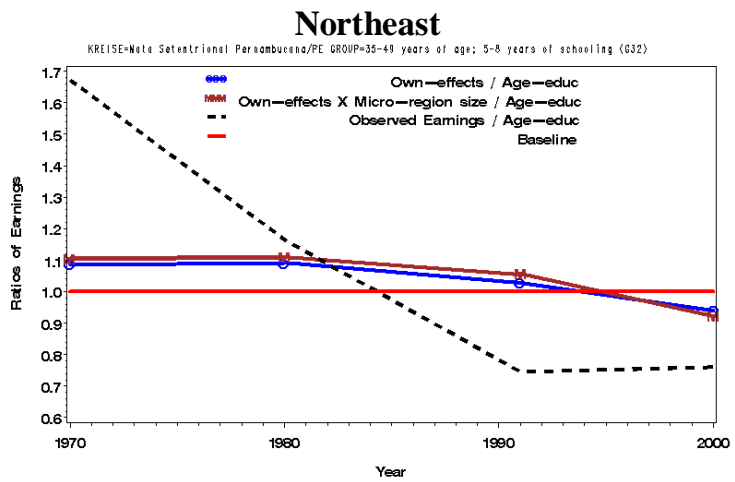

Campina Grande - Paraíba

Northeast

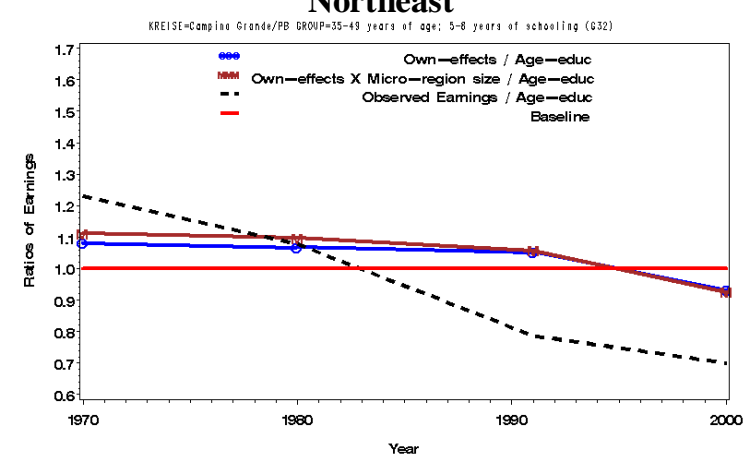

Ilhéus-Itabuna - Bahia Northeast

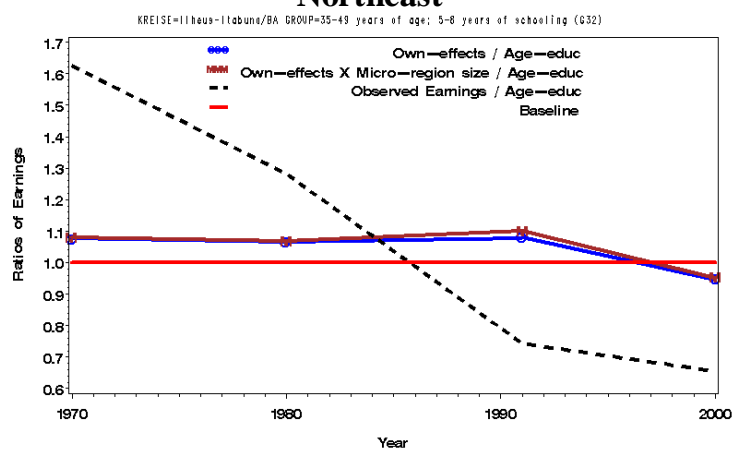

Source: 1970-2000 Brazilian Censuses. 
Figure 5.37. Ratios of Observed Earnings, of Predicted Earnings from Equation (1), and of Predicted Earnings from Equation (1) Including Interactions With Microregion Size, to Predicted Earnings from Table 5.2, Males Ages 35-49 with 5-8 Years of Education, 1970-2000, Selected Micro-regions (Southeast, South, Center-West).
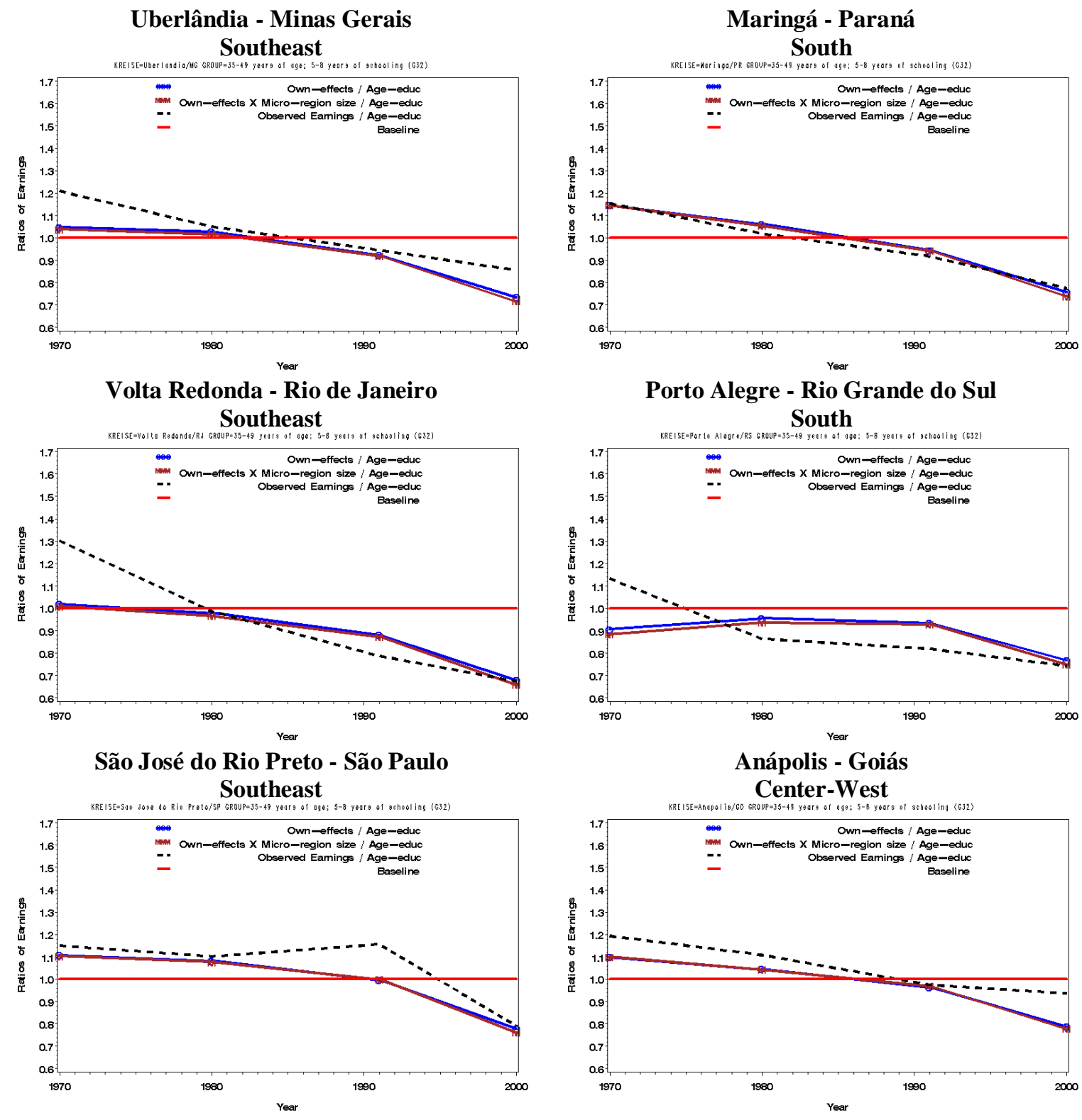

Source: 1970-2000 Brazilian Censuses. 
Figure 5.38. Ratios of Observed Earnings, of Predicted Earnings from Equation (1'), and of Predicted Earnings from Equation (1') Including Interactions With Micro-region Size, to Predicted Earnings from Table 5.2, Males Ages 35-49 with 5-8 Years of Education, 1970-2000, Selected Micro-regions (Northeast).

\section{Baixo Parnaíba \& Litoral Piauiense - Piauí} Northeast
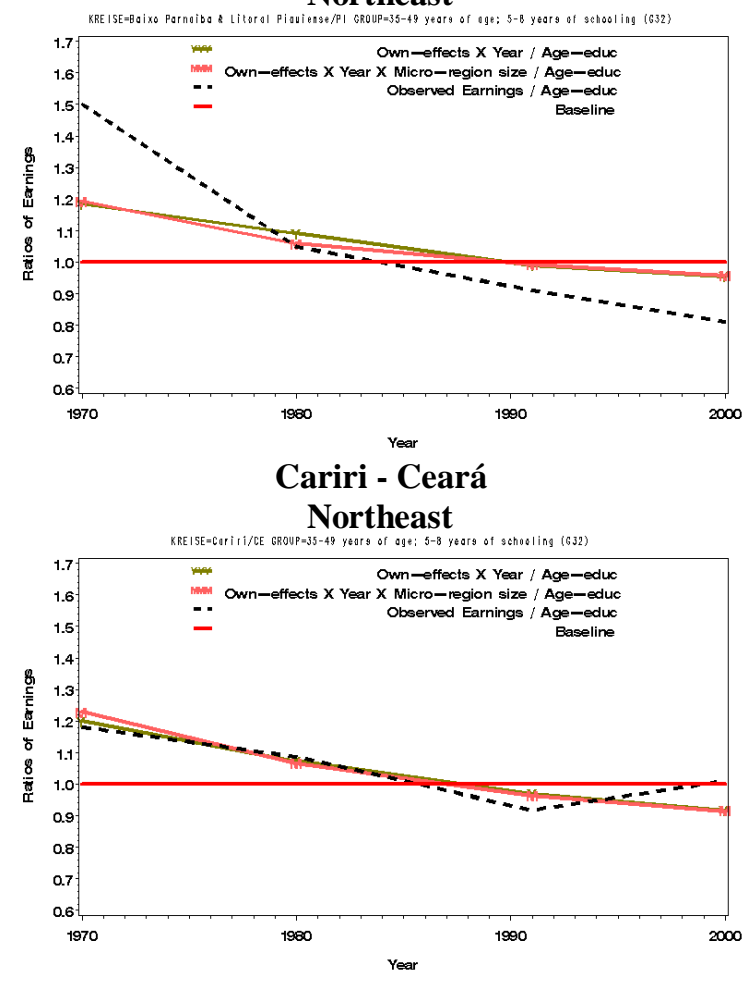

Campina Grande - Paraíba

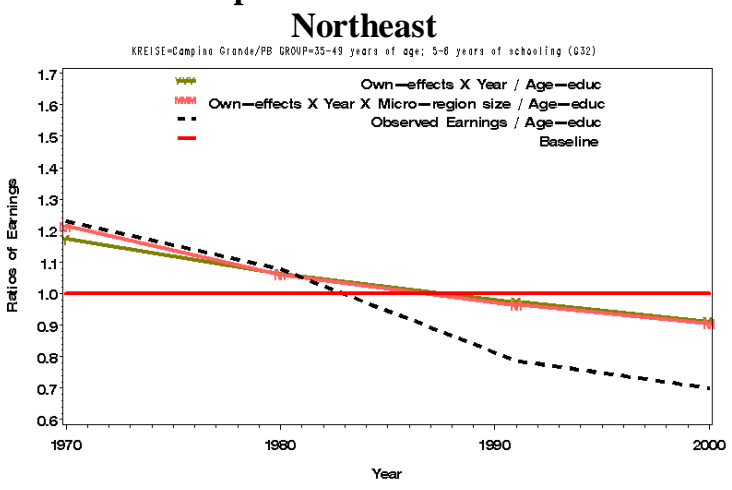

Source: 1970-2000 Brazilian Censuses.

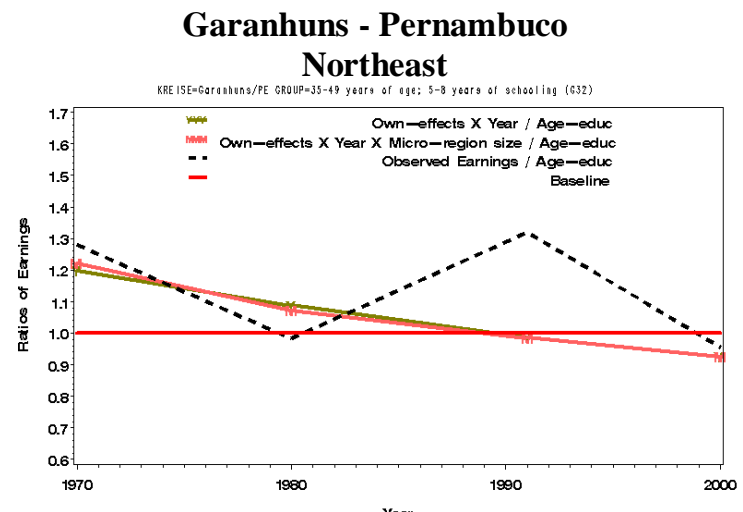

Mata Setentrional - Pernambuco Northeast

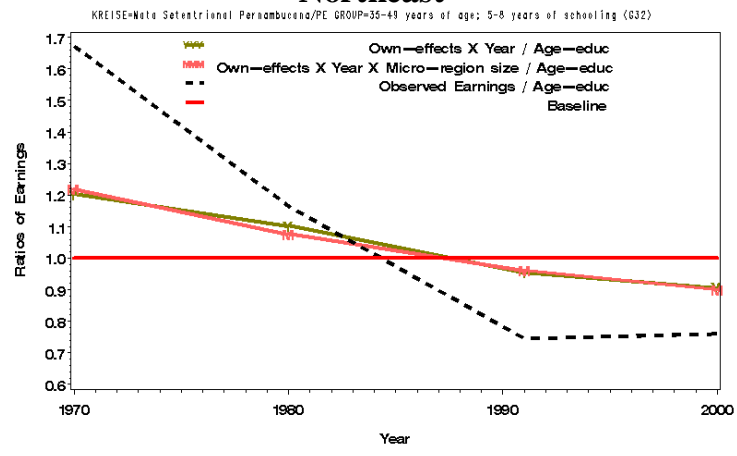

Ilhéus-Itabuna - Bahia

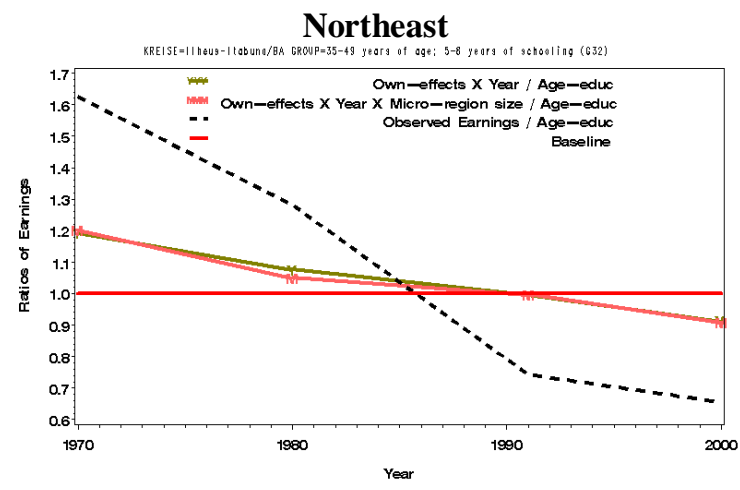


Figure 5.39. Ratios of Observed Earnings, of Predicted Earnings from Equation (1'), and of Predicted Earnings from Equation (1') Including Interactions With Micro-region Size, to Predicted Earnings from Table 5.2, Males Ages 35-49 with 5-8 Years of Education, 1970-2000, Selected Micro-regions (Southeast, South, Center-West).
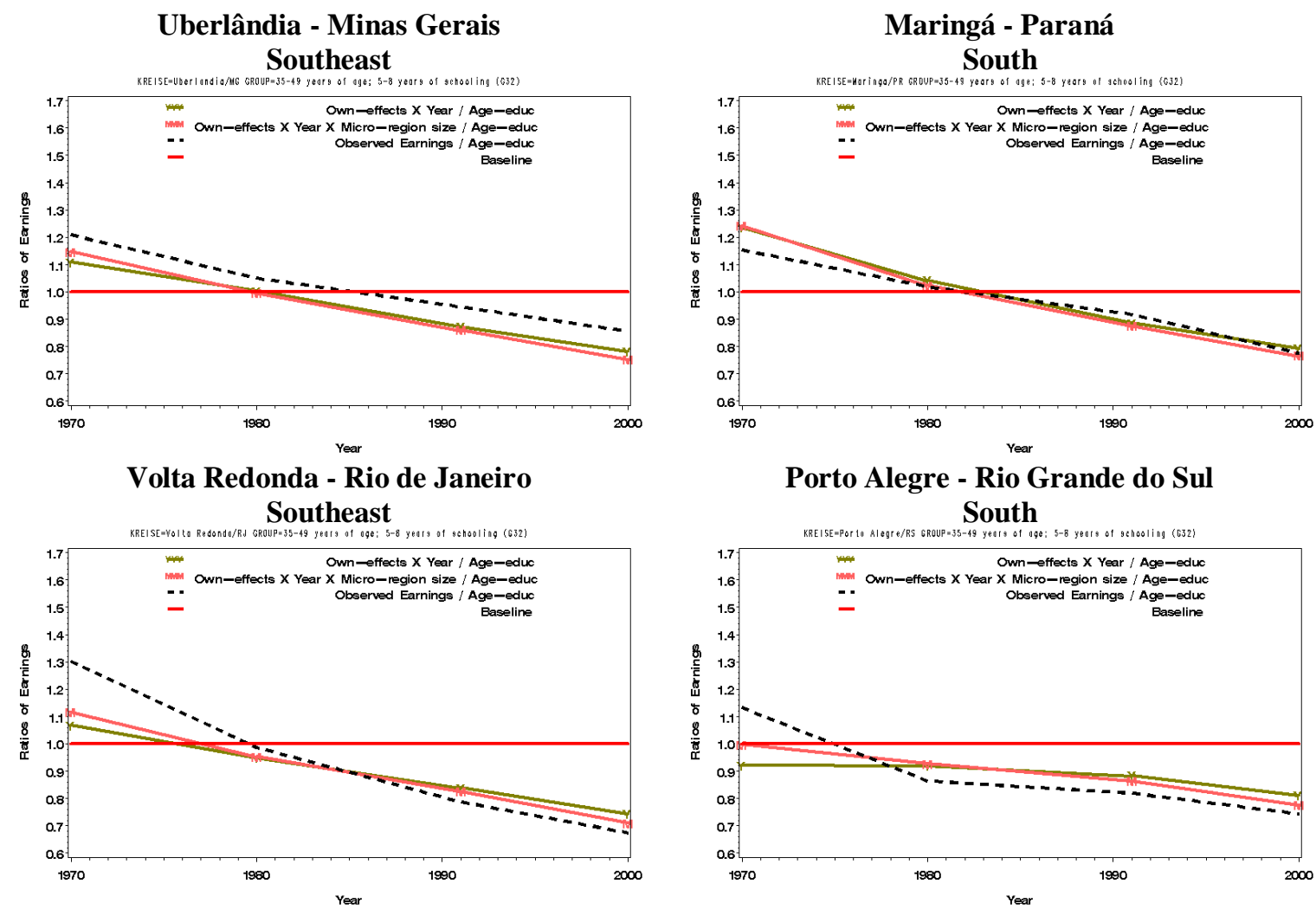

São José do Rio Preto - São Paulo Southeast
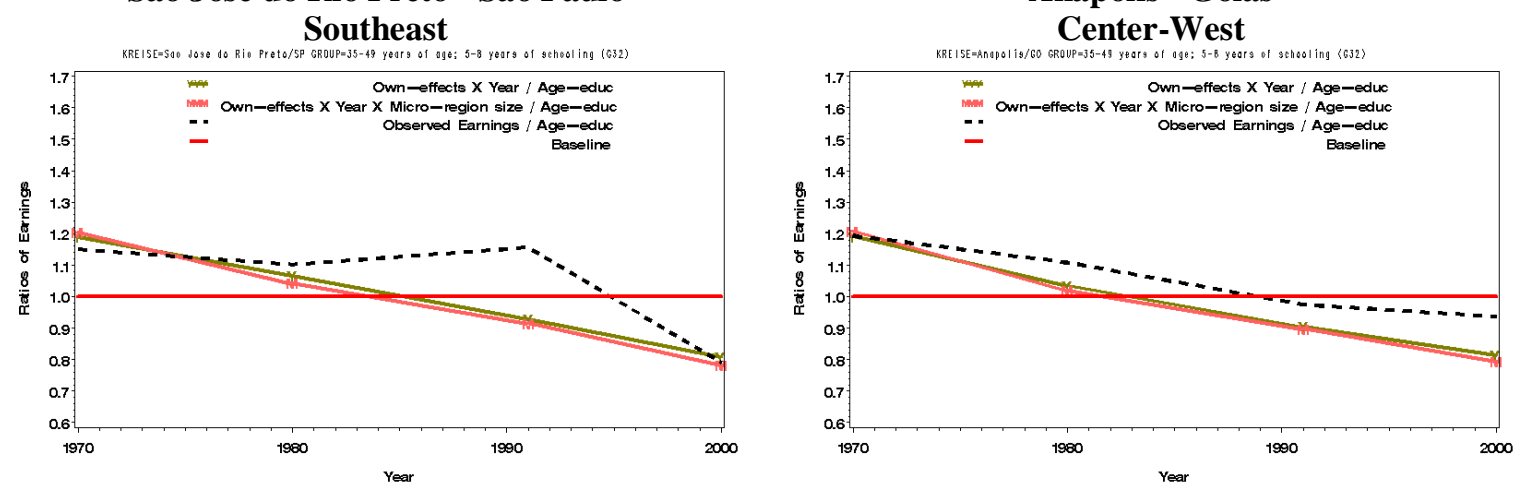

Source: 1970-2000 Brazilian Censuses. 
Figure 5.40. Ratios of Observed Earnings, of Predicted Earnings from Equation (2), and of Predicted Earnings from Equation (2) Including Interactions With Microregion Size, to Predicted Earnings from Table 5.2, Males Ages 35-49 with 5-8 Years of Education, 1970-2000, Selected Micro-regions (Northeast).
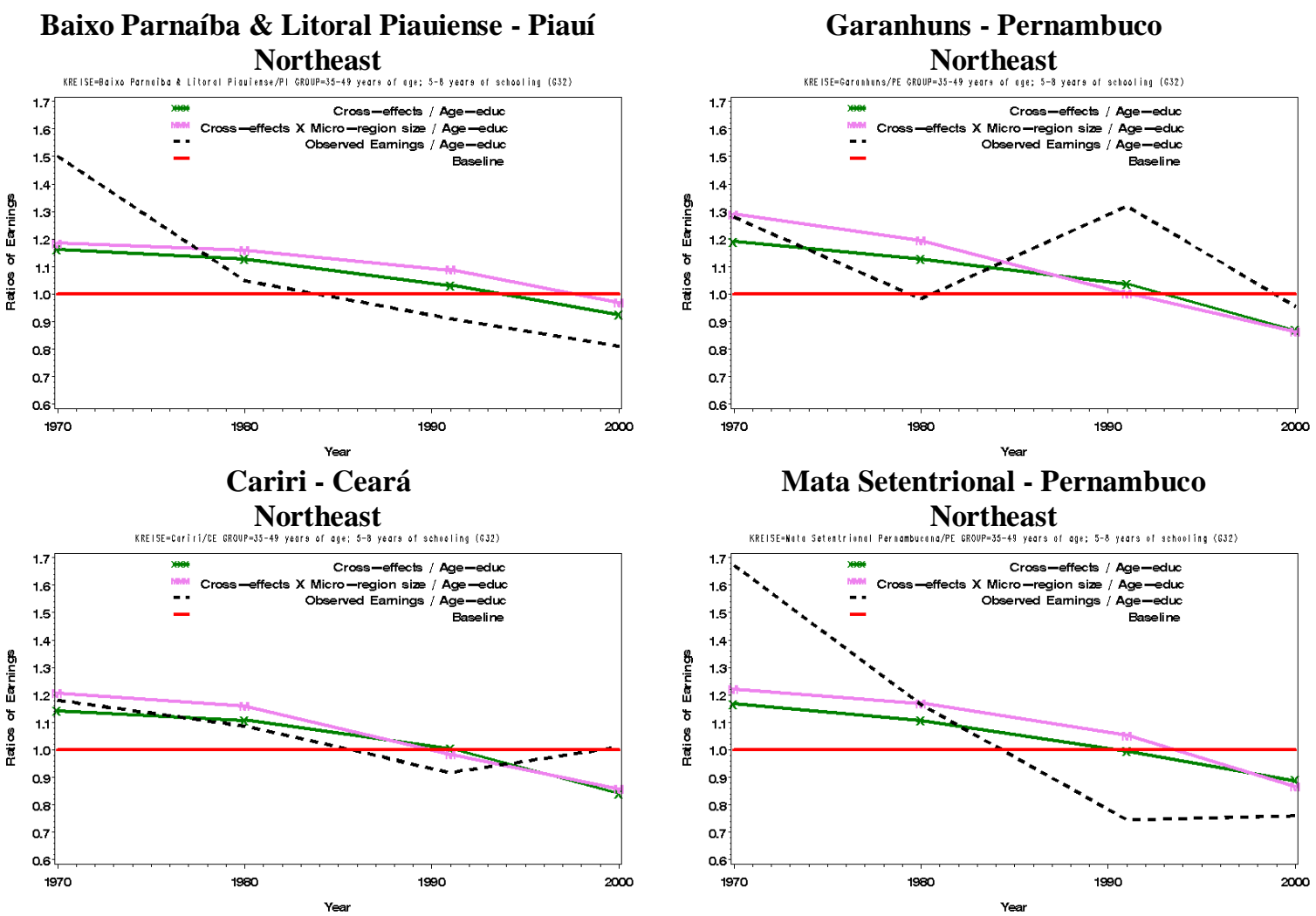

Mata Setentrional - Pernambuco

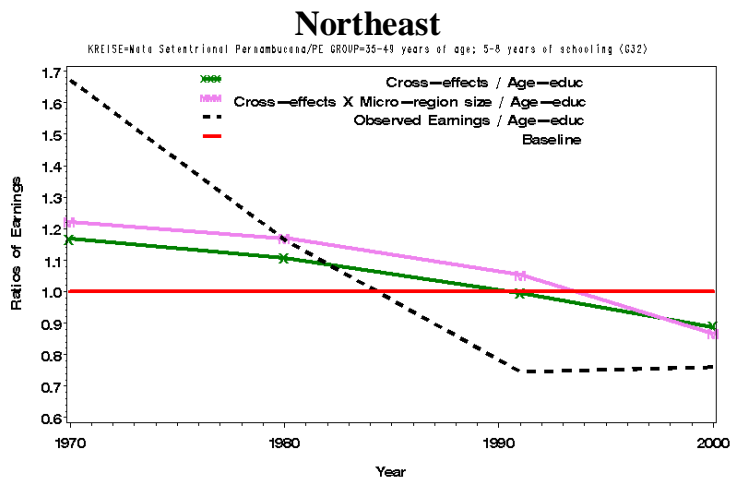

Campina Grande - Paraíba

Northeast

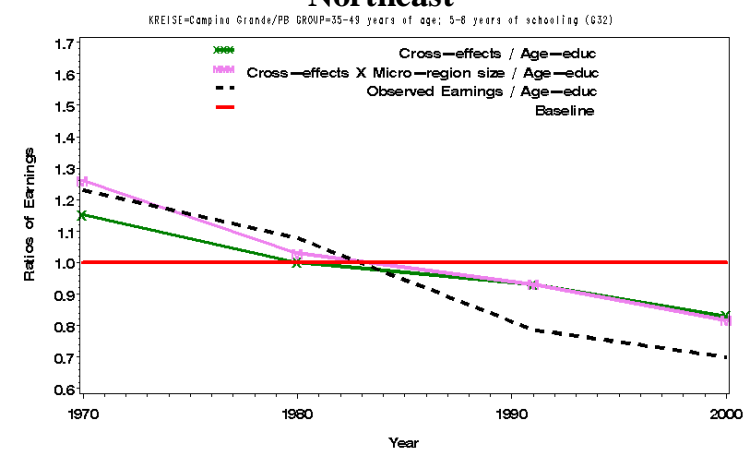

Ilhéus-Itabuna - Bahia Northeast

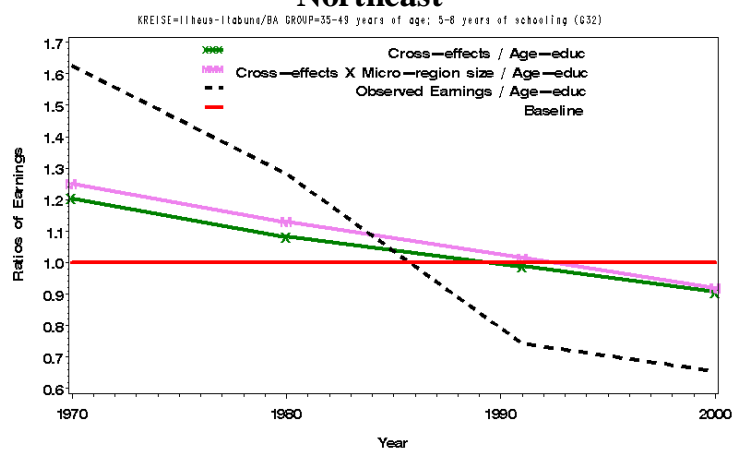

Source: 1970-2000 Brazilian Censuses. 
Figure 5.41. Ratios of Observed Earnings, of Predicted Earnings from Equation (2), and of Predicted Earnings from Equation (2) Including Interactions With Microregion Size, to Predicted Earnings from Table 5.2, Males Ages 35-49 with 5-8 Years of Education, 1970-2000, Selected Micro-regions (Southeast, South, Center-West).
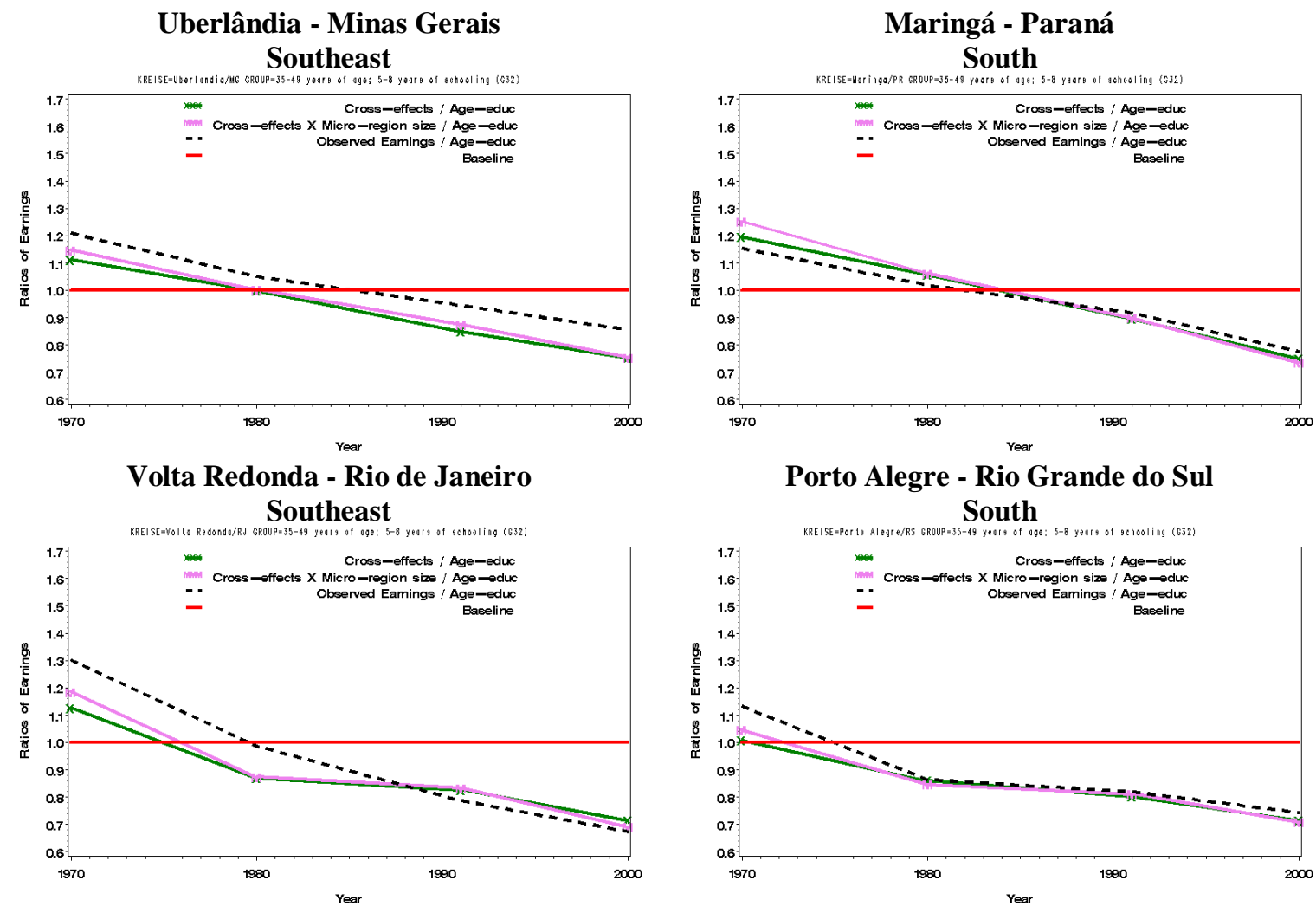

São José do Rio Preto - São Paulo
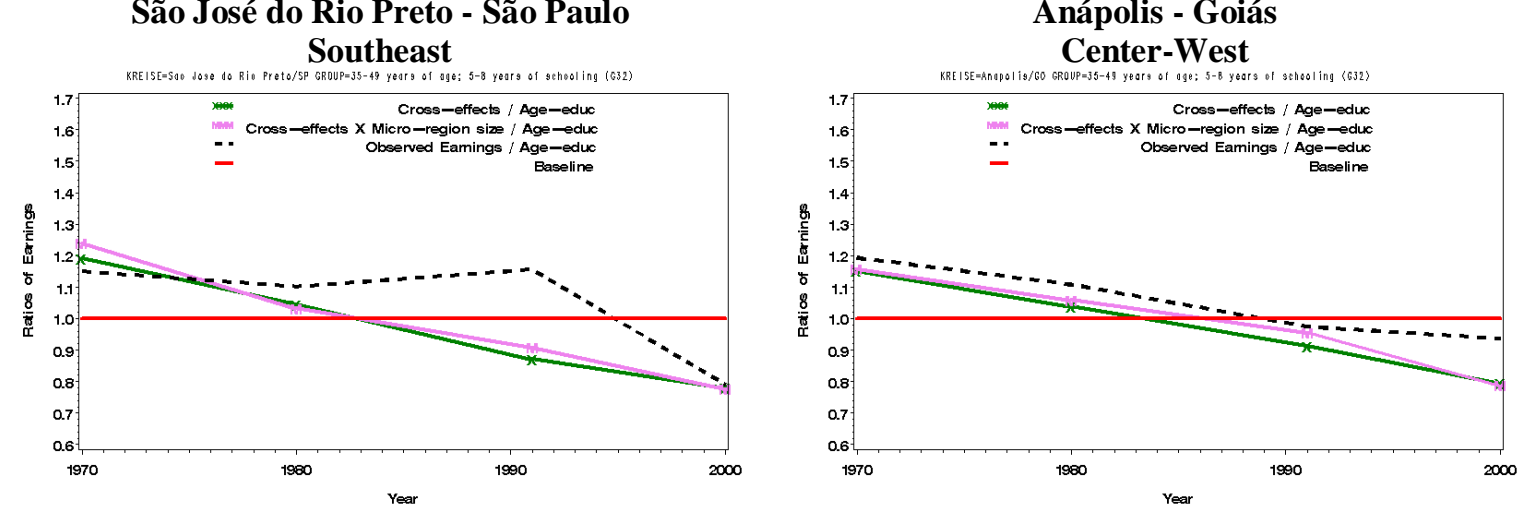

Source: 1970-2000 Brazilian Censuses. 
Figure 5.42. Ratios of Observed Earnings, of Predicted Earnings from Equation (2'), and of Predicted Earnings from Equation (2') Including Interactions With Micro-region Size, to Predicted Earnings from Table 5.2, Males Ages 35-49 with 5-8 Years of Education, 1970-2000, Selected Micro-regions (Northeast).

\section{Baixo Parnaíba \& Litoral Piauiense - Piauí \\ Northeast}

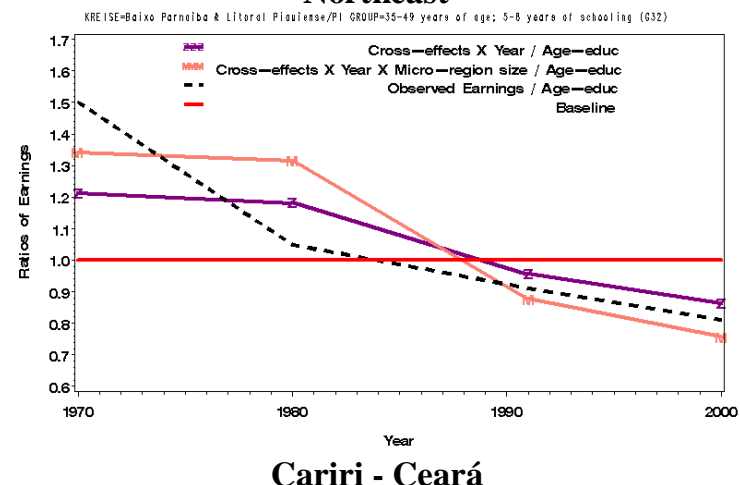

Cariri - Ceará

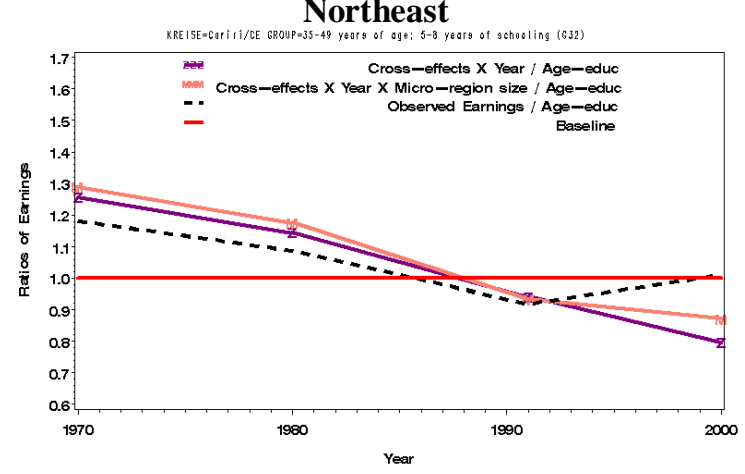

Campina Grande - Paraíba Northeast

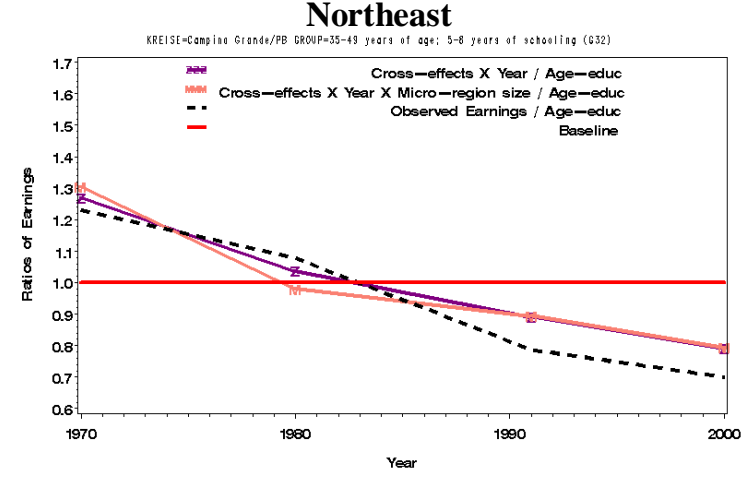

Source: 1970-2000 Brazilian Censuses.

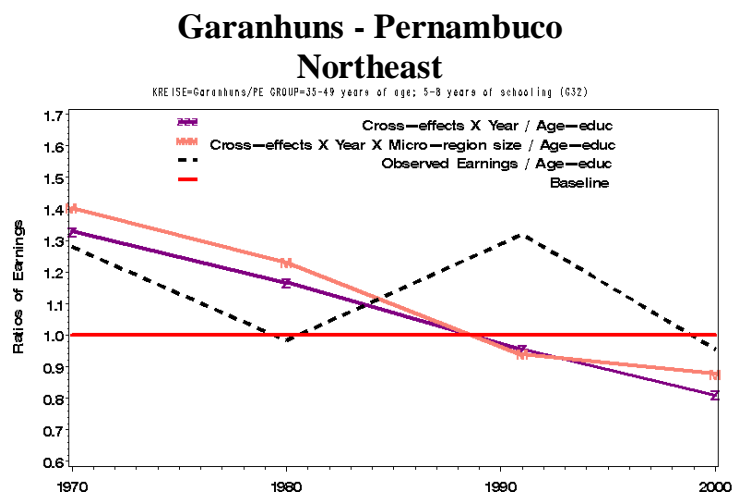

Mata Setentrional - Pernambuco Northeast

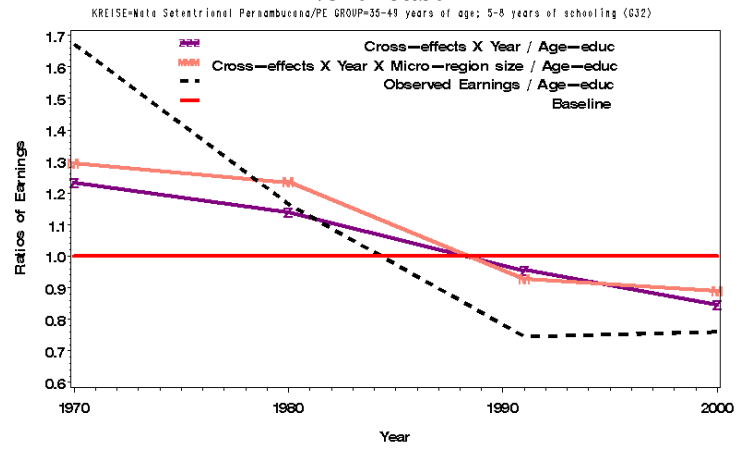

Ilhéus-Itabuna - Bahia

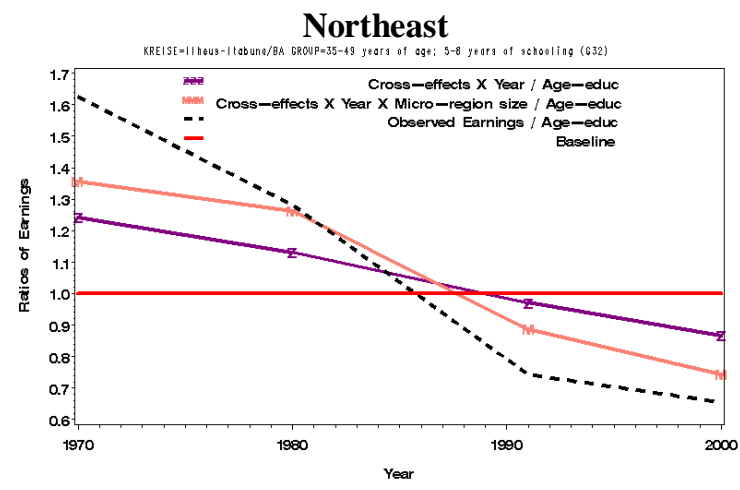


Figure 5.43. Ratios of Observed Earnings, of Predicted Earnings from Equation (2'), and of Predicted Earnings from Equation (2') Including Interactions With Micro-region Size, to Predicted Earnings from Table 5.2, Males Ages 35-49 with 5-8 Years of Education, 1970-2000, Selected Micro-regions (Southeast, South, Center-West).
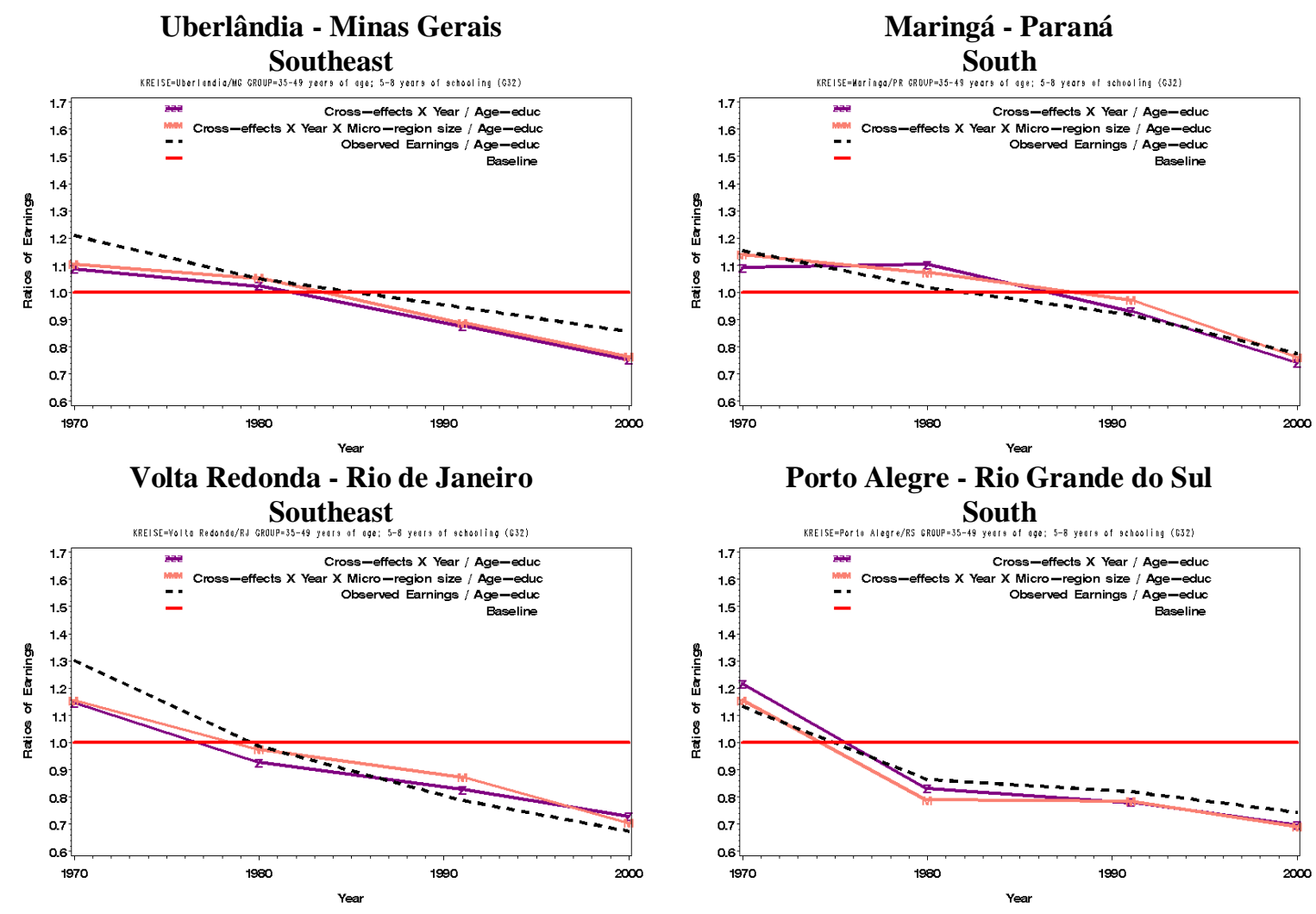

São José do Rio Preto - São Paulo
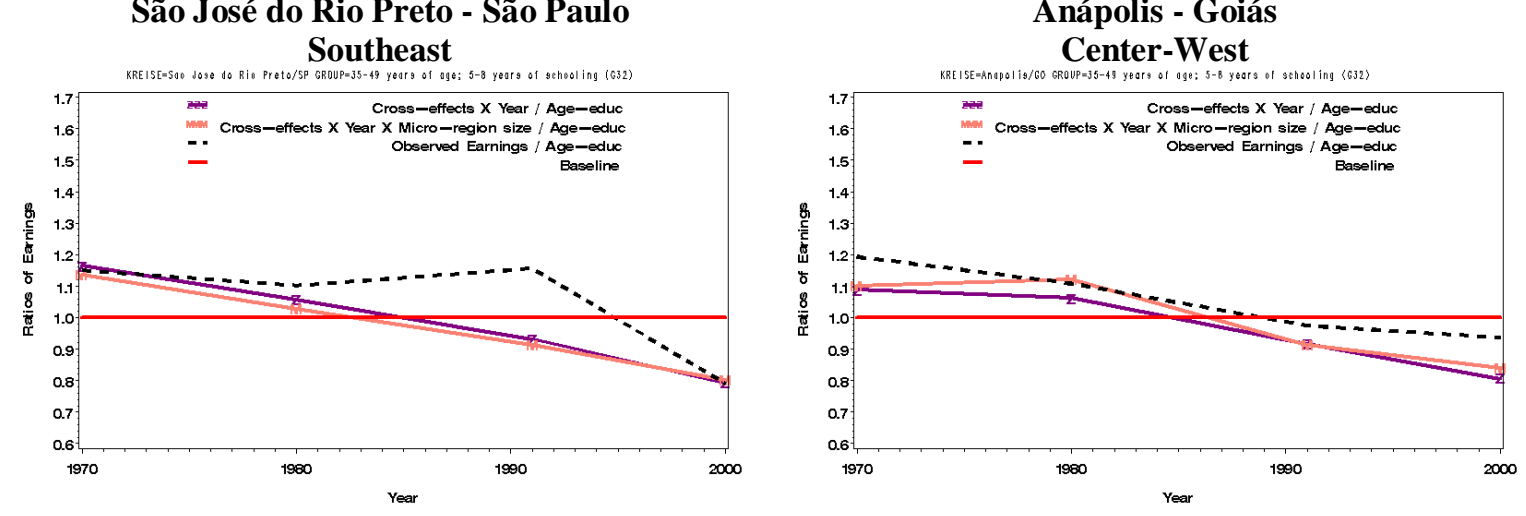

Source: 1970-2000 Brazilian Censuses. 


\section{SUMMARY OF MODELS}

The general conclusion from the findings presented above is that the inclusion of interactions of age-education group proportions with five indicators of major regions, as well as with four indicators of population size of micro-regions do not alter the original Equations (1), (1'), (2) and (2'). The estimated own-quantity elasticities are negative, and in general they are more negative as the skill embodied in the group of workers increases. The impact of proportions on earnings is changing over time, with a decrease in the negative elasticities for the least-educated groups, indicating that the small proportional size of these groups do not have a significant impact on earnings in more recent years. For better educated groups, the negative impact has been increasing over time with slight variations in more recent years. Finally, Table 5.9 illustrates the F-statistics that test whether all coefficients are equal to zero, and whether the area fixed effects are equal to zero for the models discussed above. The fraction of the variance due to the area fixed effects $\left(v_{i}\right)$ - Rho - is included in the table.

As explained above, the maximum number of possible observations in the regression is 24,096, because there are 502 micro-regions, 12 age-education groups and four Censuses. Because of the requirement that the cells should have at least 25 men receiving earnings, there were 19,727 observations throughout the models. In general, the statistics in Table 5.9 indicate that for models with fewer variables, and consequently with fewer coefficients to be estimated, the F-statistics are larger. All models presented significant estimates, suggesting that the null hypothesis is not true. For the model with the highest amount of independent variables $(2,630)$, including cross-proportions interacted with year and five major-region indicators; the fraction of variance due to the area fixed effects was 0.98 . 
Table 5.9. Summary of F-Statistics from the Model Only With Age-Education-Group and Year Indicators, from Equations (1), (1'), (2), (2'), and from Models Including Interactions With Micro-region Size and Region Indicators.

\begin{tabular}{|c|c|c|c|}
\hline Models & All Coefficients $=0$ & $\begin{array}{l}\text { Area Fixed Effects }=0 \\
\left(\text { F-Test that All } v_{i}=0\right)\end{array}$ & $\begin{array}{l}\text { Rho: Fraction of } \\
\text { Variance Due to the } v_{t}\end{array}$ \\
\hline $\begin{array}{l}\text { Model only with year and } \\
\text { age-education indicators }\end{array}$ & $\begin{array}{c}\mathrm{F}(14 ; 19,211): \\
12,941.99 * * *\end{array}$ & $\begin{array}{l}\mathrm{F}(501 ; 19,211): \\
65.13 * * *\end{array}$ & 0.66 \\
\hline $\begin{array}{l}\text { Equation (1): } \\
\text { Own-effects }\end{array}$ & $\begin{array}{c}\mathrm{F}(26 ; 19,199): \\
8,506.08 * * *\end{array}$ & $\begin{array}{c}\mathrm{F}(501 ; 19,199): \\
57.02 * * *\end{array}$ & 0.73 \\
\hline $\begin{array}{c}\text { Equation (1'): } \\
\text { Own-effects X Year }\end{array}$ & $\begin{array}{c}\mathrm{F}(62 ; 19,163): \\
3,957.16^{* * *}\end{array}$ & $\begin{array}{c}\mathrm{F}(501 ; 19,163): \\
53.20^{* * *}\end{array}$ & 0.74 \\
\hline $\begin{array}{l}\text { Equation (2): } \\
\text { Cross-effects }\end{array}$ & $\begin{array}{l}\mathrm{F}(146 ; 19,079): \\
1,808.52^{* * *}\end{array}$ & $\begin{array}{l}\mathrm{F}(501 ; 19,079): \\
20.82 * * *\end{array}$ & 0.68 \\
\hline $\begin{array}{c}\text { Equation (2'): } \\
\text { Cross-effects X Year }\end{array}$ & $\begin{array}{l}\mathrm{F}(542 ; 18,683): \\
538.51 * * *\end{array}$ & $\begin{array}{l}\mathrm{F}(501 ; 18,683): \\
20.87 * * *\end{array}$ & 0.66 \\
\hline $\begin{array}{c}\text { Equation (1) } \\
\text { X Region indicators }\end{array}$ & $\begin{array}{c}\mathrm{F}(74 ; 19,151): \\
3,169.42 * * *\end{array}$ & $\begin{array}{c}\mathrm{F}(501 ; 19,151): \\
27.40 * * *\end{array}$ & 0.69 \\
\hline $\begin{array}{c}\text { Equation (1') } \\
\text { X Region indicators }\end{array}$ & $\begin{array}{l}\mathrm{F}(266 ; 18,959): \\
1,023.04 * * *\end{array}$ & $\begin{array}{c}\mathrm{F}(501 ; 18,959): \\
25.76 * * *\end{array}$ & 0.68 \\
\hline $\begin{array}{c}\text { Equation (2) } \\
\text { X Region indicators }\end{array}$ & $\begin{array}{l}\mathrm{F}(674 ; 18,551): \\
\quad 423.38 * * *\end{array}$ & $\begin{array}{c}\mathrm{F}(501 ; 18,551): \\
13.65^{* * *}\end{array}$ & 0.89 \\
\hline $\begin{array}{c}\text { Equation (2') } \\
\text { X Region indicators }\end{array}$ & $\begin{array}{c}\mathrm{F}(2,630 ; 16,595): \\
125.77 * * *\end{array}$ & $\begin{array}{l}\mathrm{F}(501 ; 16,595): \\
12.19 * * *\end{array}$ & 0.98 \\
\hline $\begin{array}{c}\text { Equation (1) } \\
\text { X Micro-region size }\end{array}$ & $\begin{array}{c}\mathrm{F}(65 ; 19,160): \\
3,510.03 * * *\end{array}$ & $\begin{array}{c}\mathrm{F}(501 ; 19,160): \\
55.16 * * *\end{array}$ & 0.73 \\
\hline $\begin{array}{l}\text { Equation (1') } \\
\text { X Micro-region size }\end{array}$ & $\begin{array}{l}\mathrm{F}(214 ; 19,011): \\
\quad 1,172.15^{* * *}\end{array}$ & $\begin{array}{l}\mathrm{F}(501 ; 19,011): \\
50.75^{* * *}\end{array}$ & 0.73 \\
\hline $\begin{array}{c}\text { Equation (2) } \\
\text { X Micro-region size }\end{array}$ & $\begin{array}{l}\mathrm{F}(545 ; 18,680): \\
504.12 * * *\end{array}$ & $\begin{array}{l}\mathrm{F}(501 ; 18,680): \\
20.53 * * *\end{array}$ & 0.71 \\
\hline $\begin{array}{c}\text { Equation (2') } \\
\text { X Micro-region size }\end{array}$ & $\begin{array}{c}\mathrm{F}(2,040 ; 17,185): \\
150.08 * * *\end{array}$ & $\begin{array}{c}\mathrm{F}(501 ; 17,185): \\
19.26^{* * *}\end{array}$ & 0.68 \\
\hline
\end{tabular}

${ }^{*}$ Significant at $\mathrm{p}<.05 ;{ }^{* *}$ Significant at $\mathrm{p}<.01 ;{ }^{* * *}$ Significant at $\mathrm{p}<.001$.

Source: 1970-2000 Brazilian Censuses. 


\section{Chapter 6. Potential problems on estimated own-quantity elasticities}

\section{INTERNAL MIGRATION IN BRAZIL}

Because the models were estimated at the local level, it would have been important to account for internal migration in the equations. Previous studies about the influence of changing age distribution on economic development did not incorporate the migration variable, because the analysis was done at the national level. Internal migration in Brazil is an important demographic component, since significant population streams from rural to urban areas occurred in previous decades. This migration is characterized by streams from areas of higher fertility rates to those of lower fertility. In other words, internal migration might reduce the differential in birth rates between rural and urban areas. However, this process might also increase the difference in dependency ratios, since migrants are concentrated within working ages. These specificities indicate that models would have to take into account the migration variable, in order to surmise the influence of age structure on economic development.

Caetano (2003) summarizes all migration variables that are available in the 19602000 Brazilian Censuses. He provides a chart including all questions on population flows, attempting to make the variables comparable across the years when they are available in more than one Census. This is the summary of migration variables in Brazilian Censuses provided by Caetano: (1) state or country of birth was obtained in all Censuses; (2) nationality is also available in all Censuses; (3) 1991 and 2000 Censuses provide the year in which foreigners moved to Brazil; (4) 1970-2000 Censuses have information on whether the person was born in the municipality of residence; (5) in the 2000 Census, there is information on whether the person lives in the municipality of residence since birth; (6) 1980 and 1991 Censuses identify if respondent lived in rural and/or urban areas in the 
municipality of residence; (7) in 1991, if the person lived in both rural and urban areas in the municipality, he/she also relays the amount of years of the last movement; (8) all Censuses have information on number of years that the respondent lives in the municipality; (9) 1960-2000 Censuses have information of state or country of previous residence; (10) only 1980 and 1991 Censuses also have information on the municipality of previous residence if the person lived less than ten years in the municipality; (11) the 2000 Census indicates whether the respondent was born in the state of residence; (12) information on the amount of years of continuous residence in the state is available for 1970-2000 Censuses; (13) all Censuses asked respondent whether he/she lived in rural or urban area in the municipality of previous residence; (14) in the 2000 Census, there is information on whether the person lived in this/other municipality, as well as in urban/rural area in July 31, 1995 (five years before the Census); (15) 1991 and 2000 Censuses asked in which municipality and state (or country) the person lived exactly five years before the Census; (16) in 1991 Census, there is specification of the type of area (urban or rural) of the residence five years before the Census (in September 1, 1986); (17) finally, the 2000 Census has information on which municipality and state (or country) the person works or studies.

In a specific study by Greenwood and Sweetland (1972), the determinants of migration between standard metropolitan statistical areas (SMSA) in the United States are analyzed. The gross inter-SMSA migration is explained without any explicit information of an individual decision function. The dependent variable is the ratio of number of migrants who moved from a $\mathrm{SMSA}_{i}$ in 1955 to a $\mathrm{SMSA}_{j}$ in 1960 , by the estimated population of $\mathrm{SMSA}_{j}$ in 1955. The independent variables include aggregate proxy variables that reflect factors that are likely to effect the decision to migrate. Some of these explanatory variables are: distances between areas, male median income in an area, ratios 
of per capita local government expenditures among different areas, and population at the beginning of the period. This study provides a way to analyze migration rates constructing variables from different sources.

Greenwood et al (1991) develop models to measure the impact of regional unemployment rate and relative expected income (RY) on actual labor force participation rates using 1970 and 1980 American Censuses. Models are determined by states, and variables are collected from different sources. Fixed-effects models are estimated because individual effects are associated with each area. Since the relative expected income is endogenous, instrumental variables are used to correct estimates. Because the model is calculated at the state level, authors take into account internal migration, defining economic flows as the difference between actual civilian population under age 65 and estimated civilian population under age 65 in the absence of migration. In order to understand the model estimates, Greenwood et al clarify that:

(...) an equilibrium value of RY of less than unity implies area characteristics that are attractive to individuals such that they are willing to accept lower earnings of pay higher local prices, or both, in order to 'consume' the area's characteristics. Areas with equilibrium RY's that exceed unity have less attractive characteristics, and therefore individuals require a premium in earnings or lower local prices, or both, to be in equilibrium (Greenwood et al 1991, p.1385).

Because Greenwood et al's (1991) model deals with fixed-effects estimates using Census data, this study could be adapted to the Brazilian models presented in previous sections. However, an initial problem would be to collect the necessary information to estimate those models at the micro-region level.

Some other papers deal more with age composition of migrants, but might be relevant to this study. Greenwood et al (1999) gets information from sending-countries to build models that explain rates of U.S. immigration. They use several variables related to differential economic opportunities, migration costs (including distance), political 
conditions, U.S. immigration policy, social programs in the sending-countries, and total population in the sending-countries. The Hausman-Taylor approach, including instrumental variables, is used, because it takes into account factors that differ across countries but are temporally invariant, such as distance from the sending-countries to the United States. Greenwood et al (2003) also estimate Hausman-Taylor models to calculate the impact of social programs in source countries in the age composition of legal U.S. immigrants. Finally, Greenwood (2007) makes use of Hausman-Taylor models with instrumental variables to analyze the age composition of immigrants to the United States using annual data (1972-1991) from 109 source countries.

In the case of Brazil, a study of the composition of migrants with Census data can be done. Basically, the idea is to apply the same models presented by Greenwood and colleagues about the composition of migrants in the United States to the Brazilian context. The model would determine the rate of migration among all micro-regions for each one of the 12 age-education groups discussed in previous sections. This model would take into account age-specific emigration rates, as well as the age composition of these flows. Censuses would be used to organize a data set containing information on: (1) census year; (2) sending state $(i)$; (3) destination state $(j)$; (4) stock of people in the sending area $(i)$ for the 12 age-education groups for males, and the 12 age-education groups for females; (5) stock of people in each age-education-sex group in the destination state $(j)$; (6) stock of males and females in each age-education group in the destination area $(j)$ who were born in the respective sending state (i); (7) stock of people in each age-education-sex group in the destination area $(j)$ that were born in the destination area $(j) ;(8)$ inter-state migrants in the last five years in each age-education-sex group, using information of state of previous residence (variable can also be constructed for the last ten years); (9) earnings for each sex in each age-education group in the sending-state $(i)$; (10) earnings for each age-education- 
sex group in the destination state $(j) ;(11)$ percent of people in each age-education group employed in specific occupation sectors (such as agriculture) in the sending-state $(i)$.

Since the 1960 Census does not have information for all states, and the model proposed by Greenwood and colleagues has to be balanced, the data set could be prepared from 1960 to 2000, only for states also included in 1960; or for the whole country only for Censuses from 1970 to 2000. Moreover, different periods of migration could be also estimated in this kind of analysis. Such as detailed above, migration was considered for flows that took place during the five years before each Census, but migrants in the period of five to ten years before each Census could also be included in the data set.

This approach would provide an informative sign of the magnitude of migration, through the number of recent migrants in each of the age-education-sex groups, as well as the changing proportions of people born out of state in the group. Such as detailed above, this approach is estimated to in-migration, rather than out- migration.

Another way to include population flows in the models is through the estimation of net migration. One difficulty is that it would be hard to estimate net migration of the youngest age-education groups by way of survival from the previous Census. However, even with this limitation of Census information on migration, Rogers and Jordan (2004) develop and demonstrate a method that uses the population totals in the first age group of birthplace-specific population data to indirectly infer the entire age schedule of directional age-specific migration flows. They focus the analysis on the internal migration of the U.S.born population. Rogers and Jordan suggest the use of the "multiexponential function," estimating parameters with a nonlinear algorithm that searches for the best parameter values for the model migration schedule. This technique of birthplace-specific population stocks of infants could be used to generate more accurate age-specific migration rates for all 502 Brazilian micro-regions. 
Such as discussed in previous sections, Borjas (2003) suggests that studies about the impact of immigration on labor market were mainly based on the comparison of employment opportunities between immigrants and natives across regions. The main conclusion was usually that immigrants do not lower native wages. Using a new approach based on the assumption that similarly educated workers with different levels of experience are not perfect substitutes, Borjas suggests that immigration reduces the wage and labor supply of competing native workers. However, since internal population flows in Brazil are influenced by availability of jobs and levels of income in sending and receiving areas, migration is an endogenous variable that could not be simply introduced as an exogenous variable in the estimation of labor outcomes.

In general, the studies above illustrate some possibilities to the estimation and implementation of migration information on regression models. The use of aggregate proxy variables from different sources would minimize the dependence of migration estimation on Census data. The use of instrumental variables could be a strategy to control for endogeneity of the estimated age-specific migration rates. The study of age-education composition of migrants could be a tool to correct the models shown in previous sections.

Finally, gravity models, taking into account distances among areas, could also be used to control for migration flows. More than distance, these gravity models could take into account the changing population in the micro-regions over time, as well as the proportion of migrants already living in a specific area in a given Census. The idea is to use distance among micro-regions, population growth, and income trend over time to create an index to be used as an instrumental variable in the equations. Distance is constant over time, but the micro-regions population growth changes their out- and in-migration trends. Micro-regions that have a growing mean income trend over time are more susceptible to attracting migrants. More specifically, Brazilian Census Bureau shapefiles would generate 129 
a matrix with distances among all micro-regions. The weighted number of men in the micro-regions, available in the databases, could be used to generate a population growth measure over time. Finally, the logarithm of mean earnings in each micro-region and year would be used to generate the income trend over time. Thus the combination of distance, population growth and mean income trend over time can be used to generate attraction and repulsion measures of population flows among micro-regions.

However, these model alternatives are not estimated at this point, because they would create a whole new research project. An analysis of how ignoring migration biases the own-quantity elasticities is done in the following section.

\section{ROBUSTNESS CONSIDERATIONS}

Remembering that the purpose has been to examine the impacts of changing endowments of labor by type (in this case, age and education), one needs to inquire whether the strong evidence uncovered here, that there are substantial negative own-quantity elasticities of factor prices, is robust to a number of potential problems. Consider first the issue of inter-micro-regional migration. Ideally one might embed the production models estimated here in a more general model in which population is determined endogenously with wages through endogenous flows of migrants. However, new models were not estimated, due to the difficulty in calculating instruments, such as discussed above. These instruments might have been used to remove any problems of endogeneity in the ageeducation distributions, that are used here as regressors.

Not taking into account any instruments, it is important to consider the direction of the bias in the estimated own-quantity elasticities that might be induced by endogenous inter-area migration. Such migration presumably flows to those areas where relative 
declines in the size of the labor force in a particular age-education category have raised wage rates. If so, migration flows reduce wage rates in precisely those areas and among those age-education groups where natural (pre-migration) scarcities would have raised wages. Endogenous migration thus biases the estimated negative own-quantity effects on wages toward zero and thus implies, assuming migrants respond to relative wage differentials, that above estimates understate the absolute value of the effects that have been tried to be measured.

Whether the biases induced by endogenous migration differ by age-education category is a more difficult question and depends largely on differences in the responsiveness of migration to wage differentials by age-education category. Certainly it is known that in Brazil, as elsewhere, migration is disproportionate among younger workers; and there is also evidence that Brazilian migration is greatest among the leasteducated. There is little known, however, about differences in the responsiveness of migration to wages by age-education group. If, however, the elasticities of migration with respect to wages are, like labor-supply elasticities, greater for less-skilled workers, that would suggest that the positive biases on the own-quantity factor-price elasticities are greater for less-skilled workers — in this study, the young and the least-educated.

A similar problem might arise if educational attainment is endogenous — if within micro-regions young people attain more schooling when the returns to education have increased because more educated labor has become relatively scarce. If this occurs, the response would raise quantity endowments and reduce relative wages among those laborforce groups whose relative wage rates would otherwise have risen still further. Like the biases in own-quantity factor-price elasticities potentially induced by endogenous migration, those potentially induced by endogenous educational choices also reduce the absolute values of the (negative) estimated parameters below their true values. 
Other potential difficulties might arise from the implicit assumption that the subaggregates of male labor are separable in production from those of other inputs, including capital and female labor. In the broad labor-demand literature formal tests of separability almost always reject that assumption (Hamermesh 1993, chapter 3). Without data on capital stocks by area, it is not possible to re-specify the model to account for this nonseparability problem. The literature suggests quite clearly, however, that capital and skill are $p$-complements, so that it is expected the returns to skill will be greater in those areas where production is more physical-capital intensive. Coupled with a probable positive correlation between skill intensity and endowments of physical capital, this correlation means that any misspecification resulting from the absence of data on physical capital will bias the estimated own-quantity factor-price elasticities among more skilled workers toward zero.

The same Census information by micro-region on the age-education structure of the female workforce is available as it is for males. It would be possible thus to include these distributions as additional $X_{c}$, variables in estimating (2), thus allowing for crosseffects of relative quantities of female workers on male relative wages. The difficulties with doing this are several. Most importantly, the distributions of female workers are highly correlated with those of male workers. Where and when the male workforce is older, so is the female workforce; where and when men are better educated, so are women. How excluding quantities of female workers from the equations biases the estimated ownquantity factor-price elasticities for male workers depends on both this positive correlation and the substitution/complementarity relationships between male and female workers within and across age-education categories. There is no evidence on these latter correlations, so that in the end the direction of any bias is an empirical issue. However, the endowments of female workers were added to a set of re-estimates of (2); not surprisingly, 
the high positive correlations between the male and female distributions across the ageeducation categories within areas caused the standard errors to increase greatly. 


\section{Chapter 7. Implications for public policies}

Some consideration should be given to the implications for public policies originating from the analysis in this study. The decomposition of the impact of changes in age-education groups on earnings provides insight about the separated impact of age and education changes.

One can hold constant the age structure from the 1970 Census, and use the education structure from the 2000 Census to estimate earnings in 2000. Comparing these new estimated earnings to the original 2000 predicted earnings (using age and education structures from 2000) measures the effect of changing age composition on earnings. For example, if age structure had remained the same from 1970 to 2000, one can compare these new results to the 2000 original predicted values to verify that groups who experienced proportional increases over time (age-groups 25-34, 35-49, and 50-64) had smaller original earnings in 2000, compared to the earnings with constant age structure. In the opposite case, earnings in 2000 can be predicted utilizing the 1970 education structure and the 2000 age structure. These new estimated earnings can be compared to the 2000 original predicted earnings to analyze the impact of changing education composition on earnings.

These estimates can be conducted utilizing the same strategies that produced Figures 5.18 and 5.19. First of all, national proportions of males by age-education group and Census year (Table 5.1) were used to generate two new sets of national proportions: (1) holding age composition constant from 1970; and (2) holding education composition constant from 1970. In an additional step, these two new standardized compositions were used to forecast four sets of earnings: (1) two sets of earnings were generated applying the coefficients from the own-effects model (Table 5.3) and are shown in Table 7.1; and (2) 
two sets of earnings were estimated using the coefficients from the own-effects model interacted with year indicators (Table 5.4) and are illustrated in Table 7.2.

Thus, Tables 7.1 and 7.2 show: (1) the 1970 predicted earnings, utilizing the 1970 actual age-education structure; (2) the 2000 predicted earnings, using the 2000 actual ageeducation distribution; (3) the 2000 predicted earnings, employing the 2000 actual education composition, and the 1970 age structure; (4) and the 2000 predicted earnings, utilizing the 2000 actual age structure, and the 1970 education composition. 
Table 7.1. Effects of Age and Education Distributions on Predicted Earnings ${ }^{+}$from Equation (1) by Age-Education Groups, 1970 and 2000.

\begin{tabular}{|c|c|c|c|c|}
\hline \multirow{2}{*}{$\begin{array}{l}\text { Age-Education } \\
\text { Group }\end{array}$} & \multirow{2}{*}{$\begin{array}{c}1970 \text { Actual } \\
\text { Predicted Earnings }\end{array}$} & \multicolumn{3}{|c|}{2000 Predicted Earnings Using: } \\
\hline & & $\begin{array}{l}2000 \text { Actual } \\
\text { Age-Education } \\
\text { Distribution } \\
\end{array}$ & $\begin{array}{l}2000 \text { Actual Education, } \\
\text { and } 1970 \text { Age } \\
\text { Distribution }\end{array}$ & $\begin{array}{l}2000 \text { Actual Age, } \\
\text { and } 1970 \text { Education } \\
\text { Distribution }\end{array}$ \\
\hline $\begin{array}{c}15-24 \text { years } \\
0-4 \text { years of schooling }\end{array}$ & 162.81 & 202.03 & 201.81 & 200.53 \\
\hline $\begin{array}{c}15-24 \text { years } \\
5-8 \text { years of schooling }\end{array}$ & 252.41 & 243.73 & 229.60 & 321.10 \\
\hline $\begin{array}{c}15-24 \text { years } \\
9+\text { years of schooling }\end{array}$ & 386.89 & 329.49 & 306.83 & 480.39 \\
\hline $\begin{array}{c}25-34 \text { years } \\
0-4 \text { years of schooling }\end{array}$ & 236.21 & 300.46 & 300.81 & 290.72 \\
\hline $\begin{array}{c}25-34 \text { years } \\
5-8 \text { years of schooling }\end{array}$ & 500.30 & 435.64 & 442.69 & 590.64 \\
\hline $\begin{array}{c}25-34 \text { years } \\
9+\text { years of schooling }\end{array}$ & 905.35 & 796.27 & 808.72 & $1,111.79$ \\
\hline $\begin{array}{c}35-49 \text { years } \\
0-4 \text { years of schooling }\end{array}$ & 293.24 & 400.16 & 406.05 & 341.30 \\
\hline $\begin{array}{c}35-49 \text { years } \\
5-8 \text { years of schooling }\end{array}$ & 722.59 & 610.31 & 638.24 & 843.60 \\
\hline $\begin{array}{c}35-49 \text { years } \\
9+\text { years of schooling }\end{array}$ & $1,391.23$ & $1,375.81$ & $1,409.14$ & $1,679.37$ \\
\hline $\begin{array}{c}50-64 \text { years } \\
0-4 \text { years of schooling }\end{array}$ & 309.80 & 394.42 & 399.25 & 331.58 \\
\hline $\begin{array}{c}50-64 \text { years } \\
5-8 \text { years of schooling }\end{array}$ & 824.87 & 811.51 & 830.70 & $1,005.31$ \\
\hline $\begin{array}{c}50-64 \text { years } \\
9+\text { years of schooling }\end{array}$ & $1,556.92$ & $1,891.74$ & $1,892.67$ & $1,901.83$ \\
\hline
\end{tabular}

${ }^{+}$Nominal income was converted to base 1 in January 2002, taking into account changes in currency and inflation.

Source: 1970-2000 Brazilian Censuses. 
Table 7.2. Effects of Age and Education Distributions on Predicted Earnings ${ }^{+}$from Equation (1') by Age-Education Groups, 1970 and 2000.

\begin{tabular}{|c|c|c|c|c|}
\hline \multirow{2}{*}{$\begin{array}{l}\text { Age-Education } \\
\text { Group }\end{array}$} & \multirow{2}{*}{$\begin{array}{c}1970 \text { Actual } \\
\text { Predicted Earnings }\end{array}$} & \multicolumn{3}{|c|}{2000 Predicted Earnings Using: } \\
\hline & & $\begin{array}{l}2000 \text { Actual } \\
\text { Age-Education } \\
\text { Distribution } \\
\end{array}$ & $\begin{array}{l}2000 \text { Actual Education, } \\
\text { and } 1970 \text { Age } \\
\text { Distribution }\end{array}$ & $\begin{array}{l}2000 \text { Actual Age, } \\
\text { and } 1970 \text { Education } \\
\text { Distribution }\end{array}$ \\
\hline $\begin{array}{c}15-24 \text { years } \\
0-4 \text { years of schooling }\end{array}$ & 161.01 & 206.49 & 204.45 & 192.58 \\
\hline $\begin{array}{c}15-24 \text { years } \\
5-8 \text { years of schooling }\end{array}$ & 254.35 & 268.63 & 245.19 & 409.39 \\
\hline $\begin{array}{c}15-24 \text { years } \\
9+\text { years of schooling }\end{array}$ & 430.20 & 321.84 & 299.68 & 469.45 \\
\hline $\begin{array}{c}25-34 \text { years } \\
0-4 \text { years of schooling }\end{array}$ & 225.60 & 312.56 & 314.13 & 271.04 \\
\hline $\begin{array}{c}25-34 \text { years } \\
5-8 \text { years of schooling }\end{array}$ & 533.62 & 445.95 & 454.15 & 629.99 \\
\hline $\begin{array}{c}25-34 \text { years } \\
9+\text { years of schooling }\end{array}$ & $1,040.79$ & 812.09 & 815.46 & 887.72 \\
\hline $\begin{array}{c}35-49 \text { years } \\
0-4 \text { years of schooling }\end{array}$ & 269.80 & 404.40 & 414.40 & 310.07 \\
\hline $\begin{array}{c}35-49 \text { years } \\
5-8 \text { years of schooling }\end{array}$ & 788.13 & 609.37 & 642.95 & 898.28 \\
\hline $\begin{array}{c}35-49 \text { years } \\
9+\text { years of schooling }\end{array}$ & $1,536.64$ & $1,281.75$ & $1,328.73$ & $1,729.86$ \\
\hline $\begin{array}{c}50-64 \text { years } \\
0-4 \text { years of schooling }\end{array}$ & 276.26 & 414.27 & 424.84 & 289.37 \\
\hline $\begin{array}{c}50-64 \text { years } \\
5-8 \text { years of schooling }\end{array}$ & 941.57 & 814.89 & 825.19 & 914.27 \\
\hline $\begin{array}{c}50-64 \text { years } \\
9+\text { years of schooling }\end{array}$ & $1,687.24$ & $1,422.78$ & $1,469.16$ & $2,013.55$ \\
\hline
\end{tabular}

${ }^{+}$Nominal income was converted to base 1 in January 2002, taking into account changes in currency and inflation.

Source: 1970-2000 Brazilian Censuses. 
Analyzing the results in the third column of Tables 7.1 and 7.2, one can see that mean real earnings would have been smaller for the youngest age group (15-24), when holding age composition constant, compared to original estimates (second column). Predicted earnings are greater for the other age groups compared to original estimates, because the aging process experienced by the Brazilian population increased the share of these age groups, with a result of even smaller original predicted earnings (second column) compared to the case of age composition constant (third column).

Results from estimates holding education constant from 1970 to 2000 (fourth column) indicate that, for groups with greater levels of education (five to eight years of schooling, and at least nine years of schooling), earnings of these workers would have been larger than the original estimates at the end of the period. This provides evidence that the improvement in education attainment over time increased the share of workers with better education, lowering their income. Groups in the lowest educated level (zero to four years of schooling) would have experienced a decrease in their earnings with a constant education structure from 1970 to 2000 , compared to original predictions. This fact is verified because since the lowest educated groups represented a greater share in the 1970 population compared to the 2000 population, their earnings would have fallen considerably if they remained a significant portion of the population.

In general, results in Tables 7.1 and 7.2 suggest that changes in the education distribution are the ones that generated the greatest impacts on earnings over time. When holding 1970 education composition constant (fourth column), the predicted earnings have values more unlike the original 2000 predicted earnings (second column) than when holding age composition constant (third column). Thus, changing education composition over time, within labor force ages (15-64), generated greater impacts on worker earnings than changes in age structure. 
Improvements in education attainment generated lower earnings for better educated workers compared to the estimates holding education constant from 1970. However, an important result is that if the education had maintained constant over time, the lowest educated workers would have experienced even smaller earnings than illustrated by the original predictions. More specifically, earnings inequality between the least educated group (zero to four years of schooling) and the other education groups, within each age group, would have been even greater than the one predicted with the age-education composition in 2000. Thus, the improvement in education attainment from 1970 to 2000 was an important aspect towards reducing economic inequality in Brazil.

Moreover, changes in age structure also decreased earnings inequality between the youngest age group (15-24) compared to the other age groups. This assessment is supported by the finding that mean real earnings would have been smaller for the youngest age group, and bigger for the other ones, if the age composition had remained the same from 1970 to 2000 . Thus, fertility decline had a central role in the reduction of income inequality in the country, because it generated a decrease in the proportion of younger groups in the labor market.

Since there is great variation in age and education compositions across Brazilian micro-regions, such as illustrated in this study, important policies to decrease even further income inequality in the country would be to improve education attainment in areas that still have large proportions of people with lower levels of schooling, as well as to promote family planning programs in regions that still have higher levels of fertility.

In order to better understand the separate impact of changing age and education compositions over time in the predicted earnings, a set of figures were estimated using the same procedures that were used to construct Figures 5.18 and 5.19. The national ageeducation proportions, holding age composition constant from 1970 to 2000, and holding 
education composition constant from 1970 to 2000, were utilized for this exercise, as well as coefficients in Tables 5.3 and 5.4.

Figures 7.1 to 7.4 plot the ratio of predicted earnings from the own-effects model (Table 5.3), and from the own-effects model interacted with year (Table 5.4), to predicted earnings from the model that includes only indicators for age-education groups and years (Table 5.2). The horizontal line is set to be equal to one, and shows the model that excludes the proportions in each age-education group (Table 5.2). As in Figures 5.18 and 5.19, the new figures demonstrate that groups with decreasing proportions have gains in earnings, and those with growing proportions experience a decline in earnings over time.

Figures 7.1 illustrates estimates from the own-effects model (Equation (1)), holding national age distribution constant from 1970 to 2000; Figure 7.2 shows estimates from Equation (1), holding national education distribution constant from 1970 to 2000; Figure 7.3 demonstrates predictions from own-effects model interacted with year indicators (Equation (1')), holding age distribution constant; and Figure 7.4 shows estimates from Equation (1'), holding education distribution constant. The scale in the vertical axis is the same in Figures 5.18, 5.19, 7.1, 7.2, 7.3, and 7.4 for comparison purposes.

Figure 7.1 indicates that, holding age composition constant from 1970 to 2000, the ratios of predicted earnings from Equation (1) to the baseline model would be lower for the lowest age group (15-24) compared to the results in Figure 5.18. On the other hand, older age groups (35-49 and 50-64) have higher ratios than the previous results. These patterns show that maintaining a younger age composition constant over time, would decrease the earnings of younger males, and increase those of older males.

The general tendency illustrated in Figure 7.2 is that ratios for the lowest educated group (zero to four years of schooling) are smaller compared to the ones in Figure 5.18, and ratios for the groups with higher education are bigger than in the previous results. 
These findings demonstrate that, keeping education distribution constant from 1970 to 2000, estimates from Equation (1) will have greater negative impacts for the group with bigger proportions in 1970 (zero to four years of schooling), than for education groups with smaller proportions at the beginning of the period.

Figures 7.3 and 7.4 have to be compared to Figure 5.19, because they illustrate results from Equation (1'). Figure 7.1 indicated that holding the younger age composition in 1970 constant, it would decrease earnings of younger males, and increase earnings in older groups. When interactions of year indicators with age-education group proportions are included in the model, the new results in Figure 7.3 suggest that the gains and losses in predicted ratios for the several age-education groups have a similar pattern to the original estimates (Figure 5.19). Figure 7.4 shows predicted ratios holding education distribution constant from 1970 to 2000 . In this case, it is clear that for the education group (zero to four years of schooling) that had greater proportions in 1970, the new predicted earnings are lower compared to the ones in Figure 5.19. On the other hand, groups with lower proportions in 1970 (five to eight years of schooling, and at least nine years of schooling) have higher predicted ratios than the results in Figure 5.19. 
Figure 7.1. Ratios of Predicted Earnings from Equation (1) to Predicted Earnings from Table 5.2, using the National Age-Education Distribution, and Maintaining the 1970 Age Distribution Constant, 1970-2000.

\section{Men 15-24}

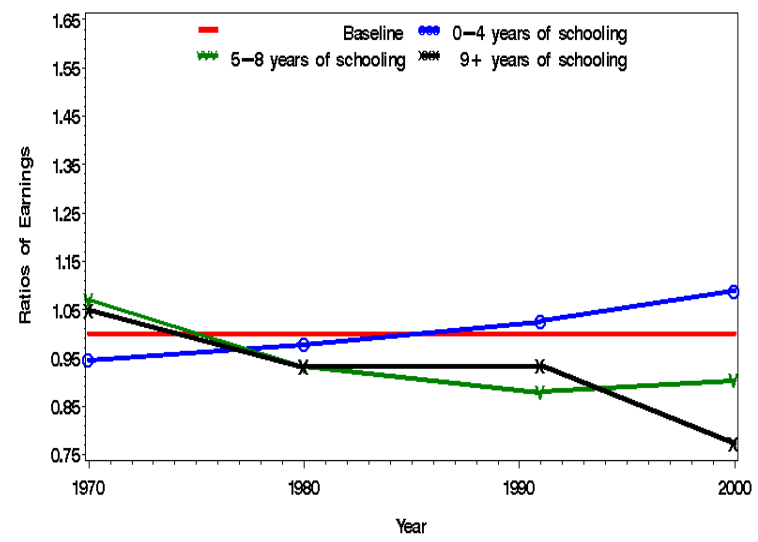

Men 35-49

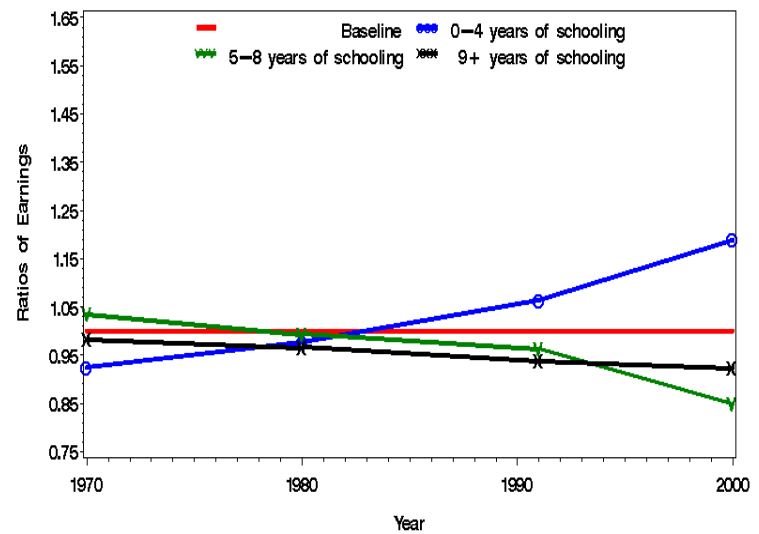

Men 25-34

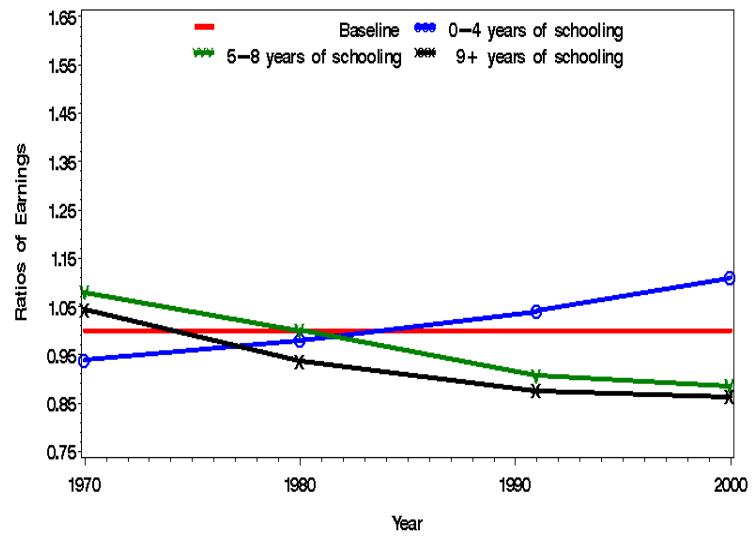

Men 50-64

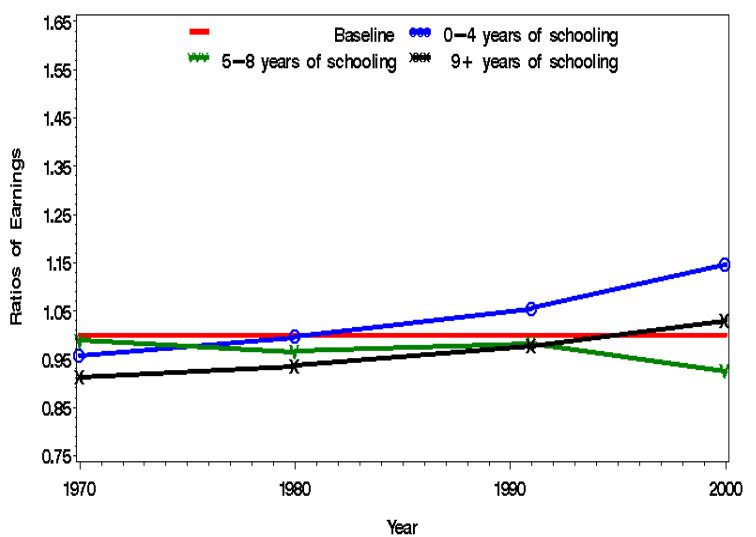

Note: The scale in the vertical axis is the same in Figures 5.18, 5.19, 7.1, 7.2, 7.3, and 7.4 for comparison purposes. Source: 1970-2000 Brazilian Censuses. 
Figure 7.2. Ratios of Predicted Earnings from Equation (1) to Predicted Earnings from Table 5.2, using the National Age-Education Distribution, and Maintaining the 1970 Education Distribution Constant, 1970-2000.

Men 15-24

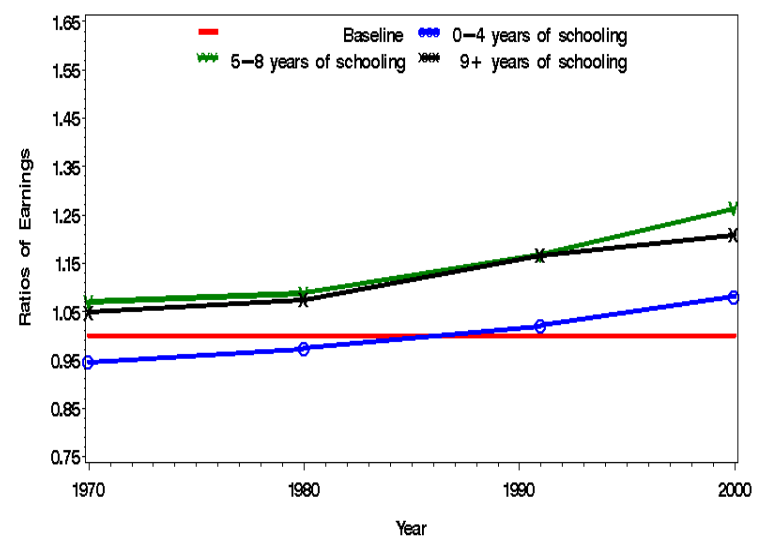

Men 35-49

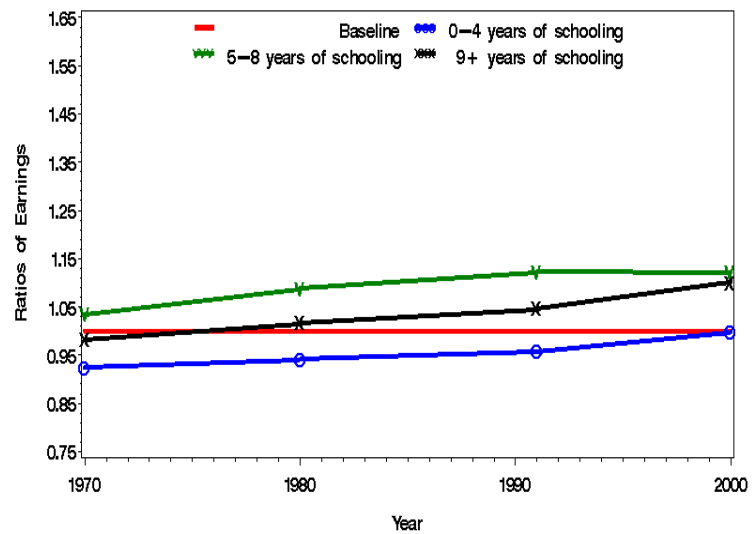

Men 25-34

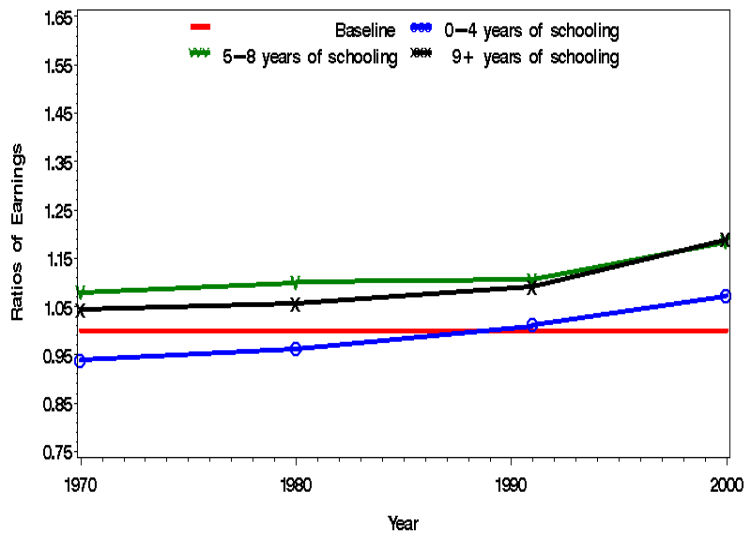

Men 50-64

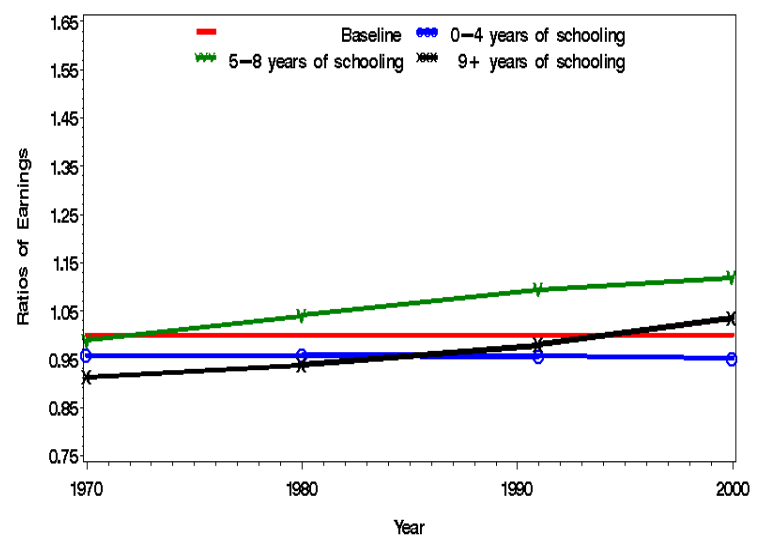

Note: The scale in the vertical axis is the same in Figures 5.18, 5.19, 7.1, 7.2, 7.3, and 7.4 for comparison purposes. Source: 1970-2000 Brazilian Censuses. 
Figure 7.3. Ratios of Predicted Earnings from Equation (1') to Predicted Earnings from Table 5.2, using the National Age-Education Distribution, and Maintaining the 1970 Age Distribution Constant, 1970-2000.

\section{Men 15-24}

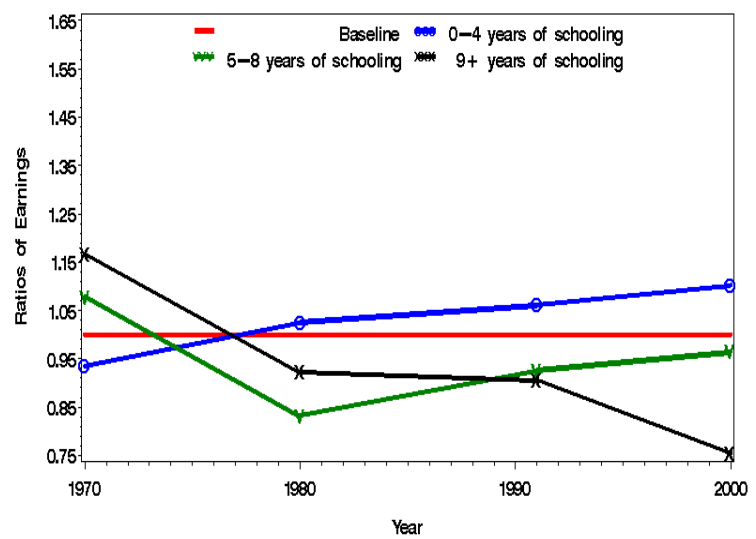

Men 35-49

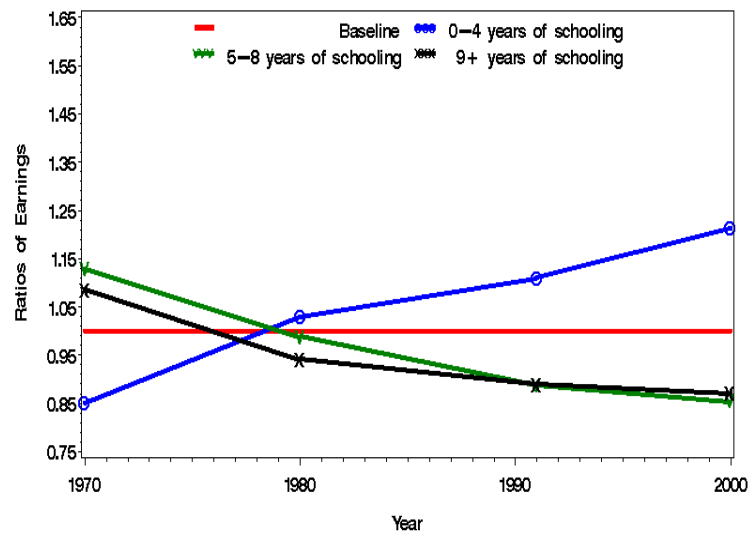

Men 25-34

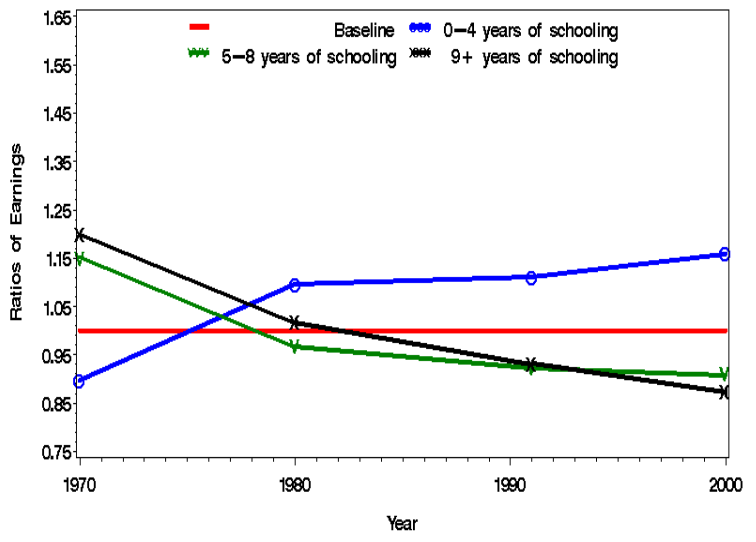

Men 50-64

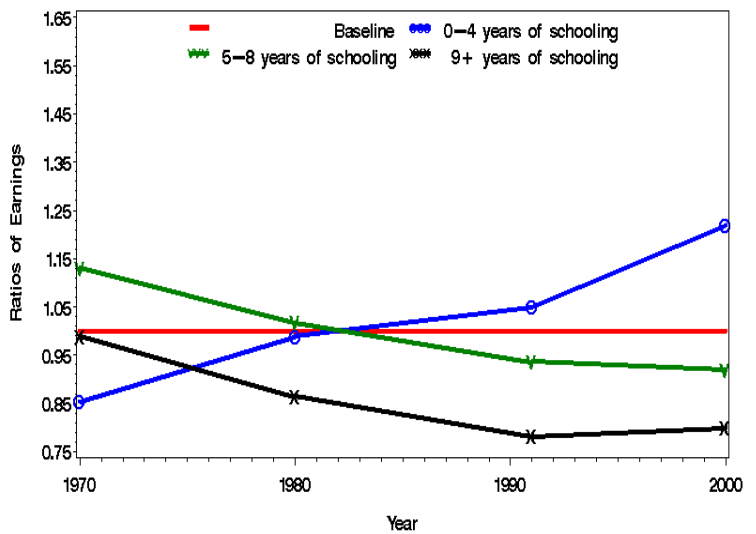

Note: The scale in the vertical axis is the same in Figures 5.18, 5.19, 7.1, 7.2, 7.3, and 7.4 for comparison purposes. Source: 1970-2000 Brazilian Censuses. 
Figure 7.4. Ratios of Predicted Earnings from Equation (1') to Predicted Earnings from Table 5.2, using the National Age-Education Distribution, and Maintaining the 1970 Education Distribution Constant, 1970-2000.

Men 15-24

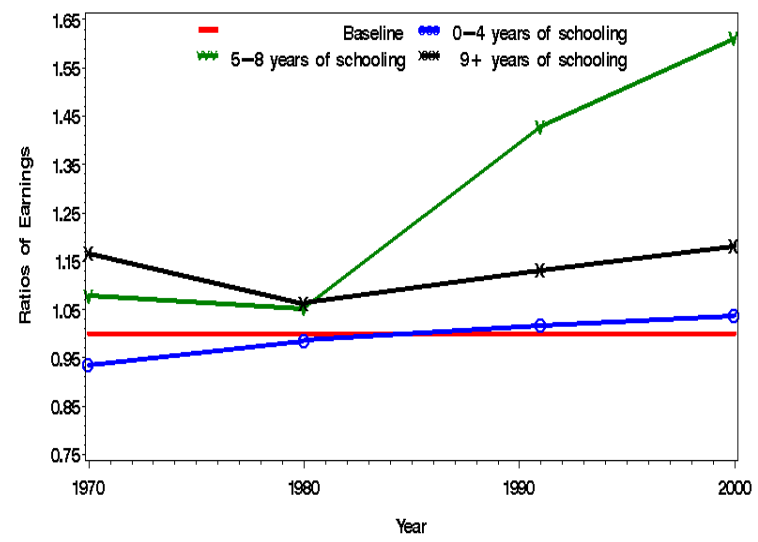

Men 35-49

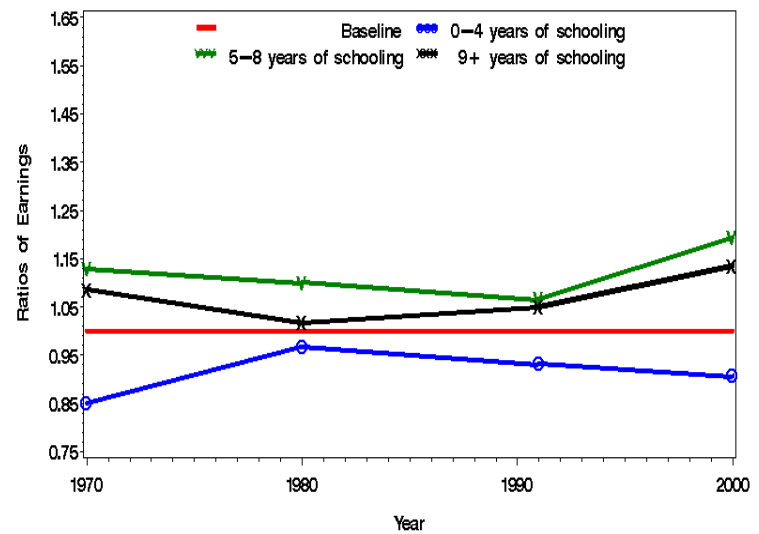

Men 25-34

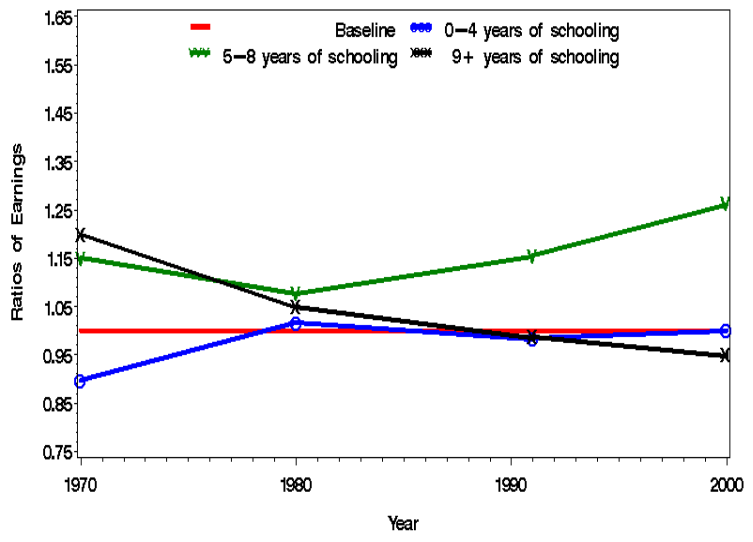

Men 50-64

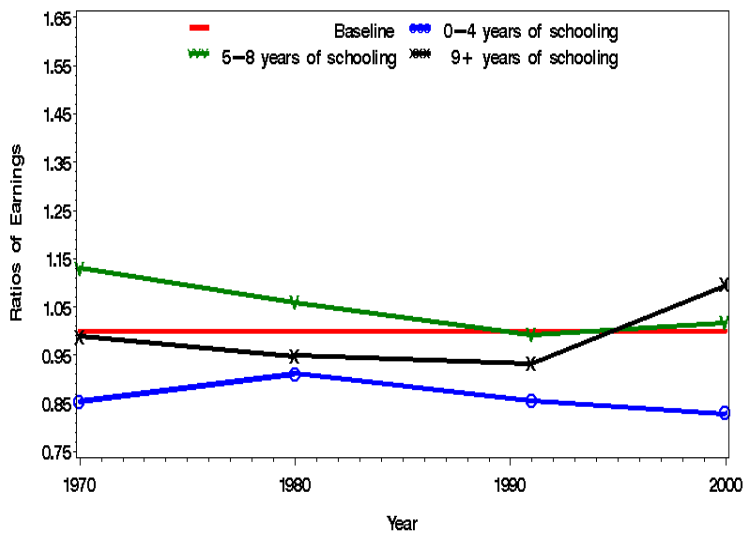

Note: The scale in the vertical axis is the same in Figures 5.18, 5.19, 7.1, 7.2, 7.3, and 7.4 for comparison purposes. Source: 1970-2000 Brazilian Censuses. 
Calculations of Gini coefficients are presented in the following tables in order to measure the inequality of the income distribution among age-education groups. The income is more equally distributed among groups, when the coefficient is closer to zero. When the coefficient is closer to one, the income is more unequally distributed. A coefficient equal to zero corresponds to perfect income equality, i.e. everyone has the same income. A coefficient equal to one indicates a perfect income inequality, i.e. one group has all the income, while everyone else has zero income.

These coefficients are a more appropriate measure to estimate income inequality than the predicted earnings presented in Tables 7.1 and 7.2. This improvement happens because Gini coefficients take into account not only the income distributions presented in Tables 7.1 and 7.2, but also the specific national age-education distributions used to calculate those predicted earnings.

More specifically, Gini coefficients that used predicted national earnings from Equation (1) in Table 7.1, utilized: (1) in Tables 7.3 and 7.4, national age-education distribution in Table 5.1; (2) in Table 7.5, national age-education distribution, holding age composition constant from 1970 to 2000; and (3) in Table 7.6, national age-education distribution, maintaining education composition constant from 1970 to 2000 .

The estimates from Equation (1') in Table 7.2 were used to calculate Gini coefficients: (1) in Tables 7.7 and 7.8, with national age-education distribution in Table 5.1; (2) in Table 7.9, using national age-education distribution, maintaining age composition constant from 1970 to 2000; and (3) in Table 7.10, utilizing national ageeducation composition, holding education distribution constant from 1970 to 2000 . 
Table 7.3. Gini Coefficient Calculation Using Predicted National Earnings ${ }^{+}$from Equation (1) and National Age-Education Distribution, 1970.

\begin{tabular}{|c|c|c|c|c|c|c|c|}
\hline \multirow[t]{2}{*}{$\begin{array}{l}\text { Age-Education } \\
\text { Group }\end{array}$} & $\begin{array}{c}\text { Income } \\
\text { Table 7.1 } \\
\text { (column 1) } \\
\end{array}$ & $\begin{array}{c}\text { Income } \\
\text { Distribution }\end{array}$ & $\begin{array}{c}\text { Age-Educ. } \\
\text { Distribution } \\
\text { Table 5.1 } \\
\end{array}$ & $\begin{array}{l}\text { Cumulative } \\
\text { Income }\end{array}$ & $\begin{array}{l}\text { Cumulative } \\
\text { Age-Educ. } \\
\text { Distribution }\end{array}$ & $\left(e_{i}\right) *\left(d_{i+1}\right)$ & $\left(\mathbf{d}_{\mathbf{i}}\right)^{*}\left(\mathbf{e}_{\mathbf{i}+1}\right)$ \\
\hline & (a) & (b) & (c) & (d) & (e) & (f) & (g) \\
\hline $\begin{array}{c}15-24 \text { years } \\
0-4 \text { years of schooling }\end{array}$ & 162.81 & 0.022 & 0.282 & 0.022 & 0.282 & 0.016 & 0.007 \\
\hline $\begin{array}{c}15-24 \text { years } \\
5-8 \text { years of schooling }\end{array}$ & 252.41 & 0.033 & 0.054 & 0.055 & 0.336 & 0.036 & 0.020 \\
\hline $\begin{array}{c}15-24 \text { years } \\
9+\text { years of schooling }\end{array}$ & 386.89 & 0.051 & 0.027 & 0.106 & 0.363 & 0.050 & 0.060 \\
\hline $\begin{array}{c}25-34 \text { years } \\
0-4 \text { years of schooling }\end{array}$ & 236.21 & 0.031 & 0.197 & 0.138 & 0.560 & 0.114 & 0.080 \\
\hline $\begin{array}{c}25-34 \text { years } \\
5-8 \text { years of schooling }\end{array}$ & 500.30 & 0.066 & 0.020 & 0.204 & 0.580 & 0.188 & 0.122 \\
\hline $\begin{array}{c}25-34 \text { years } \\
9+\text { years of schooling }\end{array}$ & 905.35 & 0.120 & 0.020 & 0.324 & 0.600 & 0.218 & 0.268 \\
\hline $\begin{array}{c}35-49 \text { years } \\
0-4 \text { years of schooling }\end{array}$ & 293.24 & 0.039 & 0.227 & 0.363 & 0.827 & 0.379 & 0.306 \\
\hline $\begin{array}{c}35-49 \text { years } \\
5-8 \text { years of schooling }\end{array}$ & 722.59 & 0.096 & 0.016 & 0.459 & 0.843 & 0.542 & 0.394 \\
\hline $\begin{array}{c}35-49 \text { years } \\
9+\text { years of schooling }\end{array}$ & $1,391.23$ & 0.184 & 0.016 & 0.643 & 0.859 & 0.588 & 0.635 \\
\hline $\begin{array}{c}50-64 \text { years } \\
0-4 \text { years of schooling }\end{array}$ & 309.80 & 0.041 & 0.128 & 0.684 & 0.987 & 0.784 & 0.680 \\
\hline $\begin{array}{c}50-64 \text { years } \\
5-8 \text { years of schooling }\end{array}$ & 824.87 & 0.109 & 0.007 & 0.794 & 0.994 & 0.994 & 0.794 \\
\hline $\begin{array}{c}50-64 \text { years } \\
9+\text { years of schooling }\end{array}$ & $1,556.92$ & 0.206 & 0.006 & 1.000 & 1.000 & - & - \\
\hline Total & $7,542.62$ & 1.0 & 1.0 & - & - & 3.908 & 3.365 \\
\hline
\end{tabular}

Gini Coefficient $[\operatorname{sum}(\mathbf{f})-\operatorname{sum}(\mathrm{g})]=\quad \mathbf{0 . 5 4 2}$

\footnotetext{
${ }^{+}$Nominal income was converted to base 1 in January 2002, taking into account changes in currency and inflation.

Source: 1970-2000 Brazilian Censuses.
} 
Table 7.4. Gini Coefficient Calculation Using Predicted National Earnings ${ }^{+}$from Equation (1) and National Age-Education Distribution, 2000.

\begin{tabular}{|c|c|c|c|c|c|c|c|}
\hline \multirow[t]{2}{*}{$\begin{array}{l}\text { Age-Education } \\
\text { Group }\end{array}$} & $\begin{array}{c}\text { Income } \\
\text { Table 7.1 } \\
\text { (column 2) } \\
\end{array}$ & $\begin{array}{c}\text { Income } \\
\text { Distribution }\end{array}$ & $\begin{array}{c}\text { Age-Educ. } \\
\text { Distribution } \\
\text { Table 5.1 } \\
\end{array}$ & $\begin{array}{l}\text { Cumulative } \\
\text { Income }\end{array}$ & $\begin{array}{l}\text { Cumulative } \\
\text { Age-Educ. } \\
\text { Distribution }\end{array}$ & $\left(e_{i}\right) *\left(d_{i+1}\right)$ & $\left(d_{i}\right) *\left(e_{i+1}\right)$ \\
\hline & (a) & (b) & (c) & (d) & (e) & (f) & (g) \\
\hline $\begin{array}{c}15-24 \text { years } \\
0-4 \text { years of schooling }\end{array}$ & 202.03 & 0.026 & 0.090 & 0.026 & 0.090 & 0.005 & 0.006 \\
\hline $\begin{array}{c}15-24 \text { years } \\
5-8 \text { years of schooling }\end{array}$ & 243.73 & 0.031 & 0.125 & 0.057 & 0.215 & 0.021 & 0.018 \\
\hline $\begin{array}{c}15-24 \text { years } \\
9+\text { years of schooling }\end{array}$ & 329.49 & 0.042 & 0.102 & 0.099 & 0.317 & 0.044 & 0.040 \\
\hline $\begin{array}{c}25-34 \text { years } \\
0-4 \text { years of schooling }\end{array}$ & 300.46 & 0.039 & 0.088 & 0.138 & 0.406 & 0.079 & 0.067 \\
\hline $\begin{array}{c}25-34 \text { years } \\
5-8 \text { years of schooling }\end{array}$ & 435.64 & 0.056 & 0.076 & 0.194 & 0.482 & 0.143 & 0.109 \\
\hline $\begin{array}{c}25-34 \text { years } \\
9+\text { years of schooling }\end{array}$ & 796.27 & 0.102 & 0.081 & 0.296 & 0.563 & 0.196 & 0.206 \\
\hline $\begin{array}{c}35-49 \text { years } \\
0-4 \text { years of schooling }\end{array}$ & 400.16 & 0.051 & 0.133 & 0.348 & 0.696 & 0.296 & 0.265 \\
\hline $\begin{array}{c}35-49 \text { years } \\
5-8 \text { years of schooling }\end{array}$ & 610.31 & 0.078 & 0.067 & 0.426 & 0.764 & 0.460 & 0.361 \\
\hline $\begin{array}{c}35-49 \text { years } \\
9+\text { years of schooling }\end{array}$ & $1,375.81$ & 0.177 & 0.085 & 0.602 & 0.848 & 0.554 & 0.573 \\
\hline $\begin{array}{c}50-64 \text { years } \\
0-4 \text { years of schooling }\end{array}$ & 394.42 & 0.051 & 0.104 & 0.653 & 0.952 & 0.721 & 0.635 \\
\hline $\begin{array}{c}50-64 \text { years } \\
5-8 \text { years of schooling }\end{array}$ & 811.51 & 0.104 & 0.020 & 0.757 & 0.972 & 0.972 & 0.757 \\
\hline $\begin{array}{c}50-64 \text { years } \\
9+\text { years of schooling }\end{array}$ & $1,891.74$ & 0.243 & 0.028 & 1.000 & 1.000 & - & - \\
\hline Total & $7,791.57$ & 1.0 & 1.0 & - & - & 3.490 & 3.038 \\
\hline
\end{tabular}

Gini Coefficient $[\operatorname{sum}(\mathbf{f})-\operatorname{sum}(\mathrm{g})]=\quad \mathbf{0 . 4 5 2}$

\footnotetext{
${ }^{+}$Nominal income was converted to base 1 in January 2002, taking into account changes in currency and inflation.

Source: 1970-2000 Brazilian Censuses.
} 
Table 7.5. Gini Coefficient Calculation Using Predicted National Earnings ${ }^{+}$from Equation (1) and National Age-Education Distribution, and Maintaining the 1970 Age Distribution Constant, 2000.

\begin{tabular}{|c|c|c|c|c|c|c|c|}
\hline $\begin{array}{l}\text { Age-Education } \\
\text { Group }\end{array}$ & $\begin{array}{c}\text { Income } \\
\text { Table 7.1 } \\
\text { (column 3) }\end{array}$ & $\begin{array}{c}\text { Income } \\
\text { Distribution }\end{array}$ & $\begin{array}{l}\text { Age-Educ. } \\
\text { Distribution } \\
\text { (1970 Age) }\end{array}$ & $\begin{array}{l}\text { Cumulative } \\
\text { Income }\end{array}$ & $\begin{array}{c}\text { Cumulative } \\
\text { Age-Educ. } \\
\text { Distribution }\end{array}$ & $\left(\mathbf{e}_{\mathbf{i}}\right) *\left(\mathbf{d}_{\mathbf{i}+1}\right)$ & $\left(d_{i}\right) *\left(e_{i+1}\right)$ \\
\hline & (a) & (b) & (c) & (d) & (e) & (f) & (g) \\
\hline $\begin{array}{c}15-24 \text { years } \\
0-4 \text { years of schooling }\end{array}$ & 201.81 & 0.026 & 0.103 & 0.026 & 0.103 & 0.006 & 0.006 \\
\hline $\begin{array}{c}15-24 \text { years } \\
5-8 \text { years of schooling }\end{array}$ & 229.60 & 0.029 & 0.143 & 0.055 & 0.246 & 0.023 & 0.020 \\
\hline $\begin{array}{c}15-24 \text { years } \\
9+\text { years of schooling }\end{array}$ & 306.83 & 0.039 & 0.117 & 0.094 & 0.363 & 0.048 & 0.042 \\
\hline $\begin{array}{c}25-34 \text { years } \\
0-4 \text { years of schooling }\end{array}$ & 300.81 & 0.038 & 0.085 & 0.132 & 0.448 & 0.084 & 0.069 \\
\hline $\begin{array}{c}25-34 \text { years } \\
5-8 \text { years of schooling }\end{array}$ & 442.69 & 0.056 & 0.074 & 0.188 & 0.522 & 0.152 & 0.113 \\
\hline $\begin{array}{c}25-34 \text { years } \\
9+\text { years of schooling }\end{array}$ & 808.72 & 0.103 & 0.078 & 0.291 & 0.600 & 0.206 & 0.210 \\
\hline $\begin{array}{c}35-49 \text { years } \\
0-4 \text { years of schooling }\end{array}$ & 406.05 & 0.052 & 0.121 & 0.343 & 0.721 & 0.306 & 0.268 \\
\hline $\begin{array}{c}35-49 \text { years } \\
5-8 \text { years of schooling }\end{array}$ & 638.24 & 0.081 & 0.061 & 0.424 & 0.782 & 0.472 & 0.364 \\
\hline $\begin{array}{c}35-49 \text { years } \\
9+\text { years of schooling }\end{array}$ & $1,409.14$ & 0.179 & 0.077 & 0.603 & 0.859 & 0.562 & 0.576 \\
\hline $\begin{array}{c}50-64 \text { years } \\
0-4 \text { years of schooling }\end{array}$ & 399.25 & 0.051 & 0.096 & 0.654 & 0.955 & 0.725 & 0.637 \\
\hline $\begin{array}{c}50-64 \text { years } \\
5-8 \text { years of schooling }\end{array}$ & 830.70 & 0.106 & 0.018 & 0.759 & 0.974 & 0.974 & 0.759 \\
\hline $\begin{array}{c}50-64 \text { years } \\
\text { 9+ years of schooling }\end{array}$ & $1,892.67$ & 0.241 & 0.026 & 1.000 & 1.000 & - & - \\
\hline Total & $7,866.51$ & 1.0 & 1.0 & - & - & 3.557 & 3.064 \\
\hline
\end{tabular}

\section{Gini Coefficient $[\operatorname{sum}(f)-\operatorname{sum}(g)]=\quad 0.492$}

${ }^{+}$Nominal income was converted to base 1 in January 2002, taking into account changes in currency and inflation.

Source: 1970-2000 Brazilian Censuses. 
Table 7.6. Gini Coefficient Calculation Using Predicted National Earnings ${ }^{+}$from Equation (1) and National Age-Education Distribution, and Maintaining the 1970 Education Distribution Constant, 2000.

\begin{tabular}{|c|c|c|c|c|c|c|c|}
\hline \multirow[t]{2}{*}{$\begin{array}{l}\text { Age-Education } \\
\text { Group }\end{array}$} & $\begin{array}{c}\text { Income } \\
\text { Table 7.1 } \\
\text { (column 4) }\end{array}$ & $\begin{array}{c}\text { Income } \\
\text { Distribution }\end{array}$ & $\begin{array}{l}\text { Age-Educ. } \\
\text { Distribution } \\
\text { (1970 Educ.) }\end{array}$ & $\begin{array}{l}\text { Cumulative } \\
\text { Income }\end{array}$ & $\begin{array}{c}\text { Cumulative } \\
\text { Age-Educ. } \\
\text { Distribution }\end{array}$ & $\left(e_{i}\right)^{*}\left(d_{i+1}\right)$ & $\left(d_{i}\right) *\left(e_{i+1}\right)$ \\
\hline & (a) & (b) & (c) & (d) & (e) & (f) & (g) \\
\hline $\begin{array}{c}15-24 \text { years } \\
0-4 \text { years of schooling }\end{array}$ & 200.53 & 0.022 & 0.182 & 0.022 & 0.182 & 0.010 & 0.005 \\
\hline $\begin{array}{c}15-24 \text { years } \\
5-8 \text { years of schooling }\end{array}$ & 321.10 & 0.035 & 0.042 & 0.057 & 0.223 & 0.025 & 0.014 \\
\hline $\begin{array}{c}15-24 \text { years } \\
9+\text { years of schooling }\end{array}$ & 480.39 & 0.053 & 0.024 & 0.110 & 0.247 & 0.035 & 0.047 \\
\hline $\begin{array}{c}25-34 \text { years } \\
0-4 \text { years of schooling }\end{array}$ & 290.72 & 0.032 & 0.177 & 0.142 & 0.424 & 0.088 & 0.064 \\
\hline $\begin{array}{c}25-34 \text { years } \\
5-8 \text { years of schooling }\end{array}$ & 590.64 & 0.065 & 0.026 & 0.207 & 0.450 & 0.148 & 0.097 \\
\hline $\begin{array}{c}25-34 \text { years } \\
9+\text { years of schooling }\end{array}$ & $1,111.79$ & 0.122 & 0.019 & 0.329 & 0.469 & 0.172 & 0.242 \\
\hline $\begin{array}{c}35-49 \text { years } \\
0-4 \text { years of schooling }\end{array}$ & 341.30 & 0.038 & 0.267 & 0.367 & 0.736 & 0.338 & 0.278 \\
\hline $\begin{array}{c}35-49 \text { years } \\
5-8 \text { years of schooling }\end{array}$ & 843.60 & 0.093 & 0.023 & 0.459 & 0.759 & 0.489 & 0.358 \\
\hline $\begin{array}{c}35-49 \text { years } \\
9+\text { years of schooling }\end{array}$ & $1,679.37$ & 0.185 & 0.020 & 0.644 & 0.779 & 0.530 & 0.635 \\
\hline $\begin{array}{c}50-64 \text { years } \\
0-4 \text { years of schooling }\end{array}$ & 331.58 & 0.036 & 0.208 & 0.680 & 0.987 & 0.780 & 0.676 \\
\hline $\begin{array}{c}50-64 \text { years } \\
5-8 \text { years of schooling }\end{array}$ & $1,005.31$ & 0.110 & 0.007 & 0.791 & 0.993 & 0.993 & 0.791 \\
\hline $\begin{array}{c}50-64 \text { years } \\
9+\text { years of schooling }\end{array}$ & $1,901.83$ & 0.209 & 0.007 & 1.000 & 1.000 & - & - \\
\hline Total & 9,098.16 & 1.0 & 1.0 & - & - & 3.609 & 3.208 \\
\hline
\end{tabular}

\section{Gini Coefficient $[\operatorname{sum}(f)-\operatorname{sum}(g)]=\quad 0.401$}

${ }^{+}$Nominal income was converted to base 1 in January 2002, taking into account changes in currency and inflation.

Source: 1970-2000 Brazilian Censuses. 
Table 7.7. Gini Coefficient Calculation Using Predicted National Earnings ${ }^{+}$from Equation (1') and National Age-Education Distribution, 1970.

\begin{tabular}{|c|c|c|c|c|c|c|c|}
\hline $\begin{array}{l}\text { Age-Education } \\
\text { Group }\end{array}$ & $\begin{array}{c}\text { Income } \\
\text { Table 7.2 } \\
\text { (column 1) }\end{array}$ & $\begin{array}{c}\text { Income } \\
\text { Distribution }\end{array}$ & $\begin{array}{c}\text { Age-Educ. } \\
\text { Distribution } \\
\text { Table 5.1 } \\
\end{array}$ & $\begin{array}{l}\text { Cumulative } \\
\text { Income }\end{array}$ & $\begin{array}{l}\text { Cumulative } \\
\text { Age-Educ. } \\
\text { Distribution }\end{array}$ & $\left(e_{i}\right) *\left(d_{i+1}\right)$ & $\left(d_{i}\right) *\left(e_{i+1}\right)$ \\
\hline & (a) & (b) & (c) & (d) & (e) & (f) & (g) \\
\hline $\begin{array}{c}15-24 \text { years } \\
0-4 \text { years of schooling }\end{array}$ & 161.01 & 0.020 & 0.282 & 0.020 & 0.282 & 0.014 & 0.007 \\
\hline $\begin{array}{c}15-24 \text { years } \\
5-8 \text { years of schooling }\end{array}$ & 254.35 & 0.031 & 0.054 & 0.051 & 0.336 & 0.035 & 0.019 \\
\hline $\begin{array}{c}15-24 \text { years } \\
9+\text { years of schooling }\end{array}$ & 430.20 & 0.053 & 0.027 & 0.104 & 0.363 & 0.048 & 0.058 \\
\hline $\begin{array}{c}25-34 \text { years } \\
0-4 \text { years of schooling }\end{array}$ & 225.60 & 0.028 & 0.197 & 0.132 & 0.560 & 0.110 & 0.076 \\
\hline $\begin{array}{c}25-34 \text { years } \\
5-8 \text { years of schooling }\end{array}$ & 533.62 & 0.066 & 0.020 & 0.197 & 0.580 & 0.188 & 0.118 \\
\hline $\begin{array}{c}25-34 \text { years } \\
9+\text { years of schooling }\end{array}$ & $1,040.79$ & 0.128 & 0.020 & 0.325 & 0.600 & 0.215 & 0.269 \\
\hline $\begin{array}{c}35-49 \text { years } \\
0-4 \text { years of schooling }\end{array}$ & 269.80 & 0.033 & 0.227 & 0.358 & 0.827 & 0.376 & 0.302 \\
\hline $\begin{array}{c}35-49 \text { years } \\
5-8 \text { years of schooling }\end{array}$ & 788.13 & 0.097 & 0.016 & 0.455 & 0.843 & 0.542 & 0.391 \\
\hline $\begin{array}{c}35-49 \text { years } \\
9+\text { years of schooling }\end{array}$ & $1,536.64$ & 0.189 & 0.016 & 0.643 & 0.859 & 0.582 & 0.635 \\
\hline $\begin{array}{c}50-64 \text { years } \\
0-4 \text { years of schooling }\end{array}$ & 276.26 & 0.034 & 0.128 & 0.677 & 0.987 & 0.783 & 0.673 \\
\hline $\begin{array}{c}50-64 \text { years } \\
5-8 \text { years of schooling }\end{array}$ & 941.57 & 0.116 & 0.007 & 0.793 & 0.994 & 0.994 & 0.793 \\
\hline $\begin{array}{c}50-64 \text { years } \\
9+\text { years of schooling }\end{array}$ & $1,687.24$ & 0.207 & 0.006 & 1.000 & 1.000 & - & - \\
\hline Total & $8,145.21$ & 1.0 & 1.0 & - & - & 3.887 & 3.340 \\
\hline
\end{tabular}

Gini Coefficient $[\operatorname{sum}(\mathbf{f})-\operatorname{sum}(\mathrm{g})]=\quad 0.547$

\footnotetext{
${ }^{+}$Nominal income was converted to base 1 in January 2002, taking into account changes in currency and inflation.

Source: 1970-2000 Brazilian Censuses.
} 
Table 7.8. Gini Coefficient Calculation Using Predicted National Earnings ${ }^{+}$from Equation (1') and National Age-Education Distribution, 2000.

\begin{tabular}{|c|c|c|c|c|c|c|c|}
\hline $\begin{array}{l}\text { Age-Education } \\
\text { Group }\end{array}$ & $\begin{array}{c}\text { Income } \\
\text { Table 7.2 } \\
\text { (column 2) } \\
\end{array}$ & $\begin{array}{c}\text { Income } \\
\text { Distribution }\end{array}$ & $\begin{array}{c}\text { Age-Educ. } \\
\text { Distribution } \\
\text { Table 5.1 } \\
\end{array}$ & $\begin{array}{l}\text { Cumulative } \\
\text { Income }\end{array}$ & $\begin{array}{l}\text { Cumulative } \\
\text { Age-Educ. } \\
\text { Distribution }\end{array}$ & $\left(e_{i}\right) *\left(d_{i+1}\right)$ & $\left(\mathbf{d}_{\mathbf{i}}\right)^{*}\left(\mathbf{e}_{\mathbf{i}+1}\right)$ \\
\hline & (a) & (b) & (c) & (d) & (e) & (f) & (g) \\
\hline $\begin{array}{c}15-24 \text { years } \\
0-4 \text { years of schooling }\end{array}$ & 206.49 & 0.028 & 0.090 & 0.028 & 0.090 & 0.006 & 0.006 \\
\hline $\begin{array}{c}15-24 \text { years } \\
5-8 \text { years of schooling }\end{array}$ & 268.63 & 0.037 & 0.125 & 0.065 & 0.215 & 0.023 & 0.021 \\
\hline $\begin{array}{c}15-24 \text { years } \\
9+\text { years of schooling }\end{array}$ & 321.84 & 0.044 & 0.102 & 0.109 & 0.317 & 0.048 & 0.044 \\
\hline $\begin{array}{c}25-34 \text { years } \\
0-4 \text { years of schooling }\end{array}$ & 312.56 & 0.043 & 0.088 & 0.152 & 0.406 & 0.086 & 0.073 \\
\hline $\begin{array}{c}25-34 \text { years } \\
5-8 \text { years of schooling }\end{array}$ & 445.95 & 0.061 & 0.076 & 0.213 & 0.482 & 0.156 & 0.120 \\
\hline $\begin{array}{c}25-34 \text { years } \\
9+\text { years of schooling }\end{array}$ & 812.09 & 0.111 & 0.081 & 0.324 & 0.563 & 0.213 & 0.225 \\
\hline $\begin{array}{c}35-49 \text { years } \\
0-4 \text { years of schooling }\end{array}$ & 404.40 & 0.055 & 0.133 & 0.379 & 0.696 & 0.322 & 0.289 \\
\hline $\begin{array}{c}35-49 \text { years } \\
5-8 \text { years of schooling }\end{array}$ & 609.37 & 0.083 & 0.067 & 0.462 & 0.764 & 0.487 & 0.392 \\
\hline $\begin{array}{c}35-49 \text { years } \\
9+\text { years of schooling }\end{array}$ & $1,281.75$ & 0.175 & 0.085 & 0.637 & 0.848 & 0.589 & 0.607 \\
\hline $\begin{array}{c}50-64 \text { years } \\
0-4 \text { years of schooling }\end{array}$ & 414.27 & 0.057 & 0.104 & 0.694 & 0.952 & 0.767 & 0.674 \\
\hline $\begin{array}{c}50-64 \text { years } \\
5-8 \text { years of schooling }\end{array}$ & 814.89 & 0.111 & 0.020 & 0.805 & 0.972 & 0.972 & 0.805 \\
\hline $\begin{array}{c}50-64 \text { years } \\
9+\text { years of schooling }\end{array}$ & $1,422.78$ & 0.195 & 0.028 & 1.000 & 1.000 & - & - \\
\hline Total & 7,315.02 & 1.0 & 1.0 & - & - & 3.668 & 3.257 \\
\hline
\end{tabular}

Gini Coefficient $[\operatorname{sum}(\mathbf{f})-\operatorname{sum}(\mathrm{g})]=\quad \mathbf{0 . 4 1 1}$

\footnotetext{
${ }^{+}$Nominal income was converted to base 1 in January 2002, taking into account changes in currency and inflation.

Source: 1970-2000 Brazilian Censuses.
} 
Table 7.9. Gini Coefficient Calculation Using Predicted National Earnings ${ }^{+}$from Equation (1') and National Age-Education Distribution, and Maintaining the 1970 Age Distribution Constant, 2000.

\begin{tabular}{|c|c|c|c|c|c|c|c|}
\hline $\begin{array}{l}\text { Age-Education } \\
\text { Group }\end{array}$ & $\begin{array}{c}\text { Income } \\
\text { Table 7.2 } \\
\text { (column 3) }\end{array}$ & $\begin{array}{c}\text { Income } \\
\text { Distribution }\end{array}$ & $\begin{array}{l}\text { Age-Educ. } \\
\text { Distribution } \\
\text { (1970 Age) }\end{array}$ & $\begin{array}{l}\text { Cumulative } \\
\text { Income }\end{array}$ & $\begin{array}{c}\text { Cumulative } \\
\text { Age-Educ. } \\
\text { Distribution }\end{array}$ & $\left(\mathbf{e}_{\mathbf{i}}\right) *\left(\mathbf{d}_{\mathbf{i}+1}\right)$ & $\left(\mathbf{d}_{\mathbf{i}}\right)^{*}\left(\mathbf{e}_{\mathbf{i}+1}\right)$ \\
\hline & (a) & (b) & (c) & (d) & (e) & (f) & (g) \\
\hline $\begin{array}{c}15-24 \text { years } \\
0-4 \text { years of schooling }\end{array}$ & 204.45 & 0.027 & 0.103 & 0.027 & 0.103 & 0.006 & 0.007 \\
\hline $\begin{array}{c}15-24 \text { years } \\
5-8 \text { years of schooling }\end{array}$ & 245.19 & 0.033 & 0.143 & 0.060 & 0.246 & 0.025 & 0.022 \\
\hline $\begin{array}{c}15-24 \text { years } \\
9+\text { years of schooling }\end{array}$ & 299.68 & 0.040 & 0.117 & 0.101 & 0.363 & 0.052 & 0.045 \\
\hline $\begin{array}{c}25-34 \text { years } \\
0-4 \text { years of schooling }\end{array}$ & 314.13 & 0.042 & 0.085 & 0.143 & 0.448 & 0.091 & 0.075 \\
\hline $\begin{array}{c}25-34 \text { years } \\
5-8 \text { years of schooling }\end{array}$ & 454.15 & 0.061 & 0.074 & 0.204 & 0.522 & 0.164 & 0.122 \\
\hline $\begin{array}{c}25-34 \text { years } \\
9+\text { years of schooling }\end{array}$ & 815.46 & 0.110 & 0.078 & 0.314 & 0.600 & 0.222 & 0.226 \\
\hline $\begin{array}{c}35-49 \text { years } \\
0-4 \text { years of schooling }\end{array}$ & 414.40 & 0.056 & 0.121 & 0.369 & 0.721 & 0.329 & 0.289 \\
\hline $\begin{array}{c}35-49 \text { years } \\
5-8 \text { years of schooling }\end{array}$ & 642.95 & 0.086 & 0.061 & 0.456 & 0.782 & 0.496 & 0.391 \\
\hline $\begin{array}{c}35-49 \text { years } \\
9+\text { years of schooling }\end{array}$ & $1,328.73$ & 0.179 & 0.077 & 0.634 & 0.859 & 0.594 & 0.606 \\
\hline $\begin{array}{c}50-64 \text { years } \\
0-4 \text { years of schooling }\end{array}$ & 424.84 & 0.057 & 0.096 & 0.692 & 0.955 & 0.766 & 0.673 \\
\hline $\begin{array}{c}50-64 \text { years } \\
5-8 \text { years of schooling }\end{array}$ & 825.19 & 0.111 & 0.018 & 0.802 & 0.974 & 0.974 & 0.802 \\
\hline $\begin{array}{c}50-64 \text { years } \\
9+\text { years of schooling }\end{array}$ & $1,469.16$ & 0.198 & 0.026 & 1.000 & 1.000 & - & - \\
\hline Total & 7,438.31 & 1.0 & 1.0 & - & - & 3.719 & 3.259 \\
\hline
\end{tabular}

\section{Gini Coefficient $[\operatorname{sum}(f)-\operatorname{sum}(g)]=\quad 0.459$}

${ }^{+}$Nominal income was converted to base 1 in January 2002, taking into account changes in currency and inflation.

Source: 1970-2000 Brazilian Censuses. 
Table 7.10. Gini Coefficient Calculation Using Predicted National Earnings ${ }^{+}$from Equation (1') and National Age-Education Distribution, and Maintaining the 1970 Education Distribution Constant, 2000.

\begin{tabular}{|c|c|c|c|c|c|c|c|}
\hline $\begin{array}{l}\text { Age-Education } \\
\text { Group }\end{array}$ & $\begin{array}{c}\text { Income } \\
\text { Table } 7.2 \\
\text { (column 4) }\end{array}$ & $\begin{array}{c}\text { Income } \\
\text { Distribution }\end{array}$ & $\begin{array}{c}\text { Age-Educ. } \\
\text { Distribution } \\
\text { (1970 Educ.) }\end{array}$ & $\begin{array}{l}\text { Cumulative } \\
\text { Income }\end{array}$ & $\begin{array}{c}\text { Cumulative } \\
\text { Age-Educ. } \\
\text { Distribution }\end{array}$ & $\left(\mathbf{e}_{i}\right)^{*}\left(d_{i+1}\right)$ & $\left(\mathbf{d}_{\mathbf{i}}\right)^{*}\left(\mathbf{e}_{\mathbf{i}+1}\right)$ \\
\hline & (a) & (b) & (c) & (d) & (e) & (f) & (g) \\
\hline $\begin{array}{c}15-24 \text { years } \\
0-4 \text { years of schooling }\end{array}$ & 192.58 & 0.021 & 0.182 & 0.021 & 0.182 & 0.012 & 0.005 \\
\hline $\begin{array}{c}15-24 \text { years } \\
5-8 \text { years of schooling }\end{array}$ & 409.39 & 0.045 & 0.042 & 0.067 & 0.223 & 0.027 & 0.017 \\
\hline $\begin{array}{c}15-24 \text { years } \\
9+\text { years of schooling }\end{array}$ & 469.45 & 0.052 & 0.024 & 0.119 & 0.247 & 0.037 & 0.050 \\
\hline $\begin{array}{c}25-34 \text { years } \\
0-4 \text { years of schooling }\end{array}$ & 271.04 & 0.030 & 0.177 & 0.149 & 0.424 & 0.093 & 0.067 \\
\hline $\begin{array}{c}25-34 \text { years } \\
5-8 \text { years of schooling }\end{array}$ & 629.99 & 0.070 & 0.026 & 0.219 & 0.450 & 0.143 & 0.103 \\
\hline $\begin{array}{c}25-34 \text { years } \\
9+\text { years of schooling }\end{array}$ & 887.72 & 0.098 & 0.019 & 0.317 & 0.469 & 0.165 & 0.234 \\
\hline $\begin{array}{c}35-49 \text { years } \\
0-4 \text { years of schooling }\end{array}$ & 310.07 & 0.034 & 0.267 & 0.352 & 0.736 & 0.332 & 0.267 \\
\hline $\begin{array}{c}35-49 \text { years } \\
5-8 \text { years of schooling }\end{array}$ & 898.28 & 0.100 & 0.023 & 0.451 & 0.759 & 0.488 & 0.351 \\
\hline $\begin{array}{c}35-49 \text { years } \\
9+\text { years of schooling }\end{array}$ & $1,729.86$ & 0.192 & 0.020 & 0.643 & 0.779 & 0.526 & 0.635 \\
\hline $\begin{array}{c}50-64 \text { years } \\
0-4 \text { years of schooling }\end{array}$ & 289.37 & 0.032 & 0.208 & 0.675 & 0.987 & 0.766 & 0.671 \\
\hline $\begin{array}{c}50-64 \text { years } \\
5-8 \text { years of schooling }\end{array}$ & 914.27 & 0.101 & 0.007 & 0.777 & 0.993 & 0.993 & 0.777 \\
\hline $\begin{array}{c}50-64 \text { years } \\
9+\text { years of schooling }\end{array}$ & $2,013.55$ & 0.223 & 0.007 & 1.000 & 1.000 & - & - \\
\hline Total & $9,015.57$ & 1.0 & 1.0 & - & - & 3.582 & 3.175 \\
\hline
\end{tabular}

\section{Gini Coefficient $[\operatorname{sum}(f)-\operatorname{sum}(g)]=\quad 0.407$}

${ }^{+}$Nominal income was converted to base 1 in January 2002, taking into account changes in currency and inflation.

Source: 1970-2000 Brazilian Censuses. 
Table 7.11 summarizes all Gini coefficients estimated above. These results indicate that the income inequality decreased from 1970 to 2000 among the 12 age-education groups. If the age composition had remained the same from 1970 to 2000, the income inequality would have experienced a smaller decrease than the one observed when both age and education changed over time. In the case of education composition constant from 1970 to 2000 , the income inequality would have decreased even more in the period. These numbers show that population aging had an important impact in the reduction of inequality in Brazil. Moreover, the improvement in education attainment avoided even further declines in income inequality in the country. Thus, public policies have to take into account that improvement in education attainment is necessary in order for workers to have better returns in earnings, but changes in the labor force age structure are also necessary to generate a more equal income distribution. Finally, family planning programs are essential in the reduction of inequality in Brazil, because they would decrease the proportion of younger workers entering the labor market in future years.

Table 7.11. Summary of Gini Coefficients Using Predicted National Earnings from Equations (1) and (1') and National Age-Education Distributions, 1970 and 2000 .

\begin{tabular}{|c|c|c|c|c|}
\hline \multirow[t]{2}{*}{ Models } & \multicolumn{4}{|c|}{ Gini Coefficients Using National Distribution from: } \\
\hline & 1970 & 2000 & $\begin{array}{c}1970 \text { Age; } \\
2000 \text { Education }\end{array}$ & $\begin{array}{l}1970 \text { Education; } \\
2000 \text { Age }\end{array}$ \\
\hline $\begin{array}{l}\text { Equation (1): } \\
\text { Own-effects }\end{array}$ & 0.542 & 0.452 & 0.492 & 0.401 \\
\hline $\begin{array}{c}\text { Equation (1'): } \\
\text { Own-effects X Year }\end{array}$ & 0.547 & 0.411 & 0.459 & 0.407 \\
\hline
\end{tabular}

Source: 1970-2000 Brazilian Censuses. 
An important aspect of the Brazilian economy that has to be taken into account for public policies is related to the differences in the male population distribution in ageeducation groups by race. The 1970 Census does not have information on color or race characteristics of respondents. The 1980 Census has the variable "color" (cor) with categories "white" (branca), "black" (preta), "yellow" (amarela - Asian), and "brown" (parda). The 1991 and 2000 Censuses added the category "indigenous" (indigena) to the ones available in the 1980 Census, and identify the variable as "color or race" (cor ou raça). Here this variable will be denominated as race.

Wood and Carvalho (1994) and Carvalho et al (2003) indicated that the brown category had a growth over time above the expected vegetative growth. They suspect that because the black population experienced economic improvement through the years, and due to the stereotype of poverty associated to the black race, they might have identified themselves as brown. Moreover, the black identification seems to be increasing in recent years, perhaps due to the ideological work done by black civil equality movements in the 1990s. Further, maybe due to the decline in the stereotype of being brown, people who identified themselves as white in the past are now classifying their race as brown. Because of the instability in the race classification over time, brown and black categories are usually aggregated in one single category. This aggregation is called "non-white" in this study. People classified as yellow or indigenous are not included in the following analysis, because they constitute a small proportion in the population. Among males between 15 and 64 years of age, only 0.69 percent were classified as yellow in 1980, 0.50 in 1991 and 0.49 in 2000. The indigenous group varied from 0.18 percent in 1991 to 0.42 percent in 2000 , indicating that this group might also have problems with self-identification.

Table 7.12 presents the male population distribution by age-education group and race from 1980 to 2000. Such as in Table 5.1, the proportion of males in the lowest 156 
education group (zero to four years of schooling) has been decreasing over time, and the proportion in the other groups have been increasing over time. Further, the distribution by race illustrates that there is a higher proportion of non-white population in the lowest education group, for all age groups, compared to the white population. Related to this pattern, the proportion of white population is bigger in the groups with five to eight years of schooling and at least nine years of schooling, compared to non-whites.

Table 7.13 gives an idea about the mean real monthly earnings of the male population by age-education group and race from 1980 to 2000. Such as in Table 3.3, levels and patterns of mean earnings might be influenced by drastic variations among individuals, within each age-education group. However, even with this limitation, Table 7.13 is a tool which provides an idea about earnings differences between non-whites and whites. In all age-education groups for all Censuses, earnings for white males are greater than the ones observed for black males.

Analyzing Tables 7.12 and 7.13 in conjunction with the findings presented in this study, one might say that public policies would have to take into account that changes in the age-education composition has been occurring in different levels for non-whites compared to whites. Policies would then have to target groups that are experiencing slower fertility decline, slower improvements in educational attainment, as well as lower earnings — the non-whites. Finally, as suggested by the differences across areas in the country, such policies should concentrate their effort on the non-whites living in areas with slower transitions in age-education structure. 
Table 7.12. Percent of Male Population by Year, Race, and Age-Education Group, 19802000.

\begin{tabular}{|c|c|c|c|c|c|c|}
\hline \multirow{2}{*}{$\begin{array}{l}\text { Age-education } \\
\text { Group }\end{array}$} & \multicolumn{2}{|c|}{1980} & \multicolumn{2}{|c|}{1991} & \multicolumn{2}{|c|}{2000} \\
\hline & $\begin{array}{l}\text { Non- } \\
\text { White }\end{array}$ & White & $\begin{array}{l}\text { Non- } \\
\text { White }\end{array}$ & White & $\begin{array}{l}\text { Non- } \\
\text { White }\end{array}$ & White \\
\hline $\begin{array}{c}15-24 \text { years } \\
0-4 \text { years of schooling }\end{array}$ & 26.87 & 15.98 & 19.93 & 9.77 & 12.99 & 5.60 \\
\hline $\begin{array}{c}15-24 \text { years } \\
5-8 \text { years of schooling }\end{array}$ & 9.07 & 11.68 & 11.82 & 12.44 & 13.74 & 11.41 \\
\hline $\begin{array}{c}15-24 \text { years } \\
9+\text { years of schooling }\end{array}$ & 3.00 & 7.93 & 3.96 & 7.77 & 7.47 & 12.62 \\
\hline $\begin{array}{c}25-34 \text { years } \\
0-4 \text { years of schooling }\end{array}$ & 18.96 & 14.55 & 15.16 & 9.93 & 11.36 & 6.64 \\
\hline $\begin{array}{c}25-34 \text { years } \\
5-8 \text { years of schooling }\end{array}$ & 3.20 & 4.42 & 6.32 & 7.35 & 7.80 & 7.53 \\
\hline $\begin{array}{c}25-34 \text { years } \\
9+\text { years of schooling }\end{array}$ & 2.33 & 6.49 & 4.66 & 9.86 & 5.89 & 10.02 \\
\hline $\begin{array}{c}35-49 \text { years } \\
0-4 \text { years of schooling }\end{array}$ & 21.06 & 17.54 & 19.02 & 15.43 & 15.68 & 11.36 \\
\hline $\begin{array}{c}35-49 \text { years } \\
5-8 \text { years of schooling }\end{array}$ & 1.63 & 2.93 & 3.06 & 4.22 & 6.21 & 7.22 \\
\hline $\begin{array}{c}35-49 \text { years } \\
9+\text { years of schooling }\end{array}$ & 1.08 & 4.08 & 2.96 & 7.76 & 5.15 & 11.22 \\
\hline $\begin{array}{c}50-64 \text { years } \\
0-4 \text { years of schooling }\end{array}$ & 12.07 & 11.48 & 11.67 & 11.33 & 10.80 & 9.99 \\
\hline $\begin{array}{c}50-64 \text { years } \\
5-8 \text { years of schooling }\end{array}$ & 0.47 & 1.28 & 0.78 & 1.50 & 1.60 & 2.32 \\
\hline $\begin{array}{c}50-64 \text { years } \\
9+\text { years of schooling }\end{array}$ & 0.26 & 1.63 & 0.67 & 2.62 & 1.32 & 4.06 \\
\hline Total & $13,969,010$ & $18,294,096$ & $20,551,988$ & $22,446,044$ & $24,182,946$ & $28,176,560$ \\
\hline
\end{tabular}


Table 7.13. Mean Real Monthly Earnings of Male Population by Year, Race, and AgeEducation Group, 1980-2000.

\begin{tabular}{|c|c|c|c|c|c|c|}
\hline \multirow{2}{*}{$\begin{array}{l}\text { Age-education } \\
\text { Group }\end{array}$} & \multicolumn{2}{|c|}{1980} & \multicolumn{2}{|c|}{1991} & \multicolumn{2}{|c|}{2000} \\
\hline & $\begin{array}{l}\text { Non- } \\
\text { White }\end{array}$ & White & $\begin{array}{l}\text { Non- } \\
\text { White }\end{array}$ & White & $\begin{array}{l}\text { Non- } \\
\text { White }\end{array}$ & White \\
\hline $\begin{array}{c}15-24 \text { years } \\
0-4 \text { years of schooling }\end{array}$ & 282.94 & 360.77 & 194.17 & 253.82 & 201.80 & 265.01 \\
\hline $\begin{array}{c}15-24 \text { years } \\
5-8 \text { years of schooling }\end{array}$ & 392.69 & 464.48 & 297.25 & 370.56 & 268.65 & 334.36 \\
\hline $\begin{array}{c}15-24 \text { years } \\
9+\text { years of schooling }\end{array}$ & 610.86 & 794.27 & 451.21 & 626.01 & 387.03 & 533.69 \\
\hline $\begin{array}{c}25-34 \text { years } \\
0-4 \text { years of schooling }\end{array}$ & 438.47 & 637.92 & 294.35 & 417.23 & 298.74 & 409.67 \\
\hline $\begin{array}{c}25-34 \text { years } \\
5-8 \text { years of schooling }\end{array}$ & 767.17 & $1,060.20$ & 490.09 & 652.96 & 465.18 & 619.49 \\
\hline $\begin{array}{c}25-34 \text { years } \\
9+\text { years of schooling }\end{array}$ & $1,320.87$ & $2,165.86$ & 863.60 & $1,390.95$ & 779.24 & $1,327.54$ \\
\hline $\begin{array}{c}35-49 \text { years } \\
0-4 \text { years of schooling }\end{array}$ & 487.97 & 826.58 & 368.88 & 587.85 & 376.62 & 570.53 \\
\hline $\begin{array}{c}35-49 \text { years } \\
5-8 \text { years of schooling }\end{array}$ & $1,061.73$ & $1,654.57$ & 712.56 & $1,034.82$ & 621.95 & 889.83 \\
\hline $\begin{array}{c}35-49 \text { years } \\
9+\text { years of schooling }\end{array}$ & $2,059.90$ & $3,535.43$ & $1,442.33$ & $2,409.82$ & $1,311.60$ & $2,328.44$ \\
\hline $\begin{array}{c}50-64 \text { years } \\
0-4 \text { years of schooling }\end{array}$ & 440.25 & 804.08 & 330.03 & 581.17 & 380.09 & 649.22 \\
\hline $\begin{array}{c}50-64 \text { years } \\
5-8 \text { years of schooling }\end{array}$ & $1,134.47$ & $1,911.23$ & 778.03 & $1,288.33$ & 698.79 & $1,232.89$ \\
\hline $\begin{array}{c}50-64 \text { years } \\
9+\text { years of schooling }\end{array}$ & $2,301.26$ & $3,935.86$ & $1,846.48$ & $3,037.60$ & $1,717.11$ & $3,325.95$ \\
\hline Total & 490.89 & $1,023.34$ & 418.37 & 873.96 & 484.31 & $1,025.90$ \\
\hline
\end{tabular}

${ }^{+}$Nominal income was converted to base 1 in January 2002, taking into account changes in currency and inflation. Source: 1980-2000 Brazilian Censuses. 


\section{Chapter 8. Conclusions}

In this study an old question has been tackled, but in a different context and with a different way of extracting lessons from the data. Interesting and important results concerning the effects of shifts in the age distribution of the working age population have been obtained by a number of authors by looking at this question within the context of the baby-boom generation's impact on the earnings of different cohorts in the United States. But the question has received little attention in the context of the countries of Asia and Latin America, which are now experiencing substantial shifts in their age distributions due to large and rapid declines in fertility. In these countries, the shifts in the age distribution have also been accompanied by dramatic increases in educational attainment that one might expect would also alter earnings distributions. A major difference between the United States and Latin American countries, such as Brazil, is in the magnitude of regional differences in the timing of both the educational and demographic transitions. These changes were fairly homogeneous across United States, but have had enormous variation geographically in Brazil. This heterogeneity both motivates and enhances the value of the regional approach to the problem that was undertaken in this study.

The first and most important result here is that relative group size matters. The ownquantity wage effects are generally negative, as predicted by factor-demand theory; and potential biases induced by a number of effects for which adjustments could not be made mean that, if anything, the true impacts of changing relative quantities are even larger in absolute value than the estimates suggested here. The results imply that workers classified by age-education group are not perfect substitutes, so that own cohort-education size generally depresses earnings. That the effects increase with education is consistent with the observation (Hamermesh 1993, chapter 3) of lower own-wage elasticities as education 
increases. Also, while there may have been shifts in relative demand over the 30 -year time span that was examined, unlike in the United States, they do not appear to have been large enough to offset the effects of variations in relative supply.

The effects of biased technological change and/or institutional changes are suggested by the evidence generated by the models that allowed the technological parameters to change over time. Most of the parameters became less negative over time, suggesting that more recent changes in relative supply have altered relative wages less than would have been the case in the 1970s. Indeed, the own-quantity effect for the least-skilled group — workers with 0-4 years of schooling — is essentially zero, suggesting that the increasing relative scarcity of such workers is no longer contributing to an increase in the relative earnings of the (fewer) remaining workers in the group. The results also suggest that throughout the period the sharp changes in the relative supply of the most skilled workers have reduced relative wages in this group: Accounting for relative shifts in supply, implies that wage inequality may have risen less than if these substitution effects had not occurred.

With respect to the central issue of the demographic dividend in developing economies, it was clarified from the outset that a related but different question is addressed in this study. The main focus in the dividend literature has been on changes in the dependency ratio. In countries such as Brazil, this ratio is undergoing dramatic change and will continue to do so for several decades. It is also true, however, that in terms of both age and educational attainment the composition of the Brazilian labor force, and labor forces in developing countries generally, is undergoing dramatic shifts. What has been investigated here, is whether these compositional shifts have had effects beyond those that are normally analyzed in the dividend literature using Mincerian earnings equations, and whether studying their role in the context of a formal theory of labor demand is worthwhile. 
Results suggest that shifts in the demographic and skill structure of the labor force are indeed influential and that this approach represents a fruitful way of expanding the study of this central problem in economic development. 


\section{References}

Alves, J.E.D. 2004. “O Bônus Demográfico e o Crescimento Econômico no Brasil.” Manuscript.

Autor, D., L. Katz, and A. Krueger. 1998. "Computing Inequality: Have Computers Changed the Labor Market?” Quarterly Journal of Economics, 93: 1169-1214.

Berger, M. 1985. "The Effect of Cohort Size on Earnings Growth: A Reexamination of the Evidence." The Journal of Political Economy, 93, 3: 561-573.

Bloom, D., R. Freeman, and S. Korenman. 1987. "The Labour-Market Consequences of Generational Crowding." European Journal of Population, 3: 131-176.

Bloom, D.E, D. Canning, and J. Sevilla. 2003. The Demographic Dividend: A New Perspective on the Economic Consequences of Population Change. Santa Monica, C.A.: RAND.

Bloom, D.E., and J. Williamson. 1998. "Demographic Transitions and Economic Miracles in Emerging Asia." World Bank Economics Review, 12: 419-456.

Bloom, D.E., and R.B. Freeman. 1986. "The Effects of Rapid Population Growth on Labor Supply and Employment in Developing Countries." Population and Development Review, 12, 3: 381-414.

Bloom, D.E., D. Canning, and P.N. Malaney. 2000. "Population Dynamics and Economic Growth in Asia." Population and Development Review, 26, Supplement: 257-290.

Borjas, G., R. Freeman, and L. Katz. 1997. "How Do Immigration and Trade Affect Labor Market Outcomes?” Brookings Papers on Economic Activity, 1997: 1-90.

Borjas, G.J. 2003. "The Labor Demand Curve is Downward Sloping: Reexamining the Impact of Immigration on the Labor Market." The Quarterly Journal of Economics, November: $1335-1374$.

Caetano, A.J. 2003. "Variáveis de Migração, Raça/Cor, Religião e Deficiências Mental e Físicas: Censos de 1960, 1970, 1980 1991, 2000.” IPUMS Technical Report Migration Characteristics.

Cahur, P., and A. Zylberberg. 2004. Labor Economics. Cambridge, MA: The MIT Press.

Carvalho, J.A.M., and L. Wong. 1999. "Demographic and Socioeconomic Implications of the Rapid Fertility Decline in Brazil: a Window of Opportunity." In: Reproductive 
Change in India and Brazil (G. Martine, M. Gupta, and L. Chen, ed.), pp. 208-239. Oxford: Oxford University Press.

Carvalho, J.A.M., and R.A. Garcia. 2003. "The Aging Process in the Brazilian Population: a Demographic Approach.” Cadernos de Saúde Pública, Rio de Janeiro, 19, 3: 725733.

Carvalho, J.A.M, C.H. Wood, and F.C.D Andrade. 2003. "Notas Acerca das Categorias de Cor dos Censos e Sobre a Classificação Subjetiva de Cor no Brasil: 1980/90.” Revista Brasileira de Estudos de População, 20, 1: 29-42.

Coale, A.J., and E.M. Hoover. 1958. Population Growth and Economic Development in Low-Income Countries. Princeton, NJ: Princeton University Press.

Corseuil, C.H., and M.N. Foguel. 2002. "Uma Sugestão de Deflatores para Rendas Obtidas a Partir de Algumas Pesquisas Domiciliares do IBGE.” Texto para Discussão, 897. Rio de Janeiro, RJ: Instituto de Pesquisa Econômica Aplicada (IPEA).

Easterlin, R.A. 1978. "What Will 1984 Be Like? Socioeconomic Implications of Recent Twists in Age Structure.” Demography, 15, 4: 397-432.

Freeman, R.B. 1979. "The Effect of Demographic Factors on Age-Earnings Profiles." The Journal of Human Resources, 14, 3: 289-318.

Gindling, T., and D. Robbins. 2001. "Patterns and Sources of Changing Wage Inequality in Chile and Costa Rica During Structural Adjustment." World Development, 29: 725-7245.

Grant, J., and D. Hamermesh. 1981. "Labor Market Competition Among Youths, White Women and Others," Review of Economics and Statistics, 63: 354-360.

Greenwood, M.J. 2007. "Modeling the Age and Age Composition of Late 19th Century U.S. Immigrants From Europe.” Explorations in Economic History, 44: 255-269.

Greenwood, M.J., and D. Sweetland. 1972. "The Determinants of Migration Between Standard Metropolitan Statistical Areas.” Demography, 9, 4: 665-681.

Greenwood, M.J., G.L. Hunt, D.S. Rickman, and G.I. Treyz. 1991. "Migration, Regional Equilibrium, and the Estimation of Compensating Differentials." The American Economic Review, 81, 5: 1382-1390.

Greenwood, M.J., J.M. McDowell, D.M. Waldman, and S.S. Zahniser. 1999. "The Influence of Social Programs in Source Countries on Various Classes of U.S. Immigration.” Journal of the American Statistical Association, 94, 445: 64-74. 
Greenwood, M.J., J.M. McDowell, M. Wierman. 2003. "Source-Country Social Programs and the Age Composition of Legal US Immigrants." Journal of Public Economics, 87: 739-771.

Hamermesh, D. 1986. "The Demand for Labor in the Long Run." In: Handbook of Labor Economics (O. Ashenfelter and R. Layard, eds.), pp.429-471. Amsterdam: NorthHolland Press.

Hamermesh, D. 1993. Labor Demand. Princeton, NJ: Princeton University Press.

Higgins, M., and J.G. Williamson. 1997. "Age Structure Dynamics in Asia and Dependence on Foreign Capital." Population and Development Review, 23, 2: 261293.

IBGE. 1999a. "Evolução e Perspectivas da Mortalidade Infantil no Brasil." Estudos e Pesquisas, Informação Demográfica e Socioeconômica, 2. Rio de Janeiro, RJ: Instituto Brasileiro de Geografia e Estatística (IBGE), Ministério do Planejamento, Orçamento e Gestão.

IBGE. 1999b. Estatísticas do Século XX. Rio de Janeiro, RJ: Instituto Brasileiro de Geografia e Estatística (IBGE), Ministério do Planejamento, Orçamento e Gestão. Table 2.15.

Jannuzzi, P.M. 2003. “O Levantamento das Características Econômicas da População nos Censos Demográficos Brasileiros de 1960 a 2000." IPUMS Technical Report Economic Characteristics.

Katz, L., and K. Murphy. 1992. "Changes in Relative Wages, 1963-1987: Supply and Demand Factors.” The Quarterly Journal of Economics, 107, 1: 35-78.

Kelley, A.C. 2003. "The Population Debate in Historical Perspective: Revisionism Revised." In: Population Matters (N. Birdsall, A.C. Kelley, and S.W. Sinding, eds.), pp. 24-54. Oxford: Oxford University Press.

Macunovich, D.J. 1998. "Fertility and the Easterlin Hypothesis: An Assessment of the Literature." Journal of Population Economics, 11: 53-111.

Malthus, T.K. 1798. An Essay on the Principle of Population. Harmondsworth, Middlesex, UK: Penguin Classics (1985 edition).

Martine, G., J.A.M. Carvalho, and A.R. Arias. 1994. "Mudanças Recentes no Padrão Demográfico Brasileiro e Implicações para a Agenda Social." Texto para Discussão, 345. Rio de Janeiro, RJ: Instituto de Pesquisa Econômica Aplicada (IPEA). 
Mason, A. 2005. "Demographic Transition and Demographic Dividends in Developed and Developing Countries." Population Division, Department of Economic and Social Affairs, United Nations. UN/POP/PD/2005/2.

Mason, A., W. Feng. 2005. "Demographic Dividends and China's Post Reform Economy." Paper presented at the XXV IUSSP General Population Conference. Tours, France, 18-23 July.

McKenzie, G. 1977. Complementarity, Substitutability, and Independence. Oxford Economic Papers, New Series, 29, 3: 430-441.

Mincer, J. 1974. Schooling, Experience, and Earnings. National Bureau of Economic Research: New York.

Moreira, M.M. 2001. "Structural Changes in the Brazilian Age Distribution: 1950-2050." Paper presented at the XXIV IUSSP General Population Conference. Salvador, Brazil, 18-24 August.

Pampel, F.C., and H.E. Peters. 1995. "The Easterlin Effect." Annual Review of Sociology, 21: $163-194$.

Pearce, I.F. 1964. A Contribution to Demand Analysis. London: Oxford University Press.

Perloff, Jeffrey M. 2006. Microeconomics (4th edition). Boston, MA: Addison Wesley.

Potter, J.E., C.P. Schmertmann, and S.M. Cavenaghi. 2002. "Fertility and Development: Evidence From Brazil.” Demography, 39: 739-761.

Riani, J.L.R. 2005. "Determinantes do Resultado Educacional no Brasil: Família, Perfil Escolar dos Municípios e Dividendo Demográfico numa Abordagem Hierárquica e Espacial.” Ph.D. Dissertation. Belo Horizonte, MG: Centro de Desenvolvimento e Planejamento Regional (CEDEPLAR/UFMG).

Rios-Neto, E.L.G. 2005. "Questões Emergentes na Demografia Brasileira." Textos para Discussão, 276. Belo Horizonte, MG: Centro de Desenvolvimento e Planejamento Regional (CEDEPLAR/UFMG).

Roberts, M., and E. Skoufias. 1997. "The Long-Run Demand for Skilled and Unskilled Labor in Colombian Manufacturing Plants." Review of Economics and Statistics, 79: 330-334.

Rogers, A., and L. Jordan. 2004. "Estimating Migration Flows From Birthplace-Specific Population Stocks of Infants." Geographical Analysis, 36, 1: 38-53. 
Saavedra, J., and M. Torero. 2004. "Labor Market Reforms and Their Impact over Formal Labor Demand and Job Market Turnover: The Case of Peru." In: Law and Employment: Lessons From Latin America and the Caribbean. (J. Heckman and C. Pagés, eds.). Chicago: University of Chicago Press, 131-182.

Shephard, R.W. 1953. Cost and Production Functions. Princeton, NJ: Princeton University Press.

Shephard, R.W. 1970. Theory of Cost and Production Functions. Princeton, NJ: Princeton University Press.

Triest, R.K., M. Sapozhnikov, and S.A. Sass. 2006. "Population Aging and the Structure of Wages." Chestnut Hill, MA: Center for Retirement Research at Boston College.

Welch, F. 1979. "Effects of Cohort Size on Earnings: The Baby Boom Babies' Financial Bust." The Journal of Political Economy, 87, 5, 2: S65-S97.

Williamson, J.G.. 2003. "Demographic Change, Economic Growth, and Inequality." In: Population Matters (N. Birdsall, A.C. Kelley, and S.W. Sinding, eds.). Oxford: Oxford University Press, 106-136.

Wong, L., and J.A.M. Carvalho. 2005. "Demographic Bonuses and Challenges of the Age Structural Transition in Brazil." Paper presented at the XXV IUSSP General Population Conference. Tours, France, 18-23 July.

Wood, C.H, J.A.M. Carvalho. 1994. "Categorias do Censo e Classificação Subjetiva de Cor no Brasil." Revista Brasileira de Estudos de População, 11, 1: 3-17.

World Bank. 2004. World Economic Outlook: a Survey by the Staff of the International Monetary Fund. Washington, D.C.: International Monetary Fund. 


\section{Vita}

Ernesto Friedrich de Lima Amaral was born in Goiânia, Goiás, Brazil on March 18, 1977, the son of José Reinaldo do Amaral and Lenir Miguel de Lima. He attended primary and secondary schooling at "Escola Pequeno Príncipe", "Rudá - Centro Cenecista de Educação", and "Colégio de Aplicação - Cepae", Goiânia, Goiás, Brazil. In February 2000, he received his Bachelor of Arts degree in Social Sciences from the Federal University of Goiás, Brazil. In May 2002, he received a Master of Arts degree in Demography from the Federal University of Minas Gerais, Brazil. In August 2002 he entered the Graduate School at the University of Texas at Austin.

This dissertation was typed by the author. 